Csetnek Tünde Tímea

A társadalmi tőke fejlődése a magyar-román határ menti övezetben 


\section{Politikatudományi Tanszék}

\section{Témavezetők:}

Dr. Jenei György, DSc. egyetemi tanár, BCE

Dr.Hajnal György, Egyetemi docens, BCE 


\author{
Budapesti Corvinus Egyetem \\ Politikatudományi Doktori Iskola
}

\title{
A társadalmi tőke fejlődése a magyar-román határ menti övezetben
}

Ph.D. értekezés

Csetnek Tünde Tímea

Budapest, 2013 
“Kutatási munkámat nem választom el az életemtől. Számomra ez valóban az élet keresése, megértése és annak a tudásnak a létrehozása, amit élö tudásnak neveznek. Ez a tudás az, ami egyaránt érvényes a velem együttmüködö emberek és a magam számára is."

(Marja-Liisa Schwantz) 


\section{Tartalomjegyzék}

Bevezetés................................................................ 9

\section{Fejezet: A KUTATÁS ELMÉLETI ÉS MÓDSZERTANI KÉRDÉSEI}

1.1 A kutatás célja...................................................... 12

1.2 A kutatás felépítése............................................. 12

1.3 Kutatási kérdések és módszertan....................................... 14

\section{Fejezet: TÁRSADALMI TŐKE ÉS CIVIL TÁRSADALOM}

2.1 Meghatározások és fogalmak......................................... 24

2.2 Intézményesülés és klaszter elméletek................................. 32

2.3 A határmentiség intézményi formái és lehetőségei....................... 44

2.4 A határmentiség fogalma............................................ 55

\section{Fejezet: TÁRSADALMI KAPCSOLATHÁLÓK A HATÁR MENTÉN ÉS AZ EGYÜTTMÜKÖDÉS FORRÁSAI}

3.1 Határ menti együttmüködések és hálózatok............................ 67

3.2 Határ menti együttmüködési programok elemzése...................... 75

3.3 Európai Területi Együttmüködési Program.............................. 88

3.4 A partnerség vizsgálata a határ menti térségben.......................... 96 


\section{Fejezet: HATÁR MENTI PÁLYÁZATOK, INTÉZMÉNYEK ÉS TÁRSADALMI TŐKE}

4.1 Az intézményi kapacitás és a fejlesztés kapcsolata........................ 103

4.2 Együttmüködés és eredményesség a határ menti térségekben................ 126

4.3 A programterület és vizsgált övezet bemutatása.......................... 141

4.4 Határ menti index és kutatási eredmények............................... 146

\section{Fejezet: VÉGKÖVETKEZTETÉSEK}

5.1 SWOT elemzés...................................................... 165

5.2 Fejlesztési irányok és lehetőségek..................................... 176

5.3 Az akciókutatás eredményei - innováció a határ menti térségek fejlesztésében 178

5.4 Általános javaslatok a határ menti együttműködési intézményrendszerről..... 185

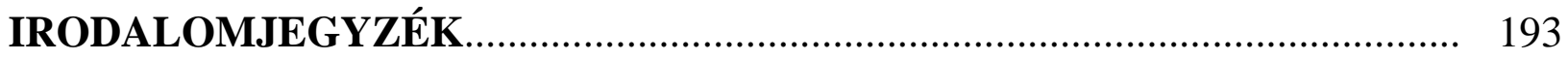

PUBLIKÁCIÓK JEGYZÉKE......................................................................... 209

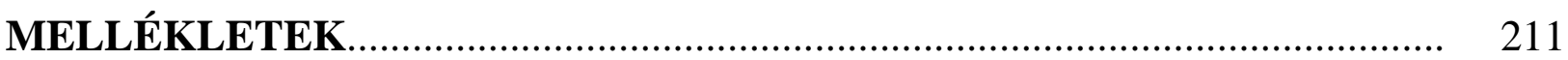




\section{Ábrajegyzék}

1. ábra: Civil szervezetek száma az Érmelléken..................................... 38

2. ábra: Civil szervezetek száma tevékenységi körük szerint az Érmelléken ......... 40

3. ábra: Civil szervezetek száma a magyarországi részen .......................... 41

4. ábra: Civil szervezetek száma tevékenységi körük szerint a magyar vizsgálati részen

5. ábra: Az együttmüködés típusai

6. ábra: Fizikai hálózatok a magyar-román határ mentén

7. ábra: Intézményi hálózatok a magyar-román határ mentén

8. ábra: Magyar pályázatok száma és értéke az INTERREG IIIA 2004-2006

Román-Magyar Együttmüködési Program keretében

9. ábra: Román pályázatok száma és értéke a PHARE 2004-2006 RománMagyar Együttmüködési Program keretében

10. ábra: A kapacitás fogalma az ESA Delft meghatározása alapján

11. ábra: saját szerkesztés a GDRC programjainak elemzése alapján

12. ábra: saját szerkesztés az ENSZ és a WSF kapacitásfejlesztési szintjei alapján.

13. ábra: A határ menti (cross border) indikátor módszertana .......................

14. ábra: Az információ áramlása az időjárás elörejelzési rendszerben

15. ábra: A javasolt létrehozandó inkubátorház szerepe 


\section{Táblázat jegyzék}

1.táblázat: PHARE CBC pályázatok száma ......................................... 77

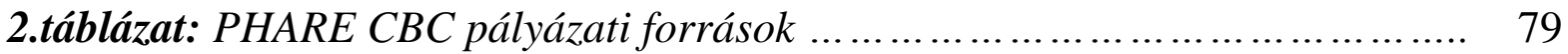

3.táblázat: INTERREG IIIA magyar pályázatok száma ............................. 85

4.táblázat: A Pharee CBC román pályázatok száma ............................... 86

5. táblázat: Az ETE román-magyar közös pályázatok száma ....................... 94

6. táblázat: A román szervezetek indikátor száma ................................... 153

7. táblázat: A magyar szervezetek indikátor száma .......................... 154

1.számú térkép: A szükebb kutatási terület lehatárolása ........................... 36

2. számú térkép: A magyar-román határ menti .................................... 142 


\section{KÖSZÖNETNYILVÁNÍTÁS}

Témaválasztásommal olyan területet vizsgálhattam, amely érdekel és állandó jelleggel foglalkoztat, hiszen életem részévé vált ez a tevékenység. Nagymértékben befolyásolta életem, hogy 2006-ban a Doktori Iskola vezetői, oktatói bizalmat szavaztak és felvételt nyertem a programba. A kutatási témám ötletét nem kizárólag a Régiófejlesztés az Európai Unióban címü tantárgy oktatása és az ehhez kapcsolódó témák feldolgozása adta, hanem a környezetemben, a román-magyar és magyar-szlovák-román-ukrán határ mentén megvalósított közös pályázatok készítése és az ezekben szakértőként kifejtett többéves tevékenységem során is a kutatási témámra fókuszáltam.

Köszönetet mondok mindazoknak, akik 2006-tól folyamatosan segítették kutatómunkámat:

Dr. Jenei György professzornak, kutatásvezetőmnek, akinek kutatómunkája példaértékủ számomra, és eddigi életútja, munkássága, tevékenysége és odaadása követendő etalonként lesz jelen életemben.

A Budapesti Corvinus Egyetem, Alkalmazott Politikatudományi Doktori Iskola vezetőinek, oktatóinak, professzorainak, munkatársainak, akik megértéssel követték törekvéseimet, és minden lehetséges eszközzel támogatták kutatásaimat. Külön köszönetet szeretnék mondani Ilonszki Gabriellának, mivel lehetőséget biztosított számomra a TÁMOP-4.2.1/B-09/01/KMR-2010-0005, Hatékony állam, szakértő közigazgatás, regionális fejlesztések a versenyképes társadalomért címü alprojektben való részvételre, mely révén lehetőségem nyílt a kérdöívem tesztelésére a magyar-szlovák határ mentén is. Ilonszki Gabriella a doktori tanulmányaim folyamán támogatott és számos hasznos információval látott el. Külön köszönettel tartozom még Ágh Attilának is, hiszen szakmai segítsége, publikációi és javaslatai jelentős mértékben befolyásolták a dolgozat elméleti megalapozását és a kutatás gyakorlatának részleteit. 
Köszönetet szeretnék mondani munkahelyem, a nyíradonyi székhelyü Európakapu Korlátolt Felelősségü Európai Területi Együttmüködési Csoportosulás és a Szatmárnémetiben működő Babeş-Bolyai Tudományegyetem, Politikatudományi, Helyi Közigazgatási és Kommunikációs Tanszék vezetőinek és a munkatársaimnak, akik mindenben támogattak, hogy a szükséges határidők, keretek és utazások a kutatás sikeres kivitelezésében megvalósulhassanak.

Külön kiemelném és megköszönném dr. Balogh Márton egyetemi munkatársamnak és a Civitas Alapítvány igazgatójának segítségét, aki minden téren támogatott munkám során. Megköszönném Suta István, a Szatmári BabeşBolyai Tudományegyetem, Politikatudományi, Helyi Közigazgatási és Kommunikációs Tanszék igazgatójának segítségét, megértését és támogatását.

Végezetül hálásan köszönöm családtagjaimnak, hogy személyes bátorításukkal hozzájárultak doktori kutatásaim sikeres lefolytatásához és a disszertációm létrejöttéhez. Édesapámnak, aki támogatott tanulmányaim során, ösztönözte és szorgalmazta a disszertációm elkészítését, és Édesanyámnak, aki megteremtette a megfelelő hátteret a munkához.

Külön köszönettel tartozom páromnak, aki türelmével és pozitív életszemléletével végig mellettem állt. 


\section{BEVEZETÉS}

$\mathrm{PhD}$ dolgozatom a részvételi akciókutatás müfajába tartozik ${ }^{1}$. Ezek a Magyarországon és nemzetközileg is elterjedt kutatások általában hagyományos társadalomtudományi kutatásként indulnak és "menet közben" váltanak át részvételi akciókutatásba.

Mi különbözteti meg a részvételi akciókutatást a hagyományos társadalomtudományi kutatástól? A részvételi akciókutatás célja praktikus tudás létrehozása, amely nem csak elméleti információt szolgáltat, hanem a gyakorlatba is átültethetőek. Ezáltal társadalmi és közösségi célokat szolgálnak, valamint a kutatás során személyes kapcsolatok és elköteleződések épülnek ki, továbbá a kutató feladja külső "semleges" nézőpontját és elköteleződik a partner csoportok iránt, és kialakul a tudás és az akciók összekapcsolódása.

$\mathrm{PhD}$ dolgozatom a részvételi akciókutatás sajátos esetének tekinthető. Nem hagyományos társadalomtudományi kutatásként indult, hanem éppen ellenkezőleg: részvétellel és akciókkal. A közösségi részvétel és az ismétlődő akciók generáltak kutatói érdeklődést.

Munkám során olyan empirikus tapasztalatokra tettem szert, amelyek mennyiségi és minőségi elrendezést igényelnek. Miért is fontos ez az elrendezés? Ennek két oka van. Egyrészt azért, hogy kiismerjem magam a tapasztalatok “útvesztőjében”, másrészt azért, hogy olyan struktúrát és tartalmat alakítsak ki, amely lehetőséget teremt arra, hogy a tapasztalatokat közérthető módon fejezzem ki.

Célom praktikus tudás létrehozása, ami azt jelenti, hogy kapcsolat és elköteleződés füz a kutatás tárgyát képező közösségekhez. Ugyanakkor sajátos

\footnotetext{
${ }^{1}$ Participatory Research Action - angol rövidítése: PAR
} 
vonás, hogy az én esetemben nem kellett feladnom a kutató "külső" nézőpontját, hiszen kezdetektöl fogva a kutatott közösségek részének tekintem magam.

A kutatók a kutatási munka elején úgynevezett krédóval rendelkeznek, amely alapját képezi az elvégzendő kutatási munkának. Számomra már 2006-ban amikor elkezdtem $\mathrm{PhD}$ dolgozatom tervezetének megírását - biztos volt, hogy az egyetlen "járható út" a határ menti együttmüködés vizsgálatában az akciókutatás. $\mathrm{PhD}$ dolgozatom célja a határ menti együttmüködési lehetőségek és korlátok feltárása egy átfogó kutatási dolgozat formájában, az intézményi kapacitás "szemüvegén" keresztül, felhasználva az elvégzett akciókutatás eredményeit. Meggyőződésem, hogy a határ menti közös, valós fejlesztés csak a térségben tevékenykedő aktív szervezetek bevonásával valósulhat meg, hiszen a fejlesztési folyamatok kezdeményezői a helyi intézmények és lakosok. Viszont azt is figyelembe kell venni, hogy az egyes pályázatok megvalósítása nagymértékben függ a helyi szervezetek hozzáállásától is: képesek és hajlandóak-e felelősséget vállalni a közösségért, ténylegesen felvállalják-e intézményi céljaikat?

A román-magyar határ mentén végzett empirikus kutatásom - 2006-tól napjainkig - túllép a hagyományos kutatási kereteken, hiszen tudatosan beleavatkoztam a vizsgált térség ${ }^{2}$ életébe. Szerepem a térségben nem független volt, hanem mint pályázatíró, vidékfejlesztéssel foglalkozó szakember és oktató különböző határon átnyúló képzéseken vettem részt, előadóként. Emellett civil klaszter kezdeményezőként is jelen voltam már az első pályázati kiírások idejében. Ennek köszönhetően elmondható, hogy nem tartottam a megszokott távolságot a "kutatott közegtöl”, azaz a célcsoporttól, hanem részese, sőt talán néha még irányítója is lettem egyes kezdeményezéseknek, melyeket a célcsoport által képviselt szervezetek valósítottak meg. Figyelembe véve mindezeket elmondható,

\footnotetext{
${ }^{2}$ A vizsgált térség a Románia-Magyarország Határon Átnyúló Együttmüködési Program 2007-2013 és a PHARE CBC/INTERREG III. A programok célterülete: Szatmár, Bihar, Arad és Temes megyék Romániából, valamint Szabolcs-Szatmár-Bereg, Hajdú-Bihar, Csongrád és Békés megyék Magyarországról.
} 
hogy kutatásom tulajdonképpen olyan tudományos kutatás, amely a megértés és a változás, az elmélet és a gyakorlat közötti kapcsolatot fejezi ki, és amely a kutatók és a kutatásba bevont célcsoport közötti együttmüködés és közös fellépés által hoz létre új tudást (Nielsen-Svensson, 2006:89-92).

A „közös kezdeményezés” mint a regionális vagy helyi közpolitika-formálás egyik lehetséges eszköze, nem újszerű szemlélet. A „bottom-up”-ként közismert közelítés megjelenik az angolszász irodalomban is és szó szerint fordítva „alulrólfelfelé” építkezésnek nevezhetjük. A konkrét kutatási témámban a határ mindkét oldalán beszélhetünk alulról építkező kezdeményezésekről, a felvetődő kérdés pedig az, hogy a határon átnyúló együttmüködési pályázatok megfelelő pénzügyi eszközei-e a „közös kezdeményezésnek”, tehát az együttmüködő partnerségeknek.

Ha a közpolitika szemszögéből közelítem meg a „közös kezdeményezés” fogalmát, akkor kijelenthetem, hogy ez olyan cselekmény sorozat, melyet közvetlenül az érintett szereplök kezdeményeznek és dolgoznak ki, illetve keresnek megoldást - elébe menve a külső közpolitikai szereplők (pl. állami szervek) által kínált megoldási és beavatkozási lehetőségeknek. PhD dolgozatom egyik vizsgálati része az, hogy melyek azok a területek és problémák, ahol a kezdeményezők (köztük akciókutatóként én is) megoldást tudnak találni saját problémáikra saját eszközökkel, akár az állami szervek beavatkozása nélkül is. 


\section{FEJEZET: A KUTATÁS ELMÉLETI ÉS MÓDSZERTANI KÉRDÉSEI}

\subsection{A kutatás célja}

Kevés olyan részvételi folyamat létezik, ahol a probléma felismerésétől, elemzésétől, a célkitűzések meghatározásától kezdve a megvalósításon át az értékelésig az információk túlnyomó része a vizsgált területekről származik (Dewulf et al. 2005: 19-22).

Empirikus kutatásom célja az, hogy a határ menti övezetben végzett kutatási eredményekre alapozva a részvételi akciókutatás révén, a térségben müködő szervezetekkel együttmüködve és őket segítve kidolgozzam és elindítsam a valós, határon átnyúló területi fejlesztést elősegítő intézményi keretet, mely Európai Területi Együttmüködési Csoportosulásnak nevezhető. Kutatási eredményeimmel egy modell értékü intézmény létrehozását szeretném segíteni.

Az akciókutatás fókuszában a határ menti együttműködő intézmények problémái, valamint a megoldási ötleteim álltak a térségfejlesztési alternatívákat illetően. Az akciókutatást a fenti cél elérése érdekében három különböző szakaszra osztottam fel:

1. Az akciókutatás megalapozása: Nevezhető előkészítési szakasznak is, hiszen ebben a fázisban történik a nemzeti és nemzetközi elméleti irodalom eredmények tanulmányozása és szintetizálása, valamint a különböző releváns jogi hátterek ${ }^{3}$ feltárása, és bemutatása. Ugyancsak az előkészítési szakasz része a folyamatban résztvevő intézmények,

\footnotetext{
${ }^{3}$ Fontosnak tartom megvizsgálni mindkét érintett állam, azaz Románia és Magyarország, de főként az Európai Unió szabályozási kereteit is.
} 
szervezeti struktúrák szereplői körének definiálása és a határ mentén élők elvárásainak azonosítása.

2. Helyzetelemzés: A problémafeltáró vizsgálat eredményei alapján készül el a helyzetelemzés. A helyzetelemzés különböző módszerekkel kerül kidolgozásra: mélyinterjúk, félig strukturált interjúk, fórumok, kerekasztal megbeszélések, kérdőíves felmérések, terepbejárás, statisztikai adatok elemzése stb. A helyzetelemzés végén elkészül egy SWOT elemzés, mely összegzi a határ menti térségben fellelhető erősségeket, gyengeségeket, lehetőségeket és veszélyeket.

3. Fejlesztési javaslatok megfogalmazása: Az elkészített helyzetelemzést a résztvevők tanulmányozzák és közösen megfogalmazzák a fejlesztési igényeket, lehetőségeket. Minden megfogalmazott lehetséges célhoz eszközöket párosítok, ezáltal megjelenik a $\mathrm{PhD}$ praktikus használatának innovatív jellege is.

\subsection{A kutatás felépítése}

A téma beható megismeréséhez és megértéséhez a kutatást az alapoktól kezdtük, mégpedig a dolgozat első fejezetében (1. Fejezet: A kutatás elméleti és módszertani kérdései) a legfontosabb fogalmak és elméletek bemutatásával, a dolgozat módszertanának felvázolásával és ismertetésével.

A társadalmi tőke és a határ menti civil társadalom vizsgálata a második fejezet témája (2. Fejezet: Társadalmi tőke és civil társadalom). Ezen fejezetben kiindulván az elméleti alapokból - elkészítünk egy vizsgálatot a szükebb kutatási 
térben (a két román és a két magyar megye lehatárolt területén). Ez a kutatás választ keres az első kutatási kérdésre és megalapozza azt.

A dolgozat harmadik része a társadalmi kapcsolathálókat vizsgálja. Itt nem csupán elméleti szinten kerülnek bemutatásra azon intézmények, melyek befolyásolhatják a társadalmi kapcsolatokat, hanem konkrétan megvizsgálásra kerülnek azok a határ menti intézmények, melyek részt vesznek az együttműködésben és befolyásolják a társadalmi tőke alakulását. Ugyanezen fejezetben kerülnek bemutatásra a megvalósított pályázatok a magyar-román határ mentén.

E fejezetben bemutatásra kerülnek a határ menti együttmüködést és társadalmi kapacitást támogató források, pénzügyi eszközök, valamint a pályázati adatok kiértékelésével felvázolásra kerülnek a pályázati eredmények, míg a fejezet végén javaslatokat fogalmazunk meg a határ menti együttmüködés fejlesztése érdekében. (3. Fejezet: Társadalmi kapcsolathálók a határ mentén és az együttmüködés forrásai).

A kutatás negyedik fejezetében (4. Fejezet: Határ menti pályázatok, intézmények és a társadalmi tőke) a társadalmi tőket elősegítő, támogató pályázatokat vizsgáljuk meg, valamint felmérjük-értékeljük a szükebb területi térben való pályázati szándékot. Egy másik cél az, hogy a negyedik fejezetben bemutatásra kerüljenek azon intézmények, melyek képesek integrált pályázatok megvalósítására, melyek nem csak a terület fejlesztését segítik elő, hanem a társadalmi tőkét és a civil szerveződéseket is támogatják. Ezen fejezetben dolgoztam saját módszertant dolgoztam ki, mely a pályázatok eredményességét méri egy átfogó kérdőív segítségével. 
A dolgozat záró részében (5. Fejezet: Végkövetkeztetések) konkrét ajánlásokat fogalmazok meg. Ebben a fejezetben jelennek majd meg összesítve a románmagyar és a magyar-szlovák határ mentén végzett saját kutatási eredmények, továbbá minden egyes vizsgált témakörhöz javaslatokat és ötleteket mellékelek. A dolgozat fő indítványa a támogatási intézményrendszerhez kötődik.

\subsection{Kutatási kérdések és módszertan}

A társadalmi tőke szerepe egyre erőteljesebben megjelenik. (Kapcsolatban lévén olyan folyamatokkal, mint például az indusztrializáció, globalizáció, gazdasági fejlődés, gazdasági válságok stb.). A társadalmi tőke fogalmához az egyik vonatkozási pont Robert D. Putnam munkássága (1993, 2000, 2002).

A társadalmi töke megjelenése ugyanakkor felismerhetö Mark Granovetter (1973:1360-1380), Pierre Bourdieu (1997:157-168) és James S. Coleman (1994:99, 1998: 11-24) munkáiban is. A társadalmi tőke, mint fogalom már felismerhető Hanifan kutatásaiban (1916:130-138, 1920) a vidéki oktatási közösségek elemzései során.

Ezen elsődleges kutatások alapján elmondható, hogy a társadalmi tőke olyan, az emberek mindennap életével kapcsolatos interakciók, kötődések és beállítódások, melyek közösségekben jönnek létre, amelyek egy adott társadalmat alkotnak (Hanifan esetében a vidéken élők közössége és az oktatásban résztvevő személyek).

Hanifan kutatásaiból arra a következtetésre lehet jutni, hogy az emberek közötti szimpátiák, kapcsolatok és értékorientációk társadalmi tőkét alkotnak. Jacobs (1961) kutatásai is a társadalmi tőke felé irányultak, hiszen kutatási területe az életben és a szomszédságban kialakult kapcsolatok vizsgálatára fókuszált. 
Ezen elsődleges felismerések után a nyolcvanas években több szélesebb körü fogalom született a társadalmi tőké meghatározására. 1980-ban számos gazdaságelmélet született meg.

Megemlíthető a Ben-Porath (1980) által kidolgozott úgynevezett F-kapcsolatokra épített elmélet. Ennek megfelelően a gazdasági csere hálózataiban F-kapcsolatok alakulnak ki Ben-Porath szerint, melyek a következőek: családok (Families), barátok (Friends) és vállalatok (Firms). Viszont Bordieau (1998) egy teljesen más szemszögből közelíti meg a társadalmi tőkét, mégpedig úgy, hogy a gazdasági, kulturális és társadalmi tőkét összevonja (rekonverzióként elemzi a fogalmakat), és társadalomelméleti szempontból mutatja be a társadalmi tőkét. Fő elemzési pontjai a társadalmi, a szimbolikus és a kulturális tőke.

Coleman (1998) szerint a társadalmi tőke a személyek közötti kapcsolatokban ismerhető fel és akkor jön létre, amikor ,az emberek közötti kapcsolatok úgy módosulnak, hogy elősegítsék a cselekvést" (Coleman 1998:17).

A társadalmi tőkének ennek megfelelően három típusa létezik: az elvárások, az információs hálók/csatornák és a szankciók/normák. Coleman-nak köszönhetően (1994) a társadalmi tőke a társadalomelmélet egyik jellegzetes meghatározójává vált.

Coleman-nál megjelenik egy új megközelítés, mégpedig a közjó megközelítés. Eszerint a társadalmi tőke egyes típusainak előnyeit nem csak azok a fogyasztók élvezhetik, akik létrehozták, hanem mások is, mivel teljesen képtelenség és legalábbis nehéz feladat volna kizárni másokat a hálózati/kapcsolati rendszerből.

A közjó, mint meghatározó eleme a társadalmi töke meghatározó eleme Putnam (1993:163-167, 2000) kutatásaiban teljesedik ki. Szerinte a társadalmi tőke kollektív ismérv: amely erős társadalmi kapcsolati hálókat, szolidaritást, bizalmat, normákat, erős civil szervezeteket, személyek közötti kapcsolatokat, problémamegoldó készségeket jelent. 
Putnam szerint (Putnam 2000:19) a társadalmi tőke erősen kötődik a „civil bátorság/kurázsi” jelenséghez, hiszen véleménye szerint a civil kurázsi sokkal erőteljesebb, ha ezek a kapcsolatok egy változó és kiterjedt, intenzív társadalmi hálózatba ágyazódnak. Ennek megfelelően elmondható, hogy Putnam (1993:165) szerint a társadalmi tőke egy közösségi-kulturális folyamat, melynek két irányba van hatása: elsősorban magába foglalja a közös cselekvésre való kapacitást és a közintézmények felé irányuló bizalmat, másodsorban pedig a társadalmi tőke sajátos jellemzője nagyobb közösségeknek, mint például egyes nemzetek, régiók vagy saját kutatásunkban a határon átnyúló térségnek is.

Fukuyama (1995:10) teljesen más szemszögből közelíti meg a társadalmi tőkét. Fukuyama szerint a társadalmi tőke egyik fö eleme a társadalmi együttmüködés. Fukuyama szerint a társadalmi tőke nemcsak a bizalom és az emberek közötti együttmüködést elősegítő normák összegzése, hanem a valláserkölcsöt is jelentik. Szerinte a társadalmi tőkének két fő eleme van: a kooperáció (együttmüködés) és a mobilitást kiváltó készség.

Putnam a társadalmi tőke és a civil társadalom kapcsolatában rámutatott bizonyos hanyatlási folyamatra mutatott rá (Putnam, 1993, 2000, 2002:189-190). Putnam szerint a második világháborút követően Amerikában az erőteljes, aktív civil társadalmi élet hanyatlásnak indult. Szerinte jelentősen csökkent a részvétel a népszerü amerikai teke játékban, melyre a híres „Bowling Alone” könyv címe is utal. Az Egyesült Államokban a tekézők száma 1993-ig 10 százalékkal nőtt, viszont a teke egyesületekben játszók száma 40 százalékkal csökkent. Putnam szerint ,a teke-csapatok esete a társadalmi tőke hanyatlását illusztrálja” (Putnam, 2000:228-229).

A szerző szerint az amerikai demokrácia és gazdaság sikerének alapját nagymértékben befolyásolja a civil elkötelezettség. Ez a civil elkötelezettség megjelenik Tocqueville (1993:973-974) „Az amerikai demokrácia” címü könyvében is. A kérdés az, hogy a hanyatló magyar-román társadalmi és 
gazdasági élet sikeressé és versenyképessé tétele lehetséges-e ilyen „amerikai” jellegü meglátások alapján. Tehát ha a határ mentén a társadalmi tőke növekedne és a civil összetartás megerősödne, akkor várhatóan a társadalmi kapacitások és a versenyképesség is javulna.

Ez a kijelentés a civil társadalom és a „közösségi” problémák vizsgálatával válaszolható meg. Összetett kérdésről van szó, hiszen a putnami megközelítés szerint is a társadalmi tőkének két jellegzetes része van:

- Társadalmi hálózatok: látogatások, szomszédi kapcsolatok, társadalmi események

- Civil elkötelezettség: a közösségi életben való részvételi szándék, tagsági viszonyok, stb.

A Putnam-féle megközelítést kicsit tovább fejlesztve, a határ menti társadalmi tőkét a következő két megközelítésben szeretnénk megvizsgálni:

- Határ menti hálózatok: azon intézmények, kapcsolatok, források, melyek elösegítik a társadalmi kapcsolatokat, az emberek közötti people-to-people jellegü találkozókat, eseményeket, együttmüködéseket, stb.

- Civil lehetőségek és hálózatok: a klaszterre és hálózatra való szándék, hajlam a határ menti intézmények részéről, valamint az ezekben rejlő lehetőségek felismerése, közös intézményekben való részvétel, stb.

A két fenti megközelítés vizsgálata első kutatási kérdésünkre adja meg a választ, mégpedig:

H1: a magyar-román határ mentén számos gazdasági és fejlödési lehetőség van, viszont a társadalmi töke mértéke alacsony, így a határ mentén lévö területek nem fejlödnek, melynek feltételezésünk szerint fö oka az, hogy 
alacsony a társadalmi töke. Feltételezhetö, hogy a társadalmi töke növelésével, a civil társadalom megerösödésével új fejlesztési irányokat kaphatna a térség.

A fenti kutatási kérdés vizsgálatára a következő kutatási módszertant alkalmazzuk: a két-két határ menti megyéből (Hajdú-Bihar és Szabolcs-SzatmárBereg megye Magyarországról, valamint Szatmár és Bihar megye Romániából) kiválasztunk egy lehatárolt teret, és statisztikai adatokat használva elkészítünk egy katasztert a müködő gazdasági és civil szervezetekröl. A kataszter elkészítésére nem csupán statisztikai adatokat használunk ${ }^{4}$, hanem felvesszük a kapcsolatot a helyi szereplőkkel is, valamint a községek és a városok polgármestereivel egyaránt.

A meglévő adatok alapján előkészítek egy akciótervet, egy cselekvési folyamatot, melybe bevonjuk a helyi szereplőket. Viszont a cselekvési terv bemutatása előtt megvizsgálom a klaszter és hálózati együttmüködési lehetőség hátterét.. Itt érdemes megvizsgálni a két ország - Magyarország és Románia - törvényi kereteit, hiszen meg kell találni az együttmüködést elősegítő közös intézményi formát, mely mindkét tagállamban lehetőséget ad a társadalmi tőke és a kapacitások közös, határon átnyúló fejlesztésére.

Ha elkészült a cselekvési terv, az aktív civil szervezeteknek és helyi szereplöknek több találkozót tartunk, amelynek során bevonjuk őket a kezdeményezésbe és a közös fejlesztésbe. A cél az, hogy minden aktív civil szervezetet bevonjunk és olyan müködő intézményt alakítsunk ki, mely nem csak elméleti módszer, hanem konkrétan használható eszköz is, amely elősegíti a határ menti társadalmi tőke javítását és egyben elősegíti a társadalmi, gazdasági kapcsolatok fejlesztését is.

A fórumok célja nem csak egy javasolt modell bemutatása lesz, hanem elözetesen több találkozón próbáljuk együtt felismerni a térség problémáit, melyekre

\footnotetext{
${ }^{4}$ Helyi szinten aktuális adatbázisok, információk léteznek az aktív, működő cégekről, vállalkozásokról és civil szervezetekröl.
} 
közösen keresünk megoldásokat, valamint felmérjük a közös együttmüködési lehetőségeket.

A kutatás második kérdése kapcsolatos a társadalmi tőkével, viszont főként nem a határ menti társadalmi kapcsolatokat vizsgálja, hanem az ezen kapcsolatokat elősegítő intézményi hálókat. A gazdaság szerkezetének vizsgálata főként a hálózatok mentén lehetséges.

Castells szerint (2005:373-405) a hálózati együttmüködés sikere az, hogy az új társadalmi és gazdasági környezetben az adott hálózatok képesek hatékonyan tudást alkotni és információt feldolgozni. Az ilyen jellegü hálózatok másik sajátossága, hogy gyorsan alkalmazkodnak a globális körülményekhez.

A kutatási kérdés megfogalmazásához a társadalmi tőke, és ezen tőke putnami társadalmi kapcsolatháló értelmezését vesszük alapul. A meghatározás szerint (Putnam 2000: 324-325, Flap 2002) a társadalmi tőke eszköze négy fontos társadalmi kapcsolatháló, melyek mozzanatai a következőek:

- Segítési normák az emberek és közösségek között

- Információ átadása - fogadása, és a teljes információáramlás folyamata

- A közösségek versenyképessége és fejlődése

- Társadalmi együttmüködés vagy közösségi tudat, bizalom és szolidaritás

A második kutatási kérdés (H2) kiindulópontja a fenti négy társadalmi kapcsolatháló. Véleményünk szerint a gazdasági fejlődést nem csupán a társadalmi tőke befolyásolja, hanem az intézményi, közintézményi hálózatok, együttmüködési, keretek is.

A határ menti pályázatok nyertesei között többéves együttmüködési, információátadási - fogadási folyamat, közös fejlesztés, fejlődés, társadalmi együttmüködés 
alakulj ki, hiszen csak így volt lehetséges a közös CBC pályázat megvalósítása ha ezen közös feltételek részei voltak a pályázati kérelemnek.

A partnerség fogalma alatt nem csak olyan együttmüködéseket kell érteni, amelyeket európai uniós források kezdeményeztek-támogattak, hanem olyanokat is, melyek alulról, helyi szintről indultak. Ezek valamilyen társadalmi tőke jellegü kezdeményezések, melyek nem kényszer hatására, sem pedig hatóságok felsőbb utasítására indultak, ugyanakkor nem voltak korlátozva és keretekbe zárva sem. Az első hipotézis továbbgondolása nyomán feltételezhetö, hogy az együttmüködésekben részt vevő szervezeti kapcsolatok tematikusan és tipizáltan alakultak ki, tehát a partnerségek müködési feltételei adottak voltak. Vagyis az intézmények úgy próbálták kialakítani partnerségi kapcsolataikat, hogy azonos jellegü és tevékenységi körrel rendelkező szervezetet kerestek.

Érdekes az a tény is, hogy a kialakított partnerségek mennyire időtállóak. Ezen a ponton a kutatási kérdés az, hogy a közintézmények, civilek befolyásolják vagy sem a társadalmi kapcsolatháló kialakitását, és hogy a pályázatokban „mesterségesen” vagy természetesen alakultak-e ki a kapcsolatok, valamint hogy ezen kapcsolatok „konjunktúrafüggöek”-e és csupán a pályázati források elnyerésére jöttek-e létre, vagy hosszú távú partnerségek alakultak ki? (H2)

A második kutatási kérdés megválaszolására a következő módszereket választottam: a PHARE CBC 2004-2006 időszakban megvalósított pályázatok vezetőit megkeressük egy kérdőívvel, és a helyszínen a megfigyelés módszerével közösen alkalmazzuk. A rendelkezésünkre bocsátott pályázati adatlapokat is megvizsgáljuk, összpontosítva a pályázati eredményekre, indikátorokra és az eredmények fenntarthatóságára.

A kutatási kérdés két vonalon vizsgálható: a már lezárt pályázatokért felelős intézmények helye és szerepe a társadalmi kapcsolathálóban, valamint a jelenlegi jogi formák, intézmények, melyek elősegíthetik az együttmüködést. 
Tehát célunk megnézni, hogy milyen intézmények vettek részt az együttmüködésben és milyen eredményeket tudtak felmutatni, konkrétan a társadalmi kapcsolati hálókra és indikátorokra összpontosítva. Emellett egy másik célunk megnézni, hogy milyen más intézményi forma segítené elö az együttmúködést. Az elkészült eredmények két fórumon kerülnek bemutatásra a szük vizsgálati terünkben (a két magyar és a két román megyében).

A fórumokra a kiválasztott - és már az első hipotézisben is vizsgált - települések polgármestereit, intézmény vezetöit hívjuk meg, és közösen próbáljuk megtalálni a választ arra, hogy milyen együttmüködési forma a megfelelő a 2014-2020-as programozási időszakra. Ez az együttmüködési forma nem csupán pályázati forrást hoz a térségbe, hanem hosszú távon megteremti a társadalmi hálózatot, mely a térségfejlesztés alapjává képes válni a közeli jövőben.

A társadalmi tőke megerősítéséhez viszont szükség van erőforrásokra a vizsgált térségben. Itt most konkrétan a pénzügyi forrásokra gondolunk, hiszen a határ menti megyék Magyarországon és Romániában is elszegényedett, elnéptelenedett, magas migrációval és komoly társadalmi problémákkal terhes térségek.

Harmadik kutatási kérdésünk (H3), hogy a megfelelő tőke (itt főként európai uniós forrásokra gondolunk) megléte a térségben elősegítheti-e vagy sem a határ menti fejlődést, valamint a társadalmi tőke megerösödését. Ennek vizsgálatára meg kell nézni, hogy előzőleg milyen - főként határon átnyúló fejlesztéseket támogató - források érkeztek a térségbe. Egy másik eleme a vizsgált kérdésnek, hogy van-e megfelelő szándék és pályázati "kedv", tehát megtalálhatóak-e a térségben az olyan intézmények, amelyek képesek felvállalni a javasolt fejlesztéseket. Feltétezzük (H3), hogy a 2004-2006 időszakban a megvalósult, sikeresnek mondott pályázatok fokozzák az érdeklödést, és hogy a 2007-2013 idöszakban megvalósult pályázatok száma nött, ső́t egy időben a pályázatok számának emelkedésével növekedett a versengés, és ezáltal a pályázatok 
minösége is. Ezen kijelentés arra mutat rá, hogy a térségben számos olyan intézmény van, mely képes lesz a 2014-2020-as programozási idöszakban megvalósítani olyan integrált, határon átnyúló pályázatokat, melyek a térség fejlödését segítik elö.

A fenti kutatási kérdés megválaszolására több szakaszban kerül sor: elsősorban a 2004-2006-os időszakban beadott, megvalósított pályázatok száma kerül kiértékelésre, és ezzel egy időben a 2007-2013-os időszakban beadott, megvalósított pályázatoké is. Ezáltal általános statisztikai számot, arányt kaphatunk arról, hogyan változott a pályázati szándék a határ menti térségben.

A kutatási kérdés második részének a megválaszolására, mely szerint a szük kutatási térben (a két magyar és a két román megyében) van-e olyan megfelelő intézmény, mely integrált pályázatokat képes lesz megvalósítani az elkövetkező pénzügyi programozási időszakban, a következő módon vizsgáljuk meg: az összes határ menti pályázatokból megnézzük, hogy milyen arányban és milyen intézmények voltak támogatva a 2007-2013-as időszakban a szükebb kutatási térben.

A meglévő intézményekkel felvesszük a kapcsolatot és egy közös munkatalálkozót szervezünk, ahol a jövőbeli pályázati ötleteikről, elképzeléseikről beszélünk majd velük. Így átfogó képünk lesz arról, hogy melyek azok az intézmények, amelyek képesek és szándékuk van a térség fejlesztésére.

Egy másik fontos kutatási kérdés - mely közvetlenül kapcsolódik a kutatás végkövetkeztetéséhez is -, hogy a vizsgált kutatási kérdések alapján mi az a legmegfelelöbb intézményi forma, amely a határon átnyúló együttmüködést 
támogatja? Itt nem csupán az a fö cél, hogy javaslatot tegyünk egy olyan intézményi formára, mely leghatékonyabban tudja a határon átnyúló Európai Területi Együttműködési forrásokat felhasználni.

A kérdés az, hogy melyik az a intézményi forma, amely a társadalmi tőkét erősíti, az emberek közötti, valamint az intézmények közötti kapcsolatokat, együttmüködést hosszútávon képes fenntartani. 


\section{FEJEZET: TÁRSADALMI TŐKE ÉS CIVIL TÁRSADALOM}

A fejezetben bemutatásra kerül a társadalmi tőke és a civil társadalom fogalma. A cél az, hogy elméletben bemutassuk ezt a két fogalmat, továbbá a fejezet második részében a részvételi kutatás alapján megvizsgálásra kerülnek a kutatási terület civil szervezeteinek lehetőségei, valamint a konkrét javaslatok és együttmüködési formák. A fejezetben az elméleti elemzéssel és a részvételi kutatással választ keresünk az első hipotézisre.

\subsection{Meghatározások és fogalmak}

Mivel véleményünk szerint a határ menti övezetekben a civil társadalom gyengesége ismerhető fel, így szükséges ezen intézmények támogatása, és ezáltal a társadalmi tökét gyarapító tevékenységek száma is növekedne. Ez a megállapítás a következőket jelenti: olyan intézményfejlesztést kell véghezvinni, amely megfelelően tudja előirányozni a társadalmi tőkét támogató tevékenységek megvalósítását, másfelől pedig olyan közösségépítő tevékenységeket kell kezdeményezni, amelyek megerősítik a határ menti közösségekben a szolidaritást, bizalmat, konszenzust és kompromisszumkészséget.

Ezt a kijelentést alátámasztja Robert Putnam 1993-ban megjelent munkája (Making Democracy Work), melyben az észak- és dél-olaszországi gazdasági különbségekről ír. A szerző szerint a szintkülönbségek fő okozója a horizontális és vertikális integrációs tényezők természete közötti különbség. ÉszakOlaszország modern gazdaságának egyik jellegzetessége a hálózatépítés, mely a horizontális integráció alapja, míg Dél-Olaszországban a vertikális gazdasági integráció nem támogatja a hálózatok kialakulását.(Putnam, 1993:175) 
Az intézményi, társadalmi hatékonyság mércéje a „governance” mint kimeneti legitimáció, míg másik mércéje a társadalmi részvétel mértéke, vagyis a bemeneti legitimáció (input-output legitimáció).

A civil szervezetek vagy a harmadik szektor fogalma különböző módokon jelenik meg. Országról országra más fogalmak jelennek meg, melynek fő okai az eltérő törvényi, létrehozási és müködési feltételek. Magyarországon például alacsony alaptőkével létre lehet hozni közérdekű cél érdekében adományozó alapítványt, míg Romániában csak egyesületet lehet alacsony alaptőkével létrehozni, és alapítvány létrehozásához már magasabb alaptőkére van szükség ${ }^{5}$.

Számos helyen problémaként jelenik meg a különbség, mely a civil szervezet és a nonprofit szervezet között van, ennek egyik oka az európai uniós és az egyes nemzeti jogrendszerek közötti eltérés. Tovább bonyolítja a fogalom megértését a kapcsolódó fogalmak megléte, mint például a nem kormányzati szervezetek (NGOs - nongovernmental organisations), a civil szervezetek (Civil Society Organisations), az önkéntes alapon müködő szervezetek (Voluntary organisations), illetve a karitatív szervezetek (charity organisations).

A történelem folyamán -eredendően- kétféle szereplő különböztethető meg a társadalomban politikailag: az állam és a civil társadalom. Ennek köszönhetően a társadalom két nagy csoportra volt osztva: a közszektorra és a magánszektorra. Ez a klasszikus meghatározás párhuzamosan megtalálható a jogi rendszerben is: a magán- és a közjog. Az idő múlásával ez a felosztás elavultnak bizonyult.

A modern társadalmakban egyre inkább megjelent egy új felosztás: az állam mellett van egy szektor, mely a profit megszerzésére irányítja minden tevékenységét, és egy másik szektor, melynek nem a profitszerzés a célja (ez a nonprofit szektor vagy másképp nevezve a harmadik szektor).

5 A 26-os Kormányrendelet alapján - mely a romániai civil szervezeteket szabályozza -, alapítvány létrehozásához száz minimálbérnek megfelelő összeget kell elkülöníteni egy számlára, mely a megalakulás után a létrehozott alapítvány alaptőkéjét képezi. 
A harmadik szektor hézag pótló-kiegészítő funkciót tölt be. Olyan szolgáltatásokat nyújt, amelytől mind az állami, mind a profitorientált szektor vonakodik, amelynek oka, hogy az ilyen jellegü szolgáltatások ellátásából származó jövedelmek nem jelentenek nyereséget a magánszektornak és financiális-szervezési nehézséget okoznak az állam intézmények számára

A korai kapitalizmus idejében ezen szolgáltatások a szociális szférába tartoztak, és ennek köszönhetően a civil szervezeteket karitatív szervezeteknek is nevezik.

A második világháború után a nemzeti kormányok - legföképpen a nyugateurópaiak - felismerték a civil szektor fontosságát a demokratikus stabilitás biztosításában. Ebben az időszakban lett kézzelfogható, hogy milyen nagy szerepe van a harmadik szektornak a demokrácia biztosításában és megerősítésében. Ennek következtében egységes törvényi keretek készültek, melynek célja az volt, hogy az állam hatása csökkenjen a civil szférában, valamint hogy a civil szervezetek tevékenységei átláthatóbbak legyenek.

Egységes és átfogó elmélet meghatározása a nonprofit szektorra vagy a harmadik szektorra vonatkozóan komplex feladat. Úgy vélekedünk, hogy a legkomplexebb meghatározás 1996-ben született, melyet Lester Salmon és Helmut Anheier (1996:3-4) fogalmazott meg a „Social Origins of Civil Society: Explaining the Nonprofit Sector Cross-Nationally" címü tanulmányban. A szerzők hét kritériumot szabtak meg, melyek teljes mértékben jellemzőek a nonprofit szférára:

1. Intézményesülés - Az első jellemző arra utal, hogy a nonprofit szervezetnek saját célja és struktúrája kell legyen, mely elösegíti a belső fejlődést és a kommunikációt más intézményekkel. Saját jogi személyiséggel rendelkeznek és jogilag be vannak jegyezve.

2. Az államtól való elválasztása (magántermészetü) - A második jellemző arra vonatkozik. hogy a nonprofit szervezetek elválasztódnak az állami 
szervektől, intézményektől, megalakulásuk alapja a szabad kezdeményezési jog és a szabad társulási jog.

3. A profit meg nem osztása - Ez a jellemző arra utal, hogy a nonprofit szervezeteknek nem a profit megszerzése a fő célja. Ez nem azt jelenti, hogy nem szerezhetnek profitot, hanem a megszerzett profit nem osztható el a szervezet „részvényesei”, az alapító tagok vagy a kurátorok között, és csak a célok elérésére használható.

4. Autonómia - Arra vonatkozik, hogy a szervezet céljait a tagok szabják meg és ezen célok elkészítésébe nem avatkozhat be külső szervezet, intézmény. A szervezetnek tehát van valós kapacitása arra, hogy felelősséget vállaljon a döntéseiért, melyek belső müködését és más szervezetekkel való kapcsolatait érintik.

5. Önkéntesség - Arra utal, hogy a nonprofit szervezetek önkéntesen jönnek létre anélkül, hogy egy felsőbb intézmény ezt meghatározza. Továbbá arra is vonatkozik, hogy a nonprofit szervezetekben gyakran találkozhatunk önkéntesekkel.

6. Nem vallási misszionarizmus - A nonprofit szférának nem célja a vallás népszerüsítése viszont lehet céljuk a vallás oktatása.

7. Politikamentesség - Nem vesz részt a politikai viszályokban (nem avatkozik bele a politikai hatalom megszerzésébe és gyakorlásába sem).

Végkövetkeztetésként elmondható, hogy a civil szervezetek magántermészetü intézményesült szervezetek, melyek tevékenykedhetnek, mint informális csoportok, vagy mint bejegyzett magánjogi személyek, és e szervezetek teljes mértékben függetlenek bármilyen közjogi intézménytől. A civil szervezeteknek nem célja sem a politikai hatalom, sem a profit megszerzése. 
Ha megfigyeljük a fejlett országokban müködő civil szervezeteket és a tevékenységi körüket, akkor észrevehető, hogy Nagy-Britanniában és Japánban túlnyomóan az oktatás terén, Németországban és az Egyesült Államokban az egészségügy terén, Franciaországban és Olaszországban pedig a szociális szolgáltatások terén müködnek ilyen típusú szervezetek. Ezekben az országokban az államnak föként felügyelö szerepe van a nonprofit szektorban, vagyis e szervezetek gazdasági-jogi megfelelésének, müködésének felügyeletét látja el, valamint egyes esetekben az állam a tevékenységük ellátásához szükséges eszközök biztosításával segíti a nonprofit szervezeteket. A fejlődésben lévő országokban viszont a nonprofit szervezetek legfőképpen a gazdasági fejlődésben tevékenykednek.

A civil társadalom három fő jellemzővel rendelkezik. A civil társadalomnak kell teljességében beolvadnia a közszférába, teljesen elhatárolva azt a magán- és az állami intézményektől. Egyes elemzők szerint azon politikai pártok, melyeknek irányultságuk és ideológiájuk demokratikus-pluralista, fontos erőt jelentenek a civil társadalom építésében és megtartásában. Ennek ellenére Cohen és Arato (1992:83-117) elgondolásai szerint ezen szervezetek képesek megszerezni a politikai erőt maguknak és azoknak, akiket képviselnek.

A második jellegzetesség a tevékenységek intézményesülésére való hajlamosság, mely elösegíti a civil társadalom kialakulását és megtartását. Másképpen kifejezve tehát nem elégséges egyszerủen helyteleníteni a kormány eljárásait és politikáját még akkor sem, ha ezt nyilvánosan tesszük. Ezt a nemtetszést egy intézmény kell kifejezze, mely jól meghatározott struktúrával rendelkezik, amely lehetővé teszi, hogy a tevékenységeket koordinálja és kapcsolatokat létesítsen más szociális szervezetekkel.

Végül pedig még akkor is, ha a többpárti opció nem egy sine qua non opció azon intézményeknek, amelyek részt vesznek a civil társadalom kialakításában, ezek 
megszűnnek részt venni ebben a folyamatban, amikor túllépik a közjogi párbeszéd törvényi keretét.

Az Oxford politikai szótár így határozza meg a civil társadalmat: „közbenső egyesületek összessége, melyek nem az állam és nem a család (széleskörü), tehát a civil társadalom magában foglalja az önkéntes egyesületeket, cégeket és más korporatív szervezeteket.

A civil társadalom nem az állam teljes lakossága és távol áll attól, hogy egy egyszerü emberi amalgámból tevődjön össze egy adott területen.” „A civil társadalom egy kapcsolatokból és szervezetekből álló sorozat, melynek hajlama van a politikai rendszert átalakítani." (Politikai szótár, 2001:419-420). A szótár ad egy példát is a meghatározásra, rámutatva Franciaország történelmére 1780-tól: „az állam át lett alakítva és át lett fogalmazva többször is, viszont mégis a franciaországi civil társadalom állandó és sajátságos maradt végig. Sem Európa, sem Bretagne vagy Provence, külön véve, még akkor is, ha lehetett volna valamilyen jellegü társadalmuk, egyiküknek sem volt olyan jellegü civil szervezete, mint Franciaországnak."

Dominique Colas arra irányuló erőfeszítése, hogy meghatározza a civil társadalmat, a funkciói felismerését jelenti. Vagyis ,,a civil társadalom funkciója a modern társadalomban az, hogy örizze a biztonságot, megvédje a magántulajdoni jogokat és biztosítsa a szabadságot az egyéneknek. Ha absztrakt módon figyeljük, a civil társadalom a harctér, ahol egymással küzdenek a magánszemélyek más személyek ellen.”(Colas, 1997:237)

A civil társadalom Colas szerint „megengedi nem csak az egyén jelenlétét, mely szubjektíven saját érdekeit nézi, hanem még az egyes állam iránt disszidens csoportok létét is, melyek disszidens léte jogilag megalapozott."(Colas, 1997:343)

A fenti elméletekböl levonhatóak következtetések, melyek komplex képet adnak arról, hogy mit is jelent a civil társadalom és mi a tartalma. A civil társadalom 
tehát az a része a társadalomnak, mely az egyén és az állam között található, és magában foglal többféle egyesületet (tehát nem egy állam lakossága és közel sem egy egyszerü emberi közösség egy adott területen). E szervezetek kapcsolatai között ott vannak az állami intézmények is, melyeknek feladata az egész közösség biztonságára figyelni, megóvni a magántulajdont, az egyén szabadságát biztosítani, valamint befolyásolni más államokat a saját tevékenységeik által. Egyes meghatározások a civil társadalmat ellentétbe helyezik az állami intézményekkel, viszont e vízió ellentétes a jelenleg többség által vallott meggyőződésekkel, melyek fel vélik ismerni a civil társadalom kiegészítő szerepét az állami intézményekkel szemben.

Az ellentétes szemlélet megtalálható a kommunizmus idején született munkákban Közép-Kelet Európában, ahol a civil társadalom úgy van jellemezve, mint olyan eszköz,, amely a kommunista rendszer eltávolítására alkalmas.

Végkövetkeztetésként lehetséges teljes meghatározást adni a civil társadalom fogalmára - figyelembe véve a fogalom összetett jelentését, állandó fejlődését és a változó szociális kontextust -, azonban nehéz lesz olyan teljes meghatározást megalkotni mely hosszú távon megállja a helyét anélkül, hogy változtatásokra lenne szüksége -, úgy, hogy a civil társadalom szerepét és jellemzőit teljes körüen magában foglalja.

A civil társadalomnak tehát kiegészítő szerepe van az állam tevékenységéhez viszonyítva, viszont egy időben ezzel a tevékenységgel a civil társadalom ellensúly is az állam negatív hatásaival szemben, mely több független egyesülésből tevődik össze egy erőközponttal szemben és önkéntesen jön létre olyan személyek összefogásában, akik megegyeznek egy közös magatartásban és megegyeznek abban, hogy a teljes társadalom érdekében járnak el, amelyeket 
előbbre valónak tartanak a saját érdekeiknél. A civil társadalom továbbá a változatosság és a különbségek valós világa, melynek megvan az ereje ahhoz, hogy saját maga alakuljon meg a szabad kezdeményezések révén.

Az Európai Unió a következő dokumentumokban ösztönzi a tagállamokat, hogy a civil társadalom szerepét növeljék:

- 1997-ben a Bizottság „Promoting the Role of Voluntary Organisations and Foundations in Europe" (COM/97/0241) címü dokumentumában hangsúlyozta az önkéntes szervezetek gazdasági és szociális fontosságát. Az önkéntes szervezeteket a demokratikus társadalmak fontos összetevőjének tartotta, és az EU integrációban perspektivikus funkciójú szervezetekként határozta meg öket.

- 1999-ben a Gazdasági és Szociális Tanács (EESC) „The Role and Contribution of Civil Society Organisations in the Building of Europe" (OJ C329, 17,11,1999) címü anyagában bevezette a szervezett civil társadalom (,,organised civil society”) és a civil társadalom szervezetei (,organisations of the civil society") fogalmait az EU közbeszédbe.

- Az EESC dokumentum a civil társadalmat úgy értelmezte, hogy az „olyan szervezeti struktúrák összessége, amelyek tagjainak célja és felelőssége az általános érdek érvényesítése, és amelyek közvetítő szerepet töltenek be a közintézmények és az állampolgárok között” (EESC 1999, 7. 1.).

- A Bizottság 2000-es vitaanyaga (The Commission and Non-Governmental Organisations: Building a Stronger Partnership; COM/2000/11final) már foglalkozott a civil szervezetek multifunkcionális szerepével, megkülönböztetve „az operatív NGO-kat, amelyek szolgáltatásokat nyújtanak (például a szociális gondoskodásban), a képviseleti (advocacy) NGO-któl, amelyek a közvéleményt és a közintézmények politikáját befolyásolják" (European Commission 2000:1.2.). Ez az anyag tartalmazza, 
hogy a civil szervezetek hozzájárulhatnak az európai demokráciák input és output jellegü legitimációjához. A civil szervezetek hozzájárulását említik a részvételi demokráciához („participatory democracy”), az érdekek képviseletéhez - speciális csoportok és ügyek esetében - (,interest representation of specific groups and specific issues"), a közpolitika folyamatához, a projektmenedzsmenthez és az európai integrációhoz.

- A Bizottság 2001-es „White Paper on European Governance” (COM/2001/428final) címü dokumentuma különösen hangsúlyozta a civil szervezetek szerepét az EU-szintủ intézmények és az állampolgárok közötti kommunikációban. A dokumentum hangsúlyozza, hogy a civil szervezetek „strukturált csatornát” biztosítanak a „visszajelzésre, a kritikákra és az ellenvélemények hangoztatására” annak érdekében, hogy a demokráciát erősítsék nemzeti szinten.

\subsection{Intézményesülés és klaszter elméletek}

Porter szerint a fejlődés térszerkezetét is vizsgálni kell. A térszerkezetnek három fő eleme létezik. Szerinte a világon a gazdasági és szociális fejlödés és termelés nagy részét viszonylag kisszámú központok állítják elő. Egy másik megfigyelése

A szerző másik megfigyelése, hogy az egymáshoz hasonló tevékenységi körrel rendelkező szervezetek, intézmények, vállalkozások egymás közelébe települnek, ezzel pedig olyan földrajzi sürüsödési pontokat hoznak létre melyek klaszternek nevezhetőek. Végkövetkeztetésül, Porter szerint a két folyamat végbementével olyan agglomerációk jöhetnek létre melyek sajátos intézményi formát ölthetnek és ezáltal új fejlesztési folyamatokat generálhatnak. Egy másik megfigyelhető eleme a klasztereknek - Porter szerint - hogy egy adott agglomerációban, vagy ha 
saját kutatási témánkat vesszük példának, akkor elmondható egy adott térségröl , hogy a klaszterek olyan innováció tartalommal rendelkeznek melyek új funkciókkal tudnak felruházni egy térséget. (Porter, 1997)

A klaszter fogalmát Porter alapelméletét követve számos meghatározás követte. Netwin szerint a klaszterek: "különböző módón együttmüködő helyi szervezetek, vállalatok, intézmények hálózatai, amelyek földrajzilag koncentráltan tudnak fellépni és megjelenni egy adott térségben, összekapcsolódó tevékenységi és iparágakban." (Netwin, 2007, 61 old.)

$\mathrm{Az}$ Európai Bizottság "Regional clusters in Europe" (2002) címü dokumentumában a következőket írja : a klaszterek vállalatok, intézmények és szervezetek olyan csoportjai amelyek a következő jellemzőkkel rendelkeznek:

- Versenyeznek, viszont szorosan együttmüködnek

- Földrajzilag koncentráltan helyezkednek el egy vagy több régióban

- Adott tevékenységi körrel rendelkeznek és arra szakosodnak folyamatosan

- A klaszterek intézményesülhetnek vagy nem (tehát vagy rendelkeznek irányító szervvel, egy klasszmenedzsmenttel vagy nem)

- Müködési alapjuk az innováció, a szaktudás, az információáramlás és hosszú távú üzleti, fejlesztési növekedést képesek generálni

A klaszter szó eredetileg egy angol kifejezés („cluster” = „csoportba gyüjt”) magyarul történő leírása, jelentése: hálózat, amely a szereplök közötti ésszerü, kölcsönös elönyökön nyugvó együttmüködés gondolatát jelenti.

Regionális szinten az alábbi különböző típusú klasztereket különböztetjük meg az ágazati és a térbeli koncentráció függvényében: 
- Regionális klaszter: előnye, hogy a különböző ágazatok szereplőinek egymás melletti müködéséből származó pozitív hatásokat felerősíti az innovációs rendszerek és az értéklánc-rendszer megerősítésével.

- Vertikális klaszter: általában zártkörü hálózat, ahol a résztvevők azonos, illetve kapcsolódó, támogató ágazatok szereplőiből kerülnek ki.

- Horizontális-tudásorientált klaszter: nyitott, elsősorban tudás és tapasztalat cserét lehetővé tevő együttmüködés a különböző térségek, szervezetek és ágazatok szereplői között.

- Horizontális-intézményre épülö klaszter: a szervezetek létrehoznak egy szolgáltató központot, vagy szakmai szervezetet, amely elösegíti a vállalkozók közötti együttmüködést, a méretgazdaságosság szempontjait figyelembe véve.

A fenti szempontok alapján és a helyi résztvevők, aktív civil szervezetek, profit orientál szervezetek és önkormányzatok bevonásával szeretnénk egy olyan klaszter létrehozni mely az Érmelléket és a Nyírséget lefedi tevékenységével. A feladat: gazdaság- és térségfejlesztés, vagyis civil szervezetek képviselöit és helyi szinten aktív személyeket szeretnénk bevonni az akciókutatásba és a konkrét fejlesztési folyamatba, akik magukénak érzik a térség problémáit és nyitottak arra, hogy fejlesszék a térséget.

A kutatás alapjaként a következő megfogalmazást adnánk a hagyományos klaszternek: egymáshoz kapcsolódó tevékenységet végző intézmények, személyek együttmüködése melynek adott célja van és mely területileg jól lehatárolt tért jelent, viszont a klaszter tevékenységeinek hatása kiterjedhet, nem csupán a földrajzi térre ahol tevékenykedik, hanem akár regionális, nemzeti vagy nemzetközi térre is.

A kutatás folyamán olyan klasztert szeretnénk létrehozni, mely a határ menti régiót fedi le, tevékenysége erre a térre terjed ki, viszont olyan tevékenységeket hajthat végre, melyek nem csupán saját térre hatnak ki. Ha sikerült ilyen, 
expanzív természetü klasztert létrehozni, akkor ez az intézmény nemzetközi pályázatokban, együttmüködésekben is részt vehet, ezáltal nem csupán a saját terét fejleszti. Nemzetközi téren viszont jó példáként, úgynevezett "goodpractice"-ként tud megjelenni az Európai Uniós szinten. Kezdeményezésünk innovatív jellege abban rejlik, hogy a klaszter nem csupán egy országban müködő civil szervezeteket érint, hanem romániai és magyarországi civil szervezeteket, helyileg aktív személyeket tömörít.

A kutatás területe a négy román és magyar határ menti megye. Annak érdekében viszont, hogy a civil szerveződést és a társadalmi tőkét vizsgáljuk, egy szükebb kutatási teret választottunk ki, mely a lenti térképen látható. A piros vonal bal oldalán húzódó települések civil szervezetei kerültek elemzésre. Az elemzés fó eszköze a statisztikai adatok vizsgálata volt, és számos adatsor lekérdezésében segítségünkre voltak a helyi szereplők, a civil szervezetek vezetői, szakértői.

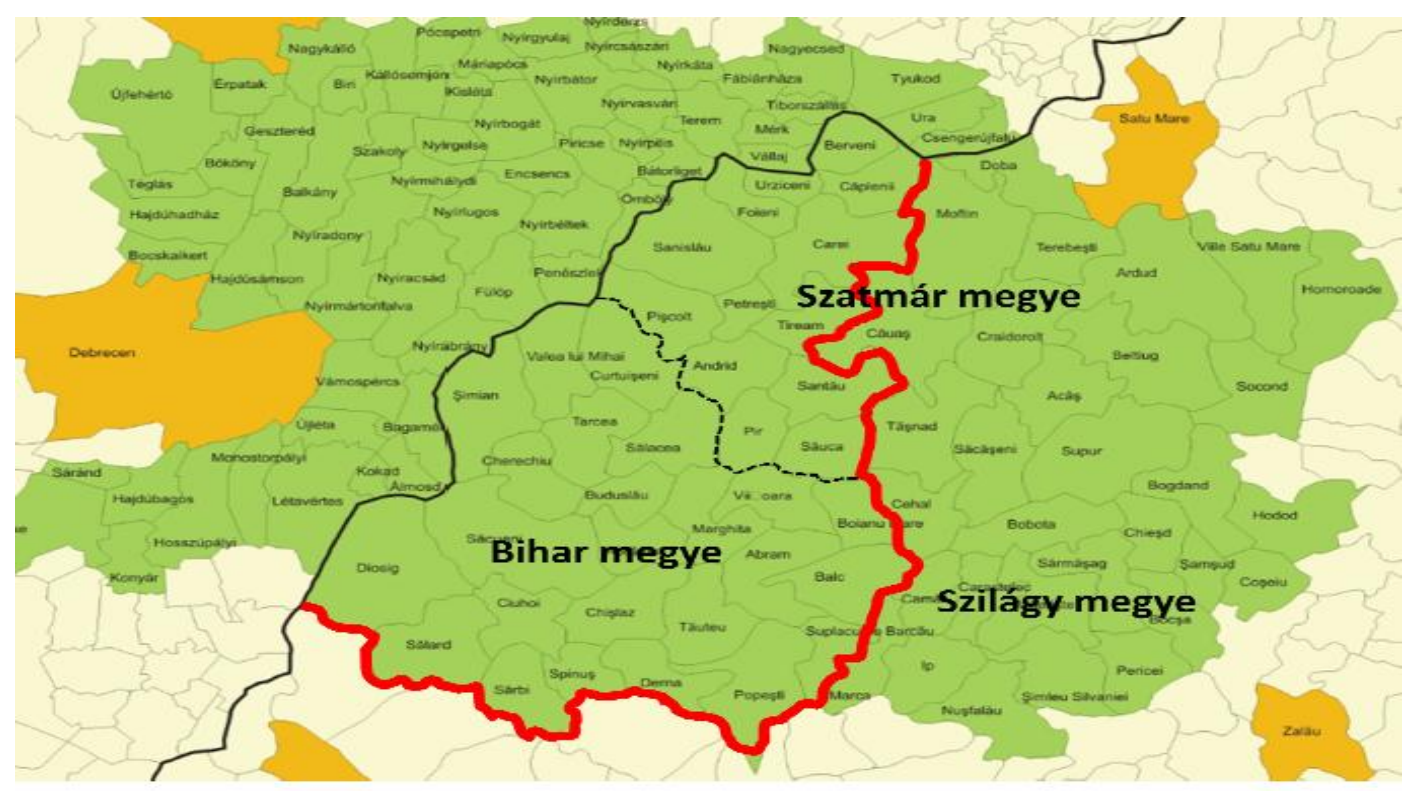

1. Térkép: A szükebb kutatási terület lehatárolása (forrás: www.nyiradony.hu ${ }^{6}$ )

${ }^{6}$ A kutatás egy része a „Frontier-value” Román-Magyar Határon Átnyúló együttmüködési program keretében valósult meg. A Civil Klaszter megalakításában, mint szakértő, az Európai Területi Együttmüködési Csoportosulás igazgatójaként vettem részt, és jelenleg is a megbízottja vagyok a klaszter müködésének és fejlesztésének. 
A Civil Klaszter létrehozásánál első lépésként felmérésre kerültek mind a magyar, mind pedig a román oldalon az alábbi térkép szerinti településeken bejegyzett nonprofit szervezetek. Az adatokat az önkormányzatok meglévő nyilvántartásaiból, valamint az országos civil szervezetek jegyzékéből szereztük. A kataszterben a következő adatokat gyüjtöttük össze: a magyar és román civil szervezetekről: szervezet neve, elérhetőségei (telefon, fax, e-mail), fö tevékenysége. Annak érdekében, hogy a társadalmi tőkét vizsgáljuk, nem csak a civil szervezetek kataszterének elkészítését és ezen szervezetek tevékenységeinek vizsgálatát tartjuk fontosnak, hanem a gazdasági szervezetek, a for-profit szervezetek vizsgálatát is.

A klaszter létrehozása a kutatási munka egyik tevékenységeként nem egyszerủen egy részvételi kutatási módszer, hiszen a klaszter hatékony müködése a klaszter tagok számára is számos előnyt jelenthet, hozzájárulván a térségbeli szerepük megerősítéséhez is.

A klaszter akár még az Európai Unió szintjén is egy elismert szervezetté válhat a jövőben, mely új piaci, szolgáltatási, árusítási lehetőségeket nyújthat tagjai számára, és ezáltal az egész térség fejlődését alapozza meg.

\section{Célcsoport behatárolás:}

Célcsoport alatt azon szervezetek csoportját értjük, akik

a) hasonló problémákkal/témákkal szembesülnek,

b) felismerik, hogy ezek valós problémák, fontos témák,

c) és arra szerveződnek, hogy ezeket a problémákat megoldják, adott témákban megfelelő mennyiségü és minőségű információval rendelkezzenek.

A célcsoportok pontos azonosítása a különböző klaszter tevékenységek meghatározása, megszervezése esetében kulcsfontosságú feladat, hiszen a település, illetve a térség versenyképessége függ az önkormányzati szervezetek 
informáltságától, illetve a helyi civil és gazdasági szféra gazdasági potenciáljától, valamint attól, hogy az önkormányzat, az EGTC, illetve a Civil Klaszter szervezeteinek céljait ismerik-e, mennyire tudnak azonosulni velük, és együttmüködni a megvalósításuk során.

A klaszter kialakításának első lépese az volt, hogy minden településre kiküldtünk egy levelet, melyben kértük a települések vezetőit, hogy segítsék a kapcsolatfelvételt a helyi civil szervezetekkel. Meglévő adatbázisaink szerint a térségben a civil szervezetek száma jelentős. A román kutatási térségben összesen 170 civil szervezet van bejegyezve, míg a magyar részen összesen 883. Meglévő információink alapján a román részen az egyesületek és alapítványok a következőképpen osztódnak meg településenként:

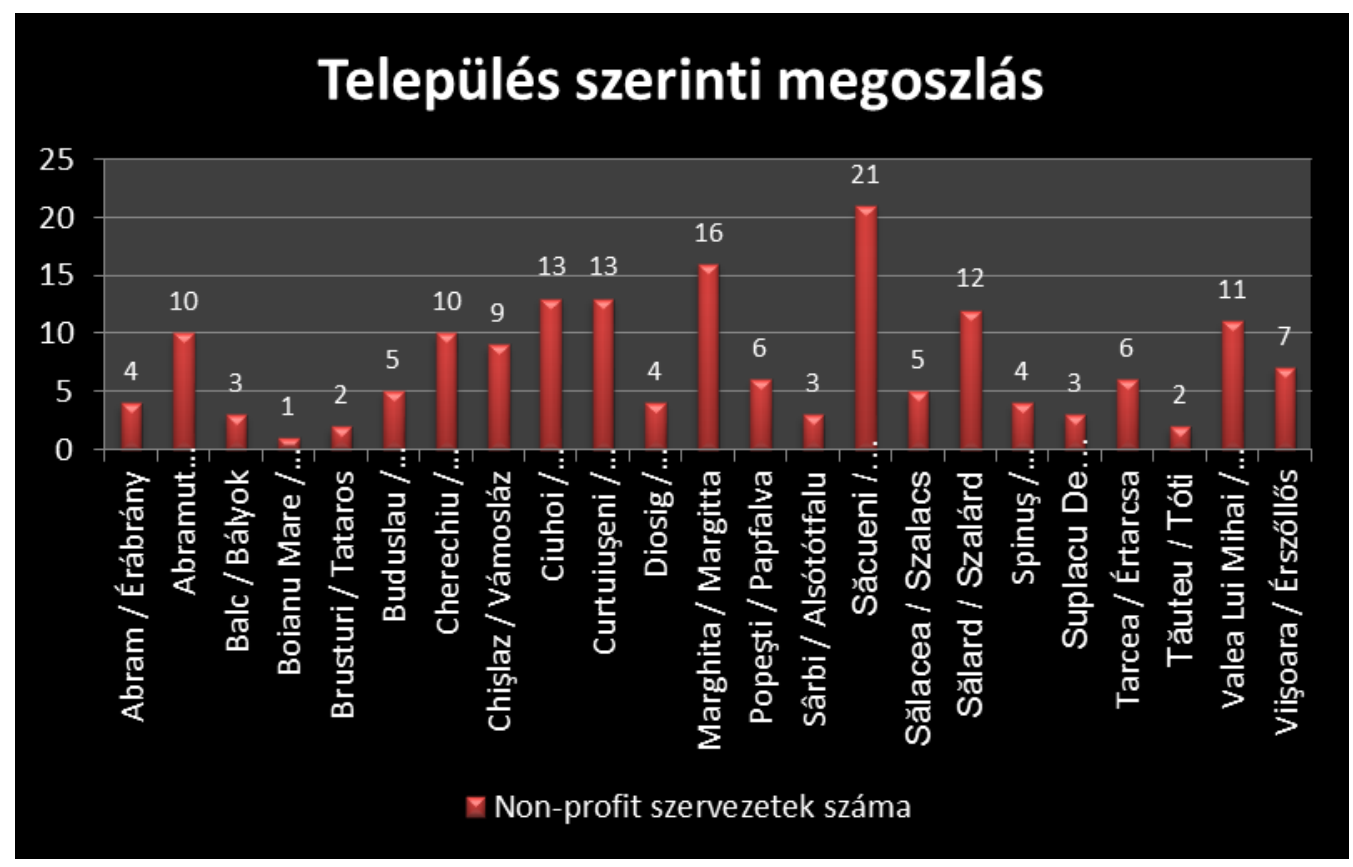

1. ábra: Civil szervezetek száma az Érmelléken (saját szerkesztés a

Romániai Igazságügyi Minisztérium adatai alapján)

A fenti ábrán látható, hogy a legtöbb civil szervezet Székelyhídon található. Jelentős még a civil szervezetek száma Margittán, Érkörtvélyesen, Berettyócsohájon és Érmihályfalván is. Egy érdekesség - ami kitűnik az adatok 
elemzéséből -, hogy a legkevesebb civil szervezet a kisebb, elszigeteltebb községekben van, míg a kisvárosokban a civil szervezetek száma magasabb.

Egy másik érdekesség a román részen, hogy a civil szervezetek többsége egyesületként lett bejegyezve, tehát alacsony az alapítványok száma. Ennek egyik fó oka az lehet, hogy a román jogi szabályozás - a 2000. évi 26. Kormányrendelet, mely a civil szervezetek bejegyzéséről és müködéséről szól elöírja, hogy egy alapítvány bejegyzéséhez egy bankszámlára - a jövőbeli alapítvány bankszámlájára - el kell helyezni összesen 100 havi átlagbérnek megfelelö összeget. Ez egy igen magas összeg, viszont egy egyesület bejegyzéséhez mindösszesen egy havi bruttó havi átlagbér értékét kell elhelyezni egy bankszámlára.

A települési besorolás után próbáltuk a román részen müködő szervezeteket tevékenységük alapján besorolni. A legtöbb civil szervezet - mindösszesen 65 szervezet - az emberi jogok terén lett bejegyezve. Ezt azt jelenti, hogy az Alapszabályban az emberi jogok védelmét fogalmazta meg fö célként. Ezen szervezetek bejegyzése föként a '90-es években történt, amikor még számos nemzetközi alap támogatta az ilyen jellegü tevékenységeket. Egy másik érdekes folyamat a '90-es évek elején Romániában a civil szervezetek bejegyzésével kapcsolatban a külföldi természetbeni adományok voltak.

Mivel számos külföldi szervezet adományokat küldött Romániába, felmerült a kérdés, hogyan lehetne ezen adományokat adómentesen az akkori vámrendszeren keresztuil behozni Romániába. Ez az oka annak, hogy számos szervezet lett bejegyezve, amelyek napjainkban már nem is tevékenyek, nem müködnek, ugyanis az egyetlen céljuk az volt, hogy adómentesen tudjanak személyautókat és különböző javakat a határon áthozni. Ugyancsak ez az oka annak is, hogy számos ilyen civil szervezet nem rendelkezik saját irodával, székhelyük az alapító lakcímén található. Tehát az ilyen jellegü szervezetek még aktívként jelennek meg a Romániai Igazságügyi Minisztérium adatbázisában, viszont nincs 
semmiféle tevékenységük és emiatt a civil klaszterben sem tudnak szerepet játszani. Ez az oka annak, hogy a román részen igen alacsony a résztvevő szervezetek száma.

Több meghívót, felkérést küldtünk ki a civil klaszter üléseire, viszont alacsony volt a részvétel, ugyanis csak azok a szervezetek képviseltették magukat, akik tevékenyek és folyamatos tevékenységeik vannak.

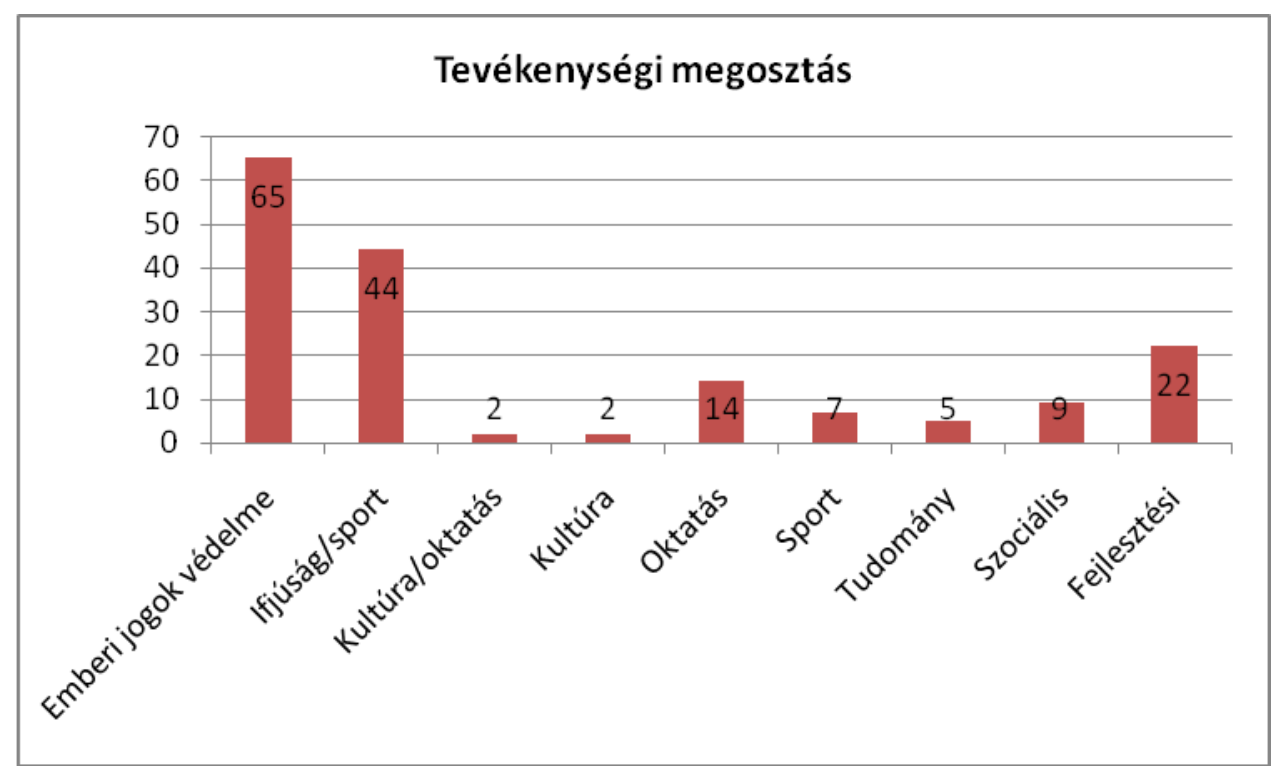

2. ábra: Civil szervezetek száma tevékenységi körük szerint az Érmelléken (saját szerkesztés a Romániai Igazságügyi Minisztérium adatai alapján)

A 2. számú ábrán látható, hogy magas még azon szervezetek száma is, amelyek ifjúsági és sport tevékenységgel foglalkoznak, és azon szervezetek száma is jelentős, amelyek helyi fejlesztéssel foglalkoznak. Az ifjúsági és sport szervezetek föként az egyházak és iskolák, valamint sport szervezetek keretein belül jöttek létre, alapítóik helyi fiatalok, sportolók és iskolai dolgozók.

Az Érmelléken minden településen megtalálható vagy intézményesülve, vagy pedig nem egy-egy sport szervezet. Az intézményesült forma a legtöbb esetben egyesület, és ritkábban alapítvány. 
A fejlesztési egyesületek legtöbb esetben a helyi polgármesterek, illetve önkormányzati dolgozók kezdeményezésére jöttek létre. Ezen szereplők felismerték azt a tényt, hogy nem csupán az önkormányzat pályázhat, illetve vihet végbe fejlesztést, hanem a civil szervezetek is fontos szerepet tudnak játszani egy település életében. Ezt a kijelentést az is alátámasztja, ha megvizsgáljuk az adatbázist, mely az érmelléki civil szervezetek listáját tartalmazza, ugyanis olyan nevü szervezeteket találhatunk, mint például „Székelyhídért Egyesület”, „Asszonyvásárai Közösségi Egyesület”, „Érmihályfalvi Fejlesztési Egyesület” stb.

A magyar részen is tapasztalható az adatok alapján, hogy a civil szervezetek száma arányos a település méretével.

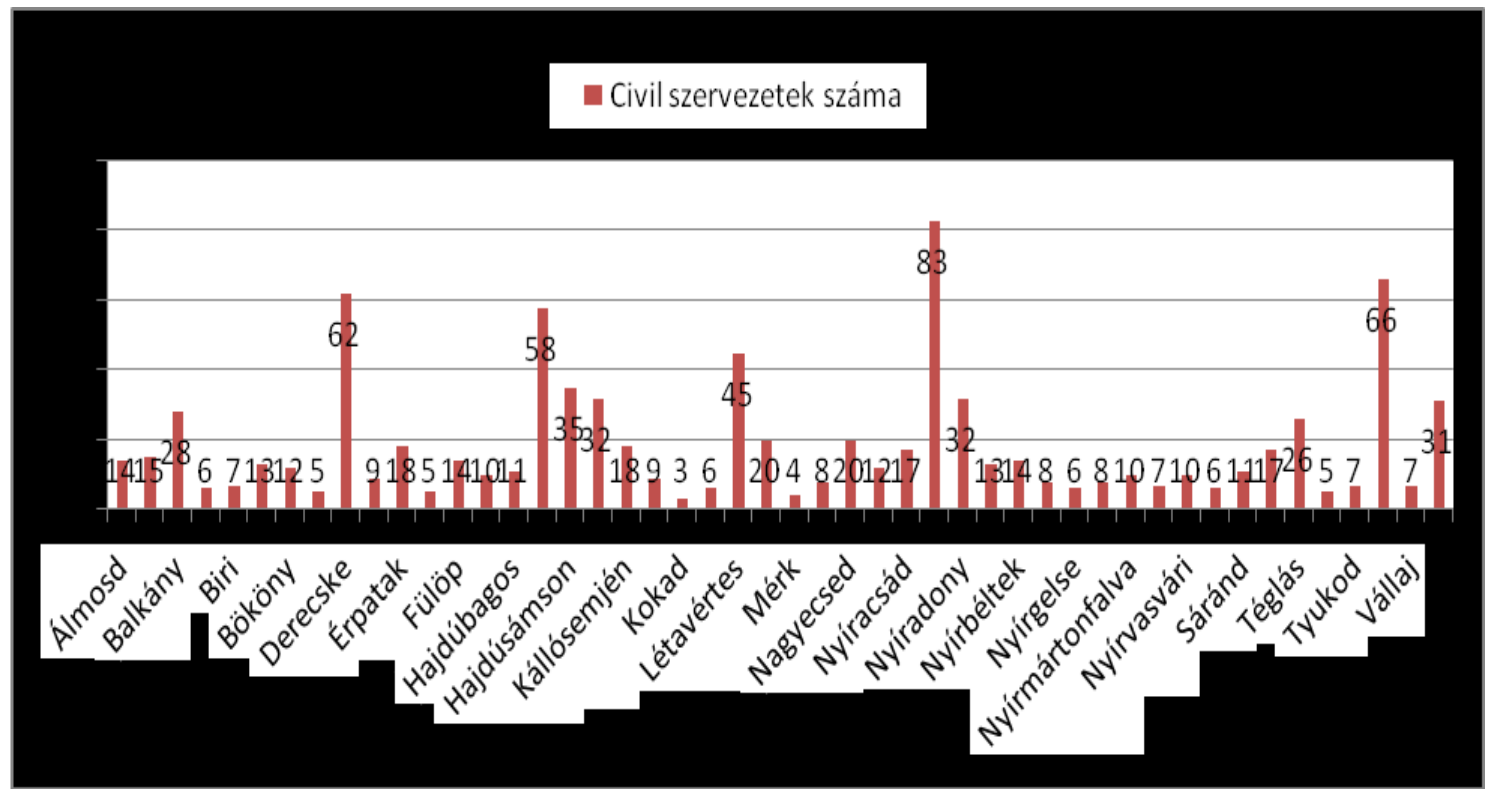

3. ábra: Civil szervezetek száma a magyarországi részen (saját szerkesztés)

A nagyobb településeken, mint például Derecskén, Hajdúsámsonban, Nyírbátorban, Újfehértón és Nyíradonyban a civil szervezetek száma magas. A legtöbb civil szervezet tehát a városokban található meg. A magyar részen igen magas a civil szervezetek száma, mindösszesen 883-at találtunk. Azonban 
hasonló folyamattal találkozunk, mint a román részen: nem minden civil szervezet tevékeny.

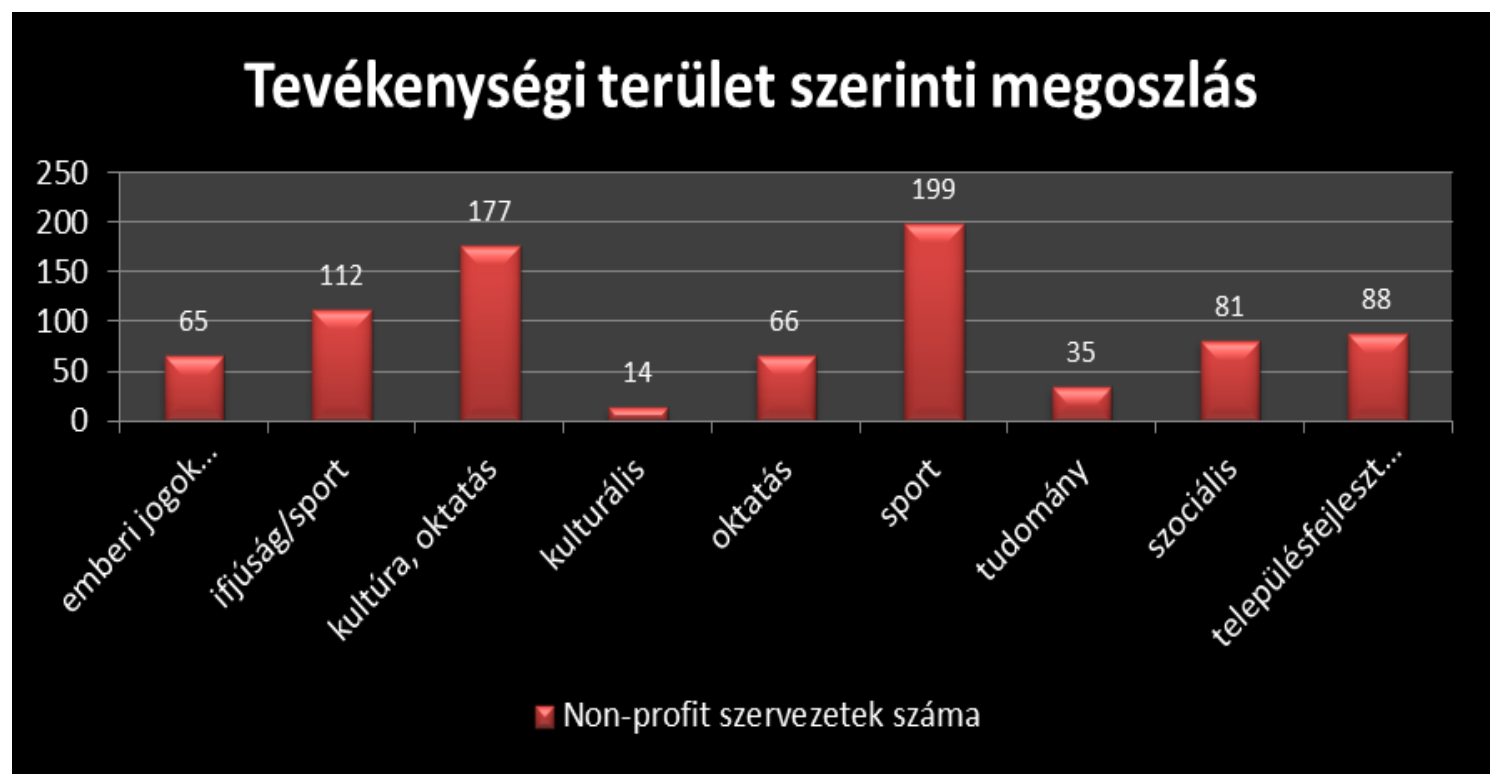

4. ábra: Civil szervezetek száma tevékenységi körük szerint a magyar vizsgálati részen (saját szerkesztés)

Megvizsgálván a szervezeteket tevékenységi körük szerint a magyar részen látható, hogy a sport, a kultúra és az oktatás terén jelentős a számuk, viszont a szociális és a fejlesztési célú civil szervezetek száma is magas. Magyarországon a sport jelen van számos településen a kézilabda, kosárlabda, labdarúgás és egyéb sportágak révén. Ezen szervezetek számos évi müködési és szakmai pályázatot valósítanak meg. Ezáltal nem csupán azért tarthatóak hasznosnak, mert szabadidős programokat hoznak be a településekre, hanem elö is teremtik ezen szabadidős, egészséges életmódot támogató tevékenységekre a pénzügyi erőforrásokat. Magyarországon több típusú nemzeti program van, mint például a TAO vagy a NEA. 
A román részen a minisztériumok nem írnak ki ilyen nagymértékü müködési és szakmai tevékenységeket támogató programokat. A román civil szervezetek fő támogatási forrásai az Európai Uniós források és a helyi önkormányzati források. Az akciókutatás fő célja az volt, hogy egy civil klasztert hozzon létre. Ennek érdekében több találkozót szerveztünk. A találkozók Székelyhídon és Nyíradonyban kerültek megszervezésre, a találkozókra a helyi önkormányzatok biztosítottak megfelelő infrastruktúrát.

A térségben müködő minden civil szervezetet meghívtunk az első találkozóra, azonban a részvétel nagyon alacsony volt. Az első két találkozóra összesen 36 civil szervezet küldött résztvevőket. Az első találkozón vázoltuk a célt a résztvevőknek: létre szeretnénk hozni egy határon átnyúló klasztert, egy olyan partnerséget, mely a térségben lévő civil szervezeteket tömöríti.

A klaszter fö feladata, hogy segítse a partnerek szakmai munkáját és megfelelö háttért nyújtson az Európai Unió által kiírásra kerülő Európai Területi Együttmúködési Program keretében.

Az első találkozón a résztvevők közös ötleteket fogalmaztak meg és az együttmüködési kereteket próbálták lehatárolni. Mivel számos önkormányzat képviselöje, valamint föként polgármesterek is eljöttek a találkozóra, a civil szervezetek képviselőivel közösen úgy döntöttünk, hogy a találkozókat különkülön témakörökben, viszont mégis közös találkozók keretében folytatjuk. Kiderült, hogy a részvételi kutatás számos meglepetéssel szolgálhat, hiszen célunk az volt, hogy egy határon átnyúló civil együttmüködést kezdeményezzünk. A kutatás közben viszont kiderült, hogy a helyi önkormányzatok képviselöi is érdekeltek a határon átnyúló együttmüködésben. A második találkozót már tematikusan hirdettuik meg, két munkacsoportot alakítván: az egyikben a közigazgatást érintő területi együttmüködést tárgyaltuk meg, míg a másikban a civil szektort érintő határon átnyúló együttmüködési lehetőségeket vázoltuk. Érdekes volt az, hogy a találkozókon kiderült, hogy a térségben számos olyan 
civil szervezet van, amely kifejezetten területfejlesztéssel foglalkozik: város-, illetve településfejlesztéssel.

Itt megemlíthető példaként a Székelyhídért Egyesület - Pro Sacueni, a Kiskerekiben müködő Asszonyvásáráért Egyesület, vagy a nyíradonyi Kincses Titánok és a debreceni székhelyü, de a Nyírségben aktív Stílus Egylet. E szervezetek képviselői részt vettek a civil és az önkormányzati szervezeti üléseken is, és számos ötlettel, javaslattal segítették közös kezdeményezésünket.

A megrendezett hat találkozó után minden résztvevő fontosnak találta, hogy az együttmüködést intézményesítsük, hogy az informális találkozó jellegböl egy magasabb szintre lépjünk.

A megbeszélések során azt az ígéretet tettem a résztvevőknek, hogy megvizsgáljuk azon intézményi kereteket, amelyek elősegítenék az együttmüködést. Minden résztvevő tisztában volt azzal a ténnyel, hogy igazán nehéz feladat megtalálni a megfelelő intézményi formát, amely mindkét országban elfogadott és megfelel a nemzeti törvényeknek. Ezen igény felmerültével a következő civil és önkormányzati klaszter találkozót két hónappal későbbre hirdettük meg, 2012 februárjára. Ebben a két hónapban megvizsgáltam a két ország törvényi előírásait és próbáltam olyan intézményi javaslatot tenni az új szervezetek létrehozására, amely megfelelne minden bevont résztvevőnek. 


\subsection{A határmentiség intézményi formái és lehetőségei}

A román-magyar határ mentén 1989 után, de föként a közigazgatási törvények „megújulását” követően, lehetőség nyílt a testvérvárosi együttmüködésekre. Mind Magyarországon, mind Romániában az önkormányzati törvény lehetővé tette az együttmüködési kapcsolatok létesítését. A határ mentén az ilyen jellegü együttműködések alapja a földrajzi elhelyezkedés volt, ezáltal föként olyan települések létesítettek kapcsolatot egymással, melyek között nem volt nagy a távolság.

Az együttmüködési kritérium másik jellemzője a gazdasági hasonlóságon alapszik, értelemszerüen a nagy városok a hasonló jellegü városok partnerségét keresték, míg a vidéki kis települések a kisebb közigazgatási szervekkel létrehozott partnerséget látták célravezetőnek. Emellett fellelhetők a véletlenszerü, ám konjunktúrafüggő kapcsolatok is, melyeknek konkrét pályázatok vagy közös rendezvények, események voltak az életre hívói. A rendszerváltást követő időszakban föként az önkormányzati együttmüködések a meghatározók, míg 1996 után együttmüködő partnerekként megjelennek a civil szervezetek is.

Martinez, O. J. (1994:1-15) közismert, határ menti együttmüködési modellje a határ menti térség jellegétől függően tipizálta a kapcsolattartási lehetőségeket. A Martinez által alkotott modell főbb jellemzőinek ismertetését követően a románmagyar határ menti együttmúködés általam felállított tipizálását is bemutatom.

Martinez négy típusra osztotta a határ menti együttmüködési kapcsolatokat, az alábbiakban a Hardi Tamás (2008:5-16) által átvett tipizálást mutatom be:

1. Elidegenedett határtérségek - az ilyen jellegü határtérségeket a feszültség jellemzi, az együttmüködések a két terület között teljesen hiányoznak. 
2. Egymás mellett létező határtérségek - csak zárt fejlesztések valósulnak meg a határ menti országok között, a határ nem teljesen zárt.

3. Kölcsönös együttmüködés - a két ország közötti stabilitás a jellemző, az országok baráti és kooperatív kapcsolatokra törekednek.

4. Integrált határtérség - akkor jön létre, ha a stabilitás erös, a két fél teljesen egyenrangú, s voltaképpen már gazdasági-társadalmi rendszerként, kvázi közös térségként fogható fel.

A magyar-román együttmüködési időszakot nem egyszerü a fenti tipizálás alapján lehatárolni, hiszen a két ország együttmüködését számos tényező, váratlan történelmi fordulat és evolúció befolyásolta, melyek hatással voltak az együttmüködésekre is. Anélkül, hogy az együttmüködést befolyásoló kritériumokat politikailag jellemeznénk, általános képet vázolnék az együttmüködés megvalósulásáról Martinez tipizálását véve alapul.
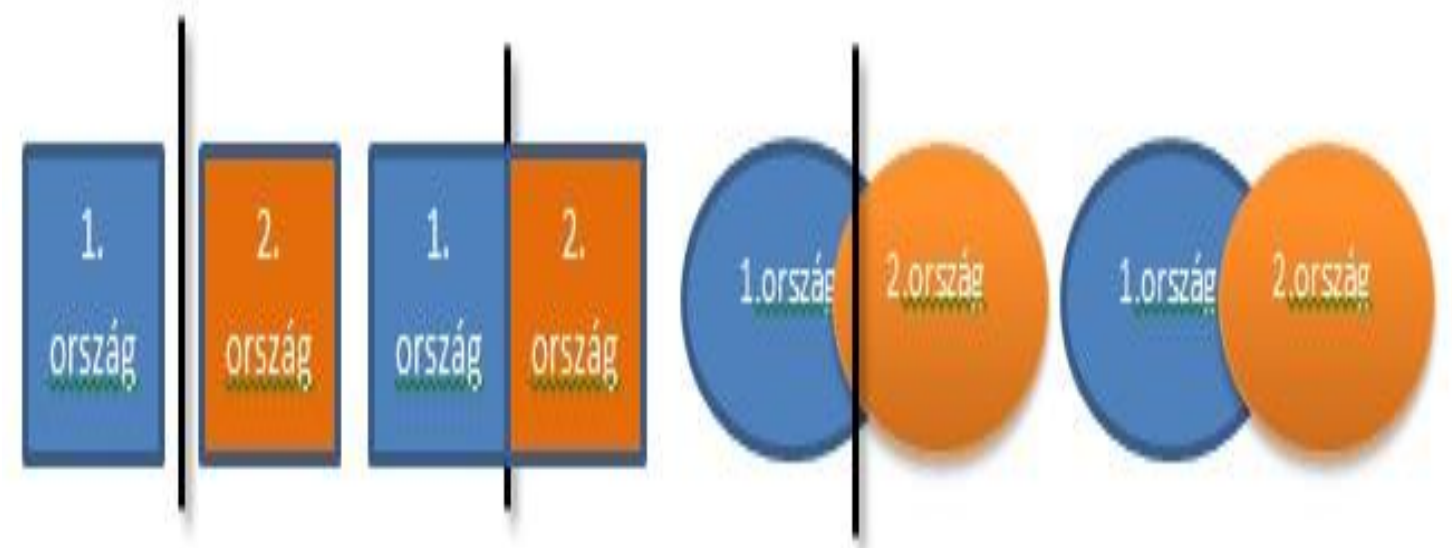

Elldegenelelt
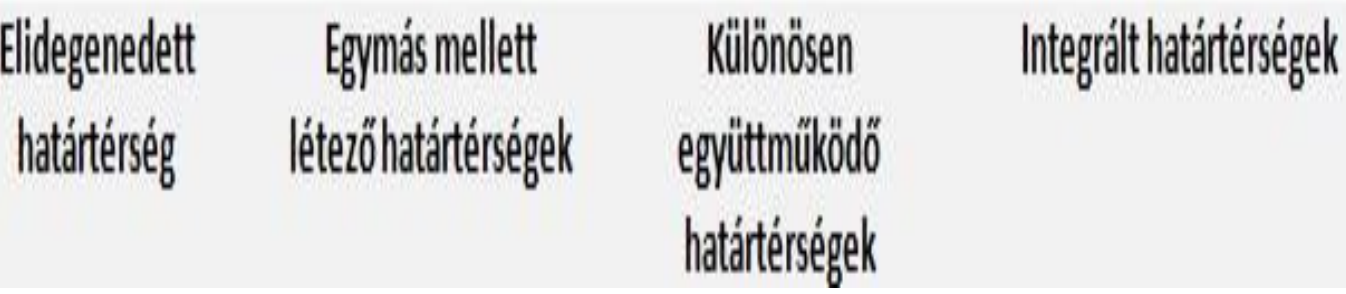

5.ábra: Az együttmüködés típusai Martinez O.J 1997 
Egyik nehézség számunkra Martinez modelljét követve a román-magyar határ menti térség karakteres jellemzőinek meghatározása, melyek közül a legfontosabbak: a szabad mozgás, vagyis a határ átjárhatóságának mértéke és az együttmüködés mértéke, színvonala, hatása stb.

Ezen kritériumokat figyelembe véve elmondható, hogy a történelem során ellentmondásos folyamat zajlott le. A határ menti lakosság, a határ menti térségben élök egy nagy egységként, a közös kultúra és hagyományok révén mindig is együttmüködtek. Baráti kapcsolatok és közös múlt jellemezte az együttmüködést, viszont állami szinten, főként bizonyos politikai döntéseket követően az 1920-as trianoni békeszerződés következtében nyilvánvaló, hogy az országok között ellenséges viszony alakult ki. Tehát míg a határ menti térségben „kölcsönös együttmüködés” mutatkozott, addig állami szinten az „elidegenedett határtérség” jellemzői domináltak. A két ország lakossága közti kapcsolattartás jogi formáját az ún. „kishatárforgalom” jelentette.

Romániában számos bank és vállalat müködött magyar tulajdonban. A kisebbségi vállalatok, pénzintézetek ellehetetlenítését célzó román politika a harmincas évek közepén erősödött fel ismét, amikor a liberálisok újra hatalomra kerültek. A magyar pénzintézeti hálózatot az 1934-es Konverziós törvény rendítette meg. A helyzet súlyosbodott 1942-ben, amikor Antonescu marsall elrendelte minden külföldi tulajdonban lévő vállalat zárolását.

A zárolt vállalatok élére ellenőröket neveztek ki és az érintett tulajdonosok befolyó jövedelmeikkel nem rendelkezhettek szabadon, mivel azt a Román Nemzeti Bank egy külön számlájára kellett utalják. (Vincze G., 2000) Ezen történelmi adatok tükrében elmondható, hogy a két ország közötti gazdasági kapcsolat sem volt a legjobb, sőt, besorolható az „elidegenített határtérség” jellegü együttmüködés kategóriájába is. 
A második világháború után mindkét országnak számos kihívással és konfliktussal kellett szembenézni. A két ország kapcsolatának elemzésében figyelembe kell venni az országok regionális jellemzőit is, hiszen nem kell elfelejteni, hogy fölöttük egy szövetségi „hálózat” uralkodott, mégpedig a Szovjetunió, amelynek fö célja a status quo megőrzése volt a határok érintetlensége és az ország belső stabilitása érdekében.

A magyar-román kapcsolat egyik érdekes momentuma Kádár János 1975-ben Helsinkiben elhangzott beszéde, melynek a fö üzenete a trianoni békeszerződés aláírásának minősítése volt. A politikai és történelmi változások tükrében megállapítható, hogy a Martinez-féle tipizálást nem lehet a Ceauşescu-rezsim politikai döntéseire alkalmazni.

A '90-es években már a „kölcsönös együttmüködés a jellemzö”, egyre átjárhatóbbak a határok, elhárulnak a határ menti térségben az együttmüködést akadályozó fizikai tényezők. Egyre erőteljesebb a két ország vezetői szintű egyeztetése, különböző megállapodások, keretegyezmények lépnek hatályba, melyek nem csak a határok átjárhatóságát segítik elö, hanem a közös gazdaságfejlesztést is.

Mivel Magyarország 2004-ben és Románia 2007-ben csatlakozott az Európai Unióhoz, minden feltétel adottá vált annak érdekében, hogy „integrált határtérségről” beszélhessünk. Ennek azonban egyik fő feltétele az volna, hogy a Martinez által megfogalmazott kritériumok mindegyike egyazon időben teljesüljön. Martinez kritériumai közül ez idáig a következők teljesültek: erős és permanens stabilitás a jellemző, a felek egyenrangúak, egyelőre azonban nem beszélhetünk a román-magyar határ menti térség gazdasági-társadalmi rendszerként való megjelenéséről. Egyelőre - bár a meglévő feltételek nem annyira szigorúak, mint a csatlakozás előtt - a határ mint elválasztó fogalom létezik. Tehát a közös gazdasági-társadalmi rendszer kialakítását nagyban befolyásolja a határ fizikai megléte. 
A határon átnyúló együttmüködések egyik ,intézménye” az eurorégió. Már 1958ban megalakult az első eurorégiós kezdeményezés a holland-német határon. Jelenleg az eurorégiók száma közel 250, azonban nehéz meghatározni, hogy pontosan hány ilyen kezdeményezés van, mivel folyamatosan alakulnak, szünnek meg, olvadnak össze. Az eurorégió egyik legnagyobb hiányossága, hogy müködésére nincs egy tagállami szinten elfogadott közös intézményi javaslat (főként civil szervezetként jegyzik be), és jogi hatáskörük nem fedi le csak az adott országot, ahol bejegyezték.

Az együttmüködések, illetve az Európai Uniós források lehívását elősegítő kezdeményezés volt 1997-ben a Régiók és Városok Első Európai Csúcsértekezletén az ún. NUTS-rendszer kialakítása. E rendszer révén egész európai uniós szinten, egységes elven alapuló, a támogatások befogadására képes intézményrendszernek kellett volna megteremtődnie.

Viszont a régiók szerveződése nem bottom-up, vagyis lentről felfelé szerveződő kezdeményezés volt, hanem top-down jellegü, vagyis fentről lefele irányított, ugyanis a tagállamok a brüsszeli elöírásoknak megfelelően hozták létre a régiókat. Tehát ez a kezdeményezés nem támogatta azt sem például, hogy a magyar-román határ menti megyék közösen egy régióban egyesítsék fejlesztési szándékukat.

Az EGTC rendelet megalkotása áttörést hozott az együttmüködések intézményi lehetősége terén. Ocskay Gy., Csetnek T. (2012:Konferencia Paper Nagyvárad) az Európai Területi Együttműködési Csoportosulás, az EGTC (European Grouping of Territorial Cooperation) következö típusait különbözteti meg:

1. Határ menti területfejlesztési EGTC-k, melyeknek célja a hosszú távú területi együttmüködés, közös fejlesztések megvalósítása és a fejlesztések eredményeinek fenntarthatóságát biztosító közös intézmények, esetleg közös vállalkozások létrehozása, müködtetése. Ezeket az EGTC-ket az eurorégiós együttmüködések következö generációjának tekinthetjük, mivel 
az eurorégiók, eurodisztriktek és egyéb szervezeti keretek között elindított munkát emelik egy magasabb szintre. Érdekeltségük széles körü lehet a turizmustól a közösségi fejlesztésen, közlekedésen át a vállalkozói együttmüködés támogatásáig. Legtöbbjük mindhárom gazdasági ágazatot együttesen is felvállalja.

2. A hálózati EGTC-k esetében nem a területi közelség, hanem a közös érdeklődési kör a meghatározó. A hálózatban együttműködő partnereket a közös program vagy projekt témája köti össze. Ez az együttmüködési forma hatékonyan alkalmazható transznacionális vagy interregionális projektek megvalósítására és eredményeinek hosszú távú fenntartására. Eddig két hálózati EGTC-t jegyeztek be Európában, mindkettő a mediterrán térség egymástól távol fekvő, de kulturálisan mégis valamiképp összetartozó entitásait fogja egybe. A közép-európai térségben is alakulóban van egy hálózati EGTC, amelynek célja egy európai észak-déli közlekedési folyosó kialakítása, az ehhez kapcsolódó tervezési, fejlesztési feladatok ellátása. A programozási EGTC egy adott uniós finanszírozási programirányító hatóságának feladatait látja el, és közvetlenül szerződést köthet a kedvezményezettekkel a konkrét projektek megvalósítása érdekében. Eddig egyetlen ilyen EGTC alakult, a Grande Région, ez a belga-luxemburgi-német-francia határtérségben menedzseli az ottani CBC-program megvalósítását.

3. A projekt EGTC-k révén a partnerek konkrét, határokon átnyúló projekteket valósíthatnak meg. Az EGTC ilyenkor projekttársulásként müködik. Erre a típusra is egyetlen példa említhető, a spanyol-francia határon egy közös kórház létrehozását célul kitüző Cerdanya EGTC.

Az elvégzett magyar és román jogi elemzések után elmondható, hogy a közös civil és önkormányzati intézmény létrehozásában a kiinduló pont az volt, hogy 
mindkét ország Európai Uniós tagsággal rendelkezik. A részvételi kutatás egyik fontos kérdése, hogy milyen intézményt javaslunk létrehozni a kutatásban résztvevő személyeknek, hiszen a kutatás eredménye nagyban befolyásolhatja a térség fejlesztését. A közös civil és önkormányzati szervezetnek a következő feltételeknek kell megfelelnie, amely kritériumok részben a résztvevők által lettek megfogalmazva, részben a vonatkozó román és magyar jogi szabályozások eredményeként születtek meg:

- a két szervezetnek úgy kell megjelennie, hogy képes legyen fejlesztéseket, kezdeményezéseket indítani a határ mindkét oldalán, és képesnek kell lennie ezen fejlesztések alapját képező intézmények létrehozására és müködtetésére

- a két szervezet intézményi kapacitásának annyira fejlettnek kell lennie, hogy képes legyen a térségbe többletforrásokat bevonni

- a civil és önkormányzati szervezetnek egy közös menedzsment koordinációja alatt kell müködnie

A jelenlegi jogi környezetet elemezve a megfelelő intézményi struktúra, amely a fenti kritériumoknak is megfelel, az Európai Területi Együttmüködési Csoportosulás ${ }^{7}$. Az ETT célja, hogy a térségben fejlesztéseket kezdeményezzen és hatékonyan járuljon hozzá a határ negatív hatásainak csökkentéséhez.

Az ETT Rendelet egyik előnye - és ezért is javasoltuk a résztvevőknek, hogy ETT-t alakítsanak -, hogy az ilyen jellegü intézmények létrehozására és müködtetésére nem kell a magyar és a román államnak egyezményt vagy

${ }^{7}$ EGTC: European Grouping of Territorial Cooperation (Európai Területi Együttmüködési Csoportosulás). A magyar törvényi szövegkörnyezetben az ETT is használatos, a rövidítés jelentése Európai Területi Társulás. A jelen dokumentum további részeiben az EGTC rövidítést használjuk. (AZ EURÓPAI PARLAMENT ÉS A TANÁCS 1082/2006/EK RENDELETE (2006. július 5.) az európai területi együttmüködési csoportosulásról) 
megállapodást kötnie, hanem a Rendelet alapján és a székhely szerinti tagállam jogrendszerét figyelembe véve kell létrehozni a közös magyar-román intézményt. A Közösségi Stratégiai Irányelvekben (Kohéziós politika a növekedés és a foglalkoztatás támogatására: közösségi stratégiai iránymutatások a 2007-2013 között időszakra) 2005-ben megjelenik szükségletkent, hogy az európai területi együttmüködés mint az Unió célkitüzése eröteljesebben kell megjelenjek a területi fejlesztési politikákban. Ennek érdekében több új közösségi jogszabálytervezett készült el. Ezek közül az egyik a Határ menti Együttműködés Európai Csoportjairól szóló rendelettervezett volt (European grouping of Crossborder cooperation, EGCC), mely a végső elfogadásra új nevet kapott „Európai Területi Együttmüködési Csoportosulás"-ra (European grouping of territorial cooperation, EGTC).

Az EGTC-ről szóló 1082/2006/EK rendeletett 2007. augusztus 1-ben lett hatályos és közvetlenül alkalmazandó az EU tagállamaiban. Az EGTC rendeletet együttdöntési eljárással szavazta meg a Tanács és a Parlament (állásfoglatások lettek kikérve a Régiók Bizottságától és a Gazdasági és Szociális Bizottságtól). Az EGTC rendelet egyike az öt kohéziós politikát szabályozó rendeletnek (általános, ERFA, ESZA, Kohéziós Alap, EGTC).

A kutatás első hipotézise, melyet a civil szervezetek bevonásával, több találkozó megszervezésével, valamint statisztikai adatok elkészítésével vizsgáltunk, a következő volt: a magyar-román határ mentén számos gazdasági és fejlődési lehetőség van, viszont a társadalmi tőke mértéke alacsony, így a határ mentén lévő területek nem fejlődnek, melynek feltételezésem szerint a fő oka az, hogy alacsony a társadalmi tőke. Feltételezhető, hogy a társadalmi tőke növelésével, a civil társadalom megerösödésével új fejlesztési irányokat kaphatna a térség.

A kutatás eredményeként elmondható, hogy a civil szervezetek száma magas a térségben, viszont ez nem feltétlenül jelenti azt, hogy e civil szervezetek hozzá tudnak járulni a társadalmi tőke növeléséhez. Számos civil szervezet nem folytat 
valós tevékenységet, bejegyzésük óta nem bonyolítottak programokat, nincs alkalmazottjuk, nem rendelkeznek irodával, valamint megfelelő pénzügyi háttérrel. Elmondható viszont, hogy a vizsgált településeken vannak aktív és tapasztalt civil szervezetek is.

A megszervezett találkozókon magas volt a részvétel és sikerült a civil szervezetek képviselöivel közösen aláírni egy megállapodást, melyben a partnerek feladatokat vállaltak, valamint arra kötelezték el magukat, hogy egy közös civil klaszter szervezetben folytatják az együttmüködést. 2013. január végére sikerült elökészíteni a partnerekkel közösen a Müködési Szabályzat és a közös cselekvési tervet, mely alapja lesz a jövőbeli közös fejlesztési tervnek.

Egy másik eredménye a kutatásnak, mely véleményem szerint igazolja az első hipotézisünket, hogy a partnerség által létrehozott klaszter első pályázati ötlete a Közigazgatási és Igazságügyi Minisztérium figyelmébe került. A pályázat címe „Ifjúsági civil háló létrehozása a Duna menti országokban”. A pályázat kidolgozása folyamatban van, viszont az első verziója befogadásra került a KIM Területfejlesztési Főosztálya által, és mint Magyarország egyik kiemelt projektjeként fog megjelenni a Duna Stratégiához készülő Operatív Programban. A projekt keretében olyan tevékenységekre kerül sor, amelyek a Duna régióban erősíthetik a határon átnyúló együttmüködést és az itt élő nemzetek közötti együttmüködést.

A pályázatba bevont partnerek civil szervezetek Magyarországról, Ukrajnából, Romániából, Horvátországból, Szlovéniából, Szerbiából, Szlovákiából és Csehországból. A résztvevők föként ifjúsági szervezetek képviselői lesznek, viszont vannak olyan partnereink is, akiknek fö célja a közösségi fejlesztés, és a szervezeten belül müködtetnek ifjúsági szekciót. Fontos ezen szereplök találkozója, hiszen a szakmai találkozón kitérünk a közös pályázati lehetőségekre is (Magyarország-Románia-Ukrajna-Szlovákia ENPI Program, MagyarországRománia, Magyarország-Szlovákia, Magyarország-Szerbia Határon Átnyúló 
Együttmüködési Programok, Youth in Action (Fiatalok lendületben) - nemzetközi együttmüködési prioritása, South-East Europe - Délkelet-Európai Együttműködési Program, Visegrád Alap stb.).

A pályázat tehát nem csak egy közös, a Duna Régióban lévő hálót/klasztert hoz létre, hanem számos településen fejlesztési lehetőségeket nyit meg azáltal, hogy a civil szervezeteknek lehetőséget biztosítunk megismerni ezeket a pályázatokat, valamint közös pályázati adatlapokat generálunk. Ezt követően a közös találkozón is partnerségi lehetőségek nyílnak meg a résztvevők előtt (ebben nagy segítség lesz az online civil adatbázis is, amelyben a civil szervezetek elérhetőségei lesznek feltüntetve). Ezáltal a pályázat közvetett célcsoportja kiterjedt és magában foglalja több száz település lakosságát.

Ha a kutatás kiindulópontját nézzük, amikor a térségben minden településen voltak civil szervezetek, viszont nem volt köztük semmilyen együttmüködés, és a jelenlegi állapotot vizsgáljuk, mely egy erős partnerséget jelent - megszervezett találkozókkal, melyeknek eredménye már kidolgozott pályázati adatlapok, sőt elfogadott pályázati ötlet -, úgy véljük, hogy kutatási kérdésünkre igazolást nyertünk. Tehát a civil szervezetek tevékenysége, partnersége befolyásolja a társadalmi tőke alakulását. Viszont ami látható volt a saját részvételi kutatásunk keretében is, hogy amennyiben nem létezik egy összefogó erő, egy vagy több személy, vagy intézmény, aki összehozza a civil szervezeteket és kezdeményez, akkor a társadalmi tőke sem növekszik. Ha még tovább gondoljuk és túllépünk a területi téren, akkor elmondható, hogy az akciókutatás egyik eredménye egy konkrét fejlesztési kezdeményezés megalapozása. Tovább lehetne vinni a gondolatot és arra a kérdésre keresni a választ, hogyan volna lehetséges a gazdasági-fejlesztési problémákkal küzdő térségeket a részvételi kutatás módszerével segíteni.

A jelen kutatás célja viszont nem az, hogy a bevont országok fejlesztésért felelős közpolitikai szereplőinek adjon útmutatást, de azért fontosnak tartjuk felhívni a 
figyelmet erre a kihasználatlan fejlesztési módszertanra, mégpedig az akciókutatásra. Hiszen a mi célunk is csak az volt, hogy a társadalmi tőke és a civil szervezetek kapcsolatát vizsgáljuk egy adott kutatási térben, viszont az akciókutatás módszertanának köszönhetően olyan fejlesztéseket generáltunk a térségben, melyek a helyi szereplők által felvállalt feladatokat jelképezik és hosszú távú fejlesztések alapjait képezik.

\subsection{Határmentiség-fogalmak}

A régió fogalmának meghatározására több lehetőség is létezik. Más a régió szó értelmezése, ha egy ezzel foglalkozó régiókutató jellemzi azt, és más, ha egy laikust kérdezünk meg arról, hogy mi is az a régió.

A régió szó etimológiáját és annak történelmi kialakulását vizsgálva láthatjuk, hogy a szó már a középkorban is használatos volt, ugyanis a közismert latin „Cuius regio, eius religio" " kifejezést előszeretettel használták a nagybirtokosok és a templomok elöljárói.

A régiók meghatározásai két nagy csoportra oszthatóak: a klasszikus és a tudományos csoportra. A klasszikus meghatározások jellemzője, hogy a lakosság nagy része ezeket a meghatározásokat ismeri és használja. A régió fogalma a klasszikus meghatározások alapján a következőkkel ér fel: területegység, térség, vidék, övezet, táj, körzet. E szinonimák teljes mértékben megfelelnek a

8 „Akié a föld, azé a vallás.” 
valóságnak és lefedik a régió fogalmát, viszont a szaktudományi definíciók nagymértékben különböznek e fogalmaktól.

A tudományos meghatározások is több csoportra oszthatóak annak függvényében, hogy milyen tényezők alapján jellemzik a régiót. Megtalálhatóak például a következő típusú megközelítések: földrajzi, gazdasági, történelmi, politikai, stratégiai, fejlesztési.

A tudományos meghatározások közül az alábbiakban felsorolunk néhány elismert nemzetközi és magyarországi kutatót. Keating (1997:45-61) szerint a régiók társadalmi szerveződés térségi szintjei különbözőek, aminek rendszerében a régió mintegy közbülső egységként helyezhető el, amitől magasabb szinten nagyobb, alacsonyabb szinten pedig kisebb egységek léteznek. A regionális térről, mint területi, funkcionális és politikai kiterjedésről is beszélhetünk. A szerző szerint a régiók nem mindig öltenek intézményi formát, de ha erre lehetőségük van, akkor önálló cselekvő egységként lépnek fel, és szervezeti keretet alakítanak ki.

Napjaink sajátossága, hogy a régiók sokkal inkább saját jogú egységként lépnek fel, míg korábban a felülről való beavatkozás passzív színterei voltak. A régiók nemcsak a kormányzási struktúra részei, hanem a civil társadalom szerveződésének területei is. A régió nem természetes képződmény, hanem társadalmi konstrukció egy meghatározott politikai térben.

Horváth (2005:310-323) szerint a régió területileg homogén gazdasági-társadalmi egység, amelynek saját intézményrendszere és identitása van. Horváth szerint fontos figyelembe venni a következő tényezőket: globális folyamatok, érdekérvényesítés/etnikai szempontok, tervezés és finanszírozási képesség.

A szerző a régiók alatt egyedi sajátosságokat felmutató, valamilyen közös jellemzőket magában foglaló, s ezek alapján földrajzilag elhatárolható területi egységeket ért. A régiók létrejöhetnek politikai okok következtében, amikor egy 
adott állam területén belül az állami feladatok, a különböző közigazgatási funkciók elosztására földrajzilag elhatárolt területi egységek - tartomány, megye, járás - kialakítása történik meg. A régiók kialakulásához gazdasági okok is hozzájárulhatnak.

Forman Balázs (2000) egy többfunkciójú meghatározást vezetett be, mely magában foglalja a régió több elemét. Forman szerint a régiók jellemzője az Európai Unióban, hogy az országnál kisebbek, de mégis átfogó területi közigazgatási egységek, melyek lehetnek természetföldrajzi alapúak, történelmi hagyományokon nyugvóak, valamint kisebb körzetek összevonása után mesterségesen létrehozottak. A szerző szerint a régiók lényegi követelménye, hogy saját közigazgatással és saját anyagi forrásokkal rendelkezzenek. Elmondható továbbá, hogy a régiókat az teszi fontossá, hogy a közösségi támogatási politika célterületei.

A fentieket figyelembe véve a régió fogalmának a következő meghatározást javasoljuk: egy földrajzilag jól lehatárolt területi szint, amely az állami szint után következik, mely saját intézményrendszerrel és anyagi forrásokkal rendelkezik, és célja a gazdaság, a terület, az infrastruktúra és a társadalom fejlesztése. E fejlesztések fő eszköze az Európai Uniós támogatások, melyek a régió intézményei által kerülnek leosztásra.

A régiók számos tényező alapján alakulnak ki, illetve szerveződhetnek meg. A régiók létrejöttének az európai országokban - s egyben jogosítványaiknak is -, több változata ismert. Az első változatot a föderalista (szövetségi) államok (Németország, Belgium, Ausztria) alkotják, ahol a tartományok a történelmi hagyományok következtében nagyfokú önállósággal rendelkeznek, s „önkéntes” szövetséget alkotnak. A tartományok saját választott parlamenttel rendelkeznek, és saját jogon hoznak rendeleteket. A szövetség - a központi kormányzat - a közös ügyek szabályozását és a közös feladatok ellátását végzi. 
A régiók kialakításának a másik változata a regionalizáció: ekkor „felülről lefelé”, azaz a központi kormányzat kezdeményezésére történik meg a megfelelő önállósággal rendelkező területi egységek kijelölése. Az ún. regionalizált államokban (Olaszország, Spanyolország) létrehozott területi egységek (a régiók) meghatározott autonómiával rendelkeznek, amely a közvetlenül választott népképviseleten alapul. Törvényhozó jogköreik azonban korlátozottak, és a költségvetési (például adókivetési) jogaikat csupán a központi kormányzati szervek által meghatározott keretek között gyakorolhatják.

A „felülről lefelé” irányuló területszervezési kezdeményezés alapján az ún. decentralizált államokban (Franciaország, Portugália, Finnország, Svédország) jöttek létre régiók. Ebben az államszerkezetben számos közügyet telepítenek helyi, illetve regionális szintre, amiket vagy választott, vagy kinevezett szervekre bíz a központi állam. A származtatott jogköröket azonban vissza lehet vonni, illetve azokat különböző feltételek között mérsékelni lehet.

Végül beszélhetünk az unitárius államokról (Nagy-Britannia, Görögország, Írország, Luxemburg, Hollandia, Dánia), ahol bár teljes vagy korlátozott önállósággal rendelkező régiók nem találhatóak, viszont a helyi önkormányzatok széles körü feladatokat kapnak, amelyek megvalósításához a központi költségvetés biztosít forrásokat. A létrehozott területi egységek (a régiók) döntően tervezési-fejlesztési funkciókat kapnak, azaz egy nagyobb térség jövőbeli alakításához szükséges fejlesztések fogadásának színterei lesznek.

A regionalizáció mellett meg kell említeni a regionalizmust, mint az „alulról felfelé” irányuló területszervezési, régióalakítási kezdeményezéseket. Ezek a törekvések arra irányulnak, hogy egy-egy területi egység sajátossága, kulturálisetnikai adottságai határozottan érvényesüljenek az állam területi beosztásában. Ezek a szubnacionális szintről érkező követelések a régióalakítás s egyben a decentralizáció rendező elvei is. 
A regionalizmus a hetvenes években bontakozott ki Nyugat-Európában és számos esetben szerencsésen találkozott a regionalizációs törekvésekkel (Spanyolország, Olaszország, Belgium), így erősítette a kialakítandó régiókat, elősegítve azok lehatárolását, illetve szervezeti-intézményi rendszerének megteremtését.

Az európai integrációt a regionalizáció és a regionalizmus együttesen erősíti már a kilencvenes évek óta. Ezeknek a folyamatoknak a következménye, hogy létrejön a nemzeti határokat túllépö - szupranacionális - új szakpolitika.

A regionális politika az Európai Uniót területi szinten szemléli, s annak fejlesztését a regionális különbségek mérséklésében határozza meg, természetesen a regionális érdekek nemzetközi szintű együttmüködése révén. Európa fejlődésében a regionális, tehát az állam alatti szint szerepe felerősödik, $\mathrm{s}$ fokozatosan megkezdődik a Régiók Európájának formálódása, amelyben meghatározó tényező az Európai Unió regionális politikája.

A társadalmi szerveződés térségi szintjei különbözőek, aminek rendszerében a régió mintegy közbülső egységként helyezhető el, amitől magasabb szinten nagyobb, alacsonyabb szinten pedig kisebb egységek léteznek. A regionális térről, mint területi, funkcionális és politikai kiterjedésről is beszélhetünk (Keating, M., 1997:45-61).

a) Területi kiterjedés alapján: A régió területi mértékegységgel meghatározható tér, aminek nagysága különbözik országok között, sőt azokon belül is. Az Európai Unióban a közös regionális politika megvalósítása miatt a terület szintjeinek és nagyságának egységes rendszerü meghatározására törekszenek, amit a NUTS hivatott biztosítani. Ez a cél csak közelítőleg valósult meg. A NUTS gyakorlati alkalmazása az országokban kialakult közigazgatási egységeken, illetve azok aggregátumán alapul. Európa országaiban viszont a 
közigazgatás rendszere történelmi okoknál fogva különböző, így a régiók igen változatos területi nagyságban fejezhetők ki.

b) A funkcionális kiterjedés kapcsán le kell szögezni, hogy nehéz a régiók feladatait általánosítani. Közös elemnek a területfejlesztési funkció tekinthető. Több szakíró a gazdaságfejlesztés új modelljeiként határozza meg a régiókat, mert a korábbi állami intervenció helyett bizonyos gazdasági funkciókat a régiók gyakorolnak, mint például a foglalkoztatás, az oktatás, a szakképzés, valamint a kis- és középvállalatok támogatása. A régiók kulturális funkciót is betöltenek, különösen ott, ahol különböző etnikai közösségek léteznek.

c) A politikai kiterjedés értelmében a régió a legitim döntéshozatal színhelye, és olyan dimenzió, amit a politika szereplöi elismernek. A politikai tér létét több tényező alakítja, többek között a terület politikai érdekét is kifejező csoportok érdekérvényesítése, vagy az etnikai és a nyelvi identitás megőrzéséért indult mozgalmak küzdelmei.

A regionális fejlődés dinamikus folyamat, mely állandóan változik, hatására a régi formák átalakulnak vagy újak fejlődhetnek ki. A regionalizálódás egyik szembetűnő jelensége a régiók közötti kapcsolatok fejlődése, ami átlépi az országhatárokat. Az 1960-as évektől kezdve szaporodnak azok a területi együttmüködések, amelyek vagy közvetlenül a határ mentén, vagy a határon átnyúlva jönnek létre a régiók között. Később az együttmüködő régiók érdekeik védelmében, valamint sajátos igényeik kifejezésére nemzetközi szervezeteket hoztak létre.

Európában ez a jelenség új összefüggésbe helyezi az integráció és a regionalizáció kapcsolatát. Az integráció és a régiók fejlödése semmiképp sem egyoldalú kapcsolat: nemcsak a tagországok integrációjának és a Közösség 
regionális politikájának hatására változnak a régiók, hanem a területek közötti, alulról jövő kezdeményezés is befolyásolja az integráció alakulását. Mint ahogy az integráció új dimenziót ad a régiók fejlődésének, úgy a regionalizálódás is új hajtóeröként müködik az integráció előrehaladásában. Különösen igaz ez a kölcsönhatás az európai határ menti régiók létrejöttével és fejlődésével.

A határ menti régiókat nem lehet egyszerüen besorolni a Keating (1997:45-61) által fentebb bemutatott c. pontban elrendezett régió fogalmak közé. Mivel határokat átlépő együttműködésről van szó, ezért a jelenségnek nemzetközi vonatkozása van, de az országok területénél kisebb egységek között jön létre a kapcsolat. Ez az európai jelenség a szereplök nemzetközi tevékenységére mutat példát, ami egyébként világtendencia.

Az új jelenség problematikájával a nemzetközi politika elmélete behatóan foglalkozik. A határ menti együttmüködés több mint nemzetközi kapcsolat, mely az országok integrációját segíti, amit csak a '90-es évek kezdetétől támogat az Európai Unió.

A határ menti régiók együttműködését biztosító intézmények viszont nem jelentenek új irányítási szintet, és nem rendelkeznek több kompetenciával, mint bármelyik más régió az adott állam területén. Ezért a határrégiókat olyan területi entitásnak tekintik, mint az állami szint alatti többi régiót (Keating, M. 1997:45$61)$.

A határ fogalmának a következő alapvető funkciói vannak (Nemes Nagy J, 2005:284-286):

a) A határ mint elválasztó térelem, gát (barrier)

b) A határ mint szürőzóna, kapukkal (filter)

c) A határ mint perem és ütközőzóna (frontier)

d) A határ mint összekapcsoló elem (kontaktuszóna) 
A határ menti területek együttmüködésében Novotny (2003:2-12) nyolc olyan tényezőt nevesít, amelyek aszimmetrikus voltukból adódóan a régiók nemzetközi kapcsolatát akadályozzák.

A szerző véleményére támaszkodva az együttmüködést gátló aszimmetriákat az alábbiakban csak felsorolom, hatásukat a román-magyar határon végzett empirikus kutatásban magam is vizsgálni szeretném:

1. Népesedési, demográfiai folyamatok különbözősége az együttműködő területek között.

2. Életszínvonalbeli különbség.

3. Közigazgatási hatáskörök eltérése.

4. Érdekellentétek a célok meghatározásában és a projektek kidolgozásában.

5. Tervezési gyakorlat és módszerek különbözősége.

6. Schengeni külső határok eltérése.

7. Információáramlás problémája.

8. Nyelvi nehézségek.

A Council of Europe (2000) a következő jellemzést adta: ,a határon átnyúló régió egy a földrajzból, történelemből, ökológiából, etnikai csoportokból, gazdasági lehetőségekből stb. származtatható potenciális régió, amelyet azonban a határ két oldalán uralkodó államok szuverenitása két részre oszt.”

Egy igen gyakran használt meghatározás úgy fogalmaz, hogy a határrégió egy területi részegység és egy regionális rendszer, kiegészítve a határral és annak jellegzetességeivel. Ebböl az elméletéből kiindulva elmondható, hogy a románmagyar határ mentén kialakuló együttműködés jellegzetessége, hogy a határ 
mindkét oldalán az együttmüködés gördülékeny volt és ebben magyar-magyar és román-magyar, magyar-román kapcsolatok, pályázatok is megvalósultak. Történelmileg vizsgálva ezt a határrégiót sajátságos helyzetröl beszélhetünk, hiszen a történelmi Magyarország területe magában foglalta a jelenlegi román határ menti megyéket is.

Az integráció tetőfoka az 1990-es években volt, ugyanis történelmi fordulat következett be, amikor 1992-ben hatályba lépett a Maastrichti Szerződés. Chryssochoou szerint az Európai Uniós szerződés aláírásával valós átmenet történt a policy szintrôl az államalakulat felé a polity szintre. Véleményünk szerint az Európai Unió történelmében ezzel a szerződéssel alapműködési jellegében minőségi változások alapjai lettek megteremtve. Viszont ezek voltak az első komolyabb lépések az intézményesülés felé, az államalakulat úgynevezett pilléreinek lefektetése által.

A számos, később csatlakozó állam új kihívásokat és lehetőségeket is rejtett magában, hiszen hosszú és nem mindig akadálymentes volt az út, amíg az EU eljutott a teljes intézményi reform törvényi kereteinek megteremtéséhez, a Lisszaboni Szerződés aláírásához. Ezek után pedig bekövetkezett a pénzügyi válság, mely szorosabbá tette az országok közötti együttmüködést, és talán kijelenthetjük, hogy valójában most bizonyosodik be, hogy a gondosan és időben felépített közös intézményi rendszer, a közös európai „állami” rendszer jól működik, vagy pedig újabb intézményi reformra lesz szükség.

Visszatérvén az integráció és az EU kérdéséhez, a Jenei György által vázolt problémát szeretném előtérbe helyezni. A dilemma, amit a fent említett szerző előtérbe helyez, hogy az Európai Unió egy rendkívül ambiciózus kormányközi szervezet, amely a tagországok érdekeit közösen érvényesíti, és ezzel szélesíti a tagországok szuverenitását, vagy pedig az Európai Unió egy szupranacionális 
szervezet, amely fokozatosan át kívánja venni azokat a funkciókat, amelyeket hagyományosan a tagállamok gyakoroltak.

A dilemma megválaszolásához meg kell vizsgálnunk, melyek is voltak azok a tényezők, amelyek kiváltották az integrációs folyamatot. és persze a folyamatos intézményi fejlődésre is hatással voltak.

Mi is a fó jellegzetessége az Európai Uniónak? Nem egy tipikus államról beszélünk, hanem egy államközi megegyezésről, amely több évtized során vált egy erős entitássá. Ágh Attila szerint az európai politikai rendszerek alapvonásai a következőek:

1. Államközpontúság: fó jellemzője, hogy a központosított állam, a végrehajtó hatalom játszik domináns szerepet.

2. Parlamentarizmus: olyan államokra jellemző, ahol a parlamenté a fö hatalom.

3. Pártelvüség: a politikai élet főszereplői, a policy alternatívák megfogalmazói a pártok.

4. Polarizált értéktagoltság: hagyományosan jól tagolt bal- és jobboldali értékrend alapján szerveződő politikai erők.

5. Hivatásos politikai elit: kiemelkedett egy professzionális politikai elit, amely szoros kapcsolatban van az adminisztratív elittel.

A Madridi Keretegyezmény 2. cikk (1) bekezdésében a következő fogalmazást található meg: „... a határ menti együttmüködés fogalmába tartozik két vagy több Szerződő Fél joghatóságán belül lévő területi önkormányzatok és közigazgatási szervek között a jószomszédi kapcsolatok erősítése és továbbfejlesztése céljából megvalósuló tevékenység, valamint az e cél megvalósítását szolgáló egyezmény vagy megállapodás megkötése.” 
A Madridi Keretegyezmény 2. cikk (2) bekezdése leírja a közigazgatási szerveket is:,,...”a területi önkormányzatok és közigazgatási szervek" alatt olyan önkormányzatokat, hatóságokat vagy közigazgatási szerveket kell érteni, amelyek helyi és területi feladatokat látnak el, és az adott állam belső joga szerint ilyennek tekinthetö." 


\section{FEJEZET: TÁRSADALMI KAPCSOLATHÁLÓK A HATÁR MENTÉN ÉS AZ EGYÜTTMÜKÖDÉS FORRÁSAI}

Az Európai térbeni szerveződés, a települések közötti kapcsolatok és kapcsolati hálók elméleti és gyakorlati kérdése a jelen fejezet kutatási témája. A társadalmi, intézményi kapcsolathálók és e hálók típusai, valamint a határ menti övezetben felismerhető és használható modelljei képezik a jelen fejezet elméleti pilléreit.

A fejezet célja nem csak az, hogy elméleti szinten bemutassa azon intézményeket, amelyek befolyásolják a fejlődést és a társadalmi kapcsolatokat, hanem meg szeretnénk vizsgálni az intézményeket, amelyek a határ menti együttmüködésben részt vesznek vagy vehetnek, és így képesek befolyásolni a társadalmi tőke alakulását. Annak érdekében, hogy megismerjük e szervezeteket, megvizsgáljuk a 2004-2008 időszakban megvalósított PHARE CBC és Interreg pályázatokat, és a 2007-2013 időszakban az Európai Területi Együttmüködési Program keretében nyertes pályázatokat.

A kutatás második kérdése (H2) azt vizsgálja, hogy a közintézmények, civilek befolyásolják vagy sem a társadalmi kapcsolatháló kialakítását, és hogy a pályázatokban „mesterségesen” vagy természetesen alakultak-e ki a kapcsolatok, valamint hogy ezen kapcsolatok „konjunktúrafüggők”-e és csupán a pályázati források elnyerésére jöttek-e létre, vagy hosszú távú partnerségek alakultak ki? (H2)

A kutatási kérdés célja tehát, hogy megvizsgálja a partnerség és a pályázatok minőségét úgy, hogy közben bemutatja a támogatási forrásokat is 2004-től egészen napjainkig. Ezen területek vizsgálatával és a vizsgálat eredményei alapján lehetőség nyílik javaslatok megfogalmazására a következő pályázati időszakra a 2014-2020-as programozási időszakban.

A második kutatási kérdés megválaszolására a következő módszereket választottam: a PHARE CBC 2004-2006 időszakban megvalósított pályázatok 
vezetőit megkeressük egy kérdőívvel és a helyszínen a megfigyelés módszerével közösen alkalmazzuk. A rendelkezésünkre bocsátott pályázati adatlapokat is megvizsgáljuk, összpontosítván a pályázati eredményekre, indikátorokra és az eredmények fenntarthatóságára.

A kutatási kérdés két vonalon vizsgálható: a már lezárt pályázatokért felelős intézmények helye és szerepe a társadalmi kapcsolathálóban, valamint a jelenlegi jogi formák, intézmények, melyek elősegíthetik az együttmüködést. Célunk tehát megnézni, hogy milyen intézmények vettek részt az együttműködésben és milyen eredményeket tudtak felmutatni - konkrétan a társadalmi kapcsolati hálókra és indikátorokra összpontosítva -, viszont egy másik célunk azt megvizsgálni, hogy milyen más intézményi forma segítené elő az együttmüködést. Ha elkészültek az eredmények, akkor ezen eredmények két fórumon kerülnek bemutatásra a szük vizsgálati terünkben (a két magyar és két román megyében).

A fórumokra a kiválasztott és már az első hipotézisben is vizsgált települések polgármestereit, intézmények vezetőit hívjuk meg, és közösen próbáljuk megtalálni a választ arra, hogy milyen együttmüködési forma a megfelelő a 20142020-as programozási időszakra, mely nem csupán pályázati forrást hoz a térségbe, hanem hosszú távon megteremti a társadalmi hálózatot, mely a térségfejlesztés alapjává válhat a közeli jövőben.

\subsection{Határ menti együttmúködések és hálózatok}

Az állam politikai és területi kiterjedése nem mindig azonos a növekvő ágazati problémák kiterjedésével és hatásával. Az ágazati problémák, feladatok szorosan kapcsolatban vannak a technológiai változásokkal, fejlesztésekkel. A munkanélküliség és a gazdasági hanyatlás megfelelő példák az állami és ágazati 
kiterjedés nemzeti határokon túlnyúló hatásaira.(Elgström, Ole - Jönsson, Christer 2005:21-23.)

Sven Tagil (2000:129-144) szerint a probléma határ elválasztódik az hivatalos területi határoktól, hiszen különbségek ismerhetőek fel a belső és külső tér között, a periféria és az államközpontok között. Ez az elmélet alátámasztja a részvételi kutatásunk által választott térség indokoltságát, hiszen az Érmellék és a Nyírség egyaránt olyan hátrányos helyzetü területek, melyek távol találhatóak saját országuk központjaitól, és perifériának számítanak nem csak földrajzi elhelyezkedésük miatt, hanem gazdasági-szociális problémáik és gondjaik következtében is.

Tagil (2000:129-144) szerint egy adott területen a határ nem felismerhető, csak akkor, ha mesterséges módon van kialakítva a terület környezetében. Jonsson szerint a hálózatok úgy írják le a területet mint csomópontokat, amelyek több kapcsolati pontból, „links”-ből tevődnek össze. Elgström, Ole - Jönsson, Christer (2005:21-23) szerint a különbség a hálózatok és a terület között akkor válik szembetűnővé, amikor fontosabb hálózatok függetlenné válnak a lefedett területtel szemben, melynek van egy jól meghatározott demokratikus rendje. Ezt a saját részvételi kutatásunkban a következőképpen értelmezzük: a határ menti térség egy olyan terület, amelyet határ választ szét. Nem csak fizikai határátkelöre gondolunk itt, hanem mentális határokra is, hiszen intézményi, de lakossági szinten is a határ egy létező elem, mely szétválasztja a határ két oldalán élőket. Viszont ha az előző fejezetben létrehozott civil klaszter eredményességét vizsgáljuk, akkor egy olyan erős hálózati kapcsolatról beszélünk, amelyben román és magyar civil szervezetek vesznek részt, és közösen kezdeményeznek nemzetközi pályázatokat, tevékenységeket. Ha a saját részvételi kutatásunkhoz vesszük alapul Tornqvist elméletét, akkor elmondható, hogy az eddig létrehozott hálózatok, melyek a kutatás eredményei (az EGTC és a civil klaszter), függetlenül tudnak müködni, tehát a területi szint és különbség megszünik. 
Castells (2005: 3-23) három fő kategóriába sorolja a hálózati kapcsolatokat:

1 fizikai hálózatok

2 intézményi hálózatok

3 társadalmi-kulturális hálózatok

A fizikai hálózatok a közlekedési infrastruktúra hálózatokat jelképezik. Az ilyen jellegü hálózatok fő jellemzője, hogy egyszerüen felismerhetőek, térképezhetőek, leírhatóak. Az intézményi hálózatok nem ismerhetőek fel olyan egyszerüen, mint az infrastruktúrát megjelenítő fizikai hálózatok, viszont eredmények, együttmüködések, dokumentumok alapján leírhatóak, bemutathatóak. A legnehezebb viszont felismerni Castells (2005.373-405) szerint a társadalmikulturális kapcsolati hálókat, ugyanis a szerző szerint egyes hálók teljesen láthatatlanok a külső megfigyelők számára.

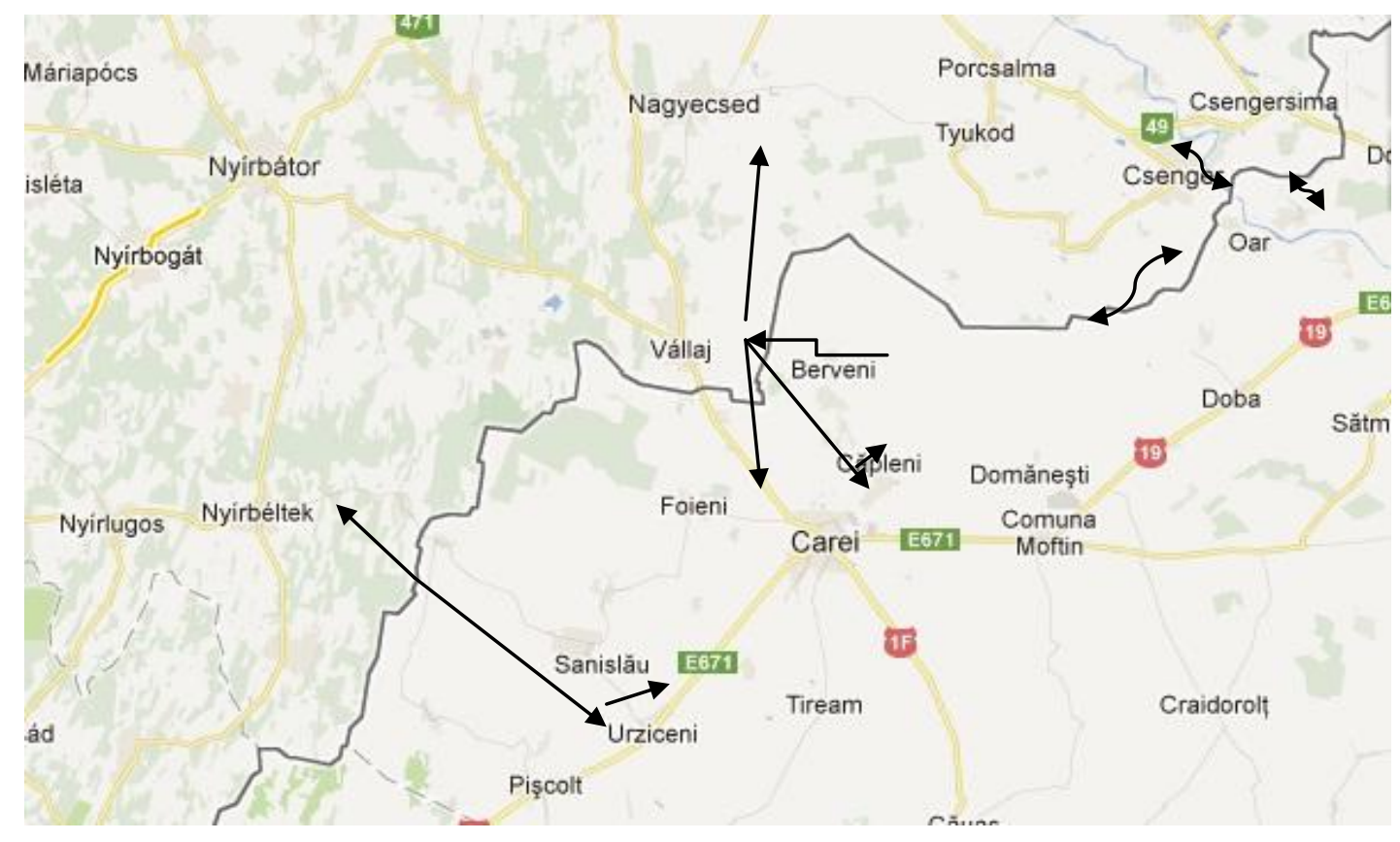

6.ábra: Fizikai hálózatok a magyar-román határ mentén (saját szerkesztés Castells modellje alapján)

Castells modellje alapján a fenti ábrán vázoltuk a határ menti területi hálózatok javasolt modelljét. Ez a modell a részvételi kutatás eredményeként jött létre, felhasználva Castells elméleti modelljét. 
A castellsi elmélet szerint a fizikai hálózatok jól lehatárolhatóak, egyszerủen térképezhetőek. Viszont a magyar-román határ mentén, konkrétan a vizsgált területünkön a közlekedési infrastruktúrák nem fedik le teljességében az egész területet.

Magyarország folyamatosan fejleszti autópálya-hálózatát. A programba bevont térséget két autópálya (M3 és M5) érinti. Az M5-ös autópálya elérte Szegedet, az M3 autópálya pedig 2007-ben érte el Nyíregyházát. 2006-ban fejezték be az M35ös autópálya Debrecenig tartó szakaszának építését. A négy magyar megyeszékhelyet a 47-es és a 4-es számú utak kötik össze. Az utak bizonyos részei jelenleg is fejlesztés alatt állnak. Román oldalon a 69-es, 79-es és 19-es számú utak biztosítják a kapcsolatot Temesvár, Arad, Nagyvárad és Szatmárnémeti között. Ezeken kívül további utak vezetnek Nagybányára és Kolozsvárra.

A közlekedési infrastruktúra kisebb elemeit illetően a határ menti térség többféle problémával küzd: míg a nagyobb települések többnyire viszonylag könnyen megközelíthetők a nagy gazdasági központokból, és megfelelő közlekedési összeköttetéssel rendelkeznek a szomszédos országok irányába, a vidéki kistelepülések sokszor nehezen megközelíthetők. Ez különösen igaz Románia esetében, ahol az utak általános rossz állapota okozza az egyik legsúlyosabb problémát.

A határátkelöhelyek hálózata megfelelö: 14 határátkelőhely található a magyarromán határon (ezek közül 4 vasúti, 1 közúti és vasúti, 9 csak közúti átkelö). A határátkelök jelenlegi hálózatának kapacitása megfelelö, de az infrastruktúra állapota és a szolgáltatási színvonal egyes esetekben nem kielégítő.

A határ menti térségben nyolc repülőtér található (minden megyeszékhelyen), ezek közül öt (Debrecen, Temesvár, Arad, Nagyvárad és Szatmárnémeti repülőtere) nemzetközi forgalmat is bonyolít. Nem jellemző, hogy ezeket a repülőtereket külföldi (vagyis Magyarországon romániai, illetve Romániában 
magyarországi) utasok kereskedelmi forgalomban igénybe vennék. (Magyarország-Románia Határon Átnyúló Operatív Program 2007-2013) Jordan és Schubert (1992:7-27) leírják a politikai hálózatok fogalmát is. A szerzők szerint e hálók jellemzőit a szereplői, a közöttük lévő kapcsolatok és e kapcsolatok határvonalai határozzák meg. Az ilyen hálók magukban foglalnak relatívan jól lehatárolt személyeket a köz- és magánszférából, akik egy jól körülírt adott területen, szakmai kérdésben, ágazatban dolgoznak. Az ilyen jellegü hálózatokban a szerző szerint a szereplőknek megfelelő információáramlási, szakértelmi és más politikai erőforrásokkal kell rendelkezniük.

Castells második hálózati fajtája az intézményi hálók. A román-magyar határ mentén több intézményi háló is felismerhetö. Mit is tekinthetünk intézményi hálónak? Véleményem szerint a magyar-román határ mentén az intézményi kapcsolatok lehetnek formálisak vagy informálisak.

A formális kapcsolatok és hálók jellemzői, hogy a helyi közigazgatások, civil szervezetek között partnerségi megállapodások, testvér települési szerződések, közös pályázatok, közös intézmények jöttek létre. Az informális hálók a nem formalizált kapcsolatok: az önkormányzatok, civil szervezetek képviselői találkoznak, részt vesznek egymás rendezvényein, fesztiválokon, város- és községnapokon, viszont nem létezik semmilyen dokumentum, hivatalos megállapodás az együttmüködésről.

A lenti, 7.számú ábrán látható, hogy a formalizált hálózati kapcsolatok több intézményi forma együttmüködéseként is kialakulhatnak. Tehát a magyar-román határ menti formális intézményi hálózatok szerteágazóak és a hálózatban részt vevő együttmüködési formák, intézmények számának növekedésével egyidejűleg nőnek a hálózati kapcsolatok is.

Véleményünk szerint az ilyen jellegü hálók müködése és átláthatósága alacsony, ezért is indokolt olyan együttmüködési intézményi formákat létrehozni, amelyek 
egy időben tudják a formális és informális kapcsolatokat orientálni, és a közös intézményeket üzemeltetni.

A társadalmi-kulturális hálózatokat nem határoljuk le a lenti ábra segítségével, hiszen e hálózati formák - ahogyan Castells is leírta -, a legnehezebben felismerhetőek, nem kézzelfoghatóak.

Az emberek közötti kapcsolatok, a tapasztalatcserék vagy egyszerü turisztikai látogatások a határ egyik oldalán élők felől a határ másik oldalán élők felé ilyen jellegü hálózati formának számítanak. Elmondható tehát, hogy a társadalmikulturális hálók résztvevői a határ menti lakosok teljes összessége, a kapcsolatok pedig szerteágazóak, hiszen lehetnek egyszerü rokoni, baráti vagy gazdasági, turisztikai jellegü kapcsolatok is.

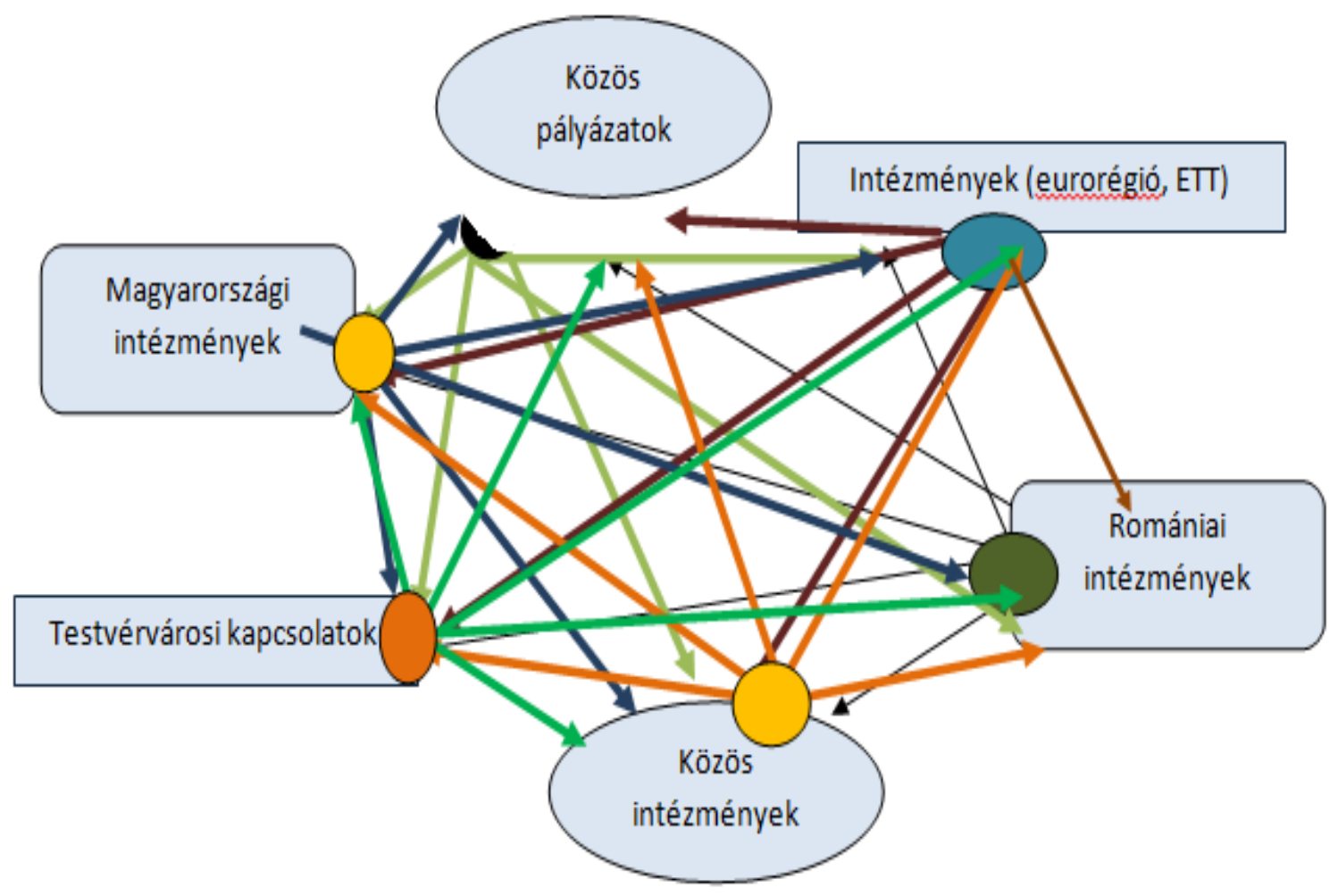

7. ábra: Intézményi hálózatok a magyar-román határ mentén (saját szerkesztés Castells (2005) modellje alapján) 
Castells gazdasági megközelítése szerint a hálózati kapcsolatok befolyásolják a gazdasági kapcsolatok fejlődését is. Véleménye szerint a XX. század végétől napjainkig olyan változások mentek végbe a gazdasági rendszerekben, amelyek a hálózati kapcsolatok fejlödésének köszönhetőek, hiszen a digitális kommunikációs csatornák megjelenésével olyan új lehetőségek adottak a társadalmi-gazdasági hálók fejlesztésére, amelyek addig nem voltak ismertek. Castells statisztikai számításokra hivatkozva úgy véli, hogy jelentős változások vannak az ipar 1975 és 1995 közötti időszakának fejlődési szintje, valamint az 1996 és 2005 közötti időszakának fejlődési szintje között.

A vizsgálat az Egyesült Államokra vonatkozó statisztikai számokon alapszik (Castells, 2005:8).

Ha a fenti kijelentést vesszük alapul és a határ menti övezetek fejlődésének szintjét próbáljuk statisztikai számok alapján mérni, akkor elmondható, hogy az „amerikai Castells-modellt” számos más tényező befolyásolja, hiszen a '89-'90es években végbement rendszerváltás nagymértékben átalakította a gazdasági struktúrát, és ezen gazdaság-politikai változások érezhetőek voltak a határ mentén is. Szóval az 1975 és 1995 közötti időszakra nem lehet egy általános kijelentést tenni, hiszen a '89-'90-es változások Magyarországon és Romániában egyaránt új gazdasági lehetőségeket, ám egy politikai átmeneti időszakot is jelentettek, a demokrácia „keresésének” útját jelentették, olyan időszakot, ahol számos törvényi és szabályozási átalakítás történt.

Az 1996 és 2005 közötti időszak valóban erőteljesebb fejlődési időszakot jelentett a határ menti térségek életében, hiszen nemcsak az intézmények közötti együttmüködés kapott új lendületet és új lehetőségeket a PHARE és INTERREG III Programoknak köszönhetően, hanem számos magyarországi gazdasági cég, magánszervezet nyitott telephelyet Romániában.

Egyidejüleg egy másik folyamat is megfigyelhetö, a magyar és román határ menti övezetekben megnőtt a vállalkozási szellem, nőtt a gazdasági szereplök száma, 
melyhez nem csak a kommunikációs hálók által nyújtott lehetőségek járultak hozzá, hanem az Európai Uniós és belső szabályozási keretek által nyújtott biztos háttér is.

A hálózatok vizsgálatában és kutatásában közismert Jacob Levy Moreno elmélete is. Moreno román származású kutató, viszont Ausztriában és az Egyesült Államokban dolgozott mint pszichiáter, és 1910-ben mutatta be azt a módszert, mely véleménye szerint képes feltérképezni a hálózati kapcsolatok viszonyait. Módszerében a szociometria alkalmazását javasolta és véleménye szerint e módszer használatával egyes csoportok belső szerveződése ismerhető fel, viszont használható az akciókutatásban is (Moreno, 1934:123).

Az OECD (1999:7-9.) tanulmányában a hálózati együttmüködést kapcsolatba hozzák az innovációval. DeBresson (1999) szerint nem létezhet vagy nem jöhet létre innováció ott, ahol elszigetelődés van. Egy másik fontos kritériuma a szerző szerint a hálózati innovációnak, hogy többszereplős feladat, tehát a hálózati innovációban több szektorból származó szereplőnek kell részt vennie. . Felvetődik a kérdés, hogy a magyar-román határ mentén létezik vagy nem hálózati innováció. Ha csak a meglévő problémák megoldására alkalmazott akciókutatás résztvevőit, kedvezményezetteit nézzük, akkor látható, hogy e csoportok informálisan alakultak, hiszen a civil találkozókra a helyi egyesületek, alapítványok, szövetkezetek képviselöit hívtuk meg, viszont eljöttek a polgármesterek is, sőt még egyes helyi gazdasági cégek vezetői is a találkozókra. Ez is olyan példa, amely két dolgot támaszt alá: elsősorban azt, hogy a helyi, térségi és határ menti fejlesztést nem kell ösztönözni, hiszen magas az érdeklődés, csak meg kell találni az olyan intézményi formákat, amelyek segítik a résztvevőket a fejlődési kezdeményezések megvalósításában. Másodsorban megfigyelhető, hogy a társadalmi kapcsolatok helyi szinten konjunktúrafüggőek. Ha adódik egy közös fejlődési lehetőség, akkor a helyi szereplők (önkormányzati, 
civil és magán szereplök) összefognak, és nyitottak az együttmüködésre, a fejlesztésre és az innovációra.

\subsection{Határ menti együttmüködési programok elemzése}

A disszertáció ezen alfejezetében bemutatásra kerül a PHARE CBC és az INTERREG IIIA Program. Fontos a programok elméleti bemutatása és ismertetése, hiszen ezekből finanszírozták az esettanulmányi részben elemzésre került pályázatokat. A PHARE Előcsatlakozási Alapot (Pologne-Hongrie Aid a la Reconstruction Économique) 1989-ben hozta létre az Európai Unió.

A gazdasági és politikai átmenet elősegítésére létrehozott programot 1996-ban kibővítették, és ennek köszönhetően az alapból részesülő országok száma 13-ra nőtt. Az Agenda 2000-ben az Európai Bizottság javasolta, hogy a PHARE prioritásain módosítsanak, és a jövőben a program az európai uniós csatlakozásra váró országok felkészülését támogassa.

Két fó téma jelent meg mint javasolt prioritás: az intézményépítés/intézményfejlesztés és a beruházások támogatása. Az intézményépítés fogalma abban az időszakban a demokratikus intézmények, a közigazgatási szervek és olyan új intézmények létrehozását jelentette, melyek képesek átvenni és hatályba ültetni a közösségi szabályozásokat.

A PHARE Programot elsőként 1994-ben hirdették meg az Európai Unióval közvetlenül határos országokban. Magyarországon először 1995-ben. Ausztria csatlakozását követően indult meg a PHARE Program.

Ezt követően 1996-ban a PHARE CBC az Interreg kiterjesztésével a magyarromán határszakaszon is elérhetővé vált az alap, ezáltal két nem uniós állam is pályázhatott közös projektek megvalósítására.(Héthatáron, 2004. http://www.vati.hu/files/articleUploads/5526/hu_sk_kpa_2003_final.pdf) 
A román-magyar határtérségben összesen hárommillió euró támogatás felhasználásával több, mint 110 projekt valósult meg a kisprojekt alapok keretében. A 110 projekt kedvezményezettjei a jelen kutatás célcsoportja.

A következő témákban valósultak meg pályázatok: határ menti együttmüködés a helyi gazdasági adottságok feltérképezésével és fejlesztési terveinek kidolgozásával, technológiaátadás, képzés, turizmusfejlesztés és befektetésösztönzés, IT-fejlesztés. A gazdasági együttmüködések mellett fontos szerepet kapott a belvízkár-elhárítási együttmüködés és a határvízi kapcsolatok fejlesztése, különösen a dokumentáció, a szabályzatok aktualizálása révén.

A PHARE Programnak több típusa volt:

- Több országra kiterjedő támogatás (az ún. Multi-beneficiary programs)

- Horizontális programok: Access, Catch-up Facility, SME Facility - Kis- és középvállalkozásokat támogató program, LSIF - Nagy infrastrukturális beruházások, MCTP - Több országot támogató közlekedési program, SPP

- Speciális előkészítő program a Strukturális Alapokra, Twinning stb.

- Határon átnyúló együttmüködési programok (CBC - Cross border cooperation), CREDO, INTERREG

Két fő időszak különböztethető meg a magyar-román határ menti együttműködésekben: az úgynevezett PHARE CBC és a PHARE CBC/INTERREG időszak. A PHARE CBC időszakban (1996 és 2003 között) a magyar partnerek kapták kizárólag a támogatást, viszont a projekteket közösen, a román partner bevonásával valósították meg.

A PHARE CBC/INTERREG időszak alatt (2003 és 2008 között) ugyancsak közös projektek valósultak meg, viszont a magyar partner INTERREG-et pályázott, míg a román partner PHARE CBC-t. Különböző projektekröl van szó, 
melyek megvalósításához elengedhetetlen volt a határon túli partner jelenléte, viszont a költségvetésben a határon túli partner nem szerepelt saját tételekkel, csak a tevékenységekben vett részt.

Az első időszakban a Magyarország-Románia PHARE CBC keretében a jogosult magyarországi négy határ menti megye összesen 32 millió ECU uniós forrást használhatott fel. Összesen 165 projektet támogattak, a támogatási összeg pedig megfelelt a keretösszeg 94\%-ának.

A projektek típusait vizsgálva elmondható, hogy méretük szerint három fő típust különböztethetünk meg (Lados, 2006, 204-207 oldal.).

A jelen kutatás fó elemzési pályázati típusa a „people-to-people” pályázatok, melyek a lakossági kapcsolatok fejlesztését ösztönözték, valamint a kisebb tőkeerejü szervezeteket, tehát olyan intézményeket támogattak, melyek pénzügyi és általános kapacitása alacsony (kisebb települések önkormányzata, egyesületek, alapítványok stb.). Ezek az ún. kis projektek, melyeket a „Kisprojekt Alapból” hirdettek meg.

\begin{tabular}{|c|c|c|c|c|c|c|c|c|}
\hline Év & $\mathbf{1 9 9 6}$ & $\mathbf{1 9 9 7}$ & $\mathbf{1 9 9 9}$ & $\mathbf{2 0 0 0}$ & $\mathbf{2 0 0 1}$ & $\mathbf{2 0 0 2}$ & $\mathbf{2 0 0 3}$ & Összesen \\
\hline $\begin{array}{c}\text { Kis projektek } \\
(\mathrm{db})\end{array}$ & 24 & 24 & 0 & 10 & 15 & 21 & 13 & 107 \\
\hline $\begin{array}{c}\text { Közepes } \\
\text { projektek (db) }\end{array}$ & 0 & 0 & 0 & 0 & 0 & 12 & 18 & 30 \\
\hline $\begin{array}{c}\text { Nagy projektek } \\
(\mathrm{db})\end{array}$ & 10 & 10 & 2 & 3 & 2 & 1 & 0 & 28 \\
\hline \multicolumn{2}{|c|}{ Összes támogatott projekt PHARE CBC (1996-2003) } & 165 \\
\hline
\end{tabular}

1.táblázat: PHARE CBC pályázatok száma (Lados tipizálása szerint készítve): saját számítás a VÁTI adatai alapján (http://www.vati.hu/index.php?page = main \&menu=19497\&langcode $=h u)$ 
Első időszakban 10 ezer, majd 20 ezer, míg 2000 után 50 ezer ECU volt az elnyerhető maximális összeg. 2002-től új, ágazati alapú támogatási konstrukciók (grant schemes) kerültek meghirdetésre. Ezen pályázatok keretében 70 ezer és 500 ezer euró közötti költségvetésű - Lados szerint közepes méretű pályázatokat lehetett elnyerni.

Amint a fenti táblázatban is látható, 1996 és 2003 között a kis projektek, az ún. „people-to-people” intézményi és közösségi fejlesztési projektek száma 107 volt, viszont ami érdekes lehet a kutatás szempontjából, hogy a projektek száma 1997töl csökkent. A magyarázat erre az lehet, hogy a kedvezményezettek egyre kevesebb projektet nyújtottak be, vagy a támogatási keret alacsony volt, ezáltal kevesebb pályázatot tudott támogatni a hatóság.

Az együttmüködés következő szakaszát a Magyarország-Románia, valamint a Magyarország-Szerbia és Montenegró (háromoldalú) határon átnyúló együttmüködési program 2004-2006 megvalósítása jelentette.

A program költségvetése a nemzeti társfinanszírozásokkal együtt közel 32 millió EUR Magyarországon (INTERREG) és közel 20 millió EUR Romániában (PHARE CBC).

A 2. táblázatban látható, hogy a támogatási összegek növekedtek, viszont ez annak tudható be, hogy a támogatások intenzitása is megnőtt 10 ezerről 20 ezerre, később pedig 50 ezer ECU-re. Megfigyelhető, hogy 2003-ban a támogatási keret azonos volt a 2000. és 2001. évi kerettel. A projektkérelmezők listáját tanulmányozva egyértelművé válik, hogy a támogatási keretösszegek változása csekély mértékủ volt, viszont a lehetséges pályázók száma évről évre nőtt. 


\begin{tabular}{|c|c|c|c|c|c|c|c|c|}
\hline \multicolumn{1}{|c|}{ Év } & $\mathbf{1 9 9 6}$ & $\mathbf{1 9 9 7}$ & $\mathbf{1 9 9 9}$ & $\mathbf{2 0 0 0}$ & $\mathbf{2 0 0 1}$ & $\mathbf{2 0 0 2}$ & $\mathbf{2 0 0 3}$ & Összesen \\
\hline Kis projektek & 0,19 & 0,20 & 0 & 0,46 & 0,46 & 0,87 & 0,46 & 2,64 \\
(támogatás mil. ECU) & & & & & & & & \\
\hline $\begin{array}{c}\text { Közepes projektek } \\
\text { (támogatás mil. ECU) }\end{array}$ & 0 & 0 & 0 & 0 & 0 & 2 & 4,56 & 6,56 \\
\hline $\begin{array}{c}\text { Nagy projektek } \\
\text { (támogatás mil. ECU) }\end{array}$ & 4.23 & 2,88 & 4,78 & 4,50 & 4,17 & 2,12 & 0 & 22,68 \\
\hline & & & & & & & \\
\hline
\end{tabular}

2. táblázat: PHARE CBC pályázati források (Lados tipizálása szerint készítve): saját számítás a VÁTI adatai alapján (http://www.vati.hu/index.php?page=main \&menu=19497\&langcode $=h u)$

A források felhasználásánál a két országban, Romániában és Magyarországon eltérő módszereket követtek» Magyarország: INTERREG (ERFA), Románia: PHARE CBC«. Ebből kifolyólag súlyos nehézségek és csúszások adódtak a végrehajtás során.

A magyar-román határ mentén a PHARE CBC/INTERREG IIIA Program a következő prioritásokra írt ki pályázatokat:

1. Prioritás: A határ menti térség fizikai és infrastrukturális integrációjának erösitése

1.1. A határ menti területek infrastruktúrájának fejlesztése

1.2. A környezetvédelem és árvízmegelőzés területén felmerülő közös kihívások kezelése 
2. Prioritás: A piacok integrációját elösegitó és a helyi közösségek közötti koherenciát erösitő együttmüködési kezdeményezések támogatása

2.1. Az üzleti infrastruktúra és a közös üzleti szolgáltatások fejlesztése

2.2. A vállalatok együttmüködésének támogatása

2.3. Az intézmények és a közösségek közötti együttmüködés támogatása

2.4. A kutatás- és oktatásfejlesztés és a humán erőforrás területén az együttmüködés elősegítése

A belső EU-határrégiók fejlesztését célzó Interreg program mintájára 1995-ben, Ausztria csatlakozásakor indult el a Phare CBC - Cross-Border Cooperation program Magyarországon. A program kezdetben csak az osztrák határtérséget érintette, majd fokozatosan kiterjedt a román, szlovák és szlovén határszakaszokra, végül a magyar-horvát, magyar-ukrán és magyar-szerb együttmüködésre is.

Magyar-román viszonylatban a PHARE előcsatlakozási alap támogatásával az 1996. évi programmal kezdődött a határon átnyúló együttmüködések ösztönzése, mely mindenekelőtt a térség versenyképességét hivatott javítani. E cél eléréséhez a Phare CBC Magyarország-Románia 2002 Program támogatási alapja a gazdaságfejlesztés területén nyújtott támogatást, e terület igényei és szükségletei alapján jelölve meg a támogatható tevékenységek körét.

A Phare CBC programok révén a határ menti együttmüködés területén szerzett tapasztalat, az elsajátított gyakorlat egyben belépőt jelentett az INTERREG Közösségi Kezdeményezés pályázataiban való sikeres részvételhez, a Magyarország EU-tagállammá válásával megnyíló támogatások felhasználásához. Az 1995-2003. évi Phare CBC programok összesen 135 millió euró támogatási kerettel segítették elő a kapcsolatok fejlődését és a határ menti térségek 
felzárkózását. E programok jellemzően néhány nagy értékü projektből és a kisebb léptékü fejlesztéseket ösztönző támogatási formából, az ún. kisprojekt-alapból épültek fel.

A határon átnyúló hatás vagy a határ menti együttmüködés minden esetben alapkövetelmény volt. A nagyprojektek többnyire egy-egy kiemelt - legalább kétmillió euró Phare-támogatással megvalósuló - beruházást foglaltak magukba. A kisprojekt-alapok a határon átnyúló, helyi fejlesztések támogatását szolgálták, elősegítve a határon átnyúló integrációs folyamatokat.

A 2002. és 2003. évi Phare CBC programok jellemzően a kisprojekt-alapokhoz hasonló elven működő támogatási konstrukciókat tartalmaztak, azoknál lényegesen magasabb elnyerhető maximális támogatással. Az először a 2002. évi programmal induló támogatási alapok a határon átnyúló együttmüködés egy-egy kiemelt területére koncentráltak.

A magyar-román együttmüködési programok célja a határon átívelő együttmüködés fejlesztése, intenzitásának növelése révén a határrégió versenyképességének javítása és a térség felkészítése volt az európai uniós csatlakozás kihívásaira. E célok elérése érdekében a Phare CBC MagyarországRománia 2002 Program támogatási konstrukciója a gazdaságfejlesztés területén nyújtott támogatást.

Pályázható témák voltak:

- A magyar és román határtérségek közti együttmüködés továbbfejlesztése

- A gazdasági kapcsolatok kiterjesztése a magyar és román határ menti térségekben gazdasági tevékenységet végző kis- és középvállalkozásoknak nyújtott kiemelkedő segítség révén

- A személyek és vállalkozások számára a határ mindkét oldalán nyújtott szolgáltatások elérhetőségének javítása 
- Az információáramlás és a kapcsolatok javítása magyar és román üzleti szolgáltatásokat nyújtó intézmények között

- A piaci információs és jövedelemtermelő lehetőségek javítása mind a magyar, mind a román vállalkozók számára

A határon átnyúló együttmüködéseket Magyarországon 1995 óta támogatja az Európai Unió a Phare CBC programok révén. Az 1995-2003. évi Phare CBC programok összesen 135 millió euró támogatási kerettel segítették elő a kapcsolatok fejlődését és a határ menti térségek felzárkóztatását. A belső EUhatárrégiók fejlesztését célzó INTERREG program mintájára 1995-ben, Ausztria csatlakozásakor indult el a Phare CBC program Magyarországon, mely az évek során fokozatosan kiterjedt az ország mind a hét határszakaszára.

A PHARE kisprojekt-alapok átfogó célja a kis léptékü, „emberek közötti”, határon átnyúló, helyi közösségi fejlesztések támogatása a határrégiók szereplőinek bevonásával.

Fejlesztési területei:

- Regionális fejlesztés és tervezés

- Gazdaságfejlesztés és gazdasági együttmüködés, beleértve a turizmust

- Humánerőforrás-fejlesztés

- Természet- és környezetvédelem

Az INTERREG Közösségi Kezdeményezés 1990 óta müködik. Célja elsősorban a gazdasági és társadalmi kohézió erősítése a határ menti együttmüködések támogatásával, valamint az Európai Unión belüli és kívüli tagállamok közötti együttmüködés elősegítése. 
A Közösségi Kezdeményezéseket, az egész európai térség fejlesztése és kohéziója szempontjából alapvetően fontos együttmüködési területeket támogató programokat az Európai Bizottság javasolja a tagállamoknak. Egyben meghatározza a kezdeményezések átfogó céljait és prioritásait, és az ezekhez rendelt pénzkeretet, amelyek alapján az előre definiált határ menti és makrotérségeket alkotó EU-tagállamok közös, részletes javaslatot nyújthatnak be az Európai Bizottsághoz.

A programok szabályszerü végrehajtásáért és a kezdeményezések céljainak megvalósulásáért a tagállamok által programonként felállított közös irányító hatóságok felelnek, a programok operatív menedzsmentjét - a részt vevő országokat technikai szinten képviselő - közös szakmai titkárságok látják el. Magyarországon a 2004-2006 közötti periódusban négy Interreg IIIA (VÁTI adatok, 2011) program valósult meg:

- Ausztria-Magyarország Interreg IIIA Program 2004-2006

- Magyarország-Szlovákia-Ukrajna Szomszédsági Program 2004-2006

- Magyarország-Románia és Magyarország-Szerbia és Montenegró Határon Átnyúló Együttmüködési Program 2004-2006

- Szlovénia-Magyarország-Horvátország Szomszédsági Program 20042006

A 8 ábra illusztrálja, hogy a magyar pályázók az INTERREG IIIA határ menti együttmüködési komponensre összesen 370 darab pályázatot nyújtottak be, közülük azonban csak 282 volt formailag elfogadható, ebből értékelhetőnek 173 bizonyult, vagyis felelt meg szakmailag. Tehát a beadott pályázatok felénél is kevesebb volt az olyan megfelelően előkészített pályázatok száma, amelyek támogatást kaphattak volna. 
Ez azt bizonyítja, hogy az érdeklődés a határ menti pályázatok iránt magas volt, de a pályázók felkészültsége, pályázatírói és pályázatkészítési hozzáértésük alacsony. Itt feltehető a kérdés, hogy csupán csak a pályázatírói készségek alacsonyak vagy az intézményi kapacitás kérdése a mérvadó.

Egy pályázat elkészítéséhez ugyanis nélkülözhetetlen számos tényező, például a jól felkészült munkaerő és a minőségi munkainfrastruktúra. Amint a lenti ábrán is látható, a beadott 370 pályázatból összesen 89-et támogattak a 2004-2006.közötti időszakban.

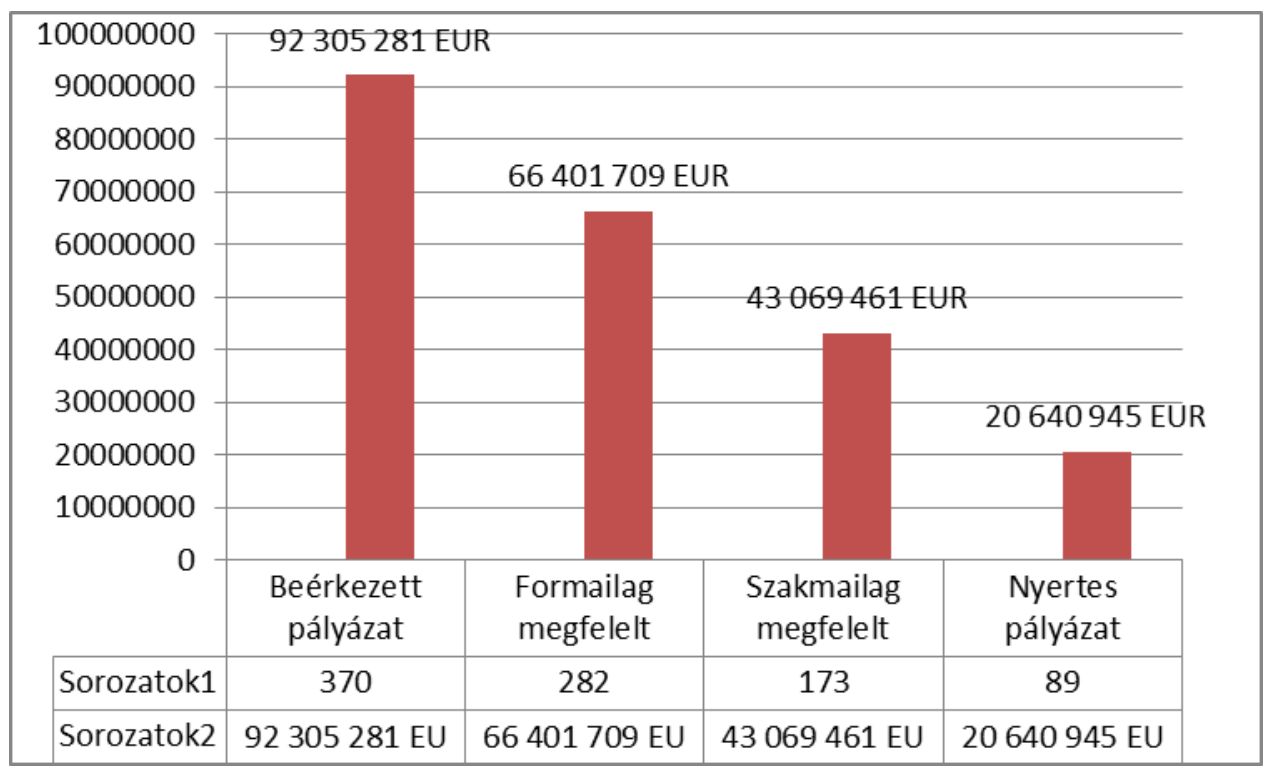

8.ábra: Magyar pályázatok száma és értéke az INTERREG IIIA 2004-2006 Román-Magyar Együttmüködési Program keretében (saját számítás a VÁTI adatai alapján)

Az INTERREG IIIA magyar pályázóit és nyertes listáit vizsgálva körvonalazódik, hogy a projektek nyerteseinek 40\%-a önkormányzati intézmény vagy önkormányzati társulás, és az is nyilvánvaló, hogy Békés és Szabolcs- 
Szatmár-Bereg megyében jelentős számban voltak a nyertes listákon civil szervezetek. Ugyanakkor a nyertes listákat az 1996-2003 közötti időszakkal összehasonlítva az is kiderül, hogy csökkent az oktatási intézmények és a különböző kamarák száma.

A nyertes pályázatok a fentiekben bemutatott prioritásokra érkeztek, számuk és a pályázati értékek is különböznek, hiszen minden támogatási prioritás intenzitása és mértéke változó volt.

\begin{tabular}{|c|c|c|c|c|}
\hline Év & $\mathbf{2 0 0 4}$ & $\mathbf{2 0 0 5}$ & $\mathbf{2 0 0 6}$ & $\begin{array}{c}\text { Összesen - típusok } \\
\text { alapján }\end{array}$ \\
\hline Kis projektek (db) & 9 & 17 & 13 & 39 \\
\hline $\begin{array}{c}\text { Közepes projektek } \\
(\mathrm{db})\end{array}$ & 5 & 6 & 8 & 19 \\
\hline $\begin{array}{c}\text { Nagy projektek (db) } \\
\begin{array}{c}\text { Évekre bontva } \\
\text { összesen }\end{array}\end{array}$ & 9 & 10 & 12 & 31 \\
\hline
\end{tabular}

3.táblázat: INTERREG IIIA magyar pályázatok száma

Lados tipizálása szerint készítve): saját számítás a VÁTI adatai alapján

( http://www.vati.hu/index.php?page = main \&menu=19497\&langcode $=h u)$

Ha összehasonlítjuk az INTERREG IIIA és a PHARE CBC nyertes pályázatait (a fenti 3. és 4. táblázat), akkor megfigyelhető, hogy a román pályázatok száma sokkal magasabb, tehát több nyertes pályázat volt a román oldalon, ezáltal feltételezhető, hogy a program támogatási keretei a PHARE CBC-ben magasabbak voltak, mint az INTERREG-ben. 
Elemezve viszont a 7. és a 8. ábra adatait egyértelmü, hogy a PHARE CBC keretében kiosztott pályázatok összértéke alacsonyabb, mint az INTERREG IIIA keretében megítélt és támogatott pályázatok összköltsége. Ez azzal magyarázható, hogy az INTERREG IIIA prioritásainak támogatási intenzitásai magasabbak voltak, mint a PHARE CBC-ben.

A 2004-2006 közötti időszakban a romániai pályázók a PHARE CBC Programból igényelhettek támogatásokat. A támogatások mértéke és intenzitása ebben az esetben is eltérő volt, viszont a pályázók a magyar INTERREG IIIA kérelmezőkkel azonos prioritásokra pályázhattak.

\begin{tabular}{|c|c|c|c|c|}
\hline Év & 2004 & 2005 & 2006 & $\begin{array}{c}\text { Összesen - típusok } \\
\text { alapján }\end{array}$ \\
\hline Kis projektek (db) & 24 & 23 & 23 & 70 \\
\hline $\begin{array}{c}\text { Közepes projektek } \\
\text { (db) }\end{array}$ & 11 & 13 & 15 & 39 \\
\hline Nagy projektek (db) & 5 & 12 & 10 & 27 \\
\hline $\begin{array}{c}\text { Évekre bontva } \\
\text { összesen }\end{array}$ & 40 & 48 & 48 & 136 \\
\hline
\end{tabular}

4. táblázat: PHARE CBC román pályázatok száma (Lados tipizálása szerint készítve): saját számítás a VÁTI adatai alapján (http://www.vati.hu/index.php?page= main \&menu=19497\&langcode $=h u$ )

Továbbá az is nyilvánvaló, hogy a jelen dolgozatban vizsgált „people to people” pályázatok főként román oldalon valósultak meg, hiszen a román kis-projektek száma majdnem duplája a magyar oldalon ugyanabban az időszakban megvalósított projekteknek. Míg a magyar oldalon 39 ilyen pályázat részesült támogatásban, addig a román oldalon 70. A kutatásban tehát összesen 109 
intézmény lehet célpont, hiszen ezen intézmények valósítottak meg pályázatot az INTERREG IIIA/PHARE CBC Programok által kiírásra került alapokból.

A lenti 9. ábrán látható, hogy a beérkezett pályázatok majdnem felét szakmailag elutasították, míg az is érdekes tény, hogy a leadott 301 pályázatból csak 214 volt formailag elfogadható. Ez valószínúleg annak tudható be, hogy a román pályázók először találkoztak az új pályázati rendszerrel és az új feltételekkel. A másik érdekesség a pályázók listáját vizsgálva, hogy számos vidéki önkormányzat, civil szervezet megtalálható a pályázatot benyújtók listáján, viszont a nyertesek közt föként városi önkormányzatok vannak.

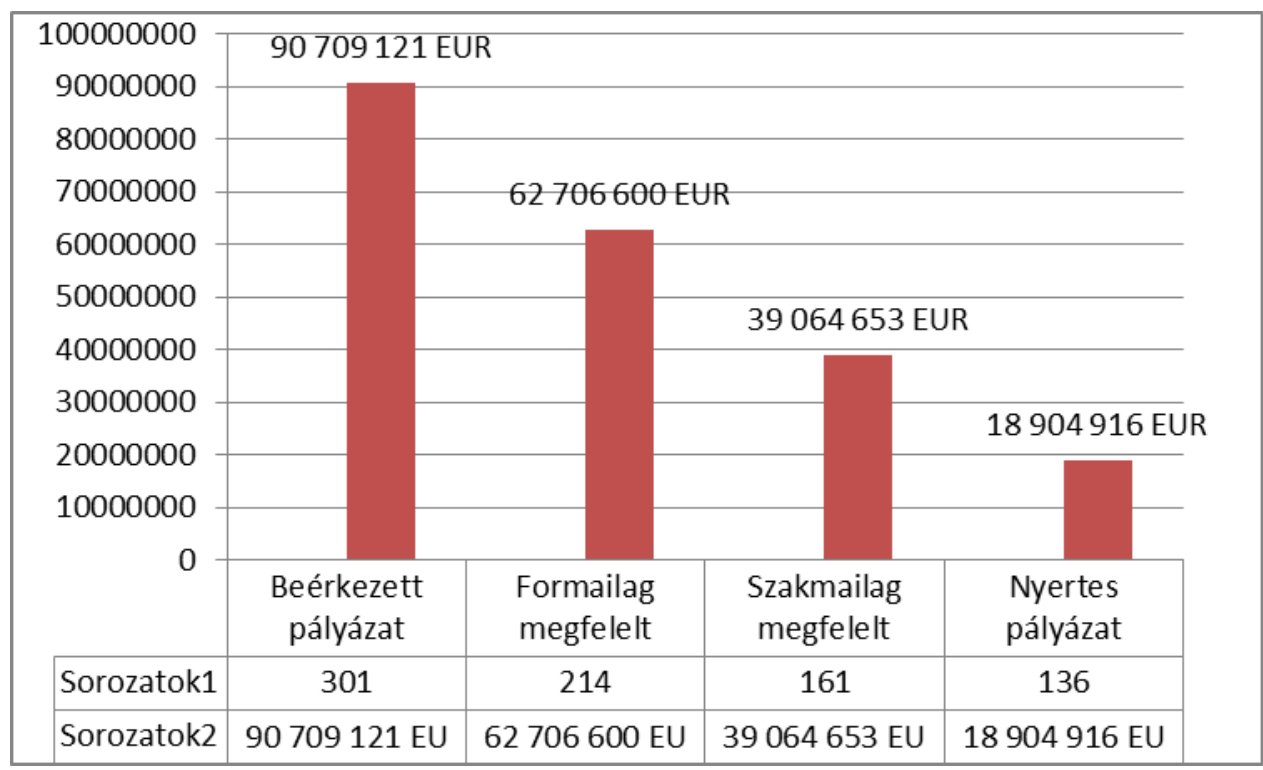

9.számú ábra: Román pályázatok száma és értéke a PHARE 2004-2006

Román-Magyar Együttmüködési Program keretében (Saját számítás a Román Integrációs Minisztérium (új nevén MDRT) adatai alapján)

Tehát a PHARE CBC 2004-2006 kírása nagy érdeklődésnek örvendett a határ mentén, viszont ezen kiírások is bebizonyították, hogy a pályázóknak sokat kell még fejlödniük annak érdekében, hogy minőségi pályázatokat tudjanak felmutatni. 


\subsection{Európai Területi Együttmúködési Program}

Az európai határon átnyúló, transznacionális, interregionális együttműködések alapvető kerete 2007-2013 között az Európai Területi Együttmüködés (ETE). Célja a határokon átnyúló együttmüködés erősítése közös helyi és regionális kezdeményezések útján, a nemzetek közötti együttmüködés megkönnyítése az integrált területi fejlődéshez vezető, a közösségi prioritásokhoz kapcsolódó intézkedések révén, valamint az interregionális együttmüködés és tapasztalatcsere előmozdítása megfelelő területi szinten.

Az ETE-programok megvalósításához jó alapot nyújthatnak a 2004-2006 között megszerzett tapasztalatok, az INTERREG Közösségi Kezdeményezési programok, a Phare CBC és egyéb, kapcsolódó Phare intézményfejlesztési programok, melyeket már az előző fejezetben bemutattunk.

A rendelkezésre álló források aránya programtípusonként:

- Határ menti együttmüködési programok: 73,86\%

- Transznacionális térség: 20,95\%

- Interregionális együttmüködés: 5,19\%

A programok lebonyolítása egységes szerkezetben történik, függetlenül az államhatárok által meghatározott területi megosztástól, közös projektek, közös döntéshozás és közös pénzügyi keretek alkalmazásával. Az ágazati és regionális programokkal szemben az ilyen együttmüködések nem önálló adminisztratív struktúrákkal, önálló jogrendszerrel rendelkezö területeken jönnek létre. Ezzel összefüggésben a programok határokon átnyúló jellemvonása alapján részben 
közös intézményrendszerrel, megállapodásokban rögzített szabályok szerint járnak el a programok irányításában és lebonyolításában részt vevő intézmények. Hat programban hárul Magyarországra az irányító hatósági szerep és az ezzel járó feladatkörök:

- Délkelet-Európai Transznacionális Együttmüködési Program

- Magyarország-Szlovákia és Magyarország-Románia mint belső Európai Területi Együttmüködési programok

- Magyarország-Horvátország és Magyarország-Szerbia mint IPA CBC programok

- Magyarország-Románia-Szlovákia-Ukrajna ENPI CBC program

Ezeken kívül Magyarország részt vesz még három ETE-programban:

- Közép-európai Transznacionális Együttmüködési Program

- Ausztria-Magyarország Területi Együttmüködési Program

- Szlovénia-Magyarország Határ Menti Együttmüködési Program

A projektek kiválasztásáról a programokat felügyelő és azok stratégiai döntéseit meghozó Közös Monitoring Bizottságok - KMB - gondoskodnak. A KMB-ben a partnerországok egyenlő arányban képviseltetik magukat.

A Területi Együttmüködési (ETE) program összköltségvetése ERDF alapból a hétéves időszakra (2007-2013) összesen 211 millió euró. Ha az összeghez adjuk a 15\%-os nemzeti társfinanszírozást, akkor a rendelkezésre álló keretösszeg 248 millió euró lesz.

Az új program tervezési folyamatában létrejött egy közös szakmai fórum, melynek célja az volt, hogy az operatív programba, majd később a pályázati 
kiírásokba, megvalósítási kézikönyvekbe olyan prioritások és feladatok kerüljenek be, melyek elősegítik a határ menti övezet harmonikus fejlődését.

A közös szakmai fórumon föként a kedvezményezett megyék (négy-négy határ menti) megyei elnökei, városok önkormányzatainak képviselöi, szektorális ügyekért felelő hatóságok, valamint állami intézmények képviselői vettek részt.

A tervezésben a civil szervezetek képviselöi alacsony számban képviseltették magukat (megjegyzendő, hogy a szakmai fórum munkáin csak meghívottak vehettek részt).

A Román-Magyar Operatív Program szerint a helyzetfelmérés és a prioritások megfogalmazása egy széles körben végzett felmérés, és a közvetlenül érintett személyek bevonásával készült a felmérés eredménye. Viszont ha elemezzük a Román-Magyar Operatív Programot, akkor látható, hogy a helyzetelemzést, a problémák felismerését kizárólag csak statisztikai adatokra alapozták. Ezáltal a programozási szakaszban nem a meglévő határ menti problémák kerültek elötérbe, hanem a közigazgatási szervezetek képviselői által felismert problémák, melyeket statisztikai adatokkal is alá tudtak támasztani.

Az új Magyar-Román Területi Együttmüködési Programnak két prioritása, nyolc beavatkozási területe és 22 intézkedése van. Bár nem történt széles körü konzultáció, elmondható, hogy az intézkedések minden szereplőnek lehetővé teszik a pályázatok benyújtását és támogatások elnyerését (kivétel a magánszektor, ahol egyes korlátozásokkal kell számolni a pályázások során).

A két prioritás az együttmüködési terület közös, fenntartható fejlesztéséhez szükséges kulcsfontosságú helyzetek javítása, valamint a társadalmi és gazdasági kohézió erősítése a határ menti térségben.

$\mathrm{Az}$ 1. prioritás tengelyre - „Az együttmüködési terület közös, fenntartható fejlesztéséhez szükséges kulcsfeltételek javítása" - a következő beavatkozási területeket hirdették meg (HU-RO Operatív Program 2007-2013): 


\subsection{Beavatkozási terület: A határon átnyúló közlekedés fejlesztése}

1.1.1. Útfejlesztés

1.1.2. Vasútfejlesztés

1.1.3. Tervek és tanulmányok készítése

\subsection{Beavatkozási terület: A határon átnyúló kommunikáció fejlesztése}

1.2.1. Szélessávú internet-infrastruktúra kiépítése

1.2.2. Közösségi kapcsolódási programok kialakítása

1.2.3. A határon átnyúló hírközlés

1.2.4. Tervek, tanulmányok készítése

\subsection{Beavatkozási terület: Környezetvédelem}

1.3.1. Természetvédelem

1.3.2. Vízgazdálkodás

1.3.3. Hulladékgazdálkodás

1.3.4. Tervek, tanulmányok készítése

A 2. prioritási tengelyre - „A társadalmi és gazdasági kohézió erősítése a határ menti térségben" - a következő beavatkozási területeket hirdették meg (HU-RO Operatív Program 2007-2013).

\subsection{Beavatkozási terület: Határon átnyúló üzleti együttmüködés támogatása}

2.1.1. Üzleti infrastruktúra fejlesztése

2.1.2. Üzleti együttmüködés támogatása

2.1.3. Turizmusfejlesztés 


\subsection{Beavatkozási terület: Együttmúködés ösztönzése a kutatásfejlesztés $(K+F)$ és innováció területén}

2.2.1. Közös kutatási infrastruktúra fejlesztése

2.2.2. Közös kutatási projektek

2.2.3. A K+F tevékenységekben érintett szektorok közti együttmüködés segítése 2.2.4 Tanulmányok, tervek kidolgozása

\subsection{Beavatkozási terület: Együttmüködés a munkaerö-piacon, oktatásban - készségek, ismeretek közös fejlesztése}

2.3.1. Oktatási intézmények közötti együttmüködés

2.3.2. Munkaerőpiac-együttmüködés

\subsection{Beavatkozási terület: Egészségügy és közös veszélyelhárítás}

2.4.1. Közös egészségügy, kockázatkezelési infrastruktúra fejlesztése

2.4.2. Közös intézményfejlesztés, koordináció és képzés

\subsection{Beavatkozási terület: Közösségek közötti együttmúködés}

\subsubsection{Közösségek közötti együttmüködés}

Ha összevetjük a PHARE CBC, INTERREG IIIA és az új Európai Területi Együttmüködési Programok beavatkozási területeit, akkor megfigyelhető, hogy számos különbség van a „régi”, 2007 előtt meghirdetett pályázatok között, és az új, 2007-2013 közötti időszakra tervezettek között. Ami viszont a jelenlegi kutatás szempontjából jelentős, hogy az új programkiírási periódusban is 
megtalálhatóak az ún. „people-to-people” pályázatok a 2.5. „Közösségek közötti együttmüködés" elnevezéssel.

A PHARE CBC/INTERREG IIIA pályázati rendszerhez képest az új programkiírási időszak egyik újdonsága, hogy a román-magyar határ mentén kétféle pályázati modell felhasználásával lehet támogatást elnyerni.

Az egyik az ún. egylépcsős pályázati eljárás, melyben a teljesen kidolgozott pályázatot kell benyújtani, melyet egy elöre meghatározott kritériumrendszer alapján kell elkészíteni és ugyanazon kritériumok alapján bírálják el, később pedig a Közös Irányító Hatóság hozza meg a döntést a pályázatok támogatásáról.

A másik modell a kétlépcsős pályázati rendszer, mely főként nagyobb volumenű fejlesztések támogatását célozza. Ennek lényege, hogy az első szakaszban csak a projektötletet, a koncepciót kell benyújtani.

Ha a projektkoncepciót elfogadja a Hatóság, akkor az ún. rövid listára kerül, és egy következő szakaszban kell a pályázatot teljes mértékben kidolgozni és benyújtani. (http://huro-cbc.eu/hu/palyazasi_modellek)

Az új időszak abban is különbözik a régitől, hogy a pályázatokat kizárólag közösen lehet benyújtani, tehát minden partnernek van saját pénzügyi felelőssége és vállalása, ugyanakkor a pályázatokat csak angol nyelven lehet benyújtani.

A megvalósítás is teljes mértékben angol nyelven történik, tehát az időközi elszámolásokat, jelentéseket, amiket a Hatósághoz kell benyújtani, kizárólag angol nyelven kell elkészíteni.

Az Európai Területi Együttmüködési Program utolsó kiírása 2012. január 24-én zárult le, viszont mivel még a beadott projektek számát, értékét, a nyertesek listáit nem hirdették meg, csak az ezen időszak elött meghirdetett pályázatok eredményeit tudjuk bemutatni a lenti táblázatokban. 


\begin{tabular}{|c|c|c|c|c|}
\hline Év & $\mathbf{2 0 0 8}$ & $\mathbf{2 0 0 9}$ & $\mathbf{2 0 1 0}$ & $\begin{array}{c}\text { Összesen - típusok } \\
\text { alapján }\end{array}$ \\
\hline Kis projektek (db) & 26 & 0 & 22 & 48 \\
\hline $\begin{array}{c}\text { Közepes projektek } \\
(\mathrm{db})\end{array}$ & 58 & 12 & 89 & 159 \\
\hline $\begin{array}{c}\text { Nagy projektek (db) } \\
\text { Évekre bontva } \\
\text { összesen }\end{array}$ & 0 & 36 & 0 & 36 \\
\hline
\end{tabular}

5.táblázat: Az ETE román-magyar közös pályázatok száma

(Lados tipizálása szerint készítve): saját számítás a Joint Technical

Secretariat adatai alapján (http://huro-cbc.eu/en/financed_projects)

$\mathrm{Az}$ 1. prioritást elemezve mindhárom évben látható, hogy a pályázók száma sokkal alacsonyabb, mint a 2. prioritás keretében, sőt számos projekt esetében nem is voltak nyertes pályázatok. Ennek egyik lehetséges oka az, hogy egyes beavatkozási területek tényleges, valós problémákra összpontosítottak, viszont az 1. prioritás bizonyos beavatkozási területei nem keltették fel a kedvezményezettek figyelmét és nem tekintették valós kihívásnak, következésképpen nem pályáztak.

Két beavatkozási területen is alacsony volt az érdeklődés a pályázatok iránt, mint például az 1.2.1. beavatkozási területen („Szélessávú internet-infrastruktúra kiépítése”), valamint az 1.1.2. beavatkozási területen („Vasútfejlesztés”).

$\mathrm{Az}$ internetfejlesztésben egyik partner sem volt érdekelt, ugyanis a határ menti településeken két irányzat a jellemző: többnyire magánkézben lévő szolgáltatók uralják az internet-szolgáltatás piacát és monopolhelyzetükből adódóan a felhasználók nagy részét (beleértve az önkormányzatokat is) maguk köré tömörítették. A kis községekben, ahol valóban szükség volna internet- 
szolgáltatásra, az önkormányzatok még alapproblémák megoldásával küszködnek (víz-, csatorna-, úthálózat kiépítése stb.).

Egy másik fontos tényező az volt, hogy magáncégek nem pályázhattak e programokban, és az önkormányzatok vagy civil szervezetek nem vállalták fel egy ilyen szolgáltatás kialakítását, ami öt évig kötelezettséget jelentett volna a beruházás müködtetésére. Tehát az eddigi három pályázati kírásban összesen egy pályázatot támogattak a „Szélessávú internet-infrastruktúra kiépítése” beavatkozás keretében.

Az 1.1.2. „Vasútfejlesztés” egy másik érdekes tervezettámogatási beavatkozás volt, mivel a román-magyar határ mentén egyáltalán nem voltak olyan kedvezményezettek, akik a program által megszabott feltételeknek megfelelve pályázhattak volna. Az Operatív Program ugyanis elöírta, hogy a pályázó székhelyének a program területén kell elhelyezkedni, vagy megengedte, hogy helyi kirendeltségek pályázhassanak. Viszont sem a román CFR, sem a magyar MÁV-START Zrt. nem felelt meg a pályázati feltételeknek, így az ilyen jellegü fejlesztések elmaradtak.

Következésképpen az erre a beavatkozási területre tervezett összegeket átcsoportosították más területekre, és 2011-re írták ki azokat.

A PHARE CBC/INTERREG IIIA és az ETE Programok táblázatait összevetve megfigyelhető, hogy a támogatott projektek száma a strukturális új területi alapból sokkal magasabb, mint a 2007 előtti időszakban. Tehát az új program jóval több pályázónak tette lehetővé a támogatás-igénylést. Ami az ETE táblázathoz (4.számú táblázat) füzhető, hogy 2009-ben nem kerültek kiírásra soft, „people-to people” projektek, ezért a táblázatban 0-1-gyel jelöltük a pályázatok számát.

Az új program másik sajátossága, hogy a finanszírozás a strukturális alapoknak megfelelően zajlik, tehát utófinanszírozás jellemzi. Ez azt jelenti, hogy a nyerteseknek magas pénzügyi kapacitással kell rendelkezniük annak érdekében, 
hogy képesek legyenek hatályba léptetni a pályázatokat. A támogató tehát nem nyújt előleget, azaz nincs előfinanszírozás, hanem a pályázó saját költségvetéséből, saját jövedelméből valósítja meg a pályázatban vállaltakat, és az elszámolásokat követően igényelheti vissza a kiadásait.

A támogatás intenzitása is megváltozott. A PHARE CBC/INTERREG IIIA Programokban az általános eljárás az volt, hogy $10 \%$ volt az önerö, amit a szervezetnek saját hozzájárulásként be kellett foglalnia a pályázatba. Jelenleg az új ETE Programban az önerő 2\% és 5\% között van a román intézményeknek (függ az intézmény jogi státuszától, és 5\% jár a magyar partnereknek).

\subsection{A partnerség vizsgálata a határ menti térségben}

Az elöző fejezetekben bemutatásra kerültek a határ menti programok. A pályázatok egyik kötelező feltétele, hogy minden kérelmezőnek legyen határon túli partnere. A pályázat beadásának feltétele a határon túli aktív partnerség. A 2007-2013-as programozási időszakban nem csak a partnerség volt kötelező, hanem a közös megvalósítás és a közös költségvetés készítés, valamint a közös felelősségvállalás is kötelező feltételekké váltak, ezzel erősítvén a partnerség elvének fontosságát is.

A partnerség vizsgálatát nem csak a megvalósított pályázatok elemzésével végeztük a szükebb kutatási térben, hanem egy kérdőív segítségével is, mely alapja a 4. fejezetben létrehozandó indikátornak. Az indikátor elkészítéséhez egy komplex kérdőívet hoztunk létre, viszont jelen alfejezetben csak egy részét hasznosítjuk az eredményeknek.

A kutatás második kutatási kérdése (H2), hogy a közintézmények, civilek befolyásolják vagy sem a társadalmi kapcsolatháló kialakitását, és hogy a pályázatokban „mesterségesen” vagy természetesen alakultak-e ki a 
kapcsolatok, valamint hogy ezen kapcsolatok „konjunktúrafüggők”-e és csupán a pályázati források elnyerésére jöttek-e létre, vagy hosszú távú partnerségek alakultak ki? (H2) A kutatási kérdés célja tehát, hogy megvizsgálja a partnerség és a pályázatok minőségét úgy, hogy közben bemutatja a támogatási forrásokat is 2004-től egészen napjainkig.

A kérdés tehát az, hogy a megalakított partnerségek „konjunktúrafüggő"k”-e és csupán a pályázati források elnyerésére jöttek-e létre, vagy hosszú távú partnerségeket alapoztak meg. Ennek az ellenőrzésére a kérdőívből kapott információkat vettük alapul, viszont megvizsgáltuk a beadott pályázatokat is 2006-tól egész napjainkig. Ezt a hipotézist csak részben sikerült igazolni, hiszen a kérdőív eredményeiből az derült ki, hogy vannak együttmüködések, viszont kevés az a szervezet, amely PHARE CBC/INTERREG IIIA programban közösen pályázott és jelenleg is együtt pályázik. Ami jellegzetes, hogy a nagyobb városok és civil szervezetek folytatták az együttmüködést a régi partnerrel. A nagy városok azok, amelyek új pályázatot nyújtottak be közösen, a civil szervezetek egy része pedig új partnerrel nyújtott be pályázatot, más szervezetek pedig nem pályáztak közösen.

A kisvárosok és kisebb civil szervezetek egy része már nem pályázott az új Területi Együttmüködési Programban, mindösszesen 7 kisebb szervezetet találtunk a támogatott listákon a 109 szervezet közül, aki PHARE CBC/INTERREG IIIA támogatást kapott. Ennek a fő oka véleményem szerint az, hogy az új szabályozás - strukturális alap lévén - megköveteli, hogy a szervezet stabil pénzügyi helyzettel rendelkezzen, hiszen csak ez tudja igazolni, hogy képes lesz előfinanszírozni a pályázatát. Ami viszont jellemző számos szervezetre, hogy nem „people-to-people” pályázatot adtak be a 2004-2006 időszakban, a 20072013 pályázati rendszerben pedig új prioritásra nyújtották be pályázatukat.

Véleményem szerint ez pozitív dolog, hiszen a PHARE CBC lényege az volt, hogy a csatlakozásra váró országok határrégióiban intézményfejlesztést és 
kapacitásnövelést idézzen elő. Tehát a nagyvárosok és a nagyobb civil szervezetek a „people to people” pályázat keretein belül szerzett tapasztalatok után nagyobb léptékủ pályázatokat valósítottak meg az új programból. Ez annak is köszönhetö, hogy az új programban sokkal több prioritás van, mint a PHARE CBC/INTERREG IIIA kiírásaiban.

Elemezve a PHARE CBC, INTERREG IIIA és az ETE Programok nyerteseit elmondható, hogy a kedvezményezettek többsége csupán egy-egy pályázatot valósított meg, tehát esetükben a határon túli partnerrel való kapcsolat nem bizonyult tartósnak. Elképzelhető, hogy a pályázati feltételrendszer volt az, amely az ilyen jellegü partnerségeket összehozza. Egymásra épülö, hosszú távú partnerkapcsolatokat kialakító projekteket általában a megyei intézmények, városi közigazgatások és hatóságok valósítottak meg.

Úgy vélem, hogy több rendezvényt kellene szervezni, amelyekre egy adott stratégia alapján lehetne mozgósítani a potenciális partnereket. Tehát nem olyan partnerkereső találkozókat kellene szervezni, amelyekről minden érdeklődőt értesítenek, hanem olyan rendezvényeket, amelyekre a szervezeteket például típusaik vagy érdekeltségi körük alapján hívják meg. Egy másik feladata az Irányító Hatóságnak és a területi irodáknak az volna, hogy a már lezárult pályázatokat monitorizálja, ellenőrizze, továbbá ösztönözze és segítse a partnereket, hogy folytassák a közösen elkezdett fejlesztéseket.

Továbbá a kiértékelési kritériumrendszerbe be kellene építeni olyan pontszámot is, amely előnyben részesítené az olyan pályázókat, akik kézzelfogható eredményekkel tudják igazolni, hogy egy közös fejlesztés folytatása az adott projekt, mely egy lezárt pályázat folytatása, vagy esetleg más forrásból elkezdett tender. Ezáltal az egész pályázati rendszernek lenne egy folyamata, viszont ezt a kritériumot jól meg kellene fogalmazni és ezáltal biztosítani, hogy valóban olyan pályázók kapják meg a pluszpontokat, akik teljesítik a kritériumot. 
A partnerség elvét nem csak papíron és iratokkal kellene igazolni, hanem konkrét tevékenységekkel, közös programokkal, közös tapasztalatokkal. Jó példák a müködő partnerségre a részvételi kutatásban létrehozott Civil Klaszter és az Európa-kapu Európai Területi Társulás, hiszen ez a két intézmény úgy jött létre, hogy magyar és román civil és önkormányzati szervezetek alapították olyan időszakban, amikor elöreláthatólag körülbelül két évig nem lesznek pályázati kiírások.

A partnerek több találkozót szerveztek, ám ezzel párhuzamosan számos intézmény lemorzsolódott, így a két fentebb említett intézmény létrehozásában már csak azok a civil és önkormányzati intézmények maradtak meg alapítóként, akik teljes elszántsággal és odaadással vesznek részt jelenleg is az együttmüködésben.

A kutatási kérdésünk nem bizonyosodott be teljesen, viszont az adatelemzések és a kérdőívek eredményei arra mutatnak rá, hogy az idő múlásával sokkal több az állandó partnerség. Az viszont kérdéses, hogy konjunktúrafüggők-e vagy nem ezek a partnerségek, hiszen olyan partnerségekröl van szó, melyek keretében a partnerek számos közös tevékenységet és programot tudtak megvalósítani, és e tevékenységekre jelentős forrásokat is kaptak. A kérdés, amire igazán nehéz megtalálni a választ, hogy csak azért van együttmüködés a szervezetek között, mert erre az Európai Unió támogatást nyújt, vagy akkor is együttmüködnének, ha erre nem léteznének források.

Az interjúk készítésekor kiderült, hogy a PHARE CBC Román-Magyar 20042006 alapból támogatást nyert civil szervezetek (alapítványok, egyesületek) mindösszesen 12\%-a nyert támogatást a 2007-2013-as Strukturális Alapból az Európai Területi Együttmüködési Program keretében. Arra a kérdésre, hogy miért nem folytatták az elkezdett közös tevékenységeket, a megkérdezett szervezetek többsége úgy nyilatkozott, hogy ennek fő oka a forráshiány. Próbáltunk arra is 
választ kapni, hogy miért nem lettek elkészítve közös pályázatok az új Területi Együttmüködési Program keretén belül, hiszen feltételeztük, ha a civil szervezetek a PHARE CBC pályázatokban már együttmüködtek, akkor valószínüleg a Strukturális Alapok keretében is folytatják a közös szakmai munkát. A megkérdezett civil szervezetek 69\%-a viszont elmondta, hogy az együttmüködést nem tudták előfinanszírozni ${ }^{9}$.

Az együttmüködés a civil szervezetek között tehát a pénzügyi erőforrások hiánya miatt nem folytatódott. Ha ezt az eredményt vesszük alapul, akkor elmondható, hogy a civil szervezetek közötti együttmüködést nagymértékben befolyásolja a meglévő támogatások mértéke. Ha a közigazgatások közötti együttmüködést elemezzük, akkor látható, hogy a nagyvárosok, megyei tanácsok és más önkormányzatok sokkal jellegzetesebben tudtak megjelenni az Európai Területi Együttmüködési Programban.

Az interjúkból egy érdekes dolog derült ki: a kis önkormányzatok, vidéki települések képviselői ismerik az Együttmüködési Programot, viszont nincs határon túli partnerük, nem mertek kezdeményezni, nem érezték magukat képesnek részt venni egy határon túli programban. A támogatott szervezetek képviselőitől viszont megtudtuk az interjúkból, hogy a közös együttmüködés számos eredményt hozott a közösségekbe, viszont a megvalósítás és a menedzsment nehézkes volt.

Arra a kérdésre, hogy ha a támogatási források csökkennek-e vagy nem lesznek elérhetőek, miből tarthatóak fenn a lezárt pályázatok eredményei, az önkormányzatok képviselői válaszukban elmondták, hogy a költségvetésből nehézkesen tudnak elkülöníteni forrásokat. Tehát ez a tény is alátámasztja azt a kijelentést, hogy a partnerségek nagyban függnek a támogatási forrásoktól.

\footnotetext{
${ }^{9}$ Az új ETE Programokban, melyek része az ERFA-nak (Európai Regionális Fejlesztési Alap), a kedvezményezettek elő kellett finanszírozzák a pályázatokat, a visszafizetések átlagos időtartama 6-10 hónap volt. Tehát nem csak jelentős likviditási kapacitásra volt szükség, hanem a visszatérítés is hosszú időtartamú volt.
} 


\section{Fejezet: HATÁR MENTI PÁLYÁZATOK, INTÉZMÉNYEK ÉS TÁRSADALMI TŐKE}

A kutatás negyedik fejezetében az akciókutatás módszerével, kérdőív és interjú segítségével a társadalmi tőkét elősegítő pályázatok eredményességét vizsgáljuk, azt próbáljuk felmérni, hogy a már lezárt pályázatok mennyire voltak eredményesek. Egy kérdőív segítségével szeretnénk létrehozni egy saját módszertant, mely a pályázatok eredményét méri a pályázatokat, azok lezárása után. Szóval ebben a fejezetben kidolgozom a saját módszertanomat, mely a pályázatok eredményességét méri egy átfogó kérdőív segítségével. Egy másik cél, hogy a negyedik fejezetben bemutatásra kerüljenek azon intézmények, amelyek képesek olyan integrált pályázatok megvalósítására, melyek nem csak a terület fejlesztését segítik elő, hanem a társadalmi tőkét és a civil szerveződést is támogatják.

A harmadik kutatási kérdésünk (H3), hogy a megfelelő tőke (itt főként Európai Uniós forrásokra gondolunk) használata, a támogatások elköltése a térségben elősegítheti-e vagy nem a határ menti fejlődést, képes-e vagy nem valós és fenntartható eredményeket biztosítani. Ennek vizsgálatára meg kell nézni, hogy a megvalósított határon átnyúló fejlesztések eredményei hogyan lettek fenntartva.

Egy másik eleme a vizsgált kérdésnek, hogy van-e megfelelő szándék és pályázati "kedv", tehát megtalálhatóak-e a térségben az olyan intézmények, amelyek képesek felvállalni az akciókutatás eredményeként javasolt pályázati ötleteket, fejlesztéseket.

Feltétezzük (H3), hogy a 2004-2006 időszakban a megvalósult, sikeresnek mondott pályázatok fokozzák az érdeklödést, és hogy a 2007-2013 idöszakban megvalósult pályázatok száma nőtt, ső́t egy időben a pályázatok számának emelkedésével növekedett a versengés, és ennek következtében a pályázatok minősége is. Ezen kijelentés arra mutat rá, hogy a térségben számos olyan 
intézmény van, mely képes lesz a 2014-2020-as programozási idöszakban megvalósitani olyan integrált, határon átnyúló pályázatokat, melyek a térség fejlödését segítik elö.

A fenti kutatási kérdés megválaszolására több szakaszban kerül sor: elsősorban a kérdőív segítségével a szük kutatási térben kiértékelésre kerülnek a 2004-2006 időszakban beadott és megvalósított pályázatok. Ezáltal egy általános képet kapunk a 2004-2006 közötti pályázatok eredményességéről.

A kutatási kérdés második részének a megválaszolására, mégpedig, hogy a szük kutatási térben (a két magyar és két román megyében) van-e megfelelö intézmény, mely integrált pályázatokat lesz képes megvalósítani az elkövetkező pénzügyi programozási időszakban, a következő módon vizsgáljuk meg: a teljes határ menti pályázatokból megnézzük, hogy milyen arányban és milyen intézmények voltak támogatva a 2007-2013-as időszakban a szűk kutatási térben.

A meglévő intézményekkel felvesszük a kapcsolatot és egy közös munkatalálkozót szervezünk, ahol a jövőbeli pályázati ötleteikről és elképzeléseikről beszélünk majd velük. Így lesz egy átfogó képünk arról, hogy melyek azok az intézmények, amelyek képesek és van szándékuk a térség fejlesztésére. 


\subsection{Az intézményi kapacitás és a fejlesztés kapcsolata}

A harmadik kutatási kérdés elméleti alapjai a kapacitás, az intézmények képessége, hogy egyes fejlesztéseket, törekvéseket megvalósítsanak. Annak érdekében, hogy megtaláljuk a választ arra, hogy melyik a megfelelő intézményi forma, mely a határ menti együttmüködést a legjobban elősegíti, fontos bemutatni az intézményi kapacitás elemeit, valamint megnézni, hogy mit is rejt magában az a fogalom, hogy intézményi fejlődés, kapacitás.

Az utóbbi években irányzatok jelentek meg a közszféra müködésével kapcsolatban. Ezen irányzatok közös fő jellemvonásaként kiemelkedik a fejlesztés és a hatékonyság. A közszférának állandó kihívást jelent a kérdés, hogyan lehetne jobban dolgozni, ugyanakkor célkitüzésként a növekedés, fejlődés és a szegénység csökkentése szerepel.

A kívülállók gyakran korlátozott ismeretekkel rendelkeznek arról, hogy mi történik a szervezet belsejében. Egyszerüen felismerhetök viszont a gyenge teljesítmények, amikor ennek okai és eredményei egymást erősítik, és a közszolgálat által nyújtott szolgáltatásokban nyilvánulnak meg.

A kapacitás felbecsülésére szolgálnak a változó eljárások és az egymáshoz kötődő döntések inputjai: stratégiai és operacionális választások minden szinten. A gyenge kapacitás eredményeként kevesebb pénzügyi forrást használnak fel, nagyobb az igény a kapacitásfejlesztésre és ez által nehezebben fogalmazódnak meg a fejlesztési döntések,, és ha megfogalmazódna, akkor a kérdés az, hogy hogyan fejlesztünk és kik a fejlesztési partnerek, melyek az igények, mi jellemzi a folyamatokat, mennyi összeget fordítsunk fektessünk fejlesztésre.

$\mathrm{Az}$ intézményfejlesztés fogalma különböző módon jelenik meg a szakirodalomban. Peter Morgan szerint az intézményfejlesztés meghatározó elemei a szervezeti egységek és csoportok képessége, melyen keresztül felismerik és megoldják az intézményi és szervezeti fejlesztés mindenkori problémáit 
(Morgan, 1997:14-39). Az elmélet egyik gyenge pontja a morgani megközelítésben az, hogy az intézményfejlesztés kizárólag magában foglalhatja a közszektor-fejlesztés koordinált és összefüggő tevékenységeit foglalja magában. Azokat pedig közösen valósíthatja meg egyrészröl a közszektor, másrészről a civil és magánszféra bevonásával, vagyis mindenképpen figyelembe kell venni a fenntartható fejlődést képező elemeket. Morgan elméletének egy másik hiányos része, hogy csak az egyének és csoportok kapacitására fekteti a hangsúlyt, az intézményi tényezőket teljes mértékben figyelmen kívül hagyta.

A capacity building másik meghatározása egy rendszerelméleti megközelítés, melyet a Közigazgatási Szótár fogalmaz meg a következőképpen: bármilyen rendszerbeli vagy folyamati kezdeményezés, melynek célja a választott vezetők, menedzserek, köztisztviselők és általában a közszférában dolgozók képességeinek és hatékonyságának erősítése (Shafritz 1986:79-80). Ez tipikus közigazgatási megközelítés, hiszen a capacity building olyan tényező, mely mind a civil, mind a magánszektorban megtalálható.

Nehézséget jelent, hogy nincs egy nemzetközi szinten elfogadott meghatározás a kapacitásfejlesztésre. Különböző társadalomtudományi ágak, mint a politikatudomány, gazdaságtan, szociológia, az intézményekkel foglalkozó tudományok, pszichológia vagy neveléstan változó szempontokat hangsúlyoznak, viszont vannak közös pontok is, melyekben a meghatározások megegyeznek.

A kapacitások fejlesztése a nemzetek felelőssége, de egyre inkább elmondható, hogy ez globális felelősséggé alakul át és a tudománypolitika kiemelkedő kihívásai közé tartozik. Ugyanakkor az emberi és intézményi kapacitás fejlesztését megfelelő nemzetpolitikával is kell irányítani, melyhez az országos fejlesztési célokba épített releváns és hatékony stratégiák, valamint akciótervek kapcsolódnak.

Magyarországon és Romániában a '90-es években a demokratikus normák érvényesítése érdekében nagymértékủ változások történtek. A kilencvenes évek 
első felében a demokratikusnak mondott intézményi „építés” (angolul: „institution building”) volt meghatározó. Közpolitikai problémákra az állami szervezetek új intézményi keretek megteremtésével válaszoltak és a policy jellegü megoldásokat az újonnan megszervezett intézményektöl várták. 2000 elején erőteljes, új szervezeti struktúra megjelenése tette bonyolultabbá a már meglévő állami szervezeti struktúrák müködését.

Ezen új szervezetek szükségszerúen lettek megalakítva, mivel az Európai Unió kötelező kritériumként szabta meg egyes nemzeti és regionális ügynökségek létrehozását. Egy másik fontos mozzanata az intézményfejlesztésnek Romániában és Magyarországon a vissza nem térítendő alapok felhasználása következtében alakult ki.

Ágh Attila (2008:7-33) szerint Magyarországon az eredményes állam (effective state) és a jó kormányzás (good governance) fogalomrendszere is marginális maradt, mivel a magyar társadalomtudományi köznyelv - nyilván a közgazdaságtan hatására - többnyire csak a hatékonyság fogalmát használja, ami megengedhetetlen leegyszerüsítés.

A közpolitika fogalomrendszerében az intézményi teljesítmény és a társadalmi kapacitás megítélésében három fogalom játszik szerepet, az eredményesség (effectiveness), a hatékonyság (efficiency) és a hatásosság (efficacy). Az első, az eredményesség bináris jellegü, miszerint az adott cél vagy teljesült, vagy nem. Ez a politikus világa, akit az érdekel, hogy megvalósult-e, amit ígért, amiről döntött. A másik, a hatékonyság, a folyamat eredményének és a felhasznált erőforrásoknak a viszonyát fejezi ki, mint költség-haszon elemzés, százalékban is mérhető, növelhető és csökkenthető, ez a szakértők alkalmazásának terepe. A harmadik, a hatásosság a társadalomban - és annak érintett rétegeiben - való hatást vizsgálja, hiszen az eredményes, sőt hatékony akció is számos kedvező és kedvezőtlen társadalmi hatással járhat. 
Az adminisztratív kapacitásnak Ágh A. szerint a következő mozzanatai vannak:

(1) a közigazgatási szolgáltatások színvonala („management”)

(2) az ügyfelek (állampolgárok és intézmények) méltányos, partnerként való kezelése (,fair” magatartás)

3) a pénzügyi tervezés és az eszközök hatékony felhasználása („,budgeting”).

Romániában a good governance kifejezést a társadalomtudományi köznyelv egyszerü fordításként vette át: ,jó kormányzás” (románul buna guvernare). Megfigyelhetö, hogy éppen a civil szervezetek eröltetik e fogalom bevezetését. 2000 elején erőteljesebb lett a fogalom használata a "Good governance in Romania”, alcímủ: „Partnerség egy jó kormányzásra” megjelentetésével (Asociaţia Pro Democraţia Egyesület, a teljes tanulmány elérhető a következő URL címen:http://www.apd.ro/files/publicatii/Buna guvernare la romanighid de bune practici.pdf).

A társadalom fejlődésével és az intézményi rendszerek, a törvényhozás változásaival különböző és jellegzetes változások következtek be a kormányzás fogalmaiban is, melyek a kapacitás nehézségeit is érintik. Kooiman és Kjaer szerint kétféle szint létezik: vertikális-hierarchikus kormányzás és horizontálispartnerség jellegü kormányzás (Kooiman, 2003; és Kjaer, 2004).

$\mathrm{Az}$ államszervezetnek és államigazgatásnak van egy felső „koncentrált” kormányzati, miniszteriális, hatalmi-politikai és egy alsó, relatíve autonóm, „dekoncentrált" közpolitikai-szakmai (országos hatáskörü szervezetek, quango) szintje. A szervezett társadalomnak is van egy felső, centralizált tetőszintje és egy alsóbb, decentralizált alapszintje.

A civil társadalom tetőszintjét nevezzük társadalmi középnek, mezopolitikának vagy mezokormányzatnak, míg az alsóbb szintjét mikropolitikának, vagy a civil társadalom önkéntes szervezetei (voluntary association) mikrokormányzatának, s 
mindkettőnek megvan az államigazgatásban is a megfelelő szintje, partnere. A kapacitásfejlesztés több jellemzőt foglal magában: tudományos, szervezetiintézményi és humánerőforrás tartalma is van.

A kapacitásfejlesztés fő célja az Agenda 21-37. fejezete szerint (UNCED-1992), hogy a környezeti tényezők függvényében erősítse az eljárásokat és a hatályba ültetési folyamatokat.

1991-ben az ENSZ Fejlesztési Programja (UNDP) egy tanácskozást szervezett Delft városában (Hollandia) „Stratégia az ivóvízszektorban” címmel. A küldöttek a 19 ESA fejlődő országból érkeztek és a kapacitásnak, mint fogalomnak a következö három célkitüzését határozták meg:

1. egységes politikai konszenzussal és vezetéssel egy harmonikus környezet kialakítása;

2. az intézményfejlesztésnek magában kell foglalnia a közösségi részvételt is;

3. a vezetési szinteket és a humán erőforrást erősíteni kell.

Tovább folytatva az ESA-meghatározást elmondható, hogy a kapacitásfejlesztés több mint egy képzés, amely magában foglalja a következőket: szervezeti fejlesztést, humánerőforrás-fejlesztést és az intézményi, jogszabályi fejlesztést. A sikeres humán és intézményi fejlesztésnek a kapacitásfejlesztés a kiindulópontja, és ez az alap elengedhetetlen ahhoz, hogy egy intézmény minden egyes célkitüzését elérje. Eredményes humánerőforrás-fejlesztést, valamint jobb munkateljesítményt eredményezhet, ha a kapacitásfejlesztési kezdeményezéseket ösztönzik, ami sokoldalú fejlesztést eredményezhet. »Global Development Research Center (GDRC), (http://www.gdrc.org/uem/capacity-define.html)《 


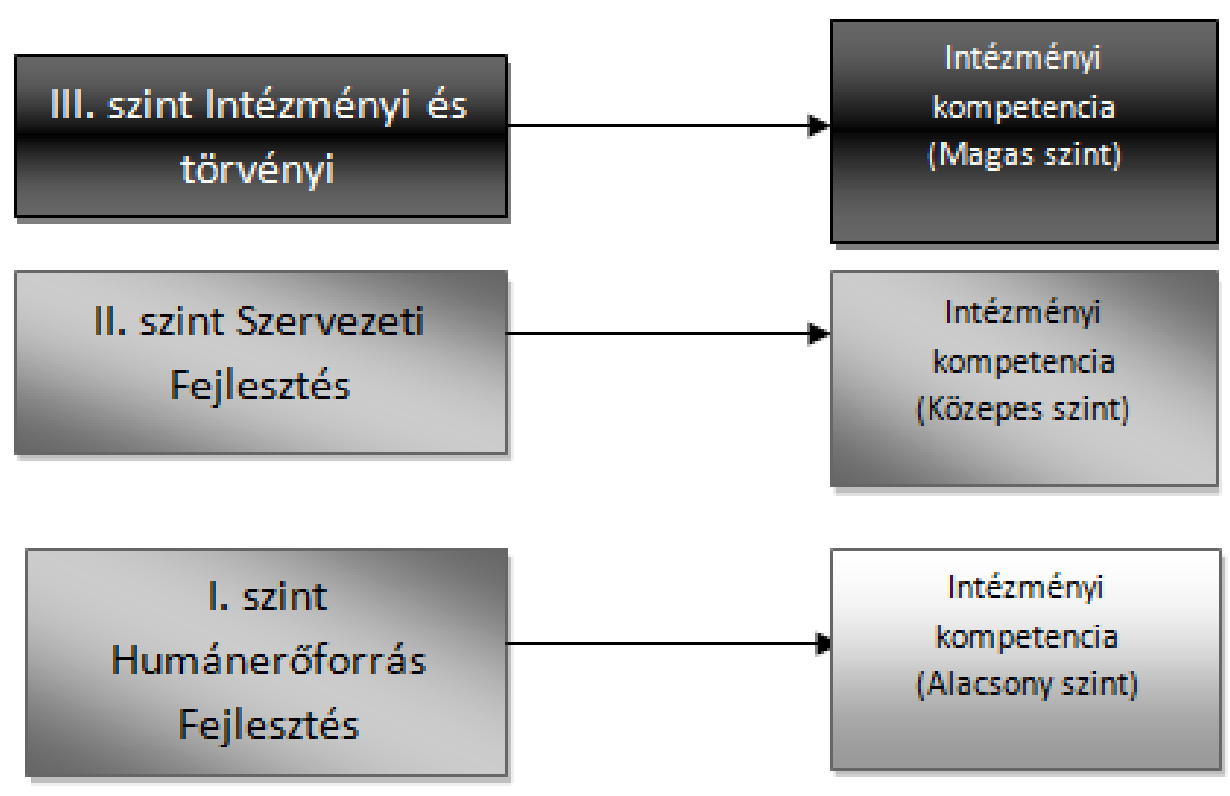

\section{0. ábra: A kapacitás fogalma az ESA Delft meghatározása alapján (saját szerkesztés)}

A GDRC úgy tekint a kapacitás kérdésére, mint egy folyamatra, mely magában foglalja a hozzáadott oktatási értékeket, a kiképzők felkészítését, multiplikátor hatású tevékenységeket és hálózatépítést. Mindez az intézményi kapacitásfejlesztés, valamint a humán kapacitásfejlesztés része.

A GDRC-ben 15 program segítségével fejlesztették kapacitásaikat. A következő ábrában láthatóak azon kérdések, amelyeket a kapacitásfejlesztés során fontos megvalósítani a GDRC szerint:

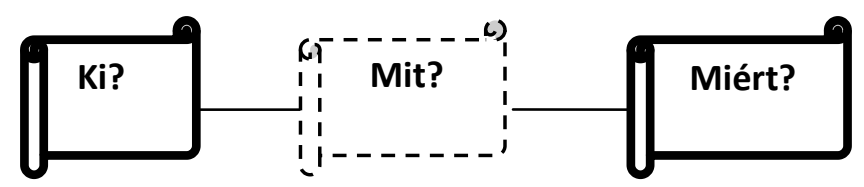

11. ábra: saját szerkesztés a GDRC programjainak elemzése alapján 
A 10. és a 11. ábrát összehasonlítva elmondhatjuk, hogy mind az UNDP, mind a GDRC azonos jellemzőkkel illeti a kapacitásfejlesztést. A GDRC a kapacitásfejlesztés meghatározása érdekében három kérdésre keres választ:

A. KI? - ugyanis a fejlesztésben részt vehetnek egyének, közösségek, magánszféra képviselői, nonprofit szervezetek és kormányzati intézmények;

B. MIT? - az információ elérhetőségének elősegítése és ezen ismeretek hatályba ültetése;

C. MIÉRT? - elősegíti vagy nem a fenntartható fejlődést.

A humánerőforrás-fejlesztés az egyének felkészülésének ismeretében zajlik, célja a szakértelem és információnyújtás, mely képzések és továbbképzések révén valósulhat meg, és eredményeként elősegíti a résztvevőket a tényleges munkában. Jelen tevékenységeket intézményi szinten végzik, ezek vagy small level beavatkozások, amelyek nem igénylik a vezetőség jelenlétét.

Miután a szervezeti fejlesztés egész intézményre kiterjedő tevékenység, melynek célja erősíteni a belső és külső szervezeti struktúrát és kapcsolatokat. Ezen a szinten fontos szerepet játszik a külső kapcsolatok erősítése és partnerségi menedzsment folytatása minden meglévő szférában (köz, magán és nonprofit).

Sokszor a vezetőségi szint beavatkozása nélkül ez a tevékenység nem végezhető el, így a beavatkozás második fajtája middle level beavatkozásnak nevezhető.

$\mathrm{Az}$ utolsó és legmagasabb beavatkozási szint, amint azt az ábra is illusztrálja, a high level, mely intézményi és törvényi kezdeményezéseket jelent. Vagyis a tevékenységben az intézmény minden szintje részt vesz, azonban a törvénymódosítások, melyek a kapacitásfejlesztéshez szükségesek, külső cselekvést is igényelnek. 
A kapacitás „kliensei”, kedvezményezettjei változóak. Nincsenek kész megoldások és bármely programnak, javaslatnak, megoldásnak meg kell felelnie a helyi és intézményi sajátosságoknak. Kapacitásfejlesztés a helyi közigazgatásokban, közösségekben és nonprofit szervezetekben valósulhat meg, azonban a kormányok szintjén és a magánszférában is szükség lehet kapacitásfejlesztésre.

Az Európai Unió által 2005 szeptemberében kiadott Institutional Assessment and Capacity Development címú tanulmányban a Capacity Development olyan folyamatként van leírva, mely révén a személyek és intézmények kialakítják és fejlesztik tudásukat. Intézményen kívülálló, strukturális és intézményi tényezők befolyásolhatják az intézmény- és humánerőforrás-fejlesztést.

A strukturális tényezők hatással vannak az egyének és a rövid távú döntések kivitelezésére. A következő tényezők a legfontosabbak:

- Az állam történelmi alakulása, a megbízható források, az állami legitimitás, és kapcsolat a gazdasági struktúrák és az intézményi szintek között.

- Természeti és humán erőforrások, társadalmi és etnikai struktúrák, demográfiai változások, regionális hatások, Globalizáció, geopolitika, nemzetközi kereskedelem és befektetési rendszerek, migráció, urbanizáció stb.

Egy állam, melynek gyenge a legitimitása, nem várhatja el, hogy a lakosság higgyen az ígéreteknek, például olyan szlogeneknek, miszerint a kifizetett adóknak fontos szerepük van a jó közszolgáltatások nyújtásában. Gyakorta az intézmények kifejezést a szervezet szó szinonimájaként használják, mégis ebben 
az összefüggésben rugalmas társadalmi struktúrákról beszélünk, melyek törvényes normák szerint alakultak ki.

Az intézmények lehetnek hivatalosak és nem hivatalosak, az Európai Unió angol kifejezésével: formal és informal. Legfontosabb intézményi tényezők:

- Törvényes normák, előírások a hatalom és autoritás gyakorlására, a családtól az állami szintig, magában foglalva a gender tényezőket is a hatalommegosztásban.

- Társadalmilag beágyazódott normák, melyeket a kormányzati szervek érvényesítenek., és a közmenedzsment végrehajtásának mikéntje (how we do things here?).

- A meglévő helyzet és a burjánzó közszféra hordozói, akik lehetnek idősek, tanárok, doktorok, lelkészek, miniszterek vagy elnökök.

- Irányító normák a változásokra, például el kell felejteni a kölcsönös szívességek és ajándékok kifejezéseket.

- Irányító normák arra, hogyan legyen minden törvényes a nemzeti általános törvények gyakorlásában és a törvényhozási folyamatokban, valamint ezek használata az informális szabályzatok evolúciójában.

Az intézményi kapacitással kapcsolatban megjelentek a keretrendszerek, melyek az Új Intézményesítést (New Institutionalism), egy nagyon széles körü és elterjedt intézményi vizsgálatként értelmezik (Hall \& Taylor, 1996:948-951). Az intézményeket ezen elmélet szerint úgy határozták meg, mint elöírások szerint müködő szervezeteket, mely előírásokat a szervezet tagjai általánosan elfogadják. A ,játékszabályok” (rules of the game) (North, 1990:3-5) lehetnek informálisak (normák, szokások, eljárások) vagy formálisak (törvények, szabályozások, standardok stb.).

Az intézmények befolyással vannak a csere tranzakciós költségeire, azaz csökkenhetik a mérés, a megállapodás és a kikényszerítés költségeit, növelhetik a 
tőke mobilitást, csökkenthetik az információs költségeket és lehetővé teszik a kockázatkezelést, azaz meghatározzák, hogy mely cseréket lesz érdemes végrehajtani, és melyeket nem.

Magyarország és Románia az Európai Unióhoz való csatlakozás előtt és azt követően is elöszeretettel használta az „intézményfejlesztés” és a „kapacitás” szavakat a közintézmények müködésében. Mi e folyamatok lényege?

2000 elejétől Magyarországon az állami szerepvállalás nyomán a folyamatos technikai fejlődés, a gazdasági növekedés üteme magas szintü állami szolgáltatásokat eredményezett. Az Európai Unió elöírásainak betartása annak érdekében, hogy a csatlakozás zökkenőmentes legyen központi és helyi szinten is, gyors, néha túlzottan felgyorsított modernizációra kényszerítette az állami szektort.

Romániában ez a folyamat a 2002-2003-as időszakban kezdődött, és a csatlakozás előtti és utáni években erőteljesebbé vált. Ebben az időszakban mind Romániában, mind Magyarországon két, egymásnak ellentmondó folyamat figyelhető meg: az állami közszolgáltatások minősége javult, mert a társadalom ezt igényelte, másodsorban a gazdasági változásokra is reagálni kellett.

A kapacitásfejlesztés hosszú távú és rendkívül forrásigényes vállalkozás, ezért önmagában egyetlen országtól sem szabad komoly és egyben folyamatos fejlesztéseket várni. A valós kapacitásfejlesztéshez világméretü tudományostechnológiai kapacitásfejlesztésre, a nemzetközi tudományos közösségnek az illető társadalom valamennyi szektorával történő partneri együttmüködésére van szükség. A dolgozat keretében azt vizsgáljuk, hogy a határ menti intézmények közösen, határon átnyúló jelleggel, kezdeményeztek-e ilyen jellegü kapacitásfejlesztést.

Ha a kapacitásról és intézményfejlesztésről beszélünk, említést érdemel egy másik fontos tényező is, mellyel a román és magyar közigazgatási intézmények egyazon időben küszködtek, mégpedig az adminisztratív reform. Az 
adminisztratív reform két nagy szakasza a „New Public Management” és a „Performance Management-Market testing”, melyeket pár mondatban az alábbiakban vázolunk.

A New Public Management magát az adminisztrációt támadta azt állítva, hogy az alapprobléma a közadminisztráció alacsonyabb hatékonysága, ezért privatizálni kell, azaz a magánszektor nagy nemzetközi gyakorlatát kell átvenni. Az NPM tágabb értelemben a modern jóléti állam általános - a fenti tényezőkkel összefüggő, de azokon túlmutató - válságtüneteire és problémáira adott reakcióként is értelmezhető. E megközelítésben az NPM-et (Inglehar, 1990:3041) mint a jóléti állammá fejlődött nemzetállam hármas legitimitási, kölcsönös függési, illetve az igények és a gazdasági lehetőségek egyensúlybomlása által eredményezett, a gazdaság túlterhelésével kapcsolatos válságra adott modernizációs válaszként is felfoghatjuk.

Az NPM globális megítélésnek egyik - ha nem „a” - döntő kritériuma mindenképpen az, hogy milyen mértékben képes a kormányzás rendszerének problémáit megoldani, illetve az annak javításával kapcsolatos ígéreteket beváltani.

A „Performance Management-Market testing” az adminisztráció kompetenciájának kiterjesztését, az ügynökségek nagyobb hatáskörrel való felruházását, az önállósságot célozza meg (Merkel W., 2004:33-58).

A nemzetközi adminisztráció gyors európaizálódásának három fő tényezője van:

1. Az intézmények konvergenciája - autonóm és instrumentális intézményi modernizáció és európaizáció.

2. A közpolitika-csinálás - három alapvető módszer a szakpolitikák egyeztetésére: harmonizálás, koordináció és integráció.

3. Az adminisztratív elitek konvergenciája - engrenage - összeszokás. 
Az államnak, mint intézményrendszernek a mérete fontos, hiszen az államban adott belső törekvés a hivatali apparátus túlburjánzásához vezethet, mely túlterhelést és gyenge államot eredményez. A gyenge államnak nincs határozott politikai stratégiája és a döntések megvalósítására erős politikai akarata. A nyugati közszférában a legnagyobb változás a kilencvenes években történt, amikor a kormányzatról a kormányzásra váltottak.

Az administrative capacity véleményünk szerint az, hogy mennyire képes az állam a növekvő komplexitású társadalom irányítását ellátni, és feltevődik a kérdés, hogy a PHARE-program milyen mértékben volt hatásos, növelte-e vagy sem az administrative capacityt.

A fenti elméleteket összegezve a kapacitás dimenziói a következők: a meglévő intézményrendszer irányítása és koordinálása (management), a funkciók állandó terjeszkedésének lebonyolítása és összehangolása (adaptability), és az egész rendszer megújulására való készség (institutional design).

A „public reform” kérdése Romániában és Magyarországon is jelentkezik. A 2000-es évek elején az állami kapacitás hiányosságokat mutatott: az állami kapacitás féloldalasan - mint csupán adminisztratív kapacitás - jelent meg, mely a megkövetelt változások végrehajtásában mutatkozott meg a nemzetközi szervezetek és az EU felé, viszont megjelenik a politikai kapacitás - politikai elit kérdése és szerepe is -, vagyis a politikai vezetés dimenziója (political leadership). A politikai elit tervezőképességének, kezdeményező-készségének és ellenőrző szerepének nagy jelentősége van a változások végrehajtásában, a politikai intézményrendszer kiépítésében és az állami (politikai és adminisztratív) kapacitás összekapcsolódásában a társadalmi kapacitással. Következésképpen elmondható, hogy az eurokapacitás az állami és társadalmi kapacitásból eggyüttesen eredeztethetö. 
Az EU-kapacitás három folyamatra szükíthető le (Barbara Nunberg, 2000:171196):

1. Civil service human resource management - politikailag semleges, professzionális adminisztráció kialakítása továbbképzéssel, az érdemek alapján való előléptetésekkel, és az emberi erőforrásokkal való hatékony gazdálkodás.

2. Policy formulation and coordination capacity - a központi kormányzat centrumának képessége az európai uniós politikák koordinálására mind intézményi, mind pedig szakmai/személyi oldalról.

3. EU accession management - európai uniós csatlakozás - egyrészt megfelelő intézmények létrehozásával, másrészt az összes intézmény Eprofiljának kialakításával és azok koordinálásával, valamint a megfelelő szakmai, személyi kapacitások kialakításával.

Mind Romániában, mind Magyarországon a központi közigazgatási szervek fő célja az volt, hogy professzionális adminisztrációt alakítsanak ki, mely képes legyen az európai uniós szabályozások átvételére és hatályba ültetésére. Ezzel párhuzamosan mindkét országban létrejöttek az európai uniós csatlakozás által szükségessé vált új intézmények. Elmondható tehát, hogy Nunberg integrációs elméletének részletei megtalálhatóak az állami központi szereplők kezdeményezéseiben.

Egy másik irányzat, mely szorosan kapcsolódik a közigazgatási kapacitás kérdéséhez, a teljes intézményrendszer megújulása oly módon, hogy a politika és az adminisztráció teljes mértékben szétválik. Ez olyan kihívás, amellyel nem csak Magyarország és Románia szembesült, azonban a megoldás még várat magára. Kérdéses, hogy az európai uniós kapacitás egyenlö-e a politics és policy új viszonyával, és az is, hogy ha tovább boncolgatjuk ezt a témát, beszélhetünk-e az 
állami kapacitásról, mely a társadalmi kapacitást veszi figyelembe a döntések meghozatalánál.

A civil kapacitás müködésének elemzése előtt röviden ismertetjük a civil társadalom jelentését és kialakulását. Elsőként Arisztotelész írt a civil társadalomról, latinul societas civilis, ógörög megfelelöje politike koinona, ami civil társadalmat jelent. Viszont az Arisztotelész-féle civil társadalom nem napjaink civil társadalmával megegyező fogalmat takart, hiszen a politike koinona kifejezés voltaképpen a politikai társadalom müködésére utal, melyben az állampolgárok résztvevői a politikának, tehát az állam és a társadalom fogalma nem különül el élesen. Ezt a gondolatmenetet megtalálhatjuk a Politika címü művében is: „Minthogy minden városállamban egy bizonyos fajta közösséget ismerhetünk fel, s minden közösség nyilván valami közjó megvalósítására alakult, világos, hogy noha mindezek valami jó elérésére törekednek, a legfőbb jó elérésére elsősorban mégis a legfelsőbbrendű közösség törekszik, amely a többit magában foglalja. Ez pedig az, amit városállamnak nevezünk, vagyis az állami közösség." (Arisztotelész 1984:71).

A középkorban változás történt, hiszen az egyén érdekei helyett a közösségi érdeket helyezték erőteljesebben elötérbe, viszont a keresztény elméletekben a dolgok természetes rendje megismerhetetlen, az etika és a vallás nem különül el (Arato - Cohen 1992: 84-86).

A vallási szokások és hagyományok mind Magyarországon mind Moldovában, Havasalföldön és Erdélyben különbözőek. Ezen hagyományok, szokások kiterjednek és befolyásolják a civil jellegü tevékenységek fejlődését. Míg a magyar lakta területeken a katolikus egyház támogatta a hívőket, hogy adakozzanak és segítsék a szegényeket, mert úgy vélték, ez a valós hívő hozzáállás, addig a román lakta területeken a vallási vezetők azt próbálták elhitetni a hívekkel, hogy ha adakoznak, örök életet nyernek. Szóval e területeken az adományok kifejezetten templomok építését és díszítését szolgálták, a cél 
pedig egyszerủen csak az volt, hogy elnyerjék az örök életet. Ezeken a területeken hiányzott a filantrópia, mint fogalom, az adományozás és adakozás a közösségnek vagy a közösség olyan tagjainak, akik erre rászorulnak, teljesen ismeretlen volt.

A XV. században az ortodox egyház lett a legnagyobb földterületek tulajdonosa Moldovában és Havasalföldön is. Lévén, hogy az egyház tág autonómiával rendelkezett, ezt a hatalmát főkent a főnemesek és a klerikális képviselők érdekében használta - e két kedvezményezett csoport kezelte az egyház vagyonát -, és soha nem a szegény, de hívő földmüvesek megsegítésére. Az egyház fontos pénzügyi kedvezményeket élvezett, például nem kellett adót fizetnie.

Egyesek szerint a civil társadalom fogalmának eredete a protestáns etikában lelhető fel. Max Weber szociológiai vizsgálatai a protestáns etika és a kapitalizmus kapcsolatára mutatnak rá. Eszerint a reformáció új értékeket hoz a társadalmi normák és a keresztényi hit világába (Weber M, 1982:279-287).

John Locke, a felvilágosodás egyik markáns képviselője a „A két értekezés a kormányról” (1986:126-141) címü munkájában bemutatja a társadalmi szerveződés gondolatát. Ezen időszakban megfogalmazták a civil társadalom klasszikus elméletét az állam és társadalom teljes mértékű szétválasztásával. A klasszikus civil társadalomról ír Adam Ferguson is, és Adam Smith folytatja ezt a gondolatmenetet és a morális individuumnak (egyénnek) a társadalomban betöltött szervező erejéről értekezik.

Kant gondolkodásában szétválik a jog nyilvános szférája és az erkölcs magánszférája, ugyanakkor nála megjelenik a politikai társadalomként értelmezett állam elválasztása a polgári társadalomtól. 
Pavluska Valéria öt jellemzővel írja le a civil társadalom klasszikus fogalmát (Pavluska 2006:28-29.):

a) az egyén: olyan személy, mely függetlenül cselekszik és morálisan viselkedik;

b) az egyetemes ész: mint a társadalmi rend alapja;

c) az erkölcsi érzés: az erkölcs transzcendentális jellege;

d) a közösség: az értékekben osztozó személyek összessége;

e) az önkéntes társulás: az erkölcsi érzületen, együttérzésen alapuló kölcsönösség.

Alexis de Tocqueville" Az amerikai demokrácia" címü munkájában fogalmazza meg a demokratikus társadalom sajátosságait. Előtérbe helyezi az amerikai demokrácia értékeit, a társadalmi egyenlőséget, az önkormányzatiságot és decentralizációt, másrészt rámutat arra, hogy a demokrácia magában hordozza a tömegek és a közvélemény uralmának, valamint a túlzott egoizmusnak a veszélyét.

A XIX. század közepétől kevésbé használatos a civil társadalom meghatározás, majd Antonio Gramsci, az Olasz Kommunista Párt filozófus-fötitkára az, aki az 1920-as években visszahozta a civil társadalom fogalmát. Szerinte a civil társadalom a kulturális intézmények összessége, nemcsak gazdasági, hanem a társadalmi érintkezés színtere, és mint ilyen, a forradalmi harc átmeneti stratégiai eszköze (Anheier-Glasius-Kaldor 2004:32-33, Bartal 2005:20-21).

Ralf Dahrendorf szerint a modern közösségek fö eleme egy müködő civil társadalom, mely felismerhető a következő kijelentésből is: „Az embereknek kötődésre és választási lehetőségekre van szükségük ahhoz, hogy lehetőségeiket a maguk teljességében élvezhessék /.../ Ezek a kötődések az autonóm társulások 
variációit igénylik, amit civil társadalomnak nevezünk." (Dahrendorf 1997, idézi Vercseg 2004:12).

Jenei György professzor rávilágított, miszerint a román-magyar határ mentén is érzékelhető, hogy a civil társadalom kialakulása a társadalmi csoportok belső motivációján alapszik. A civil társadalom kialakulása ugyanis csak belülről vezérelt lehet. Az állam szerepe fontos; jogi és intézményi kereteket kell biztosítania, amelyek nem korlátozzák a társadalmi csoportok kezdeményezéseit a különböző intézmények alapítására és müködtetésére. Csak az a civil társadalom fejlődőképes, amely proaktív, feltételeket igénylő és kezdeményező. Ha ez a belső motiváció hiányzik, ha nincs egy autonóm ethosz, akkor nem fejlődik ki civil társadalom sem (Jenei Gy., Kuti Éva, 2007:129-169).

A román-magyar határ mentén az együttmüködések első szakaszában fontos szerepe volt a „civil jellegü” partnerségeknek, hiszen a partnerségek többségét különböző csoportok kezdeményezték. Példaként említhetünk ifjúsági találkozókat, egyházi kórusokat, nőszövetségeket, kézmüves egyesületeket.

Feltehető a kérdés, hogy mi a különbség a civil és közigazgatási kapacitás között. A capacity building szó eredetét vizsgálva elmondható, hogy már a magyarra fordítása is számos kérdést vet fel. Az Európai Unió hivatalos szótárának magyar megfelelője a kapacitásfejlesztés, kapacitásképzés, kapacitáskiépítés, és a következő meghatározás kapcsolódik a fogalomhoz: szervezeti és technikai képességek, valamint az erőforrások építése és fejlesztése egy adott szervezeten belül.

(http://glossary.eea.eu.int/EEAGlossary/C/capacity_building)

A fogalom meghatározásában figyelembe kell venni a magyar fordítás három fó jellemzőjét: épités, fejlesztés, képzés. Ez a három szó abban a kontextusban, ahogyan az Európai Unió szótárában jelenik meg, lényeges eltérést mutat. Meg kell húzni a vonalat a capacity development és a capacity building között. A különbség a két fogalom között jelentős: a capacity development a meglévö 
kapacitásokat fejleszti és építi ki, míg a capacity building a nem létező kapacitásokat fejleszti ki az egyes intézményekben.

Az ENSZ Fejlesztési Programja (UNDP, www.undp.org) által megfogalmazott definíció szerint a kapacitásépítés átfogó folyamat, mely magában foglalja az akadályok felismerésének lehetőségét, és a fejlesztéseket ennek megfelelően tervezi és menedzseli. Felismeri a reális humán erőforrásokat, intézményeket és a támogató politikai környezetet.

Az ENSZ által leírt kritériumokat elemezve az intézményfejlesztést olyan folyamatként definiálhatjuk, melyben a személyek, intézmények, csoportok, szervezetek egyénileg vagy közösen fejlesztik képességeiket annak érdekében, hogy különböző feladatokat lássanak el, problémákat oldjanak meg, célokat tüzzenek ki és valósítsanak meg.

E gondolatsor mentén haladva, a kapacitásépítés három szintjét különböztetjük meg: helyi, közigazgatási és globális. Helyi szinten a kapacitásfejlesztés célja a közösségi fejlődés, tehát az összes meglévő erőforrás teljes mértékü bevetése annak érdekében, hogy a közösség fejlödjön.

Ebben a környezetben fontos szerepe van nem csak a helyi állami szerveknek (önkormányzatok, hatóságok), hanem a civil szervezeteknek is. A közös érdek a közösségi-társadalmi feladatok minél hatékonyabb ellátása. Viszont meg kell említenünk egy fontos tényezőt, éspedig a közigazgatási fejlődés és a közösségi fejlödés kapcsolatát. Beszélhetünk-e arról, hogy egy időben fejlödik a közigazgatás és a közösség? Van-e kapcsolat e két fogalom között?

A közigazgatási és a helyi fejlődés fontos szereplöje a civil szféra, melynek szerepe az utóbbi időben kirobbant pénzügyi válság hatására jelentősen megnőtt. A participatív/közremüködő közigazgatás képes bevonni minden intézményt a fejlödésbe, ugyanakkor kihasználja a civil szférával való együttmüködésben rejlő lehetőségeket. Egyes közösségi szolgáltatások ellátására a közigazgatásnak sem pénzügyi, sem humán erőforrásai nem elegendőek, így általában a 
leghatékonyabb megoldás a civil szervezetek bevonása egyes közfeladatok ellátásába.

A civil szervezetek szerepe a közösség és az önkormányzatok méretével arányosan nő. Ott, ahol az önkormányzati apparátus kicsi, egyre nehezebb megfelelni a társadalmi elvárásoknak valamint a lakosság által igényelt minden szükségletet kielégíteni. Egy másik tényező, mely a civil szervezetek beavatkozásának szükségességét alátámasztja a közösségi-társadalmi feladatok ellátásában, a szakértelem.

Bizonyos szakterületeken, témákban, feladatkörökben az önkormányzatok nem rendelkeznek megfelelő/elegendő szakképzettséggel rendelkező személyzettel, vagy ha mégis, időhiány miatt nem minden esetben tudják a társadalom részéröl elvárt igényeket kielégíteni. Egy további tényező, mely a civil szervezetek beavatkozását szükségszerüvé teszi, a szociális és más jellegü problémák megoldása.

Összefoglalva, a kapacitásfejlesztés fő közpolitikai szereplői helyi szinten a civil szervezetek és az önkormányzatok. Megjelennek persze más közpolitikai szereplők, résztvevők is, viszont a kapacitásfejlesztés szempontjából ezúttal a fentebb felsoroltak a lényegesek.

Románia és Magyarország esetében, mint sok más európai uniós tagállamban, ez a kapacitásfejlesztés összefolyik az európai uniós kapacitással. A kapacitás tehát leszükíthető arra a kérdésre, hogy az adott állami intézmény rendelkezik-e azokkal a képességekkel, amelyeket az európai uniós tagság megkövetel.

A kérdés az, hogy az intézmények képesek-e különbözö támogatások, források megszerzésére, lehívására és hatályba ültetésére úgy, ahogyan azt az Európai Unió elöírja. Elmondható, hogy a csatlakozás nem egyenlő a teljes integrációval, 
hiszen jelenleg mind Magyarország, mind Románia tagja az Európai Uniónak, de vitatható és elemezhető az EU-s kapacitásuk szintje.

Ha egy összehasonlítást végzünk például a magyar és román, vagy francia és német rendszerek finanszírozási politikája között, netalántán a civil szféra bevonását követjük a közfeladatok ellátásában, világossá válik az előző kijelentés értelme. E két állam csatlakozott ugyan az Európai Unióhoz, viszont az intézményi kapacitásaik mind állami, mind regionális, helyi szinten nem versenyképesek a régi EU-s tagállamokéval.

A WSF Konferencia fö célkitüzése a kapacitásfejlesztés nemzetközi értelmezése volt. A globális megközelítés nem egyetlen civil vagy szervezeti, intézményi képesség fejlesztését tartja fontosnak, hanem azok összességét vizsgálja. Ha e kijelentés szerint határozzuk meg a kapacitásfejlesztést, megállapítható, hogy az akadémiai világ széles köre részt vehet ebben az aktusban.

A fenti információkat összegezve elmondható, hogy a kapacitásfejlesztés és annak három szintje, valamint a fejlesztések céljai nem feltétlenül jelentenek újdonságot, eltérést az eddigi legjobb gyakorlatoktól.

A harmadik szint a kapacitásfejlesztés globális értelmezése. Itt a fő kérdés, ami felmerül az, hogy az országok vagy globális régiók képesek-e megoldást találni egyes nehézségekre, mint például a szegénység vagy a gazdasági elmaradottság, ugyanakkor e gondok felszámolása során hogyan lehet ésszerủen használni a kapacitásfejlesztést. Az sem mellékes, hogy sikerülhet-e minden egyes adottságot, forrást közösen egy rendellenesség megoldására fókuszálni. 


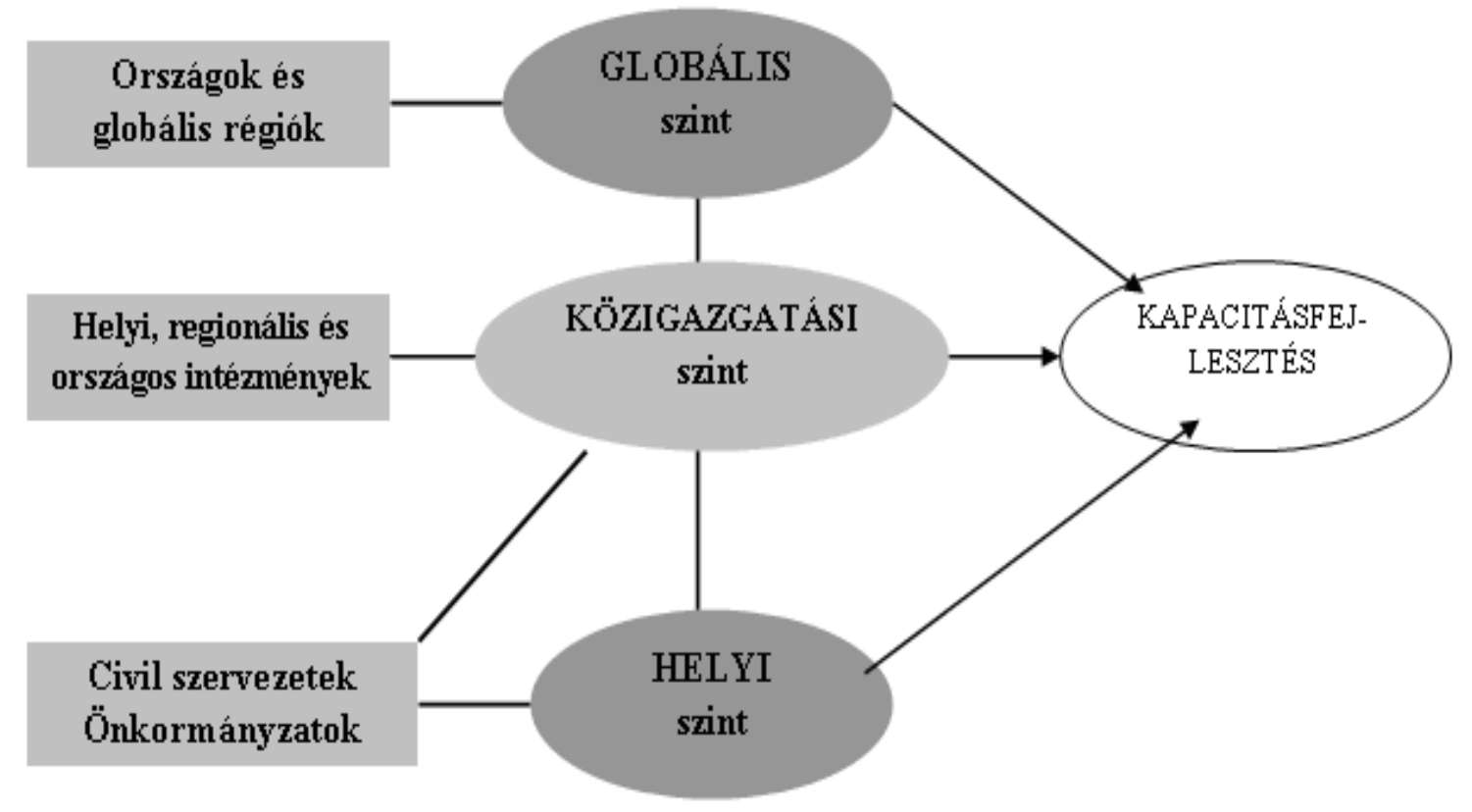

12. ábra: saját szerkesztés az ENSZ és a WSF kapacitásfejlesztési szintjei alapján

A megközelítés újszerűsége, hogy a kapacitásfejlesztés a fejlődést stratégiaként értelmezi. Ami fontos e megközelítésben, hogy a kapacitásfejlesztés nem egy stagnáló, passzív folyamat.

Amint a fenti 12. ábra mutatja, a civil szervezetek nem csak helyi szinten, hanem a regionális és országos, úgynevezett közigazgatási szinten is szerepet játszanak. Elemzésünkben szeretnénk rávilágítani, hogy a civil szervezetek kapacitásfejlesztése nem csak a saját szervezeti kapacitásra vonatkozik, hanem számos esetben beszélhetünk az általunk megalkotott „participatív közösségi civilek" új fogalmáról is. A részt vevő/aktív civil szervezetek azon csoportosulások, amelyek formálisan vagy informálisan együttmüködnek a közigazgatással, és olyan tevékenységeket, feladatokat látnak el, amelyeket teljesen vagy részlegesen átvettek a közigazgatási szervektől. Továbbá részt vevő/aktív közösségi civil szervezetnek nevezzük az olyan nonprofit egyesületet 
is, mely olyan programokat, tevékenységeket valósít meg, amelyek az adott pillanatig nem voltak elérhetőek a lakosság számára.

A partneri viszony kifejlesztésének alapvető követelményei (Jenei, Kuti,19 old. ) a következők:

1. A politikai intézményrendszer továbbfejlesztése olyan megújulás legyen, amely a gazdasági és a társadalmi modernizációt szolgálja, ugyanakkor a válság- és konfliktuskezelésre is alkalmas;

2. Meg kell teremteni a piacgazdasági átmenet, az önfenntartó, organikus társadalmi erőkből táplálkozó modernizáció politikai feltételeit;

3. A politikai rendszer továbbfejlesztése nem lehet öncél. Rövid távú célja az esetlegesen bénító hatású válság elkerülése, a teremtő-alkotó energiák összpontosítása. Hosszú távú célja a demokratizmus olyan kiteljesítése, amely fordulatot eredményez a társadalmi újratermelési folyamatokban, és ezen keresztül megalapozza a társadalom gazdasági teljesítőképességének növekedését;

4. Meg kell tanulni perspektivikus követelményeket szem előtt tartva - nem pazarló módon - gazdálkodni az emberek szellemi-erkölcsi energiájával;

5. A politikai intézményrendszer fejlesztése, a viszonyok demokratizálódása nem lehet a politikai vezetés privilégiuma. Autonóm társadalmi folyamatok kezdeményező fellépése lehet csak az előrelépés feltétele;

6. A politikai rendszernek nemcsak a gazdaságot, hanem a társadalmat is autonóm jellegủ létezőnek kell tekintenie. A politikai rendszer nem törhet monopóliumra, nem a részletek ellenőrzésével, hanem a fö folyamatok orientálásával kell foglalkoznia;

7. A demokratizmus kibontakozását a politikai hatalom olyan legitimációjával kell alátámasztani, amelyben vezérlő etikai értékek fontos 
szerepet töltenek be. A demokratikus kibontakozás nemcsak a politikai intézményrendszer kohézióját biztosítja, hanem újfajta társadalmi integrációt is jelent;

8. A politikában tudomásul kell venni a társadalom érdektagozódását, a politikai rendszerben meg kell szüntetni az érdekképviselet hiányosságait és az érdekegyeztetési mechanizmusok erőtlenségét és formalizmusát.

Végkövetkeztetésként a civil szervezetek kapacitáskérdésében a következő kijelentéseket lehet megfogalmazni:

- A rendszerváltás után mind Magyarországon, mind Romániában a civil társadalom szerepe megerősödött.

- A civil szervezetek aktív résztvevői a közpolitika-csinálásnak (a policymaking folyamatoknak) mind helyi, regionális, mind nemzeti szinten.

- Egyes szakmai civil szervezetek aktív résztvevői a közszféra 1989 óta tartó reformjának és modernizációs folyamatának, viszont hatással is vannak e folyamatokra. Ha figyelembe vesszük, hogy a civil szervezetek egyik fö jellemzője az érdekképviseleti, érdekvédelmi tevékenységek felvállalása, kijelenthető, hogy mind Romániában, mind Magyarországon a demokrácia útján járó kormányok egyik „felügyelő” szerve az aktív, mindig cselekvésre kész civil szektor volt. Mindebböl leszürhető, hogy a civil szféra állandó intézményfejlesztési, modernizációs igénye hatással van a közigazgatás müködésére, fejlődésére.

- A civil szervezetek nem csak hatással vannak a közigazgatásra, hanem konkrét közpolitikai szereplökként is megjelennek. Itt nem csak szolgáltatásnyújtásra kell gondolni, hanem konkrét részvételre is az olyan közpolitikai döntésekben, amelyek a közösségeket közvetlenül érintik. 


\subsection{Együttmúködés és eredményesség a határ menti térségekben}

A határ menti együttmüködés intenzitása, a pályázatok eredményessége fontos kiindulópont lehet akciókutatásunk javaslataihoz. A kutatás végén a kutatási területről kiválasztott intézmények együttmüködési és eredményességi tapasztalatai alapján javaslatokat készítünk arra vonatkozóan, hogyan lehetne erősíteni a térségben a határ menti együttmüködést.

Ha az együttmüködés intenzitását a két ország határ menti térségében idősávokba próbáljuk sorolni, akkor egy általános képet kaphatunk az együttmüködés nagy időszakairól. Mivel számos időszakra vonatkozóan nem léteznek írott dokumentumok, együttmüködést igazoló okmányok, ezért nehéz idősávokban meghatározni vagy konkrét példákkal leírni az együttmüködést leíró folyamatokat. Elmondható, hogy az együttmüködések történelmi időkben nehezen mérhetőek.

Mégis, ha a határ menti együttmüködések intenzitását szeretnénk időkeretekben rangsorolni, véleményünk szerint három fő időszakról beszélhetünk:

1. A '89 elötti idöszak, melyet alacsony intenzitású együttmüködési (low intensity cooperation) időszaknak nevezünk. A rendszerváltás előtti Romániában a határ mint elválasztó fogalom - barrier (gát) - létezett, azonban ez sem akadályozta meg az emberek közötti együttmüködést. Az intézmények közötti kapcsolatok teljes mértékben tiltottak voltak és nem léteztek határon átnyúló intézményi kezdeményezések. Az intézmények közötti kapcsolatok a '89-es rendszerváltás előtt nehezen müködtek, a kommunista rezsim vezetői fenyegetőnek tartották és rendszerellenes tevékenységnek nyilvánítottak mindenféle határon átnyúló kezdeményezést.

Ezen időszakban olyan kapcsolatok voltak, amelyek megfelelnek a hierarchikus kritériumnak: 
- $\quad$ A kapcsolatok nem országos szintüek, tehát a központi szerveknél alacsonyabb szinten szerveződnek és müködnek (persze ez nem zárja ki a kormányzati szereplők részvételét, de szerepük nem elsődleges a szervezésben).

A kapcsolatok résztvevőinek működési területe egymással összekapcsolódó határ menti térségben található. A határ menti térség fogalmán azt a területet értjük, amelynek mindennapi életére jelentős befolyást gyakorol valamely államhatár.

2. 1989-1996 között közepes intenzitású együttmüködési időszakról (middle intensity collaboration) beszélünk. Ez a periódus mindkét határ menti övezetben a demokratizálódás felé vezető út keresésével telt. Az állami szervek ebben az időszakban egyre több feladatkört ruháztak a helyi közigazgatási szervekre.

A civil szféra az idő tájt még gyerekcipőben járt. Azonban ebben az időszakban elkezdődnek az első non-formális együttmüködések: testvértelepülési szerződések létesülnek, határ menti tematikus látogatások valósulnak meg (egyházak, ifjúsági szervezetek stb.), és egyre intenzívebb érdeklődés mutatkozik az iránt, hogy ezen együttmüködéseket magasabb szintre helyezzék. Ebben az időszakban már a határ egyesítő erejéről beszélhetünk, az akadályokat sikerül elhárítani az együttmúködés útjából. Ezt a kijelentést erősíti meg Baranyi Béla, aki szerint a '90-es években végbemenő politikai változások számos új lehetőséget, „összekapcsolási” kényszert váltottak ki, viszont egy másik folyamat is megjelenik, mégpedig az „elválasztó” jelleg. Az euroatlanti integrációs folyamatok rávilágítottak, hogy az összeurópai modellnek nincs reális alternatívája. A csatlakozás rendkívül gyötrelmes és hosszú távú folyamat volt, többek között ezért került előtérbe Közép- és Kelet-Európában, valamint a Kárpát-medencében is a regionális együttmüködés kérdésköre (Baranyi Béla, 2007:3-21). 
3. Az 1996-tól napjainkig tartó időszak méltón nevezhető a maximális intenzitású együttmüködés (maximum intensity collaboration) időszakának. Elkezdődtek az előkészületek és megvalósultak az első PHARE CBC, majd az INTERREGpályázatok. Magyarország 2004-es csatlakozásával a magyarországi pályázók az INTERREG forrásból részesültek, míg a román partner a PHARE-t pályázhatta. 2008 óta közös projektek valósulhatnak meg az új Területi Együttmüködési Program keretéből, mely helyettesíti a PHARE CBC és INTERREG alapokat.

Véleményem szerint olyan folyamatok mentek és mennek végbe a határ menti övezetben, melyek nincsenek fizikai határokhoz kötve. Az utóbbi évtizedek politikai változásai felerősítették az együttműködéseket, és a baráti, illetve családi kapcsolatok, melyek az 1989 előtti időszakot jellemezték, a rendszerváltások után hozzájárultak a testvérvárosi kapcsolatok kiépüléséhez. Ezen kapcsolatok, együttmüködési formák fő jellemzője, hogy intézményesült kapcsolatokról van szó. A spontán, föként kulturális, területi, földrajzi szempontok alapján kialakult együttműködéseket követően elérkezett az együttmüködések csúcspontja, vagyis az európai uniós alapok megpályázása, melyek lehetőséget teremtettek nem csupán intézményi együttmüködésre, hanem közös fejlesztések megvalósítására is.

A fejezet további részében be szeretnék mutatni néhány olyan konkrét pályázatot, amelyek véleményem szerint fenntartható eredményeket voltak képesek létrehozni. Nem csak a magyar-román határszakaszról mutatunk be pályázatokat, hanem a magyar-szlovák határ mentéről is, hiszen véleményünk szerint a magyarszlovák határ mentén számos olyan kezdeményezés és eredmény született, melyek a magyar-román határ mentén is jól alkalmazhatóak lennének.

Az alábbiakban bemutatásra kerülő pályázatok kiválasztási szempontja az indikátor szám, tehát olyan pályázatokat mutatunk be, amelyek a kutatásban 
magas indikátor számot értek el, viszont olyan pályázatok is bemutatásra kerülnek, melyek nem vettek részt a kutatásban (például a magyar-szlovák pályázatok, hiszen az indikátor csak a magyar-román határ mentén megvalósult pályázatokat vizsgálta).

Az első projekt, melyet be szeretnék mutatni, Szatmárnémeti és Nyíregyháza városok önkormányzatai között valósult meg. A pályázat címe „Nyíregyháza és Szatmárnémeti testvérvárosi együttmüködésének széles körü fejlesztése”. A projekt teljes költsége 129.029,35 euró, melyböl 4.522,41 euró az önrész.

A projekt célja a testvérvárosi együttmüködés széles körü fejlesztése. A projekt részeként öt alkalommal került sor együttmüködésre a kultúra, ifjúság, fejlesztés, gazdaság és szociális területeken, mely egyrészt a Nyírségi Ősz jellegzetességeire koncentrált, ahol Nyírbátor saját gyümölcskompozícióval és zenés csoporttal vonult fel.

A Nemzeti ízek utcája címü rendezvény keretén belül neves szatmári különlegességeket kóstolhattak meg az érdeklődők. A képzőmüvészeti kiállítás keretében pedig profi müvészek mutatták be alkotásaikat. Sor került a civil szervezetek bemutatkozására a Civilek utcája címü rendezvény kapcsán, a közösségfejlesztés előmozdításának elősegítése érdekében. A környezetvédelem területén a Panel Program elvi és gyakorlati tapasztalatainak átadására is sor került, valamint megszervezték az Eco vetélkedőt a középiskolás gyerekek részére. Szociális szakemberek találkozójára és fogyatékkal élő fiatalok együttmüködésére is sor került, melynek keretén belül megszervezésre került többek között a Speciális (fogyatékos) Olimpia is.

A Szatmárnémetiben megrendezésre kerülő Városnapok keretében Barátságos futballmérkőzésen mérték össze tudásukat a közterület-fenntartók és a Rendőrség képviselői. A projekt révén közelebb kerültek egymáshoz a program résztvevői, ezáltal elősegítve a térség közös fejlesztését. 
Egy másik sikeres projekt a magyar-szlovák határ mentén valósult meg, és a „Határon átnyúló információs együttmüködés: Crossing Borders by Information in the Pons Danubii Border Region (Révkomárom)" címet kapta.

A projektet az első szlovák székhellyel rendelkező EGTC, a Pons Danubii valósítja meg (még nem zárult le a pályázat) a magyar-szlovák határ mentén. A Pons Danubii EGTC 2010 decemberében jött létre, hat város a tagja, ebből három a magyar oldalról (Komárom, Tata, Kisbér) és három önkormányzat a szlovák oldalról (Komárom, Gúta, Újgalla).

Az EGTC fő célja, hogy fejlesztési projekteket kezdeményezzen és valósítson meg, ezáltal erősítvén a települések közti határon átnyúló együttmüködést. Jelenleg az EGTC egy főállású igazgatóval rendelkezik Bara Zoltán személyében, valamint egy irodavezetővel. Egyes konkrét feladatok ellátására együttműködnek szakértőkkel, továbbá gyakornoki programot is szervez az EGTC.

Az EGTC több pályázat előkészítésén dolgozik, kiemelhető az idegenforgalmi és turisztikai pályázat, mely egy nagy régiós turisztikai programot kiván megvalósítani a Duna mentén, a magyar-szlovák határszakaszon (partner EGTCk:Arrabona, Ister-Granum és Pons Danubii).

A Pons Danubii más területeken is készít elő projekteket, mint például a munkaerőpiac, a megújuló energiaforrások használata és a vízgazdálkodás. Az EGTC távlati célja az, hogy közszolgáltatásokkal is segítse a helyi lakosok életét, és már meglévő, illetve elökészített projektjeikben is megjelennek ezek egyes elemei. Kiemelhető ezek közül az egészségügy, valamint az oktatásügy, hiszen ezeken a területeken számos olyan együttmüködési lehetőség van, ahol a határokat figyelmen kívül hagyva közösen kívánják ezen szolgáltatásokat fejleszteni, és mindenki számára egyformán elérhetővé tenni. Az életben gyakorlati szinten mindennap merülnek fel olyan problémák, kérdések, melyek megjelennek a határ mindkét oldalán, és az EGTC egyik fö feladata, hogy ezekre 
a közös problémákra egy összekapcsolt, határon átnyúló választ és jövőképet adjon.

Az EGTC megalakítása folyamán szervezett tematikus munkacsoportok találkozóján a média volt az egyik fö probléma, mely felismerést nyert. Az újságírók, internetes médiában dolgozók, rádiók és TV-k képviselői úgy érezték, hogy szükség volna egy hálózati együttmüködésre, mely a határ mindkét oldaláról egy helyre gyüjtené a kiemelkedő híreket. Ezáltal a magyar és a szlovák területen élök egyaránt napi szinten értesülhetnének aktuális információkról a határ másik oldaláról, mégpedig saját nyelven, ugyanis a napi hírek magyar és szlovák nyelvekre lesznek lefordítva és közvetítve a lakosságnak.

$\mathrm{Az}$ anyagok feliratozva kerülnek vetítésre, és két éven keresztül megoldott e programok levetítésének finanszírozása és megvalósítása. A pályázat nyolc városi televízió együttmüködéséről szól. Az EGTC reményei szerint a projekt lezárása után (november 2014.) is folytatni fogják ezt a kezdeményezést a helyi televíziók. A Pons Danubii eddigi tevékenységéböl és a fentebb bemutatott projektböl is látható, hogy egy olyan szervezet, mint az EGTC, kevesebb, mint egy évi müködés eredményeképpen számos olyan problémára képes megoldást találni, amelyekre az önkormányzatoknak nincs elegendö kapacitása (ennek több oka is lehet, például pénzügyi vagy humánerőforrás hiány, a határ víziója mint elválasztó elem stb.)

Fontos megemlíteni, hogy az EGTC tevékenységi területének nem lehet határt szabni, hiszen az EGTC fö feladata - mint azt a Pons Danubii példája is mutatja , hogy fejlesztést hajtson végre, bármilyen területröl is legyen szó. Problémás területek ugyanis vannak, csak fel kell ezeket ismerni (a Pons Danubii esetében például az egészségügy, vízgazdálkodás, területfejlesztés, turizmus, gazdaság, energia stb.).

A komplex fejlesztések kivitelezésében, valamint a projektek összeállításához és sikeres végrehajtásához mindenképpen szükség van arra, hogy ezeket egy 
szervezet összefogja és kezelje. Ahhoz, hogy komplex programok, fejlesztések valósuljanak meg a határ mindkét oldalán - legyőzve a különböző jogi akadályokat, a gazdasági és szociális környezet különböző kihívásait -, szükség van egy olyan szervezetre, amely a projekteket megvalósítja. Eddig kevés olyan szoros együttmüködés és intézményi forma alakult ki határon átnyúló jelleggel, mint az EGTC. Ahhoz, hogy közszolgáltatásokat tudjon nyújtani egy EGTC, nagyon fontos, hogy összehangolva legyenek a fő problémák (Ocskay Gy., 2012:Konferencia Paper Nagyvárad).

A következő bemutatásra kerülő projekt címe „AGGLONET - Magyar-szlovák agglomeráció Pozsony környékén - Közszolgáltatás-fejlesztési hálózat Pozsony határon átnyúló agglomerációjában (Győr-Somorja)".

A projektet a Magyar Tudományos Akadémia Regionális Kutatások Központja, Nyugat-magyarországi Tudományos Intézete (Győr) és a Fórum Kisebbségkutató Intézet (Somorja) valósította meg a 2009. szeptember 1. és 2010. október 31. közötti időszakban. A projekt megvalósítását az Európai Regionális Fejlesztési Alap, Magyarország-Szlovákia Határon Átnyúló Együttmüködési Program 20072013 támogatta.

Az AGGLONET projekt elkészítését két fó probléma indokolta: a schengeni csatlakozást követően a térségbe költözött szlovák állampolgárok száma megnövekedett, így egy olyan migrációs folyamat kezdödött, mely nem volt jellegzetes a régióban. Egy másik probléma, mely valamilyen megoldásra vár jelenleg is, a közszolgáltatások, melyekből a beköltözött szlovák állampolgárok részesülnek.

Ez föként az önkormányzatok problémája, hiszen a telekadók és házadók, vagy más helyi adók problémája kérdéses külföldi állampolgárok esetében, és az önkormányzatoknak kell az egyes közszolgáltatásokra is többletforrásokat elkülöníteni (itt olyan közszolgáltatásokról van szó, amelyek ingyenesek a 
magyar állampolgároknak, és ezek ellátására állami kvótát kapnak az önkormányzatok vagy nemzeti költségvetésből vannak támogatva, mint például az oktatás-nevelés, egészségügy, szociális ellátás stb.).

A jelenség nem volt más, mint egy szuburbanizációs folyamat, mely a nagyvárosok gyors fejlődéséhez kötődik, viszont a magyarországi önkormányzatok nem egy tipikus, országon belül történő migrációval találták szembe magukat, hanem külföldi állampolgárokkal. Az önkormányzatoknak nem csak a migrációs folyamat következtében felmerülő többletköltségek elöteremtésével kellet foglalkoznia, hanem például szlovák nyelven kellett biztosítania egyes szolgáltatásokat és információnyújtást.

A kutatás egyik célja az volt, hogy megismertesse a magyar önkormányzatok problémáit, melyek abból adódtak, hogy beköltöztek a szlovák állampolgárok, másrészt pedig hogy felmérje, milyen problémákat tapasztaltak a Magyarországra költözött szlovák állampolgárok.

A pályázat keretén belül megvalósított kérdőíves felmérés rámutatott arra, hogy a Magyarországon élő szlovákok nem érzik magukat semmivel sem rosszabbul, mint ha Szlovákia bármely más területére költöztek volna ki Pozsonyból. A kutatás egy másik célja az volt, hogy egy határon átnyúló önkormányzati együttmüködést hozzon létre. Ennek érdekében a pályázatban három magyar és három szlovák önkormányzat is részt vett, mint nem támogatott partner. A projekt eredményeként létrejött egy AGGLONET nevezetủ hálózat, melynek feladata, hogy a projekt keretében felismert problémákra megoldást találjon.

A projektben megvalósított kutatás számos, eddig nem létező adatot, problémát és információt hozott elötérbe. A projekt keretein belül megvalósított tanulmányban javaslatok születtek a közigazgatás rendelkezésére álló eszközök kihasználására, a hálózatok által nyújtott lehetőségek kiaknázására, a határon átnyúló új közforgalmú közlekedési modell alkalmazására, továbbá elemzésre kerültek a fő problémás területek, mint például az oktatás és egészségügy. 
A felismert problémák egyik lehetséges megoldása egy új, közös magyar-szlovák EGTC alapítása volna, hiszen egyes közszolgáltatásokat a határ menti önkormányzatok közösen el tudnának látni. Ezáltal a közszolgáltatások minősége javulna, és ez nem csak a magyar vagy csak a szlovák állampolgároknak jelentene minőségi változást, hanem az egész övezetben élőknek lehetősége volna minőségi közszolgáltatásokban részesedni.

Az új intézmény - az EGTC - átvállalhatna egyes közszolgáltatásokat, melyeket jelenleg az önkormányzatok látnak el, és ezáltal határon átnyúló jelleggel, mint egységes szolgáltató jelenne meg az EGTC. Ilyen közszolgáltatások lehetnének például az oktatás-nevelés, az ifjúsági és közösségi tevékenységek, valamint az egészségügyi alapellátás. Ehhez viszont szükséges egy elhatározás és a két ország törvényeinek vizsgálata annak érdekében, hogy felismerjék, melyek azok a közszolgáltatások, melyeket az önkormányzatok átruházhatnának egy EGTCnek. Az új intézmény sokkal egyszerübben tudna reagálni és megoldást találni a településeken felmerülö egyes problémákra, melyekre az önkormányzatok megfelelő humánerőforrás és pénzügyi keretek hiányában nehezebben reagálnak (Ocskay Gy., 2012:Konferencia Paper Nagyvárad).

Egy másik sikeres pályázat „Nonprofit szakmai támogató szolgáltatások müködtetése Szatmár megyében" címmel lett megvalósítva. A projekt Lead Partnere a nyíregyházi Regionális Érdekvédelem Alapítvány. A projekt célja a határok menti együttmüködés kialakítása a civil társadalom fejlesztésével a romániai szociális problémákkal és munkanélküliséggel foglalkozó civil szervezetek körében, valamint Nyíregyházán és Romániában szervezett képzések és pályázati tanácsadások megvalósításával. 
Cél volt továbbá jól müködő, alternatív munkaerőpiaci programok adaptációjának előkészítése, valamint az állandó és naprakész információcsere lehetőségének megteremtése weblap és elektronikus hírlevél formájában.

A képzéssorozaton részt vevő 20 romániai civil szervezet képviselője elsajátította az alternatív, munkaerőpiacra „visszajutást” elősegítő projektek megtervezéséhez és megvalósításához szükséges ismereteket.

A projekt további eredményei közé sorolhatóak a projekt müködése során kialakult kapcsolatok és együttmüködések, melyek elsősorban a tréningeknek és tanácsadásoknak köszönhetőek, ahol a résztvevőknek alkalma nyílt megismerni egymás céljait, tevékenységeit és célcsoportjait. Erősödött a romániai civil szervezetek feladat- és küldetéstudata, valamint belső munkaszervezete, és ezáltal növekedett szakmai hatékonyságuk, és legföképpen pályázataik színvonala és eredményessége. A program hatására fokozódott a határ két oldala közötti információáramlás a sajtó és az internet közvetítésével, továbbá közös, határon átnyúló projektek vannak készülöben.

A képzéssorozaton átadott ismeretanyagnak és a pályázati tanácsadásokon nyújtott szakmai segítségnek köszönhetően 11 pályázatot nyújtottak be. A projekt végrehajtói nem csupán 10 hónapra kötöttek egymással szerződést, hanem mindent megtettek a további sikeres együttmüködésért. Ennek érdekében már benyújtásra került egy pályázat, melynek célja a jelenlegi program által elindított törekvések folytatása.

A Szatmár-Beregi Szilva Út Egyesület a Szatmár-Beregi Pálinka Lovagrend Egyesület és a romániai Szatmár Megyei Agrár, Kereskedelmi és Iparkamara partnereként a Magyarország - Románia Határon Átnyúló Együttmüködési Program keretein belül „Szilvaturizmus - A szilva, mint összekötő kapocs a szatmári vidék turisztikai fejlesztésében" címmel közös projektet valósított meg. A projekt célja a térségben rejlő turisztikai potenciál minél nagyobb mértékü 
kiaknázásának elösegítése volt, valamint közösségi marketingtevékenység folytatása a szilva, mint közös motívum segítségével. A projekt teljes összköltsége 212116 EUR, a megvalósítása 2009. december 1-én kezdődött és 2011. július 31-én fejeződött be.

A projekt keretében került sor Magyarországon a „Szatmári szilva háza” és tájjellegü fajtagyüjtemény létrehozására, Romániában pedig Szatmári szilva bemutatóhely került kialakításra. A bemutatóhelyek kialakítása mellett egy termékfejlesztési folyamat során elkészült a Szatmár-Szatmár Szilvaút tematikus turisztikai útvonal, mint önálló termék programja, koncepciója, illetve közös marketing tevékenység került megvalósításra.

A Szilva Út Egyesület a programalkotásban, illetve a közös marketing tevékenység során a rendezvények szervezésében és lebonyolításában, a szakmai tanulmányutak lebonyolításában, a turisztikai kiadványok és a bemutatófilm készítésében vállalt vezető szerepet, valamint egy meglévő weboldal került kibővítésre egy online turisztikai adatbankkal, illetve a Szatmár-Szatmár Szilva utat bemutató weboldallal, és a projekt során megvalósult fejlesztésnek köszönhetően a magyar mellett már román nyelven is elérhetőek az információk.

Egy másik érdekes projekt a Szatmár megyei Europrojekt Egyesület és Szakoly Önkormányzat közös pályázata. A projekt címe „Közös értékek, közös tevékenységek, az európai fiatalok multikulturális tapasztalatai”, a projekt megvalósítására a 2006 szeptembere és 2007 augusztusa közötti időszakban került sor. A projekt összköltségvetése 43.395,28 euró volt. A fő tevékenységek a képzés és fejlesztés az európai uniós politikák terén, valamint a partnerek közötti tapasztalatcsere voltak.

A kultúrák közötti tapasztalatcserére került sor a magyarországi szakolyi és a romániai szatmárnémeti fiatalok között a színház, tánc, versenyek, fotókiállítások, 
interkulturális vetélkedők, hagyományok terén, melyeken 40 fiatal vett részt Szatmárnémetiböl és 30 fiatal Szakolyból.

A projekt végső tevékenységeként prospektusokat adtak ki annak érdekében, hogy a gyakorlatban is terjesszék a megszerzett tapasztalatokat. Érdekesnek mondható a kezdeményezés, hiszen egy civil szervezet - mely a közigazgatási dolgozók és fiatalok ismereteinek fejlesztését tüzte ki célul -, valamint egy önkormányzati szervezet partnerségével valósult meg a projekt. A két szervezet jelenleg is valósít meg közös projekteket és több mint 7 éve dolgoznak már közösen.

Egy másik sikeres magyar-szlovák pályázat 16 partner bevonásával lett megvalósítva. A projekt címe „ABAÚJI turisztika határok nélkül”, a projekt 18 hónap időtartamú volt. A projekt keretein belül több turisztikai iroda és tájház nyílt, turisztikai táblák lettek kihelyezve, közös film készült, szórólapok és plakátok készültek, valamint elkészült egy turisztikai portál, továbbá 16 müsoros rendezvénysorozat került megszervezésre minden partnertelepülésen. A projektet egy nemzetközi turisztikai konferencia zárta le, ahol turisztikai szakemberek ismerhették meg az Abaúji térség még felfedezetlen, gyönyörü tájait és a nagyszerü helyi lehetőségeket.

Mielött a pályázatok elemzésére térnénk rá, fontosnak tartjuk a teljes programterület bemutatását, hiszen a pályázati források e teljes területen képesek eredményt felmutatni, és mivel akciókutatásunk javaslatai nem csak a szük kutatási térre vonatkoznak, ezért fontos a teljes területet megismerni.

Egy másik sikeres projekt Hajdú-Bihar, Szabolcs-Szatmár-Bereg és Szatmár Megyékből származó önkormányzatok partnerségéből állt össze. A partner önkormányzatok Újfehértó Város Önkormányzata, Székelyhíd Város Önkormányzata, Nyíradony Város Önkormányzata, valamint Kiskereki Község 
Önkormányzata. A pályázat címe: „Érték-határ: Innovatív határon átnyúló közösségi szolgáltatási rendszer kialakítása“.

A pályázat 2011 márciusa és 2012 márciusa között valósult meg. A pályázat összköltségvetése 219.252 euró, melyböl 186.634,20 euró az Európai Regionális Fejlesztési Alapból származik.

A pályázatban elkészült a két magyarországi település, Nyíradony és Újfehértó gazdálkodási és feladat-ellátási modellje. Az elemzés során óhatatlanul szükségessé vált a települések körüli terület, a kistérség feltérképezése.

A projekt elsődleges célja, hogy az Érmellék és a Nyírség területén lévő önkormányzatok, valamint a civil és a gazdasági szféra képviselői között valós, és minden fél számára kölcsönösen elönyös együttmüködések jöjjenek létre, a köztük lévő határvonalon felülemelkedve.

A projekt első lépéseként a partnertelepüléseken, az újfehértói modell által kijelölt szempontrendszer alapján lezajlott a feladat-ellátási rendszerek vizsgálata szervezeti és finanszírozási szempontból, feltérképezve a helyi értékeket és érdekeket. Elemző tanulmányok készültek mind a magyar, mind pedig a román jogi és finanszírozási környezetről.

Az elemző tanulmányokból kiindulva az önkormányzati döntéshozók és partnereik közösen meghatározták azokat a témaköröket, amelyek tekintetében elképzelhetőnek tartották a települési feladat-ellátás szintje felett történő együttmüködést, valamint a civil szervezetek bevonását, ezzel javítva a szolgáltatás színvonalát, és a szinergiában rejlő előnyök kihasználásával növelve a müködés hatékonyságát.

Az elkészülő négy rendszertanulmány együttesen alkotja az átfogó települési menedzsmentstratégiát, valamint a határon átnyúló, térségi szemléletü bővítéslehetőségét, alapjául szolgálva a jövőbeli intézményi fejlesztéseknek. 
Egy másik pályázat, mely oktatási témában valósult meg a „MagyországRománia határon átnyúló együttműködés keretében megvalósuló tananyagfejlesztés és gazdaképzés" címmel került megvalósításra. A pályázat összköltségvetése 99.724 euró, ebböl 84.765,40 euró az Európai Regionális Fejlesztési Alapból származik.

A mezőgazdasági termelés eredményességét napjainkban döntő mértékben az emberi tényező határozza meg. Az agrárium szereplőinek szakmai felkészültsége régiónkban sajnos messze elmarad az Európai Unió nyugati felében megszokott és joggal elvárható szinttől. A gazdaképzés szükségességét tehát a legfontosabb tényezők között kell említenünk.

Az ismeretátadáson alapuló gazdaképzés korábbi gyakorlata a hagyományos és iparszerü intenzív mezőgazdaság igényeit tükrözte. Napjaink többfunkciós mezőgazdasági termelésében kiemelten fontos jelentősége van a környezet megóvását biztosító fenntarthatóságnak. Fokozottan igaz ez a Szatmári-síkságon a határon inneni és túli mezőgazdasági termelésre, mert ebben a régióban a természeti értékek védelmét csak környezettudatos mezőgazdasági termeléssel lehet biztosítani. Ezért van szükség a régió adottságaihoz igazodó, a környezeti értékeket szem előtt tartó, ökológiai szemléletü, új technológiai megoldásokat bemutató tananyagfejlesztésre a gazdaképzésben.

A jelenleg ismert és akkreditált gazdaképzési programok modulrendszere jelentősen átalakult az elmúlt néhány évben. A rendelkezésre álló régi tankönyvek és oktatási segédletek nem tükrözik az új modulrendszerben megfogalmazott igényeket. A pályázatban tervezett tananyagfejlesztés igazodik a jelenlegi képzési követelményekhez, és egyben tartalmazza a régió speciális igényeinek megfelelő új szemléletet és ismeretanyagot.

A pályázatban megvalósított tananyagfejlesztés igazodik a Nemzeti Fenntartható Fejlödési Stratégia azon eleméhez, miszerint: "Az oktatás tartalmaiban és formáiban hangsúlyosabban kell megjeleníteni a fenntarthatósági témákat és 
értékeket. A fenntarthatóságnak alapkövetelménnyé kell válnia az új ismeretek befogadása és a változó társadalmi és gazdasági viszonyok közötti eligazodás érdekében. Fontos a fenntarthatóság összes vetületével kapcsolatos ismeretek terjesztése és fejlesztése (óvodai nevelés, iskolarendszerü oktatás, képzés, iskolarendszeren kívüli oktatás és továbbképzés, müvelődés, ismeretterjesztés, könyvkiadás)."

A pályázat kapcsolódik a társadalmi és gazdasági kohézió erősítése a határ menti térségben prioritási tengely 2.3. Együttmüködés a munkaeröpiacon, oktatásban készségek, ismeretek közös fejlesztése tevékenységhez. A tevékenységek során megvalósított tananyagfejlesztés szervesen illeszkedik a humán erőforrás képességeinek javítása a fenntarthatóság elve alapján célkitüzéshez, és közvetve hozzájárul a fenntartható területi fejlődéshez.

Az oktatók mint kedvezményezettek számára a tananyagfejlesztés lehetőséget és naprakész programot nyújt az oktatásban. A gazdák számára a tananyagfejlesztés a szorosan vett szakmai ismereteken túl lehetőséget nyújtott a fenntartható mezőgazdasági tevékenység specifikumainak elsajátítására. Ezáltal képessé váltak az Európai Unió által szorgalmazott és pályázati lehetőségekkel támogatott környezettudatos mezőgazdasági termelés folytatására.

A pályázat Fő Partnere (Lead Partnere) a Nyíregyházi Főiskola Müszaki Mezőgazdasági Kar és a Nagykárolyi Mezőgazdasági Szakközépiskola és Szakiskola jogutódja, a Mezőgazdasági Iskola Központ. Több évtizedes múltra tekint vissza mindkét intézmény a mezőgazdasági oktatás, a mezőgazdasági szakemberképzés terén. Infrastruktúrájuk, labor és mühelyhátterük alkalmas a szakemberképzésre. A partnerintézmények dolgozói a projektben mint a gazdatanfolyamok szervezői és oktatói vettek részt. 


\subsection{A programterület és vizsgált övezet bemutatása}

A támogatásra jogosult határ menti terület Magyarország délkeleti és keleti, illetve Románia északnyugati és nyugati területeit foglalja magában. Négy-négy egymással szomszédos magyarországi, illetve romániai megyéből áll, a magyarországi megyék ${ }^{10:}$ Szabolcs-Szatmár-Bereg, Hajdú-Bihar, Békés és Csongrád, az érintett romániai megyék: Szatmár (Satu Mare), Bihar (Bihor), Arad és Temes (Timiş)

A nyolc érintett megye (NUTS III szint) az alábbi négy régióba (NUTS II szint) tartozik:

- Szabolcs-Szatmár-Bereg és Hajdú-Bihar megye az Észak-alföldi Régió része (Magyarország), Békés és Csongrád megye a Dél-alföldi Régióhoz tartozik (Magyarország).

- Arad és Temes megye a Nyugati Régióhoz tartozik (Románia).

- Szatmár és Bihar megye az Északnyugati Régió része (Románia).

Földrajzilag a román-magyar határ menti terület a Kárpátok hegység és a Kárpátmedence részét képezi. Magyar oldalon a teljes terület az Alföld része, míg a román terület több részből tevődik össze: a nyugati Román-alföld, a Nyugatihegység, illetve a Nyugati-Kárpátok (Munţii Apuseni) kisebb része is ide tartozik. A határ menti megyéket több folyó szeli át, amelyek Romániában erednek és Magyarországon ömlenek a Tiszába (a Maros, a Körös, a Berettyó és a Szamos). Mivel ezek a folyók összekötik egymással a szomszédos megyéket, különleges lehetőséget kínálnak a határon átnyúló együttmüködésre.

${ }^{10}$ A fejezetben található információk többsége a Magyar-Román Operatív Program, a CESCI és saját megfigyelésből származó adatok 


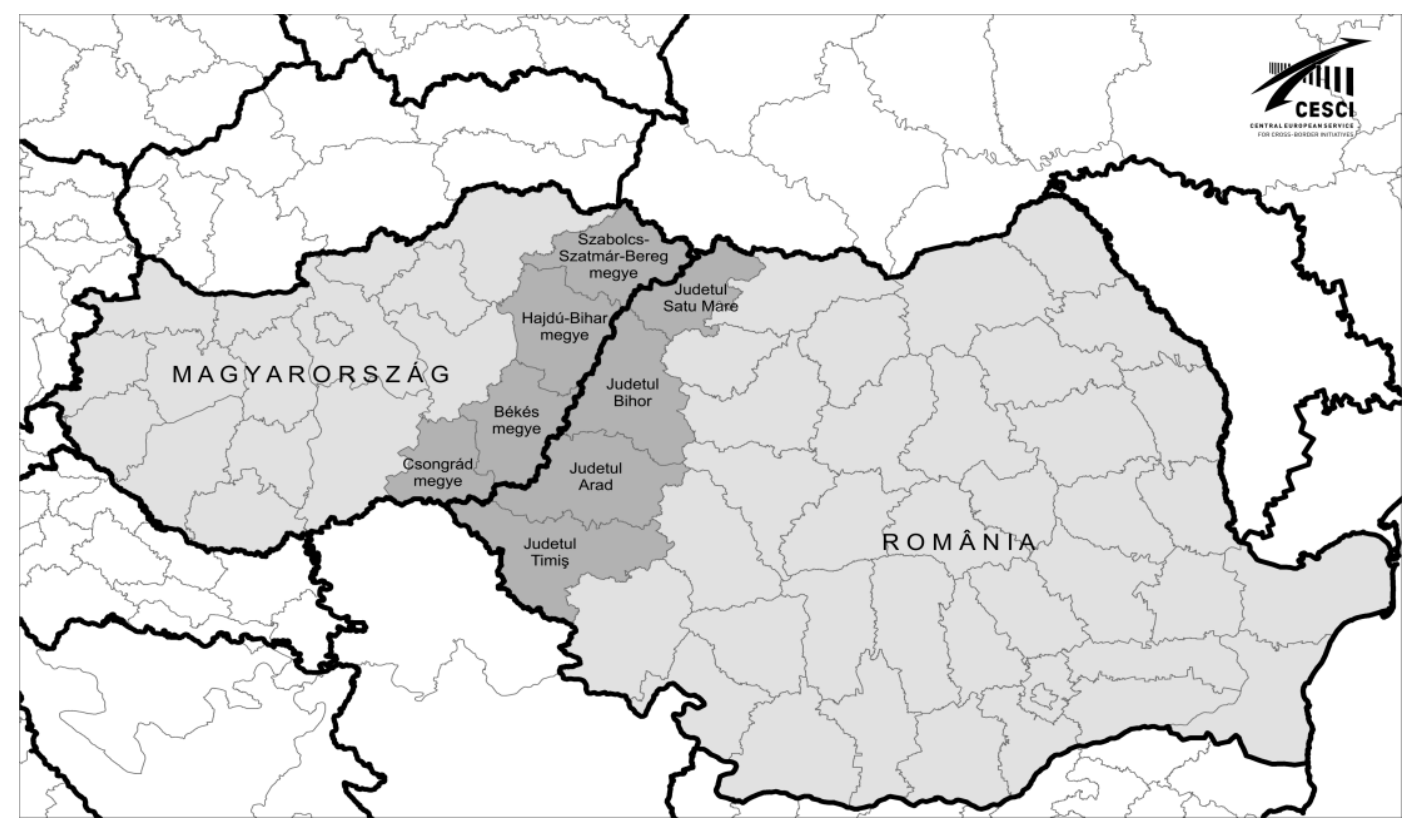

2. számú térkép: A magyar-román határ menti övezet (Forrás: Central European Service for Cross Border Initiatives)

A román-magyar államhatár teljes hossza 448 km, ebből 415,8 km szárazföldi, 32,2 km pedig folyami (a Maros, Körös és Szamos folyókon). A nyolc megye összterülete $50.454 \mathrm{~km}^{2}$, ennek 43,7\%-a Magyarország és 56,3\%-a Románia területének része.

A magyar övezet Magyarország összterületének 23,7\%-a, a romániai térség Románia összterületének 11,9\%-a. 2004-ben a térség összlakossága meghaladta a négymillió főt, amelynek csaknem fele Magyarországon, míg a felénél valamivel több Romániában él. A magyar oldalon Magyarország lakosságának csaknem egyötöde $(19,7 \%)$, a román oldalon pedig a román összlakosság 9,7\%-a él.

Az együttmüködésbe bevont térségben Hajdú-Bihar megyére a legjellemzőbb a városias jelleg annak ellenére, hogy több városa korlátozott városi funkciókkal rendelkező, nagy kiterjedésü, mezőgazdasági jellegü település. A népsűrüség 
valamennyi megyében az EU25 átlaga alatt van $\left(118\right.$ fö $\left./ \mathrm{km}^{2}\right)$, ami a térség föként vidéki jellegét tükrözi.

A legalacsonyabb a népsürüség Arad megyében, a legmagasabb Csongrád megyében. Az elvándorlással kapcsolatos tendenciák Arad és Temes megyében pozitívak, míg a térség többi részében a mutatók - eltérő mértékü - negatív értékeket jeleznek, ami kedvezőtlen változásokra utal. Ehhez társul a természetes népességfogyás, ami nem csak a programba bevont térségre, hanem a két ország egészére jellemzö.

$\mathrm{Az}$ együttmüködésbe bevont térség általános gazdasági fejlettsége az EU25 átlagához képest igen alacsony. A két országon belüli többi övezetet összehasonlítva ugyanakkor elmondható, hogy az együttmüködésbe bevont térség magyarországi részei az ország többi részéhez képest kevésbé fejlettek, míg a romániai rész Románia viszonylatában a legfejlettebb vidékek közé tartozik. Az egy fốre eső GDP nagyon alacsony a programba bevont területen, ugyanakkor a magyar és román térségek között is eltérések vannak. A fejlettebb magyarországi térségben ez a mutató az EU25 átlagának megközelítőleg 23\%-a, míg a román oldalon kb. $13 \%$-a.

A GDP ágazati megoszlása a legfejlettebb európai régiók szerkezetével összehasonlítva törékeny gazdaságszerkezetre utal, ahol a szolgáltatásoknak nagyobb funkciójuk van, a mezőgazdaság szerepe pedig kevésbé fontos. A határ menti térség gazdaságában a mezőgazdasági termelés rendeltetése fontos, míg a szolgáltatási szektor aránya különösen Romániában alacsonyabb. A magyarromán kereskedelmi kapcsolatok növekvő tendenciát mutatnak. A Hajdú-Bihar megyéből Romániába irányuló export 2000-2004 között 20 millió euróról 50 millió euróra nőtt, Románia a megye teljes exportjából 5,4\%-ot képvisel. A Romániából Hajdú-Bihar megyébe irányuló export ugyanakkor 25 millió euró körüli értéken stagnál, ami a megye teljes importjának 4,6\%-át jelenti. 
A KKV szektor - néhány jól menő, az országos vagy akár a nemzetközi piacra termelő helyi vállalatot leszámítva - viszonylag fejletlen, alacsony szintü technológiai fejlesztés és korlátozott versenyképesség, valamint az üzleti, piaci információk és kompetenciák elégtelensége jellemzi. A hozzáadott érték aránya a termelésben (előállításban) általában mind Magyarországon (25\%), mind Romániában (25\%) az EU átlaga alatt marad (29\%). A mutatót az ipari előállítás valamennyi ágazatában vizsgálva megállapítható, hogy Romániában a textil- és ruházati iparban, az elektronikai és optikai müszergyártásban, valamint a szállítóeszköz-gyártásban, míg Magyarországon a vegyiparban, illetve mindkét országban a bőr alapanyagok és késztermékek előállításában magasabb a hozzáadott érték aránya.

A fenntartható üzleti együttmüködések kialakítása érdekében minőségi üzleti infrastruktúra, müszaki segítség és a vállalkozásoknak - elsősorban KKV-knak nyújtott egyéb szolgáltatások szükségeltetnek, amelyeknek a teljes határ menti térségben azonos színvonalon kell rendelkezésre állniuk. A szóban forgó infrastruktúra és szolgáltatások hozzáférhetőségét illetően nagyok az eltérések a határ menti térségen belül. Ezen túlmenően korlátozott - bár növekvő mértékü az együttmüködés a KKV-k fejlesztését célzó különféle lehetőségek és szervezetek között.

A programba bevont magyarországi terület közüzemi szolgáltatásokkal megfelelően ellátott, egy lényeges kivétellel: a közüzemi csatornahálózatba bekötött lakások aránya az elmúlt években nőtt, azonban még mindig elmarad az országos átlagtól. Az ivóvízhálózat fejlesztése minden megyében elfogadható mértékü, átlagban meghaladja a 90\%-ot.

Romániában a közüzemi infrastruktúra fokozatosan javul, különösen a városokban. A közüzemi vízvezeték- és csatornahálózatba bekötött helységek száma ugyanakkor nem nőtt lényegesen az elmúlt néhány év során, ami nagymértékben akadály a vállalkozások betelepítését célzó bármely fejlesztési 
stratégia esetében. A programba bevont területen a vízvezeték-hálózatba bekötött helységek aránya mindössze 51,5\%, a falvak nagy részében hiányzik az ivóvízhálózat. Az átlagos mutató Temes megyében a legmagasabb (63,6\%), Szatmár megyében a legalacsonyabb (44\%) az ivóvízhálózatra csatlakozott helységek arányát illetően. A közüzemi szennyvízhálózat szintén fejlődött az elmúlt évek során, de az összes településnek még mindig csupán 42,7\%-át érinti. A legalacsonyabb és legmagasabb ez az arány Szatmár (39,6\%), illetve Temes megyében (55\%). A szennyvízhálózat általában elavult és kapacitása nem kielégítő.

A határtérség egyik gyengesége, hogy a munkaerő-piaci együttmüködés nagyon alacsony szintü. A térség bizonyos területein a munkanélküliség elég nagy méreteket ölt, ugyanakkor közvetlenül a határ mentén a nagyobb gazdasági központok esetenként munkaerőhiánnyal küzdenek (ez jellemző Temesvárra).A térség fontos erősségeként könyvelhető el, hogy számos felsőoktatási intézménnyel rendelkezik.

$\mathrm{Az}$ intézmények minőségi oktatást nyújtanak és a kutatás-fejlesztési tevékenységhez is bázisul szolgálnak. Az egyetemek, valamint az egyetemek és a vállalkozások közötti együttmüködés szintje azonban alacsony, mely a határtérség versenyképes és integrált fejlődésének újabb gátját jelenti.

A turizmus fontos szerepet tölt be a két ország kapcsolatrendszerében, s a közös fejlesztéshez is megfelelő alapot nyújt. Ugyanakkor ez a potenciál nincs kellően kihasználva: a térség nem rendelkezik közös turisztikai programcsomagokkal, s közös marketing és promóciós tevékenységet sem végez.

A határtérség természeti környezete sajátos jelleget ölt: egyrészt számos természetvédelmi terület fekszik a határ mindkét oldalán, másrészt azonban a korábbi nehézipari tevékenység következményeként komoly környezeti károkkal sújtott és szennyezett területek is megtalálhatók. 
A határ menti övezetben a magyar részen fejlett szolgáltató szektor müködik (beleértve az egészségügyet is). A kapacitások közös használata azonban csak elvétve tapasztalható, mely elsősorban a nyelvi akadályok és a szolgáltató intézmények közötti alacsony fokú együttmüködés következménye.

Összességében elmondható, hogy a magyar-román határtérség számos területen kínál lehetőséget az integrált fejlesztéshez, de ehhez meg kell teremteni az együttmüködés kulcsfeltételeit, és ösztönözni kell a térség szereplői közötti együttmüködések kezdeményezését is.

\subsection{Határ menti index és kutatási eredmények}

Annak érdekében, hogy a határ menti együttmüködés terén javaslatokat és célokat fogalmazzunk meg a szükebb kutatásban résztvevők részére, fontosnak tarjuk megvizsgálni az előző pályázati időszak eredményességét. Céljaink összetettek, hiszen azt szeretnénk, hogy az akciókutatásban résztvevőknek, a civil és önkormányzati szervezeteknek olyan javaslatokat tudjunk megfogalmazni, melyek elősegítik a térség fejlesztését Európai Uniós alapok segítségével a 20142020-as programozási időszakban. Egy másik célunk az, hogy a lezárt pályázatok

eredményességét vizsgáljuk, mivel ezen információk alapján előre láthatóak a következő időszakban rejlő veszélyek, felmérhetőek a problémák, akadályok, amelyekkel a kedvezményezettek szembesültek. Az elkészült indikátor, mint módszer, használható lesz az akciókutatásban résztvevők által is.

A kutatásban és az index elkészítéséhez több adatforrást is felhasználtunk, melyek az alábbiak:

1. Pályázati adatok. Információk, dokumentumok, pályázati leírások, megvalósult elszámolási kérdőívek stb. Ezen információkat a pályázati gazdáktól kaptuk meg. 
2. Intézményi weblapok. Számos pályázatban az eredmények fenntarthatóságát és a partnerek közti kommunikációt többfunkciós weboldal létrehozásával akarták biztosítani a partnerek, tehát e holnapokat néztem meg és az ott fellelhető információkat is felhasználtam.

3. Határ menti kérdőiv. Legfontosabb adatforrás a kutatásban a határ menti intézmények és kedvezményezettek által kitöltött kérdőív.

4. Interjúkészítés. Annak érdekében, hogy a támogató hatóság véleményét is megismerjük, interjúkat készítünk a Budapesti Irányító Hatóság munkatársaival (a magyar-román hatóság munkatársaival).

A „cross border index” egy holisztikus megközelítést alkalmazna a határ menti pályázatok kiértékelésében és az intézményfejlesztésben, ami bármilyen határ menti régió intézményeiben, ahol közös pályázatok valósultak meg, alkalmazható lehet. Ez a következő dimenziókra épül:

1. intézményi és humánerőforrás

2. eredményesség és részvétel

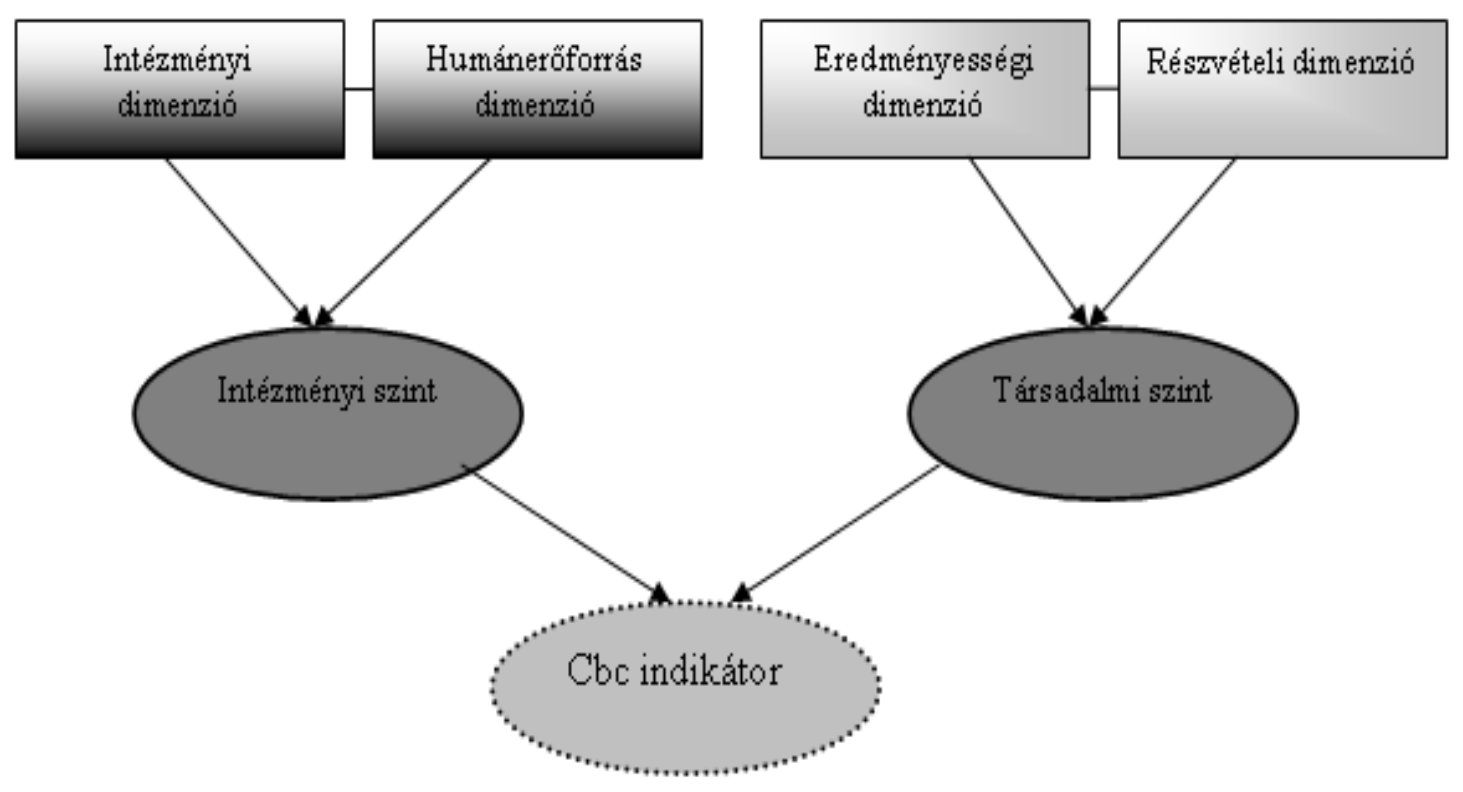

13.ábra: A határ menti (cross border) indikátor módszertana (saját szerkesztés) 
Az első két dimenzió a határ menti szervezetek intézményi teljesítményét jellemzi. E két dimenzióból hozzuk létre a határ menti institutional indikátort, mely azt fejezi ki, hogy a határ menti intézmények mennyit tesznek a sikeres pályázatok érdekében, mit értek el eddig, továbbá méri az intézményi kapacitást is. A másik két dimenzió a határ menti társadalom hozzájárulását mutatja a sikeres intézményfejlesztési projektekben. E két dimenzió eredményéböl jön létre a cross-border indikátor ${ }^{11}$.

Az intézményi és humánerőforrás dimenziók pontjainak számításához kérdőívet készítünk a határ menti intézmények alkalmazottaival. A kérdőív összesen 20 kérdést tartalmaz (10-10 kérdést minden dimenzióhoz). A kérdőív nyitott és zárt kérdésekből tevődik össze. Az eredményességi és részvételi dimenzió számítása a következőképpen történik: az eredményességi dimenziót a pályázati adatlapok és az azokban foglalt tervezett eredmények, és az elért eredmények megfigyelés módszerével számoljuk, míg a részvételi dimenziót egy kérdöív segítségével számoljuk, melyet a projekt kedvezményezettei körében készítünk. A kérdőív összesen 10 kijelentést tartalmaz, melyek Liker-skálaként lesznek feltéve a kedvezményezetteknek.

A célcsoport meghatározásakor a következőket vettem alapul:

1. Határ menti övezetben müködő szervezet

2. PHARE CBC/INTERREG IIIA pályázatot elnyert és lezárt szervezet

3. Önkormányzati vagy nonprofit szervezet

A megkeresett szervezetek PHARE CBC/INTERREG IIIA pályázatok nyertesei, a „people to people” kedvezményezettei. A kutatás első szakaszában megkerestük interneten a 109 nyertes pályázót (70 román és 39 magyar), viszont a visszajelzés

\footnotetext{
${ }^{11}$ A határ menti indikátort a továbbiakban Cbi Indikátor vagy Cross-border Indikátor néven használjuk majd.
} 
alacsony volt. Telefonos megkeresésünkre mindösszesen 49 szervezet (22 magyar és 29 román) vállalta, hogy részt vesz a kutatásban.

A kutatás menete a következő volt: feldolgoztam a magyar-román határ menti övezetben szerzett információkat, és a módszertan tesztelésének érdekében 10 szlovák intézményben alkalmaztuk ugyanezt a módszertant.

A 49 magyar és román szervezetből kiválasztottunk összesen 38 szervezetet (24 románt és 14 magyart). Azért történt több román szervezet kiválasztása, mivel a román részen az alapsokaság 70 nyertes pályázó volt, míg a magyar részen csak 39 intézmény volt, amely ,people-to-people” pályázatot valósított meg. A kiválasztásnál fontos szempont volt, hogy azonos számú önkormányzat és civil szervezet legyen bevonva a kutatásba mind a két oldalról.

A négy összetevő segít abban, hogy a lehetséges mérési hibák vagy a határ menti intézményeknél egyes mutatókban jelen lévő különbségek kiegyenlítsék egymást. Mivel a dimenziók több, egymással nem összemérhető skálájú mutatóból állnak össze, fontos az egyes mutatók súlyozása és standardizálása. Standardizálás alatt a mutatók egyenlő skálára hozását kell érteni, ennek megfelelően:

- Abszolút értéket kapnak azon mutatók, amelyeknél valamilyen általánosan elfogadott alapértékhez lehet viszonyítani.

- Összehasonlító érték használata, más szóval a felmérendő kör átlagos teljesítményéhez történő viszonyítás. Itt nagyjából világos a határvonal és a mérték: minden változónál az átlag feletti teljesítmény a jó, és minél nagyobb az átlagtól való eltérés, annál jobb; ugyanez érvényes az átlag alatti teljesítményekre.

Az intézményfejlesztés méréséhez kifejezetten csak a 2.3 intézményfejlesztést támogató „people-to-people” kis-projektek kedvezményezettjeit céloztuk meg. 
Az intézményfejlesztési pontszám (indikátor) eredménye:

- 30-40 pontszám: az intézményfejlesztés feltételei adottak

- 20-30 pontszám: az intézményfejlesztés komoly akadályokba ütközik, de a feltételek többsége adott az intézményrendszer átalakítására

- 0-20 pontszám: az intézményfejlesztést akadályozó tényezők dominálnak A kutatás helyzete: elkészültek a kérdőívek a magyar és román intézményekben a projektek kedvezményezetteivel. Az Irányító Hatósággal nem sikerült közös nevezőre jutni, többször kértünk időpontot egy közös találkozóra, de mindig elutasításra került kérésünk. Összegezvén, a következő adatok állnak a rendelkezésemre:

\section{A kutatás paraméterei}

\begin{tabular}{|c|c|}
\hline Megnevezés: & Intézményi kérdőív \\
\hline $\begin{array}{l}\text { A kérdezés } \\
\text { időpontjai: }\end{array}$ & $\begin{array}{l}\text { I. hullám (tesztelés a román-magyar határ mentén) } \\
\text { 2008. szeptember 11. - 2009. január } 15 . \\
\text { II. hullám (tesztelés a román-magyar határ mentén a } \\
\text { végleges kérdőívvel) } \\
\text { 2009. szeptember 17. - 2010. május } 12 . \\
\text { III. hullám (végleges lekérdezés a román-magyar határ } \\
\text { mentén) } \\
\text { 2010. október 11. - 2011. január } 7 . \\
\text { IV. hullám (tesztelés a magyar-szlovák határ mentén) } \\
\text { 2011. szeptember 24. - 2011. december } 11 \text {. }\end{array}$ \\
\hline Célcsoport: & $\begin{array}{l}38 \text { intézmény (nyertes pályázók a PHARE CBC/INTERREG } \\
\text { IIIA, People to People komponensében) }\end{array}$ \\
\hline $\begin{array}{l}\text { A kutatásban } \\
\text { részt vevő } \\
\text { szervezetek: }\end{array}$ & $\begin{array}{l}\text { I. hullám: } 6 \text { szervezet ( } 3 \text { román és } 3 \text { magyar) } \\
\text { II. hullám: } 8 \text { szervezet ( } 4 \text { román és } 4 \text { magyar) } \\
\text { III. hullám: } 38 \text { szervezet ( } 24 \text { román és } 14 \text { magyar) }\end{array}$ \\
\hline
\end{tabular}




\begin{tabular}{|c|c|}
\hline & IV. hullám: 10 szervezet (5 magyar és 5 szlovák) \\
\hline A kutatás módja: & $\begin{array}{l}\text { Személyes párbeszéd az alanyokkal (úgynevezett „face to face” } \\
\text { módszer). }\end{array}$ \\
\hline
\end{tabular}

\begin{tabular}{|c|l|}
\hline Megnevezés: & \multicolumn{1}{|c|}{ Célcsoporttal készített kérdőív } \\
\hline & $\begin{array}{l}\text { I. hullám (kérdő́v lekérdezés a román-magyar határ } \\
\text { mentén) } \\
\text { A kérdezés } \\
\text { időpontjai: } \\
\text { II. hullám (tesztelés a magyar-szlovák határ mentén) } \\
\text { 2011. szeptember 24. - 2011. december 11. }\end{array}$ \\
\hline Célcsoport: & $\begin{array}{l}\text { Minden pályázatból megkérdeztünk 5 személyt a közvetlen } \\
\text { célcsoportból. A pályázatok résztvevői közé általánosságban } \\
\text { kb. 15-30 személy tartozott. }\end{array}$ \\
\hline $\begin{array}{c}\text { A kutatásban } \\
\text { részt vevő } \\
\text { szervezetek: }\end{array}$ & $\begin{array}{l}\text { I. hullám: 60 személy } \\
\text { II. hullám: 190 személy }\end{array}$ \\
\hline A kutatás módja: & $\begin{array}{l}\text { Személyes párbeszéd az alanyokkal (úgynevezett „face to } \\
\text { face” módszer). }\end{array}$ \\
\hline
\end{tabular}




\begin{tabular}{|c|c|c|c|c|c|}
\hline Románia & $\begin{array}{c}\text { Intézményi } \\
\text { dimenzió }\end{array}$ & $\begin{array}{c}\text { HR } \\
\text { dimenzió }\end{array}$ & $\begin{array}{c}\text { Eredményességi } \\
\text { dimenzió }\end{array}$ & $\begin{array}{l}\text { Részvételi } \\
\text { dimenzió }\end{array}$ & Cbi \\
\hline Civil szervezet 1 & 7,5 & 7,5 & 8 & 7 & 30 \\
\hline $\begin{array}{c}\text { Helyi } \\
\text { közintézmény } 1\end{array}$ & 4,3 & 3,1 & 5,9 & 4,8 & 18,1 \\
\hline $\begin{array}{c}\text { Helyi } \\
\text { közintézmény } 2\end{array}$ & 4,9 & 4,1 & 6,1 & 4,0 & 18,9 \\
\hline Civil szervezet 2 & 7,7 & 7,9 & 7,7 & 6,9 & 30,2 \\
\hline $\begin{array}{c}\text { Helyi } \\
\text { közintézmény } 3\end{array}$ & 5,1 & 3,2 & 4,9 & 3,7 & 16,9 \\
\hline $\begin{array}{c}\text { Megyei intézmény } \\
1\end{array}$ & 7,3 & 7,5 & 7,6 & 7,9 & 30,3 \\
\hline $\begin{array}{c}\text { Helyi } \\
\text { közintézmény } 4\end{array}$ & 5,2 & 3,2 & 4,9 & 3,9 & 17,2 \\
\hline Civil szervezet 3 & 6,0 & 6,2 & 6,2 & 6,5 & 24,9 \\
\hline $\begin{array}{c}\text { Helyi } \\
\text { közintézmény } 5\end{array}$ & 4,5 & 4 & 5 & 3,5 & 17 \\
\hline Civil szervezet 5 & 6,5 & 6 & 7 & 6 & 25,5 \\
\hline $\begin{array}{c}\text { Megyei intézmény } \\
2\end{array}$ & 7,2 & 7 & 6,9 & 7 & 28,1 \\
\hline $\begin{array}{c}\text { Helyi } \\
\text { közintézmény } 6\end{array}$ & 4,8 & 5,1 & 4,9 & 4 & 18,8 \\
\hline Civil szervezet 6 & 6,1 & 6,4 & 7,5 & 6 & 26 \\
\hline $\begin{array}{c}\text { Helyi } \\
\text { közintézmény } 7\end{array}$ & 6,3 & 5,2 & 6,6 & 6,3 & 24,4 \\
\hline $\begin{array}{c}\text { Helyi } \\
\text { közintézmény } 8\end{array}$ & 5,4 & 4,6 & 4,7 & 4,9 & 19,8 \\
\hline Civil szervezet 7 & 7,1 & 7,4 & 7,5 & 7,3 & 29,3 \\
\hline
\end{tabular}




\begin{tabular}{|c|c|c|c|c|c|}
\hline $\begin{array}{c}\text { Helyi } \\
\text { közintézmény } 9\end{array}$ & 5,6 & 7 & 7,1 & 6,5 & 26,2 \\
\hline $\begin{array}{c}\text { Megyei intézmény } \\
3\end{array}$ & 8,8 & 7,7 & 8,2 & 8 & 32,7 \\
\hline $\begin{array}{c}\text { Helyi } \\
\text { közintézmény } 10\end{array}$ & 6,3 & 6,8 & 5,9 & 6,2 & 25,2 \\
\hline $\begin{array}{c}\text { Megyei intézmény } \\
4\end{array}$ & 7,5 & 7,8 & 7,9 & 7,2 & 30,4 \\
\hline Civil szervezet 8 & 7 & 6,8 & 7,2 & 6,7 & 27,7 \\
\hline $\begin{array}{c}\text { Megyei intézmény } \\
5\end{array}$ & 7,2 & 7,4 & 6 & 7,8 & 28,4 \\
\hline Civil szervezet 9 & 5,2 & 5,6 & 6,1 & 5,9 & 22,8 \\
\hline Civil szervezet 10 & 6 & 7,1 & 6,9 & 7,2 & 27,2 \\
\hline \multicolumn{5}{|c|}{ Átlageredmény - román kutatás: } & 23,63 \\
\hline
\end{tabular}

6. táblázat: A román szervezetek indikátor száma (saját számítás)

A romániai intézményfejlesztési átlageredmény kielégítőnek mondható, viszont az intézményfejlesztés komoly akadályokba ütközik, de a feltételek többsége adott az intézményrendszer átalakítására. Nagy különbség észlelhető a romániai civil szervezetek és önkormányzatok pontszámai között. Egy másik érdekes eltérés, hogy a vidéki, kis önkormányzatok pontszáma a legalacsonyabb. Tehát ezen intézmények szembesültek a legtöbb problémával a pályázatok megvalósításakor és az elszámolások, dokumentumok elkészítésekor. 


\begin{tabular}{|c|c|c|c|c|c|}
\hline Magyarország & $\begin{array}{l}\text { Intézményi } \\
\text { dimenzió }\end{array}$ & $\begin{array}{c}\text { HR } \\
\text { dimenzió }\end{array}$ & $\begin{array}{c}\text { Eredményességi } \\
\text { dimenzió }\end{array}$ & $\begin{array}{l}\text { Részvételi } \\
\text { dimenzió }\end{array}$ & Cbi \\
\hline $\begin{array}{c}\text { Megyei } \\
\text { közintézmény } 1\end{array}$ & 7,5 & 8 & 7,5 & 8 & 31 \\
\hline $\begin{array}{c}\text { Helyi } \\
\text { közintézmény } 2\end{array}$ & 7 & 6 & 7 & 7,5 & 27,5 \\
\hline $\begin{array}{c}\text { Helyi } \\
\text { közintézmény } 3\end{array}$ & 5,5 & 5 & 5 & 5,5 & 21 \\
\hline Civil szervezet 1 & 6 & 7 & 7 & 8 & 28 \\
\hline Civil szervezet 2 & 5 & 7 & 7 & 8 & 27 \\
\hline Civil szervezet 3 & 5,5 & 7 & 7 & 6 & 25,5 \\
\hline $\begin{array}{c}\text { Megyei intézmény } \\
1\end{array}$ & 8,5 & 8,1 & 7,9 & 8,2 & 32,7 \\
\hline $\begin{array}{c}\text { Helyi } \\
\text { közintézmény } 4\end{array}$ & 5,3 & 6,6 & 6,1 & 6,3 & 24,3 \\
\hline Civil szervezet 4 & 5,5 & 7,2 & 7,3 & 6 & 26 \\
\hline Civil szervezet 5 & 5 & 7,3 & 7 & 6 & 25,3 \\
\hline $\begin{array}{c}\text { Helyi } \\
\text { közintézmény } 5\end{array}$ & 4,9 & 6 & 7,1 & 6,1 & 23,1 \\
\hline Civil szervezet 6 & 6,5 & 7,2 & 7,1 & 6,1 & 27 \\
\hline $\begin{array}{c}\text { Helyi } \\
\text { közintézmény } 6\end{array}$ & 4,9 & 6,1 & 6,4 & 6,8 & 24,2 \\
\hline $\begin{array}{c}\text { Megyei intézmény } \\
2\end{array}$ & 8,3 & 8,2 & 8,1 & 7,2 & 31,8 \\
\hline \multicolumn{5}{|c|}{ geredmény - $\mathrm{m}$} & 26,74 \\
\hline
\end{tabular}

7. táblázat: A magyar szervezetek indikátor száma (saját számítás) 
A következő eredmények születtek az indikátor elkészítése után:

- az intézmények közül Románia határ menti térségében két intézmény ért el 30-40 közötti intézményfejlesztési pontszámot. Olyan szervezetekröl van szó, amelyek már évek óta tevékenykednek és van projektmenedzsment tapasztalatuk. Az elért eredmények fényében elmondható, hogy az intézményfejlesztés feltételei adottak, és az elnyert PHARE CBC pályázatok valós eredményeket generáltak.

- a 20-30 intézményfejlesztési pontszámot elért intézmények vidéki önkormányzatok és vidéki civil szervezetek. Itt felmerül a kérdés, hogy miért voltak eredményesebbek az NGO-k pályázatai, mint a közigazgatási intézmények pályázatai? Véleményünk szerint ennek két fö oka van: a romániai önkormányzati alkalmazottak fizetése alacsony, így az önkormányzati projektmenedzsment állások nem vonzóak. Egy másik kiváltó oka az önkormányzati pályázatok sikertelenségének a szakemberek hiánya.

- A magyarországi intézmények többsége 30 pont fölött vagy közel a 30 ponthoz teljesített.

A fenti jellegzetességek megtalálhatók a magyarországi intézményfejlesztési változók elemzése során. Ami viszont kézzelfogható, hogy a magyar intézményfejlesztési átlageredmény magasabb, mint a román. Az eltérésnek több kiváltó oka is volt, melyek közül párat felelevenítünk.

A magyar intézmények már pályáztak PHARE-támogatásra, ezáltal a 2004 után pályázható INTERREG IIIA támogatás igényléséhez felkészülten, a hatályba ültetési folyamatokat ismerve fogtak hozzá, míg Romániában új jellegü támogatásként szembesültek vele. Mindemellett a magyarországi támogató 
intézmények is rendelkeztek elegendő tapasztalattal, ami nem mondható el Romániáról, ahol a nagyváradi székhelyü BRECO-irodát csak 2004 végén hozták létre.

Egy másik érdekessége az eddigi kísérleti jellegü kutatási eredményeinknek, hogy mindkét országban az intézményfejlesztési pontszám magasabb arányt mutat a civil szférában, mint a közigazgatásiban.

Az előző programidőszak pályázatainak elemzése sok új információt nyújtott a jelenlegi kutatási fázisig. Javaslatokat fogalmazunk meg, melyeket már az új Területi Együttmüködési Programban is ajánlunk figyelembe venni:

- A programhatóságnak sokkal aktívabban kell részt vennie a partnerkeresésben, a potenciális érdeklődők segítésében a partnerkeresés során, és a pályázati ötlet véglegesítésekor. Célszerü lenne javaslatokat tenni a pályázati kiírás módosítására annak érdekében, hogy a pályázat valós, határon átnyúló eredményeket érjen el.

- A pályázati időszakban megrendezett szakmai napok jók, viszont sokkal több esettanulmány bemutatása hasznosabb lenne a kedvezményezetteknek.

- Megyei szinten túl kevés az olyan állandó hatósági szakértők jelenléte, akik információt szolgáltathatnának a helyi kedvezményezetteknek. A hatóság jelenleg Budapesten müködik, túl messze a határ menti övezettől, és minden megyében csak egy képviselő van, aki viszont nincs felhatalmazva teljes körü információszolgáltatásra (sok megvalósításhoz kapcsolódó kérdésben csak a budapesti hatóság illetékes).

- A program támogatási alapja jelenleg a teljes határ menti övezetre vonatkozik. 


\section{5.fejezet: VÉGKÖVETKEZTETÉSEK}

PhD dolgozatomban azt tüztem ki célul, hogy a határ menti együttmüködés lehetőségeit és korlátait tárjam fel, egy átfogó kutatási dolgozat formájában az intézményi kapacitás “szemüvegén” keresztül, elkészítve egy akciókutatást a szük kutatási térben.

PhD dolgozatom egyik célja, hogy megvizsgáljam, hogy melyek azok a területek és problémák, ahol a kezdeményezők (köztük akciókutatóként jómagam is) megoldást tudnak találni saját problémáikra saját eszközökkel, akár az állami szervek beavatkozása nélkül is.

A dolgozat ezen utolsó fejezetében bemutatjuk, hogy a civil klaszter és a közigazgatási intézmények képviselöi milyen együttmüködési területeket említettek meg. Minden javasolt témakörhöz javaslatokat fogalmaztunk meg, és leírtam, hogy véleményem szerint milyen fejlesztéseket lehetne a térségben megvalósítani.

A dolgozat első kutatási kérdése az volt, hogy a magyar-román határ mentén számos gazdasági és fejlödési lehetőség van, viszont a társadalmi tőke mértéke alacsony, így a határ mentén lévö területek nem fejlödnek melynek feltételezzük, hogy fö oka, hogy alacsony a társadalmi tőke. Feltételezhető, hogy a társadalmi töke növelésével, a civil társadalom megerösödésével új fejlesztési irányokat kaphatna a térség egyes hálózatok, klaszterek kialakitása révén.

Végkövetkeztetésként elmondható, hogy a civil szervezetek száma magas a térségben, viszont ez nem feltétlenül jelenti azt, hogy e civil szervezetek hozzá tudnak járulni a társadalmi tőke növeléséhez. Számos civil szervezet nem folytat 
valós tevékenységet és bejegyzésük óta nem bonyolítottak programokat, továbbá nincs alkalmazottjuk és nem rendelkeznek irodával, valamint megfelelő pénzügyi háttérrel. Elmondható viszont, hogy a vizsgált településeken vannak aktív és tapasztalt civil szervezetek is.

Elemezve a kérdöív eredményeit az is kiderült, hogy az intézmények többsége csak akkor került a partnerszervezettel kapcsolatba, amikor elkezdték kidolgozni a pályázati adatlapot, tehát a partner intézménnyel mindösszesen pár hónapja dolgoztak együtt vagy a „Az együttmüködést kizárólag a megvalósult projekt idejére lehet lehatárolni” változót választották a kérdőív által nyújtott lehetőségek közül.

A legtöbb válaszadó azt nyilatkozta, hogy „Jelenleg is tarjuk a kapcsolatot, de nem pályázunk közösen”, ami azt igazolja, hogy a pályázat eredményeit nem folytatták egy másik pályázat elkészítésével, viszont érdekes, hogy a válaszadók nem választottak a „Volt kb. 4-8 munkatalálkozónk” vagy „Volt több munkatalálkozónk (kérem számosítsa):...”. A legtöbb válaszadó tehát az általános verziót választotta, mégpedig azt, hogy kapcsolatban van a partnerrel, de nem pályáznak. Egy másik érdekesség, mely a célcsoporttal készített kérdőívből kiderült, hogy a megkérdezettek többsége nem tudta megmondani, hogy mi a partnerszervezet neve. Tehát azok a személyek, akik konkrétan részt vettek a tevékenységekben, nem tudták, hogy melyik volt a határ másik oldalán az az intézmény, akivel közösen valósítottak meg pályázatot.

A kutatás második hipotézise, hogy a közintézmények, civilek befolyásolják vagy sem a társadalmi kapcsolatháló kialakitását, és hogy a pályázatokban „mesterségesen” vagy természetesen alakultak-e ki a kapcsolatok, valamint hogy ezen kapcsolatok „konjunktúrafüggők”-e és csupán a pályázati források elnyerésére jöttek-e létre, vagy hosszú távú partnerségek alakultak ki? 
A fenti hipotézis továbbgondolása nyomán feltételezhető $(H 2 / a)$, hogy az együttmüködésekben részt vevő szervezetek tematikusan és tipizáltan alakultak ki, tehát a partnerségek müködési feltételei adottak voltak. Vagyis az intézmények úgy próbálták kialakítani partnerségi kapcsolataikat, hogy azonos jellegü és tevékenységi körrel rendelkező szervezetet kerestek. Erre a kérdésre úgy próbáltunk választ találni, hogy a pályázati adatlapokat elemeztük. Megnéztük a pályázati kérelmeken a partnerségről szóló részt, és kiderült, hogy a szervezetek többsége azonos jellegü intézmény volt. Ez azt jelenti, hogy az önkormányzatok főként önkormányzatokkal pályáztak, míg a civil szervezetek föként civil szervezetekkel léptek kapcsolatba. Volt viszont néhány pályázat, ahol civil szervezet és önkormányzat, vagy kistérségi társulás és civil szervezet pályázott közösen, és az érdekesség az, hogy két vizsgált projekt, amelyeket nem azonos jogi formával rendelkező szervezetek valósítottak meg, igazán magas cross-border indikátor számot értek el.

Megvizsgáltam a szervezetek honlapjait és az derült ki, hogy nem csak azonos intézményi formák pályáztak közösen, hanem a szervezetek méretét és kapacitásait is figyelembe vették számos partnerségnél. Például, önkormányzatok partnerségénél tipikusnak mondható az azonos méretü települések együttműködése (tehát a községek föként községekkel pályáztak, a kisvárosok hasonló méretü kisvárosokkal, míg a megyei jogú városok, melyek testvértelepülési kapcsolatokban voltak már évek óta, közösen pályáztak).

A civil szervezeteknél megvizsgálván az adatlapokat kiderült, hogy a szervezetek a partner keresésekor föként a tevékenységi kört vették alapul. Tehát az ifjúsági pályázatok partnerei az ifjúság terén aktív civil szervezetek, vagy a vidékfejlesztési pályázatok kérelmezői olyan civil partnerek a határ két oldaláról, melyek vidékfejlesztéssel foglalkoznak.

A dolgozat egyik általunk támogatott eredménye és a saját véleményem is az, hogy az intézményfejlesztés fontos szerepet játszik az európai határ menti 
együttmüködésekben (international development cooperation), tehát elmondható, hogy azon szervezetek, amelyek PHARE CBC/INTERREG pályázatot ültettek életbe, intézményfejlesztést valósítottak meg. Ez nem volt kutatási kérdésünk, viszont részben elemzés nélkül a kérdöívböl kiderült, hogy csak a nagyobb szervezetek, civil és megyei önkormányzatok, vagy nagyobb városok azok, amelyek valós intézményfejlesztést valósítottak meg ${ }^{12}$. Több érdekes kérdést lehet feltenni, hiszen különbségeket véltünk felfedezni a civil szervezetek és az önkormányzatok intézményfejlesztési pontszámai között, míg a vidéki önkormányzatok intézményfejlesztési pontszáma a legalacsonyabb.

Egy másik megállapítás a kutatás végén, hogy a pályázatok lezárása után az elkezdett intézményfejlesztési tevékenységek nem azonos mértékben lettek fenntartva vagy fenntarthatóak a kedvezményezettek által. Ennek a kijelentésnek az igazolására a kérdőív adataira tudunk támaszkodni, illetve a helyszíni megfigyelés módszerét és az adatlapok elemzését is használhatjuk.

A pályázati adatlapokból kiderült, hogy milyen vállalások voltak, hiszen minden szervezetnek le kellett írnia a pályázati kérelembe, hogy milyen eredményeket szeretne elérni és hogyan fogja ezeket az eredményeket fenntartani a pályázat lezárása után. A kérdőív elemzéséből kiderült, hogy a pályázatban alkalmazott szakértők többsége új, létrehozott pozíció, melyek csak a pályázati támogatás idejében léteztek, tehát a szervezetek nem tudták finanszírozni a személyi költségeket. A kérdésre, hogy „Az elért eredmények jelenlegi fenntartása milyen jellegü erőforrásokat igényel?, a pályázók többsége főként a „humánerőforrás” változót választotta. Tehát a jelenlegi alkalmazottak azok, akik folytatják a pályázat eredményeinek fenntartását. Érdekes, hogy a megkérdezett szervezetek közül egyik szervezet sem választotta azt a lehetőséget, hogy

\footnotetext{
${ }^{12}$ Az intézményfejlesztési pontszám, a Cbi alapján tesszük ezt a kijelentést.
} 
„egyszeri” vagy „rendszeres pénzügyi forrás”. Megvizsgálván a pályázati adatlapokat kiderült, hogy a projektek jellegéből adódóan a pályázók főként olyan eredmények fenntartására vállalkoztak, mint például közös honlap, szakértői hálózat, ifjúsági hálózat és gazdasági partnerségek.

A helyi megfigyelés eredményeként elmondhatom, hogy számos helyzetben a hálózatok nem müködnek, és a jelenlegi alkalmazottak nem igazán tudták, miről is van szó. Viszont pozitív példákat is találtunk jól müködő ifjúsági online háló és más hasznos weboldalak formájában.

A kutatás harmadik kérdése az volt, hogy a 2004-2006 idöszakban a megvalósult, sikeresnek mondott pályázatok fokozzák az érdeklödést, és hogy a 2007-2013 időszakban megvalósult pályázatok száma nött, sốt egy idöben a pályázatok számának emelkedésével növekedett a versengés, és ezáltal a pályázatok minősége is. Ezen kijelentés arra mutat rá, hogy a térségben számos olyan intézmény van, mely képes lesz a 2014-2020-as programozási időszakban megvalósítani olyan integrált, határon átnyúló pályázatokat, melyek a térség fejlödését segítik elö.

Végkövetkeztetésként fontos elemezni azt is, hogy a partnerek saját költségvetésből vagy újabb pályázatok elnyerésével törekedtek-e fenntartani az elért eredményeket, netalántán volt-e kezdeményezés az elkezdett közös fejlesztések folytatására. Fontos szempont tehát, hogy egy intézményfejlesztést meg lehet-e valósítani külső kényszer vagy külső pénzügyi támogatás nélkül. A kérdés az, hogy az olyan önkormányzatok, amelyek nem részesültek EU-s támogatásokban, valósítottak-e meg határon átnyúló intézményfejlesztési tevékenységet, vagy képesek-e jövőbeli fejlesztések megvalósítására? A választ a kérdőív és a nyertes pályázók listáinak elemzéséből kapjuk meg. Az eredmények fenntartása föként források bevonása nélkül valósult meg, vagy ha szükséges volt, 
akkor minimális költségek voltak (weboldalak fenntartása, találkozók stb.). A kérdésre, hogy az önkormányzatok, melyek nem részesültek Európai Uniós támogatásban, valósítottak-e meg határon átnyúló intézményfejlesztési tevékenységet úgy kerestük a választ, hogy az önkormányzatokat - melyeket bevontunk a kutatásba - arról kérdeztük, hogy milyen tevékenységeket valósítottak meg a határon átnyúló testvértelepülésükkel. Az esetek többségében a települések csak egy határon túli partnerrel rendelkeznek, mégpedig azzal, amellyel a román-magyar pályázatot valósították meg. Azon szervezetek, melyek több partnerrel rendelkeznek elmondták, hogy az együttmüködés föként a saját fesztiválokra, falunapokra, rendezvényekre való közös meghívásra/részvételre fókuszál. Végkövetkeztetésként tehát elmondható, hogy ez a hipotézis nem igazolódott be, hiszen az olyan szervezetek, melyek nem kaptak Európai Uniós támogatást, nem kezdeményeztek és valósítottak meg intézményfejlesztési tevékenységeket. Ennek okait nem vizsgáltuk, hiszen nem ez volt a dolgozat fö témája, viszont érdemesnek tartom arra, hogy egy jövőbeli kutatásban rávilágítsak a testvér-települési kapcsolatokban rejlö és még ki nem aknázott lehetőségekre.

A kutatás eredményeként elmondható, hogy a PHARE CBC/INTERREG IIIA program nem valósult meg minden esetben gördülékenyen, hiszen a megvalósítás csak részben volt sikeres. A nagyobb civil és önkormányzati szervezetek által elért Cbi indikátor szám azt igazolja, hogy a pályázatok megvalósítása gördülékenyen zajlott.

A harmadik kutatási kérdés (H3) alapgondolata, hogy a pályázatok és a határ menti együttmüködés folytonosságának biztosítása érdekében feltételeztük, hogy a megvalósult, sikeresnek mondott pályázatok fokozták az érdeklödést. Tehát az ideális alapelv szerint, ha egy adott évben X számú pályázatot valósítottak meg az 
intézményfejlesztés terén, akkor a következő évi pályázati kiírásban a pályázatot benyújtó intézmények száma magasabb kellene legyen, mint az előző évi pályázók száma. A választ erre a kérdésre a beadott pályázati listák elemzésével kerestük. Kiderült, hogy a pályázatok száma növekedett az új Területi Együttmüködési Programban, viszont a „people to people” pályázatoknál nem mondható el, hogy az érdeklődés növekedett volna. Ha a 2004-es, 2005-ös és 2006-os években beadott pályázatok számát nézzük, akkor megállapítható, hogy stagnáló, kisebb eltérések jellemzőek a beadott pályázatok számában, tehát a PHARE CBC/INTERREG IIIA projektek eredményei és népszerüsítése nem feltétlenül késztette nagy számban a szervezeteket pályázatok beadására. Viszont ha behatóbban nézzük a pályázók listáit, akkor elmondható, hogy ha nem is növekedett feltétlenül nagymértékben a pályázók száma, de évről évre új pályázók is megtalálhatóak a listákon, tehát az érdeklődés mégis csak jelen volt a határ menti intézményekben.

Egy másik kérdés, hogy évröl évre csak a pályázatok száma nő-e, vagy ha növekedés mutatkozik, azzal párhuzamosan a pályázatok minősége is évről évre javul-e. Erre a kérdésre jelenleg a rendelkezésünkre álló adatlapok elemzésével tudunk csak választ adni, hiszen a hatóság alkalmazottaival még nem sikerült felvenni a kapcsolatot.

Az adatlapokból az derül ki, hogy azon pályázók, akik évről évre adtak be pályázatokat, egyre jobb és komolyabb szakmai anyagokat nyújtottak be, viszont vannak olyan pályázók is, akik csak egy pályázatot nyújtottak be, és érdekes módon az minőségi pályázat volt. Fontos megjegyezni, hogy a 2007-2013-as időszakban megváltozott a pályázati adatlap formája és sokkal egyszerübb lett. Amíg a régi PHARE CBC/INTERREG IIIA rendszerben lehetőség volt például a tevékenységek, motiváció részletes leírására, addig a jelenlegi rendszer strukturáltabb, valamint minden kategóriához megkötés van, hogy mennyi a maximum karakterszám, ami leírható. 
Egy másik megállapítása a dolgozatnak, hogy a 2014-2020-as időszakban új intézményi formát kell alkalmazni annak érdekében, hogy a hatásosság és az eredményesség növekedjen. A kisebb vidéki önkormányzatok és a kisebb civil szervezetek már a 2007-2013-as idöszakban sem voltak képesek felvenni a harcot a nagyvárosokkal és a nagyobb szakmai civil szervezetekkel, ezért várható, hogy a 2014-2020-as programozási időszakban újból szembesülni fogunk ezzel a problémával.

Véleményem szerint az új programozási időszakra úgy kell a helyi szervezeteknek felkészülni, hogy olyan nagyobb intézményeket hoznak létre, amelyek képesek úgy megjelenni, hogy egy adott térség vagy egy tágabb célcsoport érdekeit képviselik pályázatukkal, és ezáltal versenyképesek lesznek a nagyvárosokkal, illetve a nagy szakmai civil szervezetekkel.

Véleményem szerint az EGTC az egyetlen olyan intézményi jogi forma, mely a müködő partnerségeket igazolja, sőt hosszú távon elmondható, hogy az EGTC-k képesek lennének olyan stratégiák megalkotására, melyek egy nagyobb határ menti területet fednek le és valós, meglévő helyi problémákat vázolnak, amelyek határ menti együttmüködések segítségével közösen megoldhatóak. A helyi önkormányzatok képviselőinek tehát egy EGTC létrehozását javasoltuk, míg a civil szervezetek képviselőinek egy Civil Klaszter alapítását. 


\subsection{Az akciókutatás eredményei}

Akciókutatásunk eredményeként a szük kutatási térben két intézmény alakult meg: egy EGTC ${ }^{13}$ és egy Civil Klaszter.

\section{Az Európa-kapu Korlátolt Felelősségü Európai Területi Együttmüködési}

Csoportosulás alapító önkormányzatai Magyarországról Nyíradony, Derecske, Hajdúhadház és Újfehértó, Romániából pedig Székelyhíd, Érmihályfalva, Kiskereki és Nagykároly.

Az ETT területén számos gazdasági és turisztikai lehetőség adódik. Az ETT célja, hogy ezekre az erőforrásokra alapozva a partner önkormányzatokkal, a térségi civil szervezetekkel és a magáncégekkel közösen olyan fejlesztési programokat határozzon meg, amelyek a térség teljes gazdasági és szociális fellendülését biztosítják.

Az Európa-kapu ETT ${ }^{14}$ egy új intézményi eszköznek tekinthető, melynek székhelye Nyíradonyban van, viszont tagjai román és magyar önkormányzatok. Az ETT egyik fö előnye, hogy a területi együttmüködési pályázatokban (például a Magyar-Román Területi Együttműködési Program) a partnerség elvét nem kell a támogató felé igazolni, hiszen a szervezet alapból teljesíti az ilyen feltételeket. Ezen előny eredménye, hogy a létrehozott közös intézmény nagyobb sikerrel pályázhat a határon átnyúló Európai Uniós finanszírozású pályázatokra.Az EGTC Rendelet ${ }^{15}$ megteremti azt az új, innovatív jogi keretet, mely lehetőség nyújtott az akciókutatás eredményeként létrehozott intézmény megalakítására. A

13 EGTC: European Grouping of Territorial Cooperation (Európai Területi Együttmüködési Csoportosulás). A magyar törvényi szövegkörnyezetben az ETT is használatos, a rövidítés jelentése Európai Területi Társulás. A jelen dokumentum további részeiben az ETT (Európai Területi Társulás) rövidítést használjuk.

${ }^{14}$ Az EGTC bejegyzéséről szóló végzést a budapesti Fővárosi Törvényszék 2012. május 4-én adta ki.

15 AZ EURÓPAI PARLAMENT ÉS A TANÁCS 1082/2006/EK RENDELETE (2006. július 5.) az európai területi együttmúködési csoportosulásról 
Rendeletnek köszönhetően egy olyan intézmény jött létre a szük kutatási térben, mely a két állam - Magyarország és Románia - jóváhagyásával rendelkezik, viszont jogi személyiségét Európai Uniós intézménytől, mégpedig a Régiók Bizottságától kapta.

Egy másik létrehozott intézményi forma a Civil Klaszter, a térségi civil együttmüködési forma, mely a térségben aktív civil szervezeteket tömöríti magában. A Civil Klaszter szakmai munkáját az Európa-kapu ETT munkatársai és a térségi civil szervezetek munkatársai irányítják és segítik. A térségben egyre több a rendezvény és a kezdeményezés, melyek a civil klaszter eredményeként valósultak meg. Az eddig elért egyik legnagyobb eredmény, hogy sikerült több, a Nemzeti Együttmüködési Alap Nemzeti Összetartozás Kollégiuma által támogatott pályázatot nyerni.

A Nemzeti Együttmüködési Alap Nemzeti Összetartozás Kollégiuma olyan pályázatokat is támogat, amelyek kedvezményezettei a határon átnyúló szervezetek. A Civil Klaszter lehetőséget adott arra, hogy romániai és magyarországi civil szervezetek találkozzanak és támogatta közös partnerségek létrehozását is. Ezáltal létrejöttek olyan civil szervezetek közötti kapcsolatok, melyek 3 és 5 millió forint közötti támogatást kaptak. Az egyik ilyen pályázat egy Kárpát-medencei Konferencia, melynek célja egy olyan partnerség kialakítása, amely később a Duna Stratégiából részesülhetne. 


\subsection{SWOT elemzés}

Annak érdekében, hogy a szük kutatási térségre jellemző erősségeket, gyengeségeket, lehetőségeket és veszélyeket bemutassuk, elkészítünk egy SWOT elemzést.

\section{Erősségek}

A térség egyik legnagyobb előnye földrajzi elhelyezkedésében rejlik. Mind a román, mind a magyar terület határai a térség legjelentősebb városai: Szatmárnémeti, Nagyvárad és Zilah Romániában, valamint Nyíregyháza és Debrecen Magyarországon. A nagyvárosi funkciók és lehetőségek számos új előnyhöz juttatják a térséget, ugyanis a szolgáltatások elérési árai sokkal magasabbak a nagyvárosokban, mint az Európa-kapu ETT területén elérhető szolgáltatásoké.

Egy másik fontos szempont, hogy egyre többen látnak lehetőséget a nagyvárosokon kívül rendelkezésre álló szolgáltatások igénybevételére, például konferenciaszervezés, faluturizmus, aktív kikapcsolódás és pihenés területén. Egy másik fontos előnye a területnek - mely voltaképpen abból fakad, hogy a települések ETT-be tömörültek -, a határon átnyúló, több éve fennálló kapcsolatok és együttmüködések. Ezek az együttmüködések főként a kulturális, a közösségi és az intézményi kapcsolatokra jellemzőek, és ezekre az együttmüködésekre építeni lehet új és nagyobb közös programokat, gazdasági területen is.

A megyeszékhelyek közelsége (Debrecen, Nyíregyháza, Szatmárnémeti, Nagyvárad) a térség gazdasági életében betöltött központi szerepük következtében az ETT számára több szempontból is előnyös. Az ETT területének elszigeteltsége ezáltal enyhül, hiszen Debrecenből, Nyíregyházáról, 
Szatmárnémetiböl, valamint Nagyváradról elérhetőek az ETT települései vasúton vagy busszal.

A térségben számos helyi termék fellelhető. A mezőgazdasági termelők száma nagy, viszont sok helyen jellemző a mezőgazdasági területek elaprózódása (kis területeket művelnek meg, ennek következtében nem létezik egységes és nagy mennyiségben rendelkezésre álló termékkínálat a megtermelt zöldségekböl, gabonafélékből és gyümölcsökből). Minden településen jelen vannak az úgynevezett nagytermelők is. A térségben jelentős a gyümölcs-, a kukorica-, a gabona-, valamint a zöldségtermesztés.

A térség másik erőssége a jó minőségü legelők megléte, melyek a román területen föként az önkormányzatok tulajdonában vannak. Erre az erősségre alapozva lehetne újra feleleveníteni a szarvasmarha tenyésztést, melyre építeni lehetne egy feldolgozó üzemet is. Ezáltal a térségben előállításra kerülhetne egy olyan egyedi termék, amelyet nem csak a nemzeti, hanem a nemzetközi piacokon is lehetne népszerüsíteni és értékesíteni.

A szarvasmarha és a vadhús feldolgozása ugyanazon a helyen is történhetne, és ezek a hústermékek megjeleníthetőek lennének a nemzeti és a nemzetközi piacokon egyaránt, mint a térségben előállított helyi termékek.

A térség további erőssége, hogy a turisták és a látogatók alacsony utazási időráfordítással be tudják járni az ETT területét és számos turisztikai látványosságot, szolgáltatást tudnak igénybe venni.

A térségben elérhetőek termálfürdők (Tasnád és Margitta), népszerüek az érmelléki (Kiskereki, Érmihályfalva, Székelyhíd) és a krasznabélteki borok, és egyes településeken kellemes hangulatú borpince várja a látogatókat, továbbá számos kirándulási, vadászati, túrázási lehetőséget nyújt a Gúthi erdő. A gazdaság fejlesztésének egyik alapja lehet a vadgazdálkodás, hiszen a Gúthi erdő az Alföld egyik legnagyobb összefüggő erdeje. 
A térségben fellelhető látványosságok és erősségek a következők, amelyekre alapozni lehet a turizmus fejlesztését, integrált megközelítésben:

- Nyíradony híres szülötte Harangi Imre olimpiai bajnok ökölvívó, akinek nevét viseli a város újkori szimbóluma, a 2003-ban átadott nemzetközi színvonalú rendezvénycsarnok. Nyíradony nevezetességei közé tartozik a Gúthi Puszta-templom romja, a Római katolikus templom, a Görög katolikus templom, valamint a Református templom.

- Hajdúhadház jelképe a fötéren elhelyezkedő neoromán stílusú, kéttornyú Református templom. Hajdúhadház nevezetességei közé tartozik a Városháza épülete és a Csokonai Művelődési Ház épülete. A város híres szülötte Dr. Földi János hajdúkerületi orvos, polihisztor, valamint Szilágyi Dániel 1848-as huszár.

- Újfehértón is számos látnivaló van, nevezetességei közé tartozik a Görög katolikus templom, a Református templom, valamint a Városi Múzeum. A helyi mủemléki védelem alatt álló, késő barokk Római katolikus templomot 1812-ben szentelték fel.

- Derecskén sok olyan rendezvény van, melyek alapjai lehetnek egy fesztiválokra, rendezvényekre alapozó turizmusnak. Kulturális és hagyományőrző rendezvényei, gazdag sportélete, középiskolája, művészeti iskolája, a közszolgáltatások magas színvonala élhető, fejlődő kisváros képét mutatják, mely rugalmasan alkalmazkodik a XXI. század kihívásaihoz.

- Nagykároly turisztikai szempontból fontos szerepet tölt be az ETT-ben, hiszen itt található az impozáns Károlyi-kastély. A kastély eredetileg a XV. században épült, de mai alakját csak a XIX. század végén kapta, amikor neogótikus stílusban átépítették. A látványossághoz hozzájárul a kastélyt körülövező angolkert is, amely ma is nagyon szép. A kastélyban természettudományi és őstörténeti kiállítás tekinthető meg. Nagykároly 
hangulatos központja, magas fákkal szegélyezett központi utcái megőrizték a letünt idők hangulatát.

- Székelyhíd sík részein mocsaras tavak találhatók: az olaszi és kágyai tavak, valamint a Csíkos-tó, mely természetvédelmi terület. Szőlö- és borkultúrája több évszázados hagyományokkal rendelkezik: Székelyhídon és környékén több, mint 400 borospince található. Székelyhídon termálstrand működik, a termálvíz minősége számos turistát és látogatót vonz a térségbe.

- Kiskereki mindig is mocsaras vidék volt, gazdag hal, vízinövény és madár populációval, azonban a '60-as évek végén az érmelléki mocsarat is lecsapolták, és ennek maradványaként itt található egyedülálló terület a Kárpát-medencei ősmocsár utolsó maradványa. A visszamocsarasítás során megtelepülő növényzet kiváló alapanyagot biztosít a tradicionális kosárfonó mesterség felélesztésére. Korábban - föleg az érkeserüiek kosárfonásból éltek, emellett fontos volt a halászat, a madarászat és a vadászat. Ezek a lehetőségek a turizmus felélénkítésére használhatóak, melynek olyan látványosságok lehetnek az alapjai, mint a Pósa tó partján újra felépítendő híres Betyár Csárda, valamint a Só út és a pincesor történelmét bemutató turisztikai ösvények létrehozása is.

- Érmihályfalván minden évben megrendezésre kerül a Nyíló Akác Fesztivál, mely a térség egyik jellegzetes rendezvényévé vált az elmúlt húsz esztendőben. A Nyíló Akác Néptánccsoport évtizedek óta a térség hagyományait, táncait ápolja és mutatja be nem csak országos, hanem nemzetközi szinten is.

A térségben olyan multikulturális tevékenység ismerhető fel, mely fontos pontja lehet a turizmusnak. Az ETT területén élnek magyar, román, sváb és roma lakosok egyaránt. Ezen lakosok hagyományai és életmódja bemutatásra 
kerülhetne egy román, magyar és angol nyelvü kisfilm segítségével, továbbá erre alapozni lehetne egy térségi múzeum létrehozását is. (Erre mintaként szolgálhatnak az ország más részein található falumúzeumok, viszont az általunk javasolt térségi múzeum jellegzetessége az lenne, hogy nem csak egy tájegység, vidék, hanem több kultúra hagyományait és életvitelét mutatná be a határ mindkét oldaláról származó termékekkel és eszközökkel.)

Az ETT területén megtalálható számos olyan energiaforrás, amely jelenleg még nincs teljesen kihasználva. Itt föként a termálvízre, valamint az erdökben, a biomasszában, a brikettben, valamint a napkollektorokban rejlö lehetőségekre gondolunk. A térségben elég sok helyen zajlik már biobrikett készítés, valamint sok helyen telepítettek energiafüzt.

A termálvíz kihasználása jelenleg Székelyhídon a leghatékonyabb, hiszen ott a közintézmények és a lakások fütésére használják. Egy másik lehetősége a térségnek a kiváló minőségü ivóvíz. A térségben a legjobb minőségű ivóvízzel Kiskereki és Székelyhíd rendelkezik.

\section{Gyengeségek}

A mezőgazdaság területén elmondható, hogy jelentős számú termelő van, viszont kis területeket müvelnek meg. A termelők egyik legnagyobb problémája a tároló helyek, valamint a feldolgozó- és felvásárló egységek hiánya. Emellett vannak olyan tényezők is - mint például az időjárás -, amelyeket nem lehet befolyásolni. A területen elindult a „Mezőgazdasági klaszterként” emlegetett közös kezdeményezés. A partnerség célja olyan határok nélküli, közös együttműködési lehetőségek, eszközök és tevékenységek megvalósítása, amelyek elősegítik a térség mezőgazdaságának fejlődését. 
A térség számos községében, valamint kisebb településén (föként a romániai települések esetében) hiányoznak az alapvető infrastruktúrák (víz, szennyvíz- és csatornarendszer, utak stb.).

A lakosság tudatában nem alakult még ki egy térségi, ETT-s szemlélet. A térségben élő emberek még nincsenek tudatában annak, hogy egy közös, összetartozó területen élnek, melynek fejlesztése a magyar és román önkormányzatok által összefogva, egy közös szervezetben valósítható meg. Ez a gyenge pont felismerhető lehetőségként, hiszen az ETT munkacsoportjának egyik fő feladata az, hogy olyan fejlesztéseket vigyen végbe, melyek ezt a közös összetartozást erősítik a lakosság körében.

\section{Lehetőségek}

A mezőgazdaság egyik legnagyobb problémája az időjárás, főként a nyári időszakra jellemző szárazság. Ha sikerülne létrehozni öntöző rendszereket az ETT területén - kihasználván a helyi földrajzi adottságokat -, akkor a mezőgazdaság a térség húzóereje lehetne. Annak érdekében, hogy a mezőgazdaságban fejlődést érjünk el, fontos megteremteni a közös együttműködést támogató intézményi kereteket is a termelés, a feldolgozás és az értékesítés területén.

A borászat, a borkészítés - mint térségi ETT termék - húzóereje lehet a fejlesztéseknek. Hajdúhadházon például az utóbbi években elkezdődött a szölötelepítés. A térségben - köszönhetően a számos természeti értéknek, valamint a nyugodt, csendes kisvárosi és vidéki környezetnek - fellelhető minden olyan szükséges eszköz, mely elősegíti az egészségturizmus létrejöttét. Ennek a szolgáltatásnak viszont számos infrastruktúrára is szüksége volna, ezért források bevonása javasolt. 
A térségben lehetőség lenne a nagyobb helyi településeket összekötni menetrendszerinti járatokkal. Ennek érdekében érdemes elkészíteni egy tanulmányt, hogy mennyire lenne igény erre a szolgáltatásra. Például szükséges-e összekötni buszjárattal Nagykárolyt, Vállajt és Nyíradonyt vagy Székelyhidat és Nyírábrányt, Debrecenen keresztül Hajdúhadházzal.

Valószínúleg csak a közvetlen határ menti településeket érdemes ilyen tanulmány készítésébe bevonni, viszont az már most is látható, hogy nagy a határforgalom. Leginkább a román részről a magyar részre figyelhető meg az emberek áramlása, melynek céljai között legtöbbször a vásárlás, a termálfürdőzés, a kirándulás és az oktatás szerepel.

A térségben lehetöség volna tematikus utak kialakítására (többek között össze lehetne kötni a turisztikai látványosságokat a határ mindkét oldalán, például borút, kastély, tanösvények összekötése stb.). Ezáltal a térségben egy egyedi, határokon átívelő turisztikai szolgáltatás jönne létre. Erre jó lehetőséget kínál a román határ várható teljes megszünése, hiszen az európai szintéren egyre többet beszélnek arról, hogy a schengeni egyezmény részesévé válik Románia is, teljesítvén minden kritériumot. Ezáltal az Európai Unió határa kitolódik, és a térség még jobban átjárható lesz.

A fiatalok száma a térségben jelentős, viszont elkezdődött egy elvándorlási folyamat, amelyet meg kellene állítani vagy a mértéket kellene csökkenteni. A fiatalok a középiskola elvégzése után a felsőfokú tanulmányaikat a nagyvárosokban kezdik el, és mivel helyi szinten nem találnak munkát, így a nagyvárosokban maradnak és ott folytatják életüket. Ennek érdekében két fő irányban kell az ETT-nek tevékenységeket kezdeményeznie.

Elsősorban fontos egy olyan ifjúsági közösségi életet kialakítani, amely már a kiskortól kezdve foganatosítja a gyerekekben azt a tudatot, hogy szeretnek azon a településen élni, ahol születtek, valamint szeretnek a velük egykorú fiatalok társaságában lenni. Fontos az „itthon lenni jó” életérzés kialakítása és 
népszerüsítése. Ennek elérése érdekében fontos olyan térségi kezdeményezéseket, közös programokat kialakítani (táncház, kórusok, közös táborozás, közös szakkörök stb.), melyek elősegítik a fiatalok szabadidejének megfelelő és tartalmas eltöltését.

A másik fontos irány, amelyet az ETT-nek kezdeményeznie kell, hogy a térségben beinduljon egy aktív gazdasági élet, mely képes a fiataloknak helyben megfelelő munkalehetőséget biztosítani. Ennek érdekében nemcsak a befektetőknek megfelelő térségi gazdasági övezetet kell kialakítani, hanem a helyi szinten meglévő kezdeményezéseket és vállalkozásokat is segíteni és támogatni kell.

Ha a térségben az ETT képes lesz a helyi szereplök (önkormányzatok, civil szervezetek, vállalkozók) bevonásával elkészíteni egy Integrált Területi Beruházási tervet (rövidítve ITB), amely magában foglalja a térséget legnagyobb mértékben érintő problémák megoldását, továbbá ha az ETT képes lesz az ITB megvalósítására Európai Uniós forrásokat szerezni, akkor várhatóan a térségi problémák csökkennek és a határ menti együttmüködés új szintekre helyeződik. Ez a szint alapja lehet a közös, lendületes fejlődésnek.

\section{Veszélyek}

A térségben az ETT-be bevonni kívánt önkormányzatok száma körülbelül hatvan. Ha nem sikerül kialakítani olyan együttmüködést a polgármesterekkel, amely a közös problémák megoldásáról szól, akkor nehéz lesz a közös tevékenységek megvalósítása. A jelenlegi nyolc alapító önkormányzat teljesen jól látja a közös fejlesztési irányt, és minden javaslatot pozitívan fogadnak, továbbá kiváló az együttmüködés a munkacsoport és a Közgyülést alkotó polgármesterek között.

Egy másik veszély az lehet az ETT térségének fejlődésében, ha a nagyvárosok Debrecen és Nagyvárad vagy Nyíregyháza és Szatmárnémeti - olyan jellegü 
kezdeményezésekbe fognak, mint a mi szervezetünk, azaz ETT-t alapítanak, amelybe partnerként bevonják a mi ETT-nkben lévő településeket. Ez egy olyan veszély, amelynek a kockázati szintje alacsony, hiszen ha a nagyvárosok ETT-t alapítanak, akkor valószínüleg csak a fent említett városok lesznek a partnerei a szervezetnek.

Ennek érdekében javasolt, hogy az ETT munkacsoportja nyisson a megyei és nagyvárosi kezdeményezések felé olyan értelemben, hogy a már meglévő fejlesztéseket és a tervezett lépéseket ismertesse közvetlen és közvetett módon egyaránt a megyei és nagyvárosi vezetőkkel (közös találkozók, sajtómegjelenések, lakossági találkozók az ETT településein stb.).

Az ETT fejlödését befolyásolhatják az Európai Unió és a két állam Magyarország és Románia - szintjén elfogadott döntések. Itt föként arra gondolunk, hogy az Európai Területi Együttmüködési Programok tervezésében, valamint a közös Operatív Program elkészítésében a két állam képviselői és a közös munkacsoportok milyen szerepet szánnak az ETT-knek. Ha az Operatív Programban és a megyei fejlesztési stratégiákban is megjelenik az, hogy az ETT fontos eleme és megfelelő eszköze a határon átnyúló együttmüködésnek, akkor várható lesz, hogy a 2014-2020-as programozási időszakban az ETT képes lesz számos területi fejlesztésre.

Mivel magas a romák száma az ETT egyes településein, illetve a nem roma lakosság körében pedig egyre nagyobb a migráció - azaz elvándorlás - a nagyobb és fejlettebb városok felé, emiatt az elkövetkező években komoly demográfiai és szociális problémákkal szembesülhet a térség. Nem az a gond, hogy egyre növekszik a romák száma, hanem a problémát az jelenti, hogy nehezen lehet őket integrálni, továbbá nehézkes az iskolapadban tartani és szakmára tanítani őket. Ezen probléma kezelésében fontos szerep juthat a jövőben a már megalakult civil hálónak - klaszternek -, mely az ETT térségében lévő aktív egyesületeket és alapítványokat foglalja magában. 


\subsection{Fejlesztési irányok és lehetőségek}

Az ETT területén több irányban fontos fejlesztést kezdeményezni. A fejlesztésnek egyik fontos eleme, hogy a munkacsoport ${ }^{16}$ a szervezet Közgyülésével közösen olyan együttmüködést hozzon létre, amelybe képes bevonni a települések lakosságát, magánvállalkozásait és civil szervezeteit.

Amit fontos tisztázni a fejlesztési irányok meghatározása előtt, hogy a fejlesztést nem csupán az ETT-nek kell véghezvinnie, hanem más szervezetek bevonásával is történhet fejlesztés. Ez azért fontos szempont, mert az ETT mint intézmény, nem pályázhat minden forrásra, vagy számos országos forrásnál csak úgy pályázhat, hogy a magyarországi vagy a romániai területen valósíthat meg fejlesztést. Viszont ez nem feltétlenül jelenti azt, hogy az ETT nem képes területi fejlesztést elöirányozni és kezdeményezni, hanem egyszerüen csak azt jelenti, hogy a lentebb javasolt fejlesztési tevékenységek „projekt gazdája” nem minden esetben csak az ETT lehet, hanem más szervezetek is lehetnek a tevékenységek vezetöi.

Javasoljuk, hogy az Európa-kapu ETT fő víziója a 2014-2020 programozási időszakra a következő legyen: ”Az Európa-kapu ETT területén fejlödés kezdödik. Ennek egyik eredménye, hogy csökkennek a szociális problémák, hiszen mérséklödnek a perifériális földrajzi helyzettel, a munkanélküliséggel és az elvándorlással összefüggő gazdasági-társadalmi problémák is. Egy másik eredménye a fejlödésnek, hogy optimalizálódnak a gazdasági-társadalmi viszonyok és kapcsolatok feltételei, továbbá javul az ETT területén élök életminösége és ezáltal az ETT területének népességmegtartó ereje."

${ }^{16}$ Az ETT-nek jelenleg négy alkalmazottja van: ebből 2 főállású és 2 részmunkaidős 
Jelenleg a térségben jellemző a munkanélküliség, a stagnáló gazdaság, továbbá felismerhetőek az ETT-n belül erősödő területi egyenlőtlenségek is,Ezen problémák szükségszerüen alapjai a fenti célok elérésének, hiszen az életminőség további romlását meg kell állítani annak érdekében, hogy a jellemző negatív vándorlási egyenleg megváltozzon, és az ETT területe ne csupán növelje a népességmegtartó erejét, hanem új személyeket és befektetőket is képes legyen a térségbe vonzani.

A népességmegtartó képesség és a területi felzárkózás csak akkor lehet cél, ha az ETT képes növelni a térség versenyképességét és ezzel egy időben a foglalkoztatottak számát is, és egyben a környezettudatos meglátással fenntartható fejlődési pályára lesz képes állítani a gazdasági fejlődést, továbbá ezzel egy időben képesnek kell lennie megszervezni egy társadalmi felzárkóztatási programot is, mely elősegíti a hátrányos helyzetü társadalmi csoportok beilleszkedését.

A létrejött ETT-nek javasoljuk, hogy a következő fejlesztési irányokat célozza meg:

\section{Gazdaságfejlesztés}

2. Társadalmi kohézió erősítése

3. Oktatási infrastruktúra és új módszerek fejlesztése

4. Intézményi együttmüködés a meglévő kapacitások növelése érdekében

A fentebb említett fejlesztési irányokat javasoljuk kidolgozni programokra, beavatkozási területekre és konkrét pályázati adatlapokra, melyek támogatást nyerhetnek egy Integrált Területi Beruházásként az új Területi Együttmüködési Programban a 2014-2020-as időszakban. 


\subsection{Az akciókutatás eredményei - innováció a határ menti térségek fejlesztésében}

Akciókutatásunk eredményeként a szük kutatási térben két intézmény alakult meg: egy EGTC ${ }^{17}$ és egy Civil Klaszter.

\section{$\mathrm{Az}$ Európa-kapu Korlátolt Felelősségü Területi Együttmüködési}

Csoportosulás alapító önkormányzatai Magyarországról Nyíradony, Derecske, Hajdúhadház és Újfehértó, Romániából pedig Székelyhíd, Érmihályfalva, Kiskereki és Nagykároly. Az EGTC területén számos gazdasági és turisztikai lehetőség adódik. Az EGTC célja, hogy ezekre az erőforrásokra alapozva a partner önkormányzatokkal, a térségi civil szervezetekkel és a magáncégekkel közösen olyan fejlesztési programokat határozzon meg, amelyek a térség teljes gazdasági és szociális fellendülését biztosítják.

Az Európa-kapu ETT ${ }^{18}$ egy új intézményi eszköznek tekinthető, melynek székhelye Nyíradonyban van, viszont tagjai román és magyar önkormányzatok. Az ETT egyik fö előnye, hogy a területi együttmüködési pályázatokban (például a Magyar-román Területi Együttmüködési Program) a partnerség elvél nem kell a támogatónak igazolni, hiszen a szervezet alapból teljesíti az ilyen feltételeket. Ezen előny eredménye, hogy a közösen létrehozott intézmény nagyobb sikerrel pályázhat a határon átnyúló Európai Uniós finanszírozású pályázatokra.

Az EGTC Rendelet ${ }^{19}$ lehetőséget nyújt és megteremti azt az új, innovatív jogi keretet,amely lehetőséget nyújtott az akciókutatás eredményeként létrehozott intézmény megalakítására. A Rendeletnek köszönhetően egy olyan intézmény jött

17 EGTC: European Grouping of Territorial Cooperation (Európai Területi Együttmüködési Csoportosulás). A magyar törvényi szövegkörnyezetben az ETT is használatos, a rövidités jelentése Európai Területi Társulás. A jelen dokumentum további részeiben az ETT (Európai Területi Társulás) rövidítést használjuk.

${ }^{18}$ Az EGTC bejegyzéséröl szóló végzést a budapesti Törvényszék 2012. május 4-én adta ki.

19 AZ EURÓPAI PARLAMENT ÉS A TANÁCS 1082/2006/EK RENDELETE (2006. július 5.) az európai területi együttmüködési csoportosulásról 
létre a szük kutatási térben, mely a két állam, Magyarország és Románia, jóváhagyásával rendelkezik, viszont jogi személyiséget Európai Uniós intézménytől, mégpedig a Régiók Bizottságától kapta.

Egy másik létrehozott intézményi forma a Civil Klaszter, a térségi civil együttmúködési forma, mely a térségben aktív civil szervezeteket tömöríti magában. A Civil Klaszter szakmai munkáját az Európa-kapu ETT munkatársai és a térségi civil szervezetek munkatársai tartják össze. A térségben egyre több a rendezvény, a kezdeményezés melyek a civil klaszter eredményeként valósultak meg. Az eddig elért egyik legnagyobb eredmény, hogy sikerült több Nemzeti Összetartozás Kollégiuma által támogatott pályázatot nyerni.

A Nemzeti Együttmüködési Alap, Nemzeti Összetartozás Kollégiuma olyan pályázatokat támogat amelyek kedvezményezettei a határon átnyúló szervezetek is. A Civil Klaszter lehetőséget adott a találkozásra romániai és magyarországi civil szervezeteknek és támogatta közös partnerségek létrehozását is. Ezáltal létrejöttek olyan civil szervezetek közötti kapcsolatok, amelyek 3 és 5 millió forint között kaptak támogatást. Az egyik ilyen pályázat egy Ifjúsági Kárpátmedencei Konferencia melynek célja olyan partnerség kialakítása mely később a Duna Stratégiából részesülhetne forrásból.

Az akciókutatás főbb eredményei a következőek: a határ menti indikátor (Cbi), a létrehozott ETT és a megalapított Civil Klaszter. Az akciókutatás és az általam alkalmazott módszertan egy olyan új területfejlesztési eszközt hozott létre, amely képes a határ menti közösségek fejlesztésére. Újra bebizonyosodott a tény, hogy ahhoz, hogy fejlödés legyen egy térségben arra van szükség, hogy egy vagy több személy összefogja a helyi szereplőket és a térségi intézményeket, és együtt eldöntsék, hogy mi a közös cél és mit szeretnének fejleszteni.

Jelen akciókutatás bebizonyította, hogy lehetséges úgy fejleszteni, hogy nem áll rendelkezésre forrás. Nem csak a fejlesztési források azok, amik segítik a térségi 
fejlesztést, hanem maga az összefogás is olyan eredményeket generálhat, melyek hozzájárulnak a térség fejlesztéséhez.

Az ETT bejegyzése után és az akciókutatás végén az ETT alapítói felkértek, hogy igazgatóként vegyek részt a térségi szakmai munkában. Mivel akciókutatásom fontos eleme életemnek és az eredmények folytatását szerettem volna, 2012-ben Budapestről Nyíradonyba költöztem és elvállaltam az ETT vezetését.

Az elmúlt évben a következő feladatokat végeztem:

- áprilisban véglegesítettem a szervezet bejegyzését, minden kötelező dokumentumot elküldtünk a Régiók Bizottságának.

- regisztráltam a szervezetet az EGTC Platformra.

- májusban beadásra került az EGTC müködési pályázata a Wekerle Alapkezelöhöz. 8,5 millió forint támogatásban részesült az EGTC. Az elbírálási folyamatot követően a támogatás októberben érkezett a számlára, ezért megoldást kellett találnunk a cash-flow biztosítására. Nyíradony Város Polgármesteri Hivatala kölcsönzőt 2,5 millió forintot.

- Májusban részt vettünk a KIM és az NFÜ által szervezett EGTC szemináriumon, Budapesten a 2014-2020 pályázati időszak előkészítéséről.

- Beadásra kerültek NEA pályázatok, a térségi civil szervezeteknek segítettünk előkészíteni a pályázatokat

- Részvétel az IMIR felhasználói rendszer képzésén

- Májusban és júniusban több Magyarországi és Romániai településre látogattam el

- Júniusban elkészült a szervezet honlapja a www.europakapu.eu és a hozzá tartozó email címek

- Júliusban részt vettem az EGTC 1. fórumán, Salgóbányán július 3-án (a fórumot a Cesci szervezi szakemberek és fontos tisztségviselők részvételével). Célja egy közös EGTC stratégia kialakítása. 
- Augusztus. 28.-29-én részvétel az EGTC-k második fórumán Lovasberényben

- Szakmai anyag készítése a kisfüzethez mely bemutassa a magyarországi vonatkozású EGTC-ket (Elérhető a: $\underline{\text { http://cesci- }}$ net.eu/tiny mce/uploaded/EGTC-Snapshot(03)2012-10-03.pdf címen)

- Augusztusban az EGTC Munkaszervezete 2 fóállású és 2 fő négy órás munkavállalóval bővült

- Elkészült az EGTC nyolc településére vonatkozó leíró jellegü helyzetelemzés, mely alapja lesz a 2013-ban készülő Integrált Területi Beruházásnak

- Szeptemberben elkészült az EGTC-t bemutató kétnyelvü kiadvány (magyar és angol)

- Elkészültek reklámtárgyaink (logó, roll-up, tollak, jegyzettömbök, kiadvány, ajándéktáskák, stb.)

- Részvétel októberben a brüsszeli Open Days szakmai munkáim

- Mezőgazdásági munkacsoport 2012 novemberében Nyíradonyban

- Előadás Nagyváradon egy francia- magyar-román rendezvényen, bemutatásra került az Európa-kapu ETT

- Novemberben részt vettem a Mezőségi Civil Fórumon, mely Válaszúton Kolozs Megyében került megrendezésre

- Decemberben Temes Megyében, Zsombolyán és Magyarországon, Mórahalmon találkoztunk a BTC ETT képviselőivel

A kutatás egy másik eredménye az elkészült határ menti indikátor, mely a lezárt és a megvalósítás alatt lévő pályázatok értékelésében használható. Véleményem 
szerint, ha a Közös Szakmai Titkárság ${ }^{20}$ aktívabban részt vett volna az indikátor elkészítésében és segítette volna munkánkat, akkor az indikátor által nyújtott eredmények relevánsabbak lettek volna.

Véleményem szerint az indikátor a határ menti együttmüködésben módszertanilag számos szempontból fontos szerepet tölthet be, ugyanis:

- Felhívja a közfigyelmet a határ menti együttmüködésre, különösen a magyar-román határ mentén megvalósult intézményfejlesztési pályázatokra.

- Közéleti vitát indíthat arról, hogy mit várhatnak a határ menti övezet lakói a határ menti pályázatok hatályba ültetésével.

- Módszeres bizonyítékot kínál a határ menti intézmények reformtörekvéséröl és összehasonlítási alapként szolgál más európai uniós határ menti intézményi kezdeményezések elemzéséhez.

- A határ menti övezetek, partnerek közös problémáira hívja fel a figyelmet és sikeres gyakorlati megoldásokat ismertet.

A tudatosság fokozásán kívül a jelen kutatásnak volt egy másik célja is. Mivel a határ menti övezetek intézményfejlesztési kapacitásának mérési módszere nemzetközileg is kialakulatlan (ez különösen igaz a magyar-román határ mentén), ezért kutatásunk arra törekedett, hogy hozzájáruljon a mérési módszerek és mutatók fejlesztéséhez. Szeretném ezt az indikátort és a hozzá tartozó módszertant továbbfejleszteni annak érdekében, hogy a határ menti együttmüködésekre szánt források eredményesen legyenek elköltve és valós fejlesztést idézzenek elő.

\footnotetext{
${ }^{20}$ A Közös Szakmai Titkárság (Joint Technical Secretariat) a Magyar-Román Területi Együttmüködési Program Hatósága. A Hatóság Budapesten múködik, amelybe Magyarország és Románia delegál alkalmazottakat, akik a pályázatok megvalósításáért, felügyeleteért, szakmai koordinációjáért felelősek.
} 
Reményem szerint a kutatási eredmények felhívják a figyelmet a meglévő problémákra, és azt is reméljük továbbá, hogy az indikátor segítségével egy valós utánkövetési időszak lesz érvényben a „people-to-people” pályázók körében is. Általában 7 év az utánkövetési ${ }^{21}$ időszak, viszont az intézmények közötti kis projektek utánkövetésére a hatóságnak nincs egy bevált módszere. Úgy vélem, ha ez a módszer bevezetésre kerülne, akkor a kedvezményezettek kevesebb vállalást iktatnának be a pályázatok előkészítésénél vagy a vállalások reálisabbak lennének, ezáltal nőne a pályázatok minősége és a versengés a pályázók közt.

Egy másik fontos szempont az indikátor használatában az volna, hogy ezáltal a támogató rendelkezne egy olyan eszközzel, mely rámutatna a program valós eredményességére. Jelenleg az eredményességet a támogatók éves elemzések révén mérik, egyszerüen számosítva a támogatott pályázatokat és az elköltött összegeket. Viszont ha az indikátor bevezetésre kerülne, akkor konkrét eredményeket lehetne mérni és vizsgálni minden lezárt pályázatnál, nem csupán pénzügyi elszámolásokat értékelni.

$\mathrm{Az}$ indikátor egyes dimenzióit a kedvezményezettek saját belső értékelési eszközként is használhatják. Jelenleg a támogató nem kötelezi a kedvezményezetteket belső értékelésre, az egyetlen dokumentumok, amiket a pályázóknak be kell nyújtani az előrehaladási és pénzügyi beszámolókat. Úgy vélem, hogy az indikátor eredményességi és részvételi dimenzióban megtalálható kérdéseit a kedvezményezettek rendelkezésére lehetne bocsátani, és minden kedvezményezett szabadon eldönthetné, hogy mint belső, ellenőrzési eszközt használja-e vagy sem.

Mivel az indikátor számos olyan kérdést tartalmaz, melyek egy sikeres pályázat lezárása után fontosak lehetnek egy pályázónak, véleményem szerint a pályázati

${ }^{21}$ Az utánkövetési időszak az az időszak, mely a pályázat lezárása után következik, és a kedvezményezett köteles ebben a 7 éves időszakban az elért pályázati eredményeket fenntartani. 
ötlet véglegesítésében vagy a pályázat megírásának időszakában is hasznos lehet az indikátor kérdéseinek az ismerete.

Hiszen ezáltal egy lehetséges pályázó úgy tervezheti meg a pályázatát, hogy miután azt megvalósította, képes legyen a pályázati eredményeket, vállalásokat fenntartani. Röviden összegezve az indikátor elösegíti a valós és eredményre fókuszáló pályázatok elkészülését.

Mivel az indikátor kérdései általánosak, úgy vélem, hogy bármilyen más határ menti övezetben használható lehet. Az egyetlen kritérium, hogy az indikátor valós, használható eredményeket produkáljon, hogy olyan személy tegye fel a kérdéseket, aki megfelelő mértékben ismeri az adott övezetben a határ menti pályázatok támogatási és megvalósítási rendszerét. Amint azt már elmondtuk, ez egy olyan módszer, amit főként a program hatóságainak dolgozói, valamint projektmenedzserek és pályázati szakértők tudnak használni.

Ha az indikátor egyes kérdései módosításra kerülnek, akkor az használható lehet bármilyen pályázat elemzésére, tehát nem csak cross-border pályázatok elemzésére.

Célunk, hogy az indikátor pár éves eredményes használata és továbbfejlesztése után megpróbáljuk módszerünket népszerüsíteni nemzetközi szinten is, és ezáltal egyes európai szintü intézmények is átvehetik e módszer egyes részeit, és reményeink szerint egy bevált utánkövetési eszközként válik ismertté. 


\section{4 Áltanos javaslatok a határ menti együttműködési intézményrendszerről}

Az akciókutatásunk záró részeként szeretnénk leírni néhány olyan javaslatot, amelyek véleményem szerint hozzájárulnának a program jobb müködéséhez, valamint a határ menti együttmüködések eredményességét is növelhetnék.

\section{Javaslat: Nagyobb rugalmasság a program tervezésében, megvalósitásában és a szubszidiaritás elv erösítése}

Valamennyi program esetében az illetékes (a jelenlegi és leendő) tagállamok tárgyalásos úton elért konszenzusban állapodnak meg, a program tervezése tehát főként nemzeti szinten valósul meg. A program felépítésére és az intézményi keretre vonatkozó egyes megoldásokat az érintett határ menti régiók országai dolgozzák ki.

Javaslom, hogy a tervezési és a megvalósítási folyamatba a területi intézmények és a kedvezményezettek bevonása nagyobb mértékü legyen. A döntés tehát ne nemzeti szinteken, hanem helyi szinten történjen a programot érintő fontos kérdésekben. Itt föként arra gondolok, hogy a tervezési eljárásokban a helyi, térségi, határ menti övezet véleményét is ki kellene kérni.

A Torremolinosi Charta 1983-as elfogadása óta a területi kohézió elve fokozatosan nyert egyre nagyobb jelentőséget az Európai Unió kohéziós politikájában, míg végül a Lisszaboni Szerződéssel és a Területi Agenda 2020 elfogadásával a gazdasági és a társadalmi kohézió elvével teljesen egyenértékủvé vált.

A stratégiák elkészítése során ezért nem egy hagyományos értelemben vett helyzetértékelést kell készíteni, hanem javaslom a kohézióvizsgálat módszertanának az alkalmazását, amelynek fókuszában azon tényezők elemzése 
áll, amelyek segítik és amelyek gátolják a határ menti régióban a területi, gazdasági és társadalmi kohézió érvényre juttatását.

A határ menti stratégiák célkitüzéseinek megfogalmazásában azonban már nem ágazati alapon kell történnie a kivitelezésnek, hanem integrált területi megközelítéssel. Ennek az az oka, hogy a határ menti problémákat nem helyi problémaként kell kezelni, hanem a határmentiségben rejlö, de elfedett területi tőke érvényre jutását kell segíteni.

Olyan beavatkozásoknak kell megjelenniük az ilyen stratégiákban, amelyek a határon átnyúló, stratégiai megközelítéseket igénylik, és amelyek ténylegesen határon átnyúló megoldásokat tesznek szükségessé. Ezért ezeknek a beavatkozásoknak a területiség a központi elvük, hiszen megvalósításuk elképzelhetetlen a másik oldal aktív bekapcsolódása nélkül.

Ez az újszerü módszertan teljesen összhangban van az új kohéziós politika rendeletei által megkívánt integrált, stratégiai megközelítéssel, és ennek keretében kijelöl olyan integrált területi beruházásokat is, amelyeket a határ menti intézmények menedzselhetnek 2014 után.

\section{Javaslat: Átfogó Operativ Programok készitése a területi viszonyokhoz alkalmazkodva}

A jelenlegi Operatív Programok beavatkozásai és intézkedései minden határ menti övezetre megegyeznek. Ha összehasonlítjuk a magyar-szlovák és a magyarromán határ menti övezetet támogató program dokumentumait, akkor mindkét Operatív Programban egyforma beavatkozási területeket találunk. Javaslom, hogy az Operatív Program készítésénél az Irányító Hatóságok vegyék figyelembe az adott határ menti övezet sajátosságait és problémáit, és valós helyzetelemzést végezve kerüljenek megfogalmazásra a beavatkozási területek és program prioritások. 
A változás a 2014-2020-as programozási időszakban az, hogy nem ágazati, hanem tematikus koncentráció lép majd érvénybe. Ez azt jelenti, hogy az adott 11 terület közül a határ menti övezetre a közös tervezési hatóságoknak ki kell választaniuk 4 területet, és a támogatás csak azokra a fejlesztési típusokra lesz majd elérhető.

A tematikus koncentráció rendeletben elöírt prioritási területei a következőek:

1. a kutatás, technológiai fejlesztés és innováció erősítése;

2. az információs és kommunikációs technológiák hozzáférhetőségének, használatának és minőségének javítása;

3. a kis- és középvállalkozások, a mezőgazdasági (az EMVA esetében), és a halászati és az akvakultúra-ágazat (az ETHA esetében) versenyképességének javítása;

4. az alacsony szén-dioxid-kibocsátású gazdaság felé történő elmozdulás támogatása minden ágazatban;

5. az éghajlatváltozáshoz való alkalmazkodás, a kockázat megelőzés és kezelés ügyének támogatása;

6. a környezetvédelem és az erőforrás-hatékonyság propagálása;

7. a fenntartható szállítás támogatása és a kapacitáshiányok megszüntetése a főbb hálózati infrastruktúrákban;

8. a foglalkoztatás előmozdítása és a munkaerő mobilitásának támogatása;

9. a társadalmi befogadás előmozdítása és a szegénység elleni küzdelem;

10. beruházások az oktatás, készségfejlesztés és élethosszig tartó tanulás területén;

11. az intézményi kapacitás javítása és hatékony közigazgatás. 


\section{Javaslat: A város és a vidék közötti fejlödési különbségek mérséklésére támogatási szempontok bevezetése}

A jelenlegi pályázati rendszerben a kritériumok nem tesznek különbséget a város és a vidék között. Viszont amint az látható volt a kutatási eredményekből is, a vidéki intézmények intézményfejlesztési pontszáma alacsonyabb, mint a városi intézményeké, tehát sokkal nehezebb a vidéki intézményeknek pályázni.

Ennek érdekében úgy kellene az Operatív Programot kialakítani, hogy lehetőséget adjon a vidéki intézményeknek, hogy az általuk beadott pályázat sikeresen legyen elbírálva. Célszerü volna egyes prioritásokat csak a határ menti, a vidéken működő intézmények számára meghirdetni és a városoknak pedig külön egy másik prioritást hirdetni.

\section{Javaslat: Egyszerü és átlátható végrehajtó intézményi keretek}

A jelenlegi intézményi struktúra bonyolult és teljesen átláthatatlan. Minden országban a minisztériumok szintjén létezik egy hatóság, van egy közös Irányító Hatóság Budapesten (Joint Technical Secretariat, vannak területi irodák (Debrecen, Békéscsaba, Eger, Mátészalka, Miskolc, Pécs, Sopron, Szeged, Székesfehérvár, Szombathely, Zalaegerszeg, Szatmárnémeti, Nagyvárad, Arad, Temesvár stb.), és az egész rendszerre még rátevődik az ÁFA visszaigénylésével foglalkozó hatóság (melyek Budapesten vagy Bukarestben a Pénzügyminisztériumon belül müködnek).

A román partnereknek van még egy másik hatósága is, mégpedig a Külügyminisztérium, amelynek meg kell küldeni egy adatlapot arról, hogyha nemzetközi pályázatot nyújtanak be. Lehetne folytatni a megvalósításba bevont szervezetek számát tovább, hiszen vannak például kötelező közbeszerzéssel 
foglalkozó szervek. Javaslatunk szerint olyan struktúrát kell létrehozni, amely nem akadályozza, hanem elősegíti a határon átnyúló programok célkitüzéseinek teljesülését.

Véleményem szerint a helyi területi szintekre nagyobb döntési jogot kellene ruházni és a már kialakulóban lévő határ menti ETT-k legyenek azok, akik helyi szinten döntenek a támogatások elbírálásáról, akik kifizetéseket végeznek, és pályázati elszámolásokat vesznek át a kedvezményezettektől.

Az ETT-k lennének tehát azon területi egységek, amelyek egy adott pénzügyi keretet megkapnak és a helyi problémákat figyelembe véve támogatásokat nyújtanak.

Javaslom, hogy a 2014-2020-as pályázati időszakban célszerü lenne bevezetni a területi stratégia alapú támogatást. A támogatás lényege a LEADER-koncepciót követné, mégpedig a lentről felfelé építkezést: a problémák felismerését ETT szinten, a beavatkozások és megoldások keresését, a stratégiakészítést, valamint az elkészült stratégia támogatását egy keretösszeggel, amire majd az ETT írja ki a pályázatokat. Véleményem szerint ehhez a teljes aktuális pályázati rendszer átfogó reformjára lenne szükség.

Ez az új rendszer megoldást jelentene az 1. 2. és 3. javaslatban bemutatott problémákra is, hiszen az ETT lehetőséget ad a helyi lakosság és az érdekeltek bevonására, megteremti az olyan új és határon átnyúló, jogi személyiséggel rendelkező intézményi keretet, mely képes az Európai Uniós források befogadására, és képes a helyi igényekhez mérve e forrásokat a kedvezményezetteknek leosztani. 


\section{Javaslat: Pályázatok megvalósítása és finanszírozása -elöfinanszírozás és partnerség}

A lezárult pályázatok tapasztalata szerint a legtöbb nehézség a pályázók körében az önerő, illetve az előfinanszírozás területén, valamint a partnerségek, együttmüködések időtartamában jelentkezett.

A vizsgált pályázati eredményekből látható, hogy a kedvezményezettek főként közigazgatási intézmények, oktatási intézmények, önkormányzati társulások, kistérségek, regionális vagy nemzeti érdekeltségü megyei hatóságok.

A civil szervezetek és a magánszféra aktív főszereplöként nincs jelen a határ menti együttmüködésekben. Ha mégis, akkor olyan civil szervezetekröl van szó, amelyek országosan elismert szolgáltatásnyújtó szervezetek (tehát fő jövedelemforrásuk gazdasági tevékenységből származó profit). A helyi kis civil szervezetek a 2007-2013-as ETE Programból teljes mértékben kiszorultak, ugyanis nem tudták a pályázatok előfinanszírozását felvállalni.

A 2014-2020 közötti Operatív Programba be kellene építeni egyes mentesítéseket vagy előnyöket a civil szervezetek számára. Például előnyt kellene élvezzenek vagy pluszpontokat kellene kapjanak az értékelésnél az olyan pályázók, akik először pályáznak és vidéki településekröl származnak, vagy olyan civil szervezetek, melyek olyan tevékenységet szeretnének megvalósítani, melyeknek kedvezményezettjei a helyi lakosság (például közös, határon átnyúló fesztiválok, helyi termékeket népszerüsítő közös projektek, a határon átívelő közös turizmusfejlesztést célzó bemutatók, kisfilmek, kampányok stb.).

A pályázati nyelv a másik ok, ami a vidéki és a kisebb szervezetek pályázási kedvét szegi, ugyanis minden dokumentumot angol nyelven kell leadni. A nagyobb szervezetek pályázatíró cégekkel dolgoztatnak, vagy saját alkalmazottaik rendelkeznek megfelelő ismeretekkel ahhoz, hogy angol nyelven elkészítsék a pályázatot, és a megvalósítást is ugyanilyen módon ellássák. 
Véleményünk szerint az angol nyelvü pályázati rendszer sok jó, határon átívelö, valós fejlesztést előidéző projektötletet hagy feltáratlanul, és meggátolja a kisebb szervezetek pályázási lehetőségét.

A román-magyar kétnyelvűség visszaállítása az egész pályázati rendszerben nagymértékben elősegítené a pályázatok számának és minőségének a növekedését.

A pályázati listák elemzésekor kiderült, hogy a pályázók főként nagyobb szervezetek (ha civil szervezetekröl beszélünk), vagy közigazgatási, állami intézmények, melyek rendelkeznek (vagy rendelkeztek a PHARE CBC/INTERREG IIIA pályázatoknál) megfelelő önerővel. Jelenleg a pályázatok utófinanszírozás alapján müködnek, ami azt jelenti, hogy csak olyan szervezetek képesek megvalósítani egy pályázatot, amelyek rendelkeznek megfelelő anyagi erőforrással, jövedelemmel, bevétellel.

Ezt a rendellenességet állami szinten kellene orvosolni és a lehetséges pályázókkal közösen megoldásokat keresni. A jelenlegi eljárás az, hogy a nyertes pályázók banki kölcsönt igényelnek, melynek visszafizetésére a pályázat utófinanszírozása után kerül sor. Viszont ezt csak a magyarországi civil szervezetek tudják érvényesíteni, mivel a romániai bankok jelenleg nem adnak hiteleket a civil szervezeteknek.

A román bankok hitelpolitikájára kellene tehát a román Pénzügyminisztériumnak nyomást gyakorolnia, és közösen egy olyan konstrukciót felépíteni, mely biztosítaná, hogy a támogatott, pályázati szerződést aláírt civil szervezetek előnyös hitelhez jussanak.

A fő nehézségük a magyar civil szervezeteknek az, hogy a banki kölcsönök utáni kamatokat nehezen tudják törleszteni. Ha ez a rendszer marad a következő pénzügyi programozási időszakban is, akkor félő, hogy a pályázók köre egyre jobban beszükül, ezáltal a támogatások helyi jellegüekké válnak, és csak bizonyos szervezetek számára lesznek elérhetőek. 
A 2007-2013-as ETE Program kedvezményezettjeinek listáit vizsgálva is megtalálhatóak olyan közismert civil szervezetek, melyek minden évben megjelennek visszatérö pályázókként, ugyanakkor a vidéki, kisebb szervezetek száma elenyésző a nyertes listákon. Ezért a jövőbeli határ menti együttmüködési programok kidolgozása során érdemes lenne a pozitív diszkrimináció eszközével élve az elérhető forrásokat elkülöníteni, és alacsonyabb öneröt elöírni a kisebb településekről származó pályázók számára. 


\section{IRODALOMJEGYZÉK}

Ágh, Attila (2002): Demokratizálás és európaizálás. Villányi úti könyvek, Budapest.

Ágh, Attila (2008): Társadalmi közép és társadalmi kapacitás-a magyar közpolitikai rendszer gyermekbetegségei, In Politikatudományi Szemle XVII/3. pp.7-33.

Anheier, k. helmut - glasius, Marlies- kaldor, Mary (szerk.) (2004): globális civil társadalom. Budapest, Typotex, pp.32-33.

Asociația Pro Democrația (2008), Parteneriat pentru bună guvernare și dezvoltare, A tanulmány elérhető a URL: http://www.apd.ro/files/publicatii/Buna guvernare la romanighid_de bune practici.pdf címen, megtekintve 2012.02.28

Alexis de TOCQUEVILLE (1993): Az amerikai demokrácia, Európa, Budapest, pp. 973-974.

Arisztotelész: Politika. Fordította Szabó Miklós (1994). gondolat, Budapest, pp. 71-84.

Arato, Andrew. - COHEN, Jean. (1989): Social Movements, Civil Society and the Problem of Sovereignity. In: Praxis International 5. pp.84-86.

Bartal Anna Mária (2005): Nonprofit elméletek, modellek, trendek. századvég, Budapest, pp.20-21. 
Baranyi Béla (2007): A határmentiség dimenziói Magyarországon, Campus Kiadó, Budapest, pp.3-21.

Baranyi Béla-Dancs-Balcsók (2001): Határmentiség és határon átnyúló kapcsolatok lakossági szemszögből a román-magyar határ két oldalán. Kérdőíves vizsgálat. Debrecen, MTA Regionális Kutatások Központja Alföldi Tudományos Intézet Debreceni Osztálya. Kézirat

Bartal Anna Mária (2010): önkéntesek és nem-önkéntesek a 2008. évi Európai Érték vizsgálat tükrében, avagy Aki önkéntes nagyobb valószínűséggel boldogabb és elégedettebb? www.volunteermotivation.hu

Blahó András-Prandler Árpád (2001): Nemzetközi szervezetek és intézmények. Aula

Bădulescu Alina, Bucur Cătălin-Adrian, Public Services and the Euro-Regional Cooperation, Conference Proceedings "European Integration - New Challenges" EINCO 2012, 8th Edition, 25-26 mai 2012, Analele Universităţii din Oradea seria Științe Economice, nr. 1/2012, iunie 2012

Bucur, Cătălin-Adrian (2009), Creşterea şi dezvoltarea regională şi euroregională, Teză de disertaţie, Universitatea din Oradea, Facultatea de Ştiinţe Economice, Oradea

Bucur Cătălin-Adrian, Cooperation Between Institutions of Public Order and Safety from Bihor (Romania) and Hajdu-Bihar (Hungary): A Case Study, Conference Proceedings "European Integration - New Challenges" 
EINCO 2012,8th Edition, 25-26 mai 2012, în curs de publicare în Analele Universității din Oradea seria Științe Economice, nr. 1/2012, iunie 2012

Bucur Cătălin-Adrian (2011): Relaţiile transfrontaliere: etape și stadii relevante, în volumul: România şi provocările crizei economice - răspunsul tinerilor economişti / editori: prof.univ.dr. Alina Bădulescu, prof.univ.dr. Anca Dodescu -Oradea: Editura Universităţii din Oradea

Ben-Porath, Y (1980).: The F-connections: Families, Friends, and Firms, and the Organization of Exchange. In Population and Development Review

Bourdieu, Pierre (1998): Gazdasági tőke, kulturális tőke, társadalmi tőke. In Lengyel Gy-Szántó Z.(szerk.): Tőkefajták: A társadalmi es kulturális erőforrások szociológiája, Budapest, AULA Kiadó. pp.157-168.

Castells, Manuel (2005): The Network Society: from Knowledge to Policy (in: Manuel Castells - Gustavo Cardoso (eds.): The Network Society: From Knowledge to Policy, The Johns Hopkins University Press, Center for Transatlantic Research Relations, Washington, DC), pp.3-23, pp. 373-405.

Cerkez, Mirela (2009), Evaluarea programelor si politicilor publice. Teorii, metode si practici, Editura Polirom, Iași

Cohen Jean L.-Arató Andrew (1992): Civil Society and Political theory. BostonCambridge, MIT, pp.83-117.

Colas, Dominiqae (1997): Civil Society and Fanaticism: Conjoined Histories. Amy Jacobs, Stanford: Stanford University Press, pp.237-343. 
Communication from the Commission of the European Community of 6 June 1997 on promoting the role of voluntary organisations and foundations in Europe".COM(1997) 241

Coleman, James Samuel (1994): Társadalmi tőke. In: A gazdasági élet szociológiája (Szerk.: Lengyel Gy.-Szántó Z.)., Aula Kiadó, Budapest, pp. 99.

Coleman, James Samuel (1998): Gazdasági tőke, kulturális tőke, társadalmi tőke. In: Tökefajták: A társadalmi és kulturális erőforrások szociológiája (Szerk.: Lengyel Gy. - Szántó Z.). Aula Kiadó, Budapest. pp.11-24.

Commission of the European Communities (2001.07.25): White Paper on European Governance, Brussels (COM/2001/428final)

DeBresson, Ch. and Xioping Hu (1999), "Techniques to Identify Clusters of Innovative Activity: A New Approach and a Toolbox", Ed. Edward Elgar.

DEWULF A. - CRAPS M. - BOUW EN R. - TAILLIEU T. - PAHL-WOSTL C. (2005): Integrated management of natural resources: dealing with ambiguous issues, multiple actors and diverging frames.

[URL]:http://www.newater.uos.de/training/KLC-Ebooklet-CDROM-27-

012009_files/Dewulf\%20et\%20al\%20\%20\%282005\%29\%20\%20Integrate d\%20management\%20of\%20natural\%20resou.pdf letöltés dátuma: 2012. május 12., pp.19-22.

Elgström, Ole - Jönsson, Christer (2005): European Union Negotiations Processes, Networks and Institutions, Abingdom, Oxobn, Routledge, pp.21-23. 
Enyedi György (1996): Regionális folyamatok Magyarországon az átmenet időszakában. Budapest. Ember-Település-Régió sorozatban

Éger György (1997): Régió, határ, kisebbség. in: Zsinka László (szerk.): Modernizáció és regionalitás. A külpolitika térbeli összefüggései. Budapesti Közgazdaságtudományi Egyetem Közszolgálati és Tanulmányi Központ

Éger György (1998): Az eurorégió mint az európai integráció sajátos térbeli vetülete, Külpolitika, tél Faltan, Lubomir - Krivy, Vladimir: Slovakia (1999): Changes in Public Administration. in: E. Kirschner (ed.): Decentralization and transition in the Visegrad. MacMillan Press, Ltd.

Európa 2020: Az intelligens, fenntartható és inkluzív növekedés stratégiája $\operatorname{COM}(2010) 2020,2010.03 .03$

European Charter of Local Self-Government - Helyi Önkormányzatok Európai Chartája ETS No. 122

European Commission (2002): Regional Clusters in Europe, Observatory of European SMEs. No. 3. Enterprise Direcorate General of European Commission. Luxemburg

European Commission (2005): Institutional Assessment and Capacity Development -Why, what and how?, Air delivery methods concept paper a cotribution a development thinking, pp.7-18. 
Flap, Henrik (2002).: No Man is an Island: The Research Programme of a Social Capital Theory. In Favereau, O.-E. Lazega (eds.): Conventions and Structures in Economic Organization: Markets, Networks and Organizations. Oxford, Oxford University Press.

Forman Balázs (2001): Az Európai Unió Strukturális és Előcsatlakozási alapjai. Európai Bizottság Magyarországi Delegációja

Forman Balázs (2000): Regionális politika az Európai Unióban. VÁTI, Budapest.

Fukuyama, Francis (1999).: Social Capital and Civil Society, www.imf.org/external/pubs/ft/seminar/1999/reforms/fukuyama.htm

Fukuyama, Francis (1995), Trust: The social virtues and the creation of prosperity. New York: Free Press., pp:10.

Fukuyama, Francis (2000): A nagy szétbomlás. Az emberi természet es a társadalmi rend újjászervezése. Budapest, Európa Könyvkiadó.

Gazdag Ferenc (2000). Az Európai Unió közös kül- és biztonságpolitikája. Osiris Kiadó, Budapest

Grúber Károly (2002): Európai identitások: régió, nemzet, integráció, Pro Minoritate Könyvek, Osiris-BIP, Budapest

Granovetter, Mark (1973): The Strength of Weak Ties. In American Journal of Sociology, Volume 78, Issue 6, pp.1360-1380. 
Hall, A.Peter - Taylor, C.R.Rosemary (1996): Political Science and the Three New Institutionalisms. Political Studies 44, pp.948-951

Hanifan, Lyda Judson. (1916): The Rural School Community Center In: Annals of the American Academy of Political and Social Science, Boston, pp.130138.

Hanifan, Lyda Judson (1920): The community center. Boston: Silver, Burdett \& Company

Hardi, Tamás (2008): A határtérség térszerkezeti jellemzői, In: Tér és Társadalom 22. evf./3, pp.5-16.

Horváth Gyula (1998): Európai regionális politika. Dialóg Campus Kiadó. Budapest-Pécs

Horváth Gyula (szerk.)(2000): A régiók szerepe a bővülő Európai Unióban. RKK, Pécs.

Horváth Gyula (2001): Regionális támogatások az Európai Unióban. Osiris Kiadó, Budapest

Horváth Gyula (2005): Magyarország térszerkezete és a régió intézménye. Területi. Statisztika 8. (45.) évf. 4. sz. pp.310-323.

Hurjui, Marcela Cristina, (2006), Teorii ale dezvoltarii regionale, în Anale Universitatea Stefan cel Mare, Suceava 
Illés Iván (1997): Magyarország a regionális együttmüködésben. in: Zsinka László (szerk.): Modernizáció és regionalitás. A külpolitika térbeli összefüggései. Budapesti Közgazdaságtudományi Egyetem Közszolgálati és Tanulmányi Központ

Inglehart, R. 1990: Culture Shift in Advanced Industrial Society. Princeton, New Jersey, Princeton University Press, pp.30-41

Jenei György - Kuti Éva (2007): A civil szféra szerepe - lehetséges feladatok és hatékonysági következmények. In: Báger Gusztáv és Czakó Erzsébet(szerk): A közszféra és a gazdaság versenyképessége. Állami Számvevőszék Fejlesztési és Módszertani Intézet, Budapest. pp. 129-169.

Jenei György - Hajnal György (2008): The Study of Public Management in Hungary. In: Walter Kickert(szerk):The Study of Public Management in Europe and the US. Routledge, London-New York.

Jacob Levy Moreno (1934): Who shall survive? Foundations of sociometry, group psychotherapy and sociodrama, Beacon House New York., pp.101123.

Jacobs, Jane (1961): The Death and Life of Great American Cities. New York, Random Publishing.

Jordan, Grand and Klaus Schubert (1992): A Preliminary Ordering of Policy Network Labels, in European Journal of Political Research, Vol.21, pp.727. 
Karen Dawisha, Bruce Parrott (1997): Politics, power and the struggle for democracy in South-East Europe, Cambridge: University Press

Kaiser Tamás (2006): A horizontális európaizáció és a határ menti együttműködések. In: Kaiser T.(szerk.): Stratégiai kutatások-Magyarország 2015, Hidak vagy sorompók? A határokon átívelő együttmüködések szerepe az integrációs folyamatban, Budapest, Új Mandátum Kiadó

Keating, Michael (1992) Regional Autonomy in the changing state order. a framework of analysis -Regional Politics and Policy, Vol.2 No 3. Autumn, pp.45-61.

Kiss J. László (1997): Sokoldalú együttmüködés Közép- és Kelet-Európában - az EU és a szubregionális identitás. in: Zsinka László (szerk.): Modernizáció és regionalitás. A külpolitika térbeli összefüggései. Budapesti Közgazdaságtudományi Egyetem Közszolgálati és Tanulmányi Központ

Kjaer, Anne Mette (2004), Governance, Cambridge: Polity Press.

Kooiman, Jan (2003), Governing as Governance, London: Sage Agenda 21-37. fejezete szerint (UNCED-1992),

Lados, Mihály (2006): Az Intereg-Phare CBC projektek típusai és tapasztalatai. In: Kaiser Tamás (szerk.): Hidak vagy sorompók? A határon átívelő együttmüködések szerepe az integrációs folyamatban. Stratégiai kutatások - Magyarország 2015. Új Mandátum Könyvkiadó, Budapest, pp. 204-229. 
Locke, John (1986): Értekezés a polgári kormányzat igazi eredetéről, hatásköréröl és céljáról, Budapest, 1986, pp.126-141.

Magyarország-Románia határmenti együttmüködési Operatív Program 20072013, http://www.huro-cbc.eu/ , 2007. december 21-én jóváhagyta az Európai Bizottság

Morgan, Peter (1997): The design and use of capacity Development indicators, paper prepared for the Policy Branch of Sida, pp.14-39.

Martinez, J. Oscar (1994): The dynamics of Border Interaction: New Approaches to Border Analisys.-Schofield C.H (ed.), Global Boundaries (World Boundaries Series 1). Routledge, London-New York, pp.1-15.

Maskell, P. - Törnqvist, G. (1999): Building a Cross-Border Learning Region. Copenhagen Business School Press, Copenhagen.C.W.K. Gleerup, Lund.

Max Weber (1982): A protestáns etika és a kapitalizmus szelleme, Gondolat, Budapest, pp.279-287.

Merkel, Wolfgang (2004): Embedded and Defective Democracies. Democratization, Vol. 11, No. 5, In: Special Issue, Consolidated or Defective Democracy? Edited by Aurel Croissant-Wolfgang Merkel, pp.33-58.

Nárai Márta, Rechnitzer János (1999): Elválaszt és összeköt - a határ. MTA RKK. Győr-Pécs 
Nemes, Nagy J. (1998), Tér a társadalomkutatásban, Hilscher Rezs1 Szociálpolitikai Egyesület, Budapest.

Nemes, Nagy J. (szerk.) (2005), Regionális elemzési módszerek, ELTE Regionális, Földrajz tanszék, MTA-ELTE Regionális Tudományi Tanulmányok, Budapest, pp.284-286.

Netwin Kft (2007): Klaszterek Magyarországon - fejlödési kilátásaik, szerepük a KKV-k fejlődésében, növekedésében. (Clusters iin Hungary development prospects, their role in the development and growth of SMEs) Nemzeti Kutatási és Technológiai Hivatal“, pp.61-62.

Nielsen K.A. - Svensson L.G. (2006) (Szerk.): Action Research and Interactive Research: Beyond practice and theory. Maastricht: Shaker Publishing B.V., pp.89-92.

North, C. Douglass (1990): Institutions, Institutional Change and Economic Performance. Cambridge University Press, Cambridge, pp. 3-5.

Novotny Gábor (2003): Határon átnyúló városhálózatok: újabb intézményi divat az európai határon átnyúló együttmüködésekben? - Tér és Társadalom, 17. 1. pp. $2-12$.

Nowackiné Tóth Katalin (2010): A partnerség elve a Strukturális Alapok felhasználásában, MKI, 10. 
Nunberg, Barbara (2000): Ready for Europe: Public Administration Reform and European Union Accession in Central and Eastern Europe, Washington D. C.:The World Bank, pp.171-196.

OECD (1999): Boosting innovation-the cluster approach, Ed,Head of Publications Service, OECD Publications Service, pp.7-9.

Ocskay Gyula, (2012): Az Európai Területi Együttmüködési Csoportosulás, az EGTC (European Grouping of Territorial Cooperation) lehetőség és fejlesztések, Nemzetközi Konferencia előadás: A határ menti együttmúködés: az új lendület eszközei, Nagyvárad, Románia

OXFORD Politikai szótár (2001), Kiadó Univers Enciclopedic, Bukarest, 2001, pp.419-420.

Pálné, Kovács Ilona (2005), Közigazgatási reformok, uniós tagság, regionalizmus, Budapest: Timp Kft. Kiadó

Pálné Kovács Ilona (2001): Regionális politika és közigazgatás. Dialóg Campus.

Pavluska Valéria (2006): Marketingelméleti következtetések a civil társadalom és a civil nonprofit szervezetek természetének vizsgálatából. Doktori Értekezés, Pécsi Tudományegyetem (kézirat), Pécs, pp.28-29.)

Porter, Michael (1997), Knowledge-based Clusters and National Competitive Advantage, presentation to Technopolis 97, 12 September, Ottawa. 
Putnam, Robert D (1993.: Making Democracy Work: Civic Tradition in Modern Italy. Princeton, 1993, Princeton University Press, pp.163-167., pp. 175

Putnam, Robert D (2000): Bowling Alone. The Collapse and revival of American community. New York, Simon and Schuster, pp.228-229, pp.324-325.

Putnam, R. D. (ed.) (2002): Democracies in Flux: The Evolution of Social Capital in Contemporary Societies. New York, Oxford University Press., pp.189190.

Rechnitzer János (1999): Határ menti együttmüködések Európában és Magyarországon.in: Nárai Márta- Rechnitzer János (szerk.): Elválaszt és összeköt - a határ. MTA RKK Pécs-Győr

Rechnitzer J. (2001): A határ menti regionális együttmüködés sajátosságai és a fejlesztés lehetséges irányai. Pro Minoritate 2001/Nyár

Salamon, Lester M - Helmut Anheier (1992): In Search of the Nonprofit Sector II: The problem of classification, Working Papers of the Johns Hopkins Comparative Nonprofit Sector Project, no. 3. Baltimore: The Johns Hopkins Institute for Policy Studies

Salamon, Lester M. -Helmut K. Anheier (1996): "Social Origins of Civil Society: Explaining the Nonprofit Sector Cross-Nationally." Working Papers of the Johns Hopkins Comparative Nonprofit Sector Project, no. 22, edited by Lester M. Salamon and Helmut K. Anheier. Baltimore: The Johns Hopkins Institute for Policy Studies, pp.3-4. 
Smith Adam, Adam Ferguson and the Division of Labour, Economica, vol.35, no.139, August 1968.

Süli-Zakar István (1996): A határon átnyúló kapcsolatok erősítésének lehetőségei a Kárpátok Eurorégió területén. in: Pál Ágnes -Szónokyné Ancsin Gabriella (szerk.): Határon innen - határon túl. Szeged

Süli-Zakar István (1997):A Kárpátok eurorégió a régiók Európájában. Educacio. 3.

Süli-Zakar István (2001): A határmentiség az euro-atlanti folyamatok tükrében, különös tekintettel a Kárpátok Eurorégió müködési területére. Baranyi Béla (szerk.): A határmentiség kérdőjelei az Északkelet-Alföldön. MTA Regionális Kutatások Központja Pécs

Tagil, Sven (2000):Regions in Central Europe: The Legacy of History (Central European Studies), C Hurst \& Co Publishers Ltd- Purdue University Press, pp.129-144.

The Role and Contribution of Civil Society Organisations in the Building of Europe", Brussels, (European Official Journal C329, 17,11,1999)

The Commission and Non-Governmental Organisations: Building a Stronger Partnership; COM/2000/11final, Brussels

Tóth József (1996): A regionális fejlődés kezdetei és mai problémái a Kárpátmedencében. in: Pál Ágnes -Szónokyné Ancsin Gabriella (szerk.): Határon innen - határon túl. Szeged 
Vincze, Gábor (2000): A romanizálástól az államosításig, (URL): http://primus.arts.u-szeged.hu/doktar/texts/hargita.html , 2012.07.05

Agenda 2000 - Vol. I: For a stronger and wider Union - Vol. II: The challenge of enlargement, COM/97/2000 final - Vol. I , COM/97/2000 final - Vol. II

Héthatáron (2004): VÁTI elektronikus publikáció, URL http://www.vati.hu/files/articleUploads/5526/hu_sk_kpa_2003_final.pdf

Shafritz, Jay M. (1986): Mandates, In Defining Public Administration, ed. Boulder Westview Press, pp-79-80.

\section{Internetes adatforrások}

Központi Statisztikai Hivatal honlapja Magyarországon : www.ksh.hu

Központi Statisztikai Hivatal honlapja Romániában: $\underline{\text { www.insse.ro }}$

ENSZ Fejlesztési Programja www.undp.org

Global Research Development Center,Intézményi kapacitás elméletek, elérhető a URL címem: (GDRC), http://www.gdrc.org/uem/capacity-define.html

Az Európai Unió EGTC Platformja: https://portal.cor.europa.eu/egtc/enUS/Pages/welcome.aspx 
VÁTI (Magyar Regionális Fejlesztési és Urbanisztikai Nonprofit Kft.) http://www.vati.hu/index.php?page=main\&menu=19497\&langcode=hu

Romániai Regionális Fejlesztési és Közigazgatási Minisztérium www.mdrt.ro Magyarország-Románia Határon Átnyúló Együttműködési Program 2007-2013 http://huro-cbc.eu/hu/

Magyarország-Szlovákia Határon Átnyúló Együttmüködési Program 2007-2013 http://www.husk-cbc.eu/ 


\section{PUBLIKÁCIÓK JEGYZÉKE}

Csetnek, Tünde Tímea (2013), Grupările europene de cooperare teritorialăinstrumente ale dezvoltării în zona de graniță (European Groupping of territorial cooperation-instruments of development in the border area), In.Revista Transilvană de Științe Administrative (Transylvanian Review of Administrative Scinces)

Csetnek, Tünde Tímea (2013), Dezvoltare instituţională în zona de graniță româno-maghiară (Institutional development in the romanian-hungarian cross border area) In.Revista Transilvană de Științe Administrative (Transylvanian Review of Administrative Scinces)

Csetnek, Tünde Tímea (2012), Kapacitás-és intézményfejlesztés a románmagyar határ menti övezetben, In: Észak-magyarországi Stratégiai Füzetek, IX évfolyam, I. szám 2012, pp.103-111.

Csetnek, Tünde Tímea (2012), Intézményfejlesztés a román-magyar határ mentén, In: Fiatal Regionálisták VII. Konferenciáján kiadott Konferencia kötet, Győr, pp.99-113.

Csetnek, Tünde Tímea (2010), Intézményfejlesztés a magyar-román határ mentén PHARE CBC/INTERREG alapokból, In: RODOSZ Konferencián kiadott kötet, Kolozsvár, pp.81-101. 
Csetnek, Tünde Tímea (2008), Határ menti együttműködés, mint közpolitikahatár menti pályázat elemzése, In: RODOSZ Konferencián kiadott kötet, Kolozsvár, pp.114-156.

Csetnek, Tünde Tímea (2007), A határ menti együttmüködések szerepe, In: Pro Scientia Administrativa Évkönyv, Status Kiadó, (magyar nyelvü folyóiratcikk) pp.33-42

Csetnek, Tünde Tímea (2006), The role of cross-border cooperation in light of Romania's integration into the European Union, In. Cercetări, studii și abordări în științele umaniste. Politologie/Research, studies and Approaches in the Human Science. Politology (román nyelven kiadott könyv) pp.139177. 


\section{MELLÉKLETEK}

1.melléklet: A kutatás keretében végzett szervezeti lekérdezés kérdőíve

\section{Általános kérdések}

1. A projekt milyen típusú támogatásból valósult meg?

PHARE CBC Románia-Magyarország

$\square$ INTERREG IIIA Magyarország-Románia

$\square$ Más határ menti program:

2. Milyen hosszú volt a megvalósított projekt futamideje?

12 hónap

$\square 24$ hónap

$\square$ Egyéb: ___ hónap (Kérem, írja be a megfelelő hónapok számát!)

3. Mi volt a „people to people” projekt fö témája?

$\square$ Környezetvédelem

$\square$ Turizmus

$\square$ Ifjúság

$\square$ Népi hagyományok ápolása

$\square$ Integrált településfejlesztés

$\square$ Szociális problémák

$\square$ Helyi termékek

$\square$ Oktatás/képzés 
Foglalkoztatás

$\square$ Más:

4.Számszerűsítse, sorolja fel a pályázat kedvezményezetteit!

Közvetett: fó

Közvetlen: fó

Intézményi dimenzió kérdései

5. Véleménye szerint a megvalósított beruházások/szolgáltatások milyen mértékben idézték elő az alábbi változásokat?

\begin{tabular}{|c|c|c|c|c|c|}
\hline Kijelentés & $\begin{array}{l}\text { Teljesen } \\
\text { egyetérte } \\
\mathbf{k}\end{array}$ & $\begin{array}{l}\text { Egyet } \\
\text { értek }\end{array}$ & $\begin{array}{l}\text { Nem } \\
\text { értek } \\
\text { egyet }\end{array}$ & $\begin{array}{c}\text { Nem } \\
\text { jellemzó } \\
\text { pályázatu } \\
\text { nkra }\end{array}$ & $\begin{array}{c}\text { Nem } \\
\text { válaszolo } \\
\mathbf{k}\end{array}$ \\
\hline $\begin{array}{c}\text { Innovatív eljárások } \\
\text { bevezetése és alkalmazása }\end{array}$ & & & & & \\
\hline $\begin{array}{l}\text { A meglévő erőforrások } \\
\text { hatékonyabb használata }\end{array}$ & & & & & \\
\hline $\begin{array}{c}\text { Új, eddig nem létező } \\
\text { szolgáltatás bevezetése }\end{array}$ & & & & & \\
\hline $\begin{array}{c}\text { A } \\
\text { szolgáltatások/tevékenysége } \\
\text { k ellátásának minősége } \\
\text { növekedett }\end{array}$ & & & & & \\
\hline A munkakörülmények & & & & & \\
\hline
\end{tabular}




\begin{tabular}{|c|l|l|l|l|l|}
\hline javultak & & & & & \\
\hline $\begin{array}{c}\text { A határ menti partnerek és } \\
\text { lakosság együttmúködését } \\
\text { ösztönözte }\end{array}$ & & & & & \\
\hline
\end{tabular}

6. Az elért eredmények jelenlegi fenntartása milyen jellegü erőforrásokat igényel?

Humánerőforrások (munkatársaik tevékenységei)

Tárgyi eszközök

Egyszeri pénzügyi forrás

Rendszeres pénzügyi forrás

Más erőforrások (Kérem, részletezze!):

7. A projekt eredményei a pályázat vége után milyen módon voltak népszerüsítve? (Több lehetséges választ is bejelölhet!)

$\square$ Saját szervezetünk holnapján.

Saját és partnerszervezetünk honlapján.

Csak a partnerszervezet honlapján.

A partnerrel közösen tevékenységeket valósítottunk meg saját erőforrásból (pl. szóróanyagok, közös rendezvények, vagy bármilyen más közös 
kezdeményezés, melynek célja a lezárt projekt eredményeinek népszerüsítése volt).

Saját szervezetünk valósított meg saját tevékenységeket (pl. szóróanyagok, rendezvények, vagy bármilyen más kezdeményezés, melynek célja a lezárt projekt eredményeinek népszerüsítése volt).

Nyomtatott sajtóban.

Más nyomtatott, elektronikus kiadványban.

Más, eredmények népszerüsítésére szolgáló eszközök által (Kérem, részletezze!):

8. Milyen változásokat idézett elö az intézmény életében az Ön által megvalósított pályázat?

10. Annak, hogy az Ön szervezete pályázhasson a program keretében, mi volt a legnagyobb korlátja/akadálya? (Maximum 3-at jelöljön be és kérjük, rangsorolja! 1-es a leginkább jellemző.)

¿ önrész hiánya

$\square \quad$ elégtelen informatikai eszközök 

$\square \quad$ elképzelések hiánya
$\square \quad$ együttmüködés hiánya
$\square \quad$ szervezés hiánya
$\square \quad$ hiányos forrás koordináció
$\square$ hiányos szakmai
$\square \quad$ államigazgatási szervezetek rossz
háttértámogatás együttmüködése
$\square \quad$ nyelvi akadályok
$\square$ egyéb:

9. A legelső elnyert magyar-román határ menti pályázat lezárását követően, milyen más határ menti pályázatot valósított meg? (Sorolja fel a pályázatokat, cím és témakör megjelölésével!)

12. A következő kijelentések közül melyikkel ért egyet és melyikkel nem?

\begin{tabular}{|c|c|c|c|}
\hline Kijelentés & Egyetértek & $\begin{array}{c}\text { Nem értek } \\
\text { egyet }\end{array}$ & $\begin{array}{c}\text { Nem } \\
\text { válaszolok }\end{array}$ \\
\hline A pályázati támogatásból „megvásárolt” & & & \\
\hline
\end{tabular}




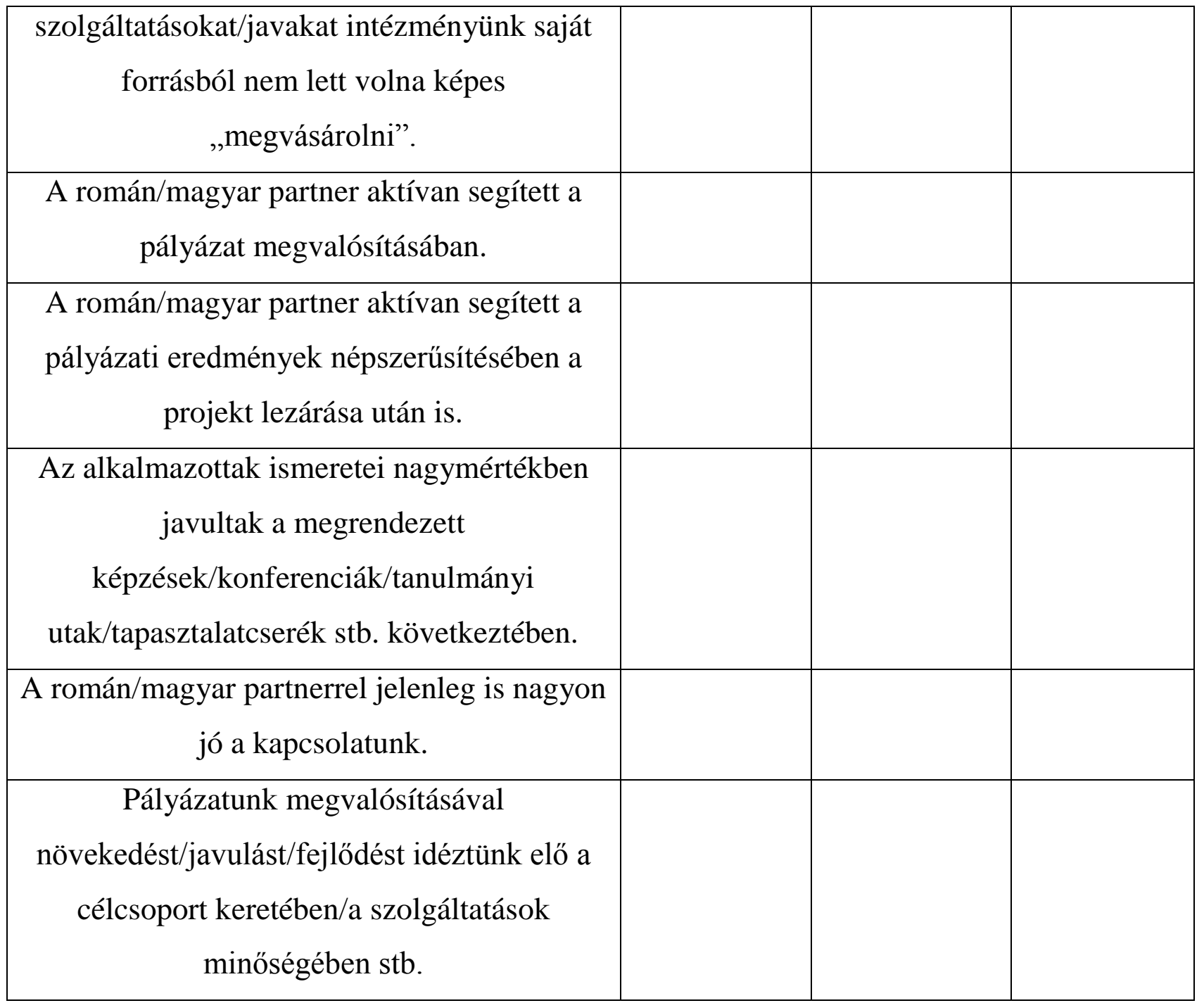

\section{A román/magyar partner intézménnyel:}

Több éve együttmüködési kapcsolatban voltam, mikor megvalósult a PHARE CBC/INTERREG IIIA projekt.

Pár hónapja együttmüködési kapcsolatban voltam, mikor megvalósult a PHARE CBC/INTERREG IIIA projekt.

Az együttmüködést kizárólag a megvalósult projekt idejére lehet lehatárolni.

Más: 
14.A pályázat lezárása után hogyan folytatódott az együttmüködés a román/magyar partnerrel?

\begin{tabular}{|c|c|c|c|}
\hline Kijelentés & Igen & Nem & $\begin{array}{c}\text { Nem } \\
\text { válaszolok }\end{array}$ \\
\hline Volt kb. 1-3 munkatalálkozónk. & & & \\
\hline Volt kb. 4-8 munkatalálkozónk. & & & \\
\hline $\begin{array}{l}\text { „Volt több munkatalálkozónk (Kérem, } \\
\text { számszerüsítse!)”. }\end{array}$ & & & \\
\hline $\begin{array}{l}\text { Folytattuk a lezárt pályázatot saját forrásokból } \\
\text { és közösen dolgoztunk az eredmények } \\
\text { fenntartásán. }\end{array}$ & & & \\
\hline $\begin{array}{l}\text { Új közös pályázatot készítettünk és kaptunk } \\
\text { támogatást. }\end{array}$ & & & \\
\hline $\begin{array}{l}\text { Új közös pályázatot készítettünk és nem } \\
\text { kaptunk támogatást. }\end{array}$ & & & \\
\hline $\begin{array}{l}\text { Jelenleg is tarjuk a kapcsolatot, de nem } \\
\text { pályázunk közösen. }\end{array}$ & & & \\
\hline
\end{tabular}

15. A lezárt pályázat összhangban volt az intézményi fejlesztési stratégiával?

Igen, teljes mértékben.

Igen, csak részben.

Nem jellemző.

A szervezetnek nincs intézményi fejlesztési stratégiája.

Más: 


\section{Humánerőforrás dimenzió kérdései}

16.Ki(k) írta(k) és vett(ek) részt a pályázatírásban és a megvalósításban?

$\square \quad$ Saját munkatársak.

$\square \quad$ Saját munkatársak és külső szakértő(k) közösen.

$\square \quad$ Pályázatíró cég.

$\square \quad$ Más:

17.A pályázat keretében létesített új munkahelyek kizárólag a pályázati támogatás időszakában léteztek?

$\square$ Igen

$\square$ Nem

17.1 Amennyiben a fenti kérdésre NEM a válasz, kérem, írja le, hogy a projekt befejezése után átlagosan mennyi ideig léteztek a munkahelyek/beosztások! 
17.2 Ha a munkahely/beosztás már megszünt, kérem, irja le röviden, hogy mi volt ennek az oka!

\section{Az Ön szervezetében a dolgozók jellemzői:}

\begin{tabular}{|c|c|c|c|c|}
\hline $\begin{array}{c}\text { Jellemzó } \\
\text { AGEN }\end{array}$ & $\begin{array}{c}\text { Hány fó? } \\
\text { (létszám) } \\
\text { akik pályázati } \\
\text { tapasztalattal } \\
\text { rendelkeznek. }\end{array}$ & NEM & $\begin{array}{c}\text { Hány fó? } \\
\text { (létszám) }\end{array}$ \\
\hline $\begin{array}{c}\text { Az alkalmazottak száma, } \\
\text { akik angol nyelven } \\
\text { közép- vagy felsőfokon } \\
\text { beszélnek. }\end{array}$ & & & \\
\hline $\begin{array}{c}\text { Az alkalmazottak száma, } \\
\text { akik felsőfokú } \\
\text { végzettséggel } \\
\text { rendelkeznek. }\end{array}$ & & & & \\
\hline
\end{tabular}


19.Kérem arányosítsa, hogy a projekt elvégzendő tevékenységei hány százalékban voltak elvégezve más, külső szervezet által (mint külső szolgáltatás, megbízási szerződés)!

Több mint $20 \%$

Több mint $40 \%$

Több mint $60 \%$

Több mint $80 \%$

Más:

20.A megvalósítás során észlelt problémákat az alkalmazottak oldották meg?

$\square$ Igen

$\square$ Nem

20.1 Ha IGEN, kérem, a lenti listából válasszon ki maximum 2 problémát, vagy soroljon fel olyan problémát, amit nem talál a listában, és a jobb oldali sorban fejtse ki, hogyan lett megoldva!

\begin{tabular}{|c|c|c|}
\hline Lehetséges problémák: & $\begin{array}{c}\text { Kérem, } \\
\text { jelölje } \\
\text { be! }\end{array}$ & Kérem, fejtse ki bővebben! \\
\hline Közbeszerzési kérdés & & \\
\hline $\begin{array}{l}\text { A szállítókkal/szerződő } \\
\text { cégekkel/szakértőkkel/előadókkal }\end{array}$ & & \\
\hline
\end{tabular}




\begin{tabular}{|l|l|}
\hline adódott problémák & \\
\hline Pénzügyi nehézségek & \\
\hline $\begin{array}{l}\text { Projekt célszemélyeivel való } \\
\text { kérdések }\end{array}$ & \\
\hline Elszámolással kapcsolatos kérdések & \\
\hline $\begin{array}{l}\text { A támogatási szerződéssel } \\
\text { kapcsolatos kérdések }\end{array}$ & \\
\hline $\begin{array}{l}\text { Tevékenységek megvalósításával } \\
\text { kapcsolatos kérdések }\end{array}$ & \\
\hline Partnerekkel való együttmúködés & \\
\hline Egyéb (Kérem, részletezze!): & \\
\hline
\end{tabular}

21. Az elmúlt három évben alkalmazottai összesen hány képzésben/tréningen vettek részt?

Több mint 2

$\square$ Több mint 5

$\square$ Kevesebb, mint 2

$\square$ Más:

21.1 Milyen képzésben vettek részt? 
22. A következő kijelentések közül melyikkel ért egyet és melyikkel nem?

\begin{tabular}{|c|c|c|c|}
\hline Kijelentés & Egyetértek & $\begin{array}{c}\text { Nem értek } \\
\text { egyet }\end{array}$ & $\begin{array}{c}\text { Nem } \\
\text { válaszolo } \\
\mathbf{k}\end{array}$ \\
\hline $\begin{array}{c}\text { A pályázatok elkészítésébe mindig be kell } \\
\text { vonni a szervezet szakértőit. }\end{array}$ & & & \\
\hline $\begin{array}{l}\text { Az alkalmazottak aktívan segítik a pályázat } \\
\text { megvalósítását. }\end{array}$ & & & \\
\hline $\begin{array}{l}\text { A szervezetünk alkalmazottai sok új } \\
\text { információt és eljárást tanultak a lezárt } \\
\text { pályázatból a partner szervezet } \\
\text { alkalmazottaitól. }\end{array}$ & & & \\
\hline $\begin{array}{l}\text { A szervezetünk dolgozói jelenleg is } \\
\text { kapcsolatban vannak a partner szervezet } \\
\text { dolgozóival. }\end{array}$ & & & \\
\hline $\begin{array}{l}\text { A megvalósított pályázat elősegítette az } \\
\text { intézményi teljesítmény növekedését. }\end{array}$ & & & \\
\hline
\end{tabular}

23. A lezárult pályázat után milyen változásokat észlelt a humánerőforrás terén? 
24. Ezek a változások hogyan befolyásolták a jövőbeli pályázatokat (ha voltak más pályázatok a későbbiekben)?

25. Kérem, jelölje meg, hogy Ön szerint a képzettség tekintetében mely területeken szorulnak az Ön alkalmazottai/munkatársai leginkább felzárkóztatásra (1: elengedhetetlen a képzés a további fejlödés szempontjából; 5: megfelelö a képzettség, csak az új információk átadása szükséges)! Kérjük, válaszát egyértelmüen jelölje.
Projektmenedzsment
$\begin{array}{lllll}1 & 2 & 3 & 4 & 5\end{array}$
Vidékfejlesztés
$\begin{array}{lllll}1 & 2 & 3 & 4 & 5\end{array}$
$\square$ Humánerőforrás menedzsment
$\begin{array}{lllll}1 & 2 & 3 & 4 & 5\end{array}$

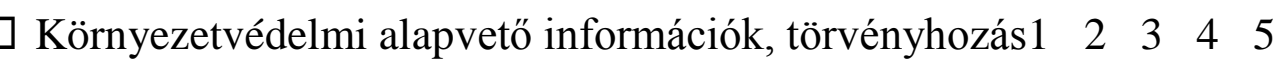
Stratégiák elkészítése - stratégiai tervezés
$\begin{array}{lllll}1 & 2 & 3 & 4 & 5\end{array}$
Helyi termékek - marketing
$\begin{array}{lllll}1 & 2 & 3 & 4 & 5\end{array}$
Közbeszerzési eljárások
$\begin{array}{lllll}1 & 2 & 3 & 4 & 5\end{array}$
$\square$ Helyi önkormányzatokkal szorosan együttműködő gazdasági szereplők $\begin{array}{llllll}\text { képzés } & 1 & 2 & 3 & 4 & 5\end{array}$
$\square$ Más: 


\section{$\underline{\text { A válaszadó adatai }}$}

Település:

Megye:

A kitöltő intézmény/hálózat/szervezet/helyi közösség megnevezése:

Neme (aláhúzandó): férfi nő

Kora (aláhúzandó): $\quad 25$ év alatt $\quad 26-40$ év között $\quad 40$ év felett

Végzettsége (aláhúzandó): alapfokú középfokú felsőfokú

Munkahelye (aláhúzandó): közszféra civil szféra üzleti szféra

A szervezet tevékenységi területe: .............................. 


\section{2. számú melléklet: A kutatás keretében végzett célcsoportos lekérdezés kérdőíve}

1.Kérem, mesélje el röviden, miröl szólt a pályázat, amiben részt vett!

2.Kérem, mondjon pár szót a partnerszervezetröl (a szervezet neve, tevékenységei, illetve bármi, amire emlékszik a magyar/román szervezettel kapcsolatban)!

3.A következö kijelentések közül melyikkel ért egyet és melyikkel nem?

\begin{tabular}{|c|c|c|c|}
\hline Kijelentés & IGEN & NEM & $\begin{array}{c}\text { Nem } \\
\text { válaszolok }\end{array}$ \\
\hline $\begin{array}{c}\text { A pályázatban számos új információt } \\
\text { kaptam. }\end{array}$ & & \\
\hline $\begin{array}{c}\text { Jelenleg is kapcsolatban állok a pályázat } \\
\text { magyar/román partnereivel, a célcsoportból } \\
\text { személyekkel stb. }\end{array}$ & & & \\
\hline $\begin{array}{c}\text { A pályázatban megszerzett információkat } \\
\text { munkatársaimmal/családommal/ismerősei } \\
\text { mmel (húzza alá a megfelelőt - akár többet } \\
\text { is - és jelölje). }\end{array}$ & & & \\
\hline
\end{tabular}


4. Ön szerint milyen arányban ismerték a helyi lakosok a pályázat eredményeit és tevékenységeit?

$\square$ Kevesebb, mint $10 \%$ a lakosságnak

Több mint $20 \%$ a lakosságnak

$\square$ Több mint $30 \%$ a lakosságnak

$\square$ Több mint $40 \%$ a lakosságnak

$\square$ Más:

5.Összesen hány pályázati találkozón vett részt a megvalósitás idején és hányban a pályázat után?

A pályázat idején: __ találkozó

A pályázat után:___ találkozó

6. Kérem, értékelje az alábbi kijelentést!

"'A pályázatban megfogalmazott célkitüzések és célok...."

\begin{tabular}{|c|c|c|c|c|}
\hline $\begin{array}{c}\text { Egyáltalán nem } \\
\text { érdekeltek }\end{array}$ & $\begin{array}{c}\text { Nem } \\
\text { érdekeltek }\end{array}$ & $\begin{array}{c}\text { Érdekeltek is, } \\
\text { meg nem is }\end{array}$ & $\begin{array}{c}\text { Érdekelt } \\
\text { ek }\end{array}$ & $\begin{array}{c}\text { Nagyon } \\
\text { érdekeltek }\end{array}$ \\
\hline 1 & 2 & 3 & 4 & 5 \\
\hline
\end{tabular}


7. Kérem, értékelje az alábbi kijelentést!

"'A pályázat tevékenységei, amelyekben részt vettem...."

\begin{tabular}{|c|c|c|c|c|}
\hline $\begin{array}{c}\text { Egyáltalán nem } \\
\text { érdekeltek }\end{array}$ & $\begin{array}{c}\text { Nem } \\
\text { érdekeltek }\end{array}$ & $\begin{array}{c}\text { Érdekeltek } \\
\text { is, meg nem } \\
\text { is }\end{array}$ & $\begin{array}{c}\text { Érdekelte } \\
\mathbf{k}\end{array}$ & $\begin{array}{c}\text { Nagyon } \\
\text { érdekelte } \\
\mathbf{k}\end{array}$ \\
\hline 1 & 2 & 3 & 4 & 5 \\
\hline
\end{tabular}

8. Kérem, értékelje az alábbi kijelentést!

"'A pályázatban elsajátított információk számomra...."

\begin{tabular}{|c|c|c|c|c|}
\hline $\begin{array}{c}\text { Egyáltalán nem } \\
\text { érdekeltek }\end{array}$ & $\begin{array}{c}\text { Nem } \\
\text { érdekeltek }\end{array}$ & $\begin{array}{c}\text { Érdekeltek is, } \\
\text { meg nem is }\end{array}$ & $\begin{array}{c}\text { Érdekelt } \\
\text { ek }\end{array}$ & $\begin{array}{c}\text { Nagyon } \\
\text { érdekeltek }\end{array}$ \\
\hline 1 & 2 & 3 & 4 & 5 \\
\hline
\end{tabular}

9. Kérem, értékelje az alábbi kijelentést!

"'A pályázat eredményei a szervezet/közösség számara..."

\begin{tabular}{|c|c|c|c|c|}
\hline $\begin{array}{c}\text { Egyáltalán nem } \\
\text { érdekeltek }\end{array}$ & $\begin{array}{c}\text { Nem } \\
\text { érdekeltek }\end{array}$ & $\begin{array}{c}\text { Érdekeltek } \\
\text { is, meg nem } \\
\text { is }\end{array}$ & $\begin{array}{c}\text { Érdekelte } \\
\mathbf{k}\end{array}$ & $\begin{array}{c}\text { Nagyon } \\
\text { érdekelte } \\
\mathbf{k}\end{array}$ \\
\hline 1 & 2 & 3 & 4 & 5 \\
\hline
\end{tabular}


10. Kérem, értékelje az alábbi kijelentést!

"'A lakosság/szervezeti munkacsoport a pályázati eredményeket..."

\begin{tabular}{|c|c|c|c|c|}
\hline $\begin{array}{c}\text { Egyáltalán nem } \\
\text { érdekeltek }\end{array}$ & $\begin{array}{c}\text { Nem } \\
\text { érdekeltek }\end{array}$ & $\begin{array}{c}\text { Érdekeltek } \\
\text { is, meg nem } \\
\text { is }\end{array}$ & $\begin{array}{c}\text { Érdekelte } \\
\mathbf{k}\end{array}$ & $\begin{array}{c}\text { Nagyon } \\
\text { érdekeltek }\end{array}$ \\
\hline 1 & 2 & 3 & 4 & 5 \\
\hline
\end{tabular}




\section{3.melléklet: A Civil Klaszternek javasolt együttmüködési megállapodás (minta)}

Amely létrejött a Civil Klaszterben együttmüködő felek (továbbiakban Felek) között a mai napon az alábbi feltételekkel:

\section{Elözmények}

Az akciókutatás keretében létrejött egy olyan együttmüködés, kezdeményezés melynek számos civil szervezet tagja. A partnerek célja a továbbiakban is, hogy a szinergia hatások kihasználásával, vagyis egy komplex, interregionális, a helyi tapasztalatokon és együttmüködésen alapuló lehetőségekkel a partnerek a térség fejlesztését érjék el.

A Klaszter létrehozásának előzményei: az akciókutatás során elkészültek az érintett magyar és román határtérség civil kataszterei, illetve egy pályázati adatlap és olyan dokumentumok, amelyek a létrehozandó szervezeti hálózat céljáról, stratégiájáról menedzselésének, finanszírozásának, továbbfejlesztésének meghatározásáról szóltnak. 2012-ben megrendezésre került a Civil Klaszter létrehozása céljából a nyitó ülés, ahol a résztvevők megállapodtak jelen Együttmüködési megállapodás, illetve az éves munkaterv tartalmáról. 


\section{A megállapodás célja}

A Felek megállapodnak abban, hogy kölcsönösen együttműködve és az Éves Munkatervben meghatározottakat megvalósítva létre kívánnak hozni és működtetni egy Klasztert, amely hozzájárul a résztvevő szervezetek müködésük során megfogalmazott rövid, valamint hosszú távú célok megvalósításához.

A Klaszter nyitott szervezet a térséghez, valamint az egyes célterületekhez kötődő civil szervezetek, gazdasági társaságok és azok meglévő együttmüködései számára. Alapító tagoknak azon szervezetek minősülnek, amelyek jelen Együttmüködési megállapodást aláírták.

Ezt követően a Felek lehetővé teszik, hogy az általuk későbbiekben meghatározni kívánt feltételeknek megfelelö szervezetek csatlakozhassanak jelen klaszter kezdeményezéshez és annak munkájában részt vehessenek.

A Felek kijelentik, hogy a Klaszter és céljainak megvalósítása során a tagok egységként müködnek együtt az egyes autonómiák tiszteletben tartása mellett.

\section{A Felek jogai és kötelezettségei}

- A Felek jogosultak részt venni a Civil Klaszter előszervezési, létrehozatali, stratégia alkotói tevékenységében, majdani programjaiban;

- A Felek együttesen, illetve a későbbiekben a kinevezett Klasztermenedzsment szervezet keretein belül jogosultak dönteni a Civil Klaszter alapítói kérdéseiben és továbbfejlesztési lépéseiben a szakmai és területi arányok figyelembevételével;

- A Felek részt vesznek a Civil Klaszteren belüli fejlesztési projektjavaslatok kidolgozásában, elősegítik az együttmúködés nyújtotta innovációs tevékenységeket; 
- A Felek kinyilvánítják, hogy a későbbiekben elkészülő Szervezeti és Müködési Szabályzatban foglaltak szerint, de legalább évente egyszer információt szolgáltatnak a tevékenységükről, terveikről egymásnak;

- A Felek integrátorként segítik és bevonják a környezetükben müködő és a Civil Klaszter céljait elfogadó szervezeteket;

- A Felek a közös feladatok finanszírozásában az ésszerüség és az arányosság szem elött tartásával részt vállalnak.

- A Felek részt vesznek a Civil Klaszter alapdokumentumainak kidolgozásában, elfogadásában, valamint az azokban vállalt kötelezettségeiknek eleget tesznek.

\section{A klaszter irányító/koordináló testületének kinevezése}

A Felek a 2012-ben megszervezett nyitó ülésen a jelen Együttmüködési Megállapodásban foglaltak teljesítése érdekében koordináló testületet választottak, amelynek tagjai az Alapítók részéről a következők:

A klaszter irányító testülete a Civil Klaszter menedzsment szervezetének kijelöléséig ellátja az operatív döntéshozatallal kapcsolatos, illetve az éves munkatervben meghatározott feladatokat, amelyekkel a Felek megbízzák őket. Az irányító testület tagjainak száma és személye a Felek együttes döntésével módosítható.

\section{A megállapodás hatályba lépése és időtartama}

Jelen Együttmüködési megállapodás a Felek aláírásával az aláírás napján lép hatályba és határozatlan ideig érvényes. 


\section{Egyéb rendelkezések}

- A Felek megállapodnak abban, hogy a jelen Együttműködési megállapodásban meghatározott kötelezettségeik teljesítése érdekében, szükség szerint konzultációkat tartanak.

- A Felek megállapodnak abban, hogy a jelen Együttmüködési megállapodásban foglaltak teljesítését legalább negyedévente értékelik, és határoznak a további teendőkröl.

Alulírott Felek ezen Együttmüködési megállapodást, mint akaratunkkal mindenben megegyezőt, közös átolvasás és értelmezés után írtuk alá. 


\section{4. számú melléklet: Javasolt projekt adatlapok a Civil Klaszter és az Európa- kapu ETT tevékenységeinek támogatására}

\section{Projekt címe és leírása: Nemzetközi Civil Klaszter a Duna Régió területén}

A projekt keretében olyan tevékenységekre kerül sor, amelyek a Duna Régióban erősíthetik a határon átnyúló, és az itt élő nemzetek közötti együttmüködést.

Az "Érmelléki Értéklánc” Klaszter az Európa-kapu ETT területén müködő civil szervezetek szövetsége, amelyet az Alapítók a Klaszter formális szervezetének létrehozását célzó Együttmüködési Megállapodás aláíásával alapítottak meg 2012. február 24-én.

A Klaszter létrehozásának előzményei: a kutatás során elkészültek az érintett magyar és román határtérség civil adatbázisai, illetve a Civil Klaszter Hálózati Stratégiája (továbbiakban: stratégia), amely a létrehozandó szervezeti hálózat céljáról, stratégiájáról, valamint menedzselésének, finanszírozásának és továbbfejlesztésének meghatározásáról szól. 2012. március 10-én Székelyhídon került megrendezésre a Civil Klaszter létrehozása céljából a Nyitó ülés, ahol a résztvevők megállapodtak az Együttműködési Megállapodás, illetve az éves munkaterv tartalmáról.

\section{Pályázat indoklása}

Számos helyen szokták hangoztatni azt a kijelentést, hogy a fiatalok a jövő nemzedéke. Ök azok, akik építik a közös jövőnket. Az Európa-kapu ETT egyik célkitüzése a határon túli magyar szervezetekkel való együttmüködés. Mivel térségünkben (Nyírség és Érmellék) számos civil szervezet van, jelen pályázat 
keretében szeretnénk feltérképezni a határon túli civil szervezeteket (az érmelléki egyesületeket és alapítványokat), melyek célcsoportja a térségben élő fiatalok. Mindkét térség legfőbb problémája a fiatalok elvándorlása, ugyanis a nagyvárosok, mint Debrecen, Nagyvárad vagy Kolozsvár olyan lehetőségeket nyújtanak a fiataloknak, melyeket a saját településeiken nem találnak meg.

A térség gazdasági szerepének növekedéséhez nem csak a nemzeti és helyi közigazgatási hatóságok tudnak hozzájárulni, hanem a civil szervezetek is. Ennek érdekében szeretnénk egy olyan müködő ifjúsági hálózatot létrehozni, amely képes a határon átnyúló pályázatok feltételeinek megfelelni és akár nemzetközi együttmüködési pályázatokban is képes vetélkedni az Európai Unió régi tagállamaiból származó civil szervezeteivel. Jelenleg folyamatban van egy magyar-román ifjúsági civil háló fejlesztése, és célunk az, hogy ezen modell alapján hozzuk létre a Duna Régió civil hálózatát.

A térségre jellemző, hogy több civil szervezet van, viszont intézményi kapacitásuk alacsony. Ennek érdekében javaslunk egy olyan civil hálót létrehozni, amely - mint intézményi forma ifjúsági civil klaszter - megfelelö intézményi keretet nyújt a jövőbeli fejlesztésekhez.

Az intézményi kapacitás alatt azt értjük, hogy az ifjúsági civil szervezetek főként helyi kezdeményezéseket tudnak megvalósítani, mivel nem képesek Európai Uniós nagy pályázatok megvalósítására. Ennek oka fóként az információ és a megfelelő partner hiánya. Erre a problémára jelent megoldást a civil klaszter, melyet az Európa-kapu ETT müködtetne. 


\section{A projekt javasolt tevékenységei}

\section{Négy nagy szakaszt javaslunk megvalósítani:}

a) Kutatások, stratégiai tervezés (1. tevékenység)

b) Tudásbázisok létrehozása (1. és 3. tevékenység)

c) Hálózatépités (2. és 4. tevékenység)

d) Intézmény- és projektfejlesztés (4. tevékenység)

Tevékenység 1: A Duna Régió ifjúsági civil szervezeteinek feltérképezése

Tevékenység 2: Adatbázis elkészítése a Duna Régióban tevékenykedő civil szervezetekröl

Tevékenység 3: Többnyelvü kiadványok és tanulmányok elkészítése a civil szektor Duna Régióban lévő szervezeteiröl

Tevékenység 4: A Duna Régiós civil szervezetek és fiatalok találkozója - a Civil klaszter létrehozása

\section{Célcsoport és bevont résztvevők}

Pályázatunk partnerei civil szervezetek Magyarországról, Ukrajnából, Romániából, Horvátországból, Szlovéniából, Szerbiából, Szlovákiából és Csehországból. A résztvevők főként ifjúsági szervezetek képviselői lesznek, viszont vannak olyan partnereink is, akiknek fö célja a közösségi fejlesztés, és a szervezeten belül müködtetnek ifjúsági szekciót. 
Fontos ezen szereplők találkozója, hiszen a szakmai találkozón kitérünk a közös pályázati lehetőségekre is (Magyarország-Románia-Ukrajna-Szlovákia ENPI Program, Magyarország-Románia, Magyarország-Szlovákia, MagyarországSzerbia Határon Átnyúló Együttműködési Programok, Youth in Action (Fiatalok lendületben) - nemzetközi együttmüködési prioritása, South-East Europe Délkelet-Európai Együttmüködési Program, Visegrád Alap stb.).

Tehát a pályázat nem csak egy közös, a Duna Régióban lévő hálót/klasztert hoz létre, hanem számos településen fejlesztési lehetőségeket nyit meg azáltal, hogy a civil szervezeteknek lehetőséget biztosítunk megismerni ezeket a pályázatokat, valamint közös pályázati adatlapokat generálunk.

Ezt követően a közös találkozón is partnerségi lehetőségek nyílnak meg a résztvevők elött (ebben nagy segítség lesz az online civil adatbázis is, amelyben a civil szervezetek elérhetőségei lesznek feltüntetve). Ezáltal a pályázat közvetett célcsoportja kiterjedt és magában foglalja több száz település lakosságát.

5. Költségvetés: kb. 220.000 euró (ebben a Lead Partner és a hét partner szakmai tevékenységeinek költségei, valamint az utazások és kiküldetések költségei lettek betervezve).

Kb. évi 40.000 euró müködési költség (a Duna Régió civil klaszter szakmai vezetése, irányítása Magyarországon lenne, Nyíradonyban). 
A projekt címe: Integrált mezögazdasági pályázat az Európa-kapu ETT terïletén

\section{Lehetséges támogatási forrás:}

Magyarország-Románia Határon Átnyúló Együttmüködési Program (20142020)

\section{A projekt indokoltsága:}

A mezőgazdaság és a mezőgazdasági termékek feldolgozása fontos és

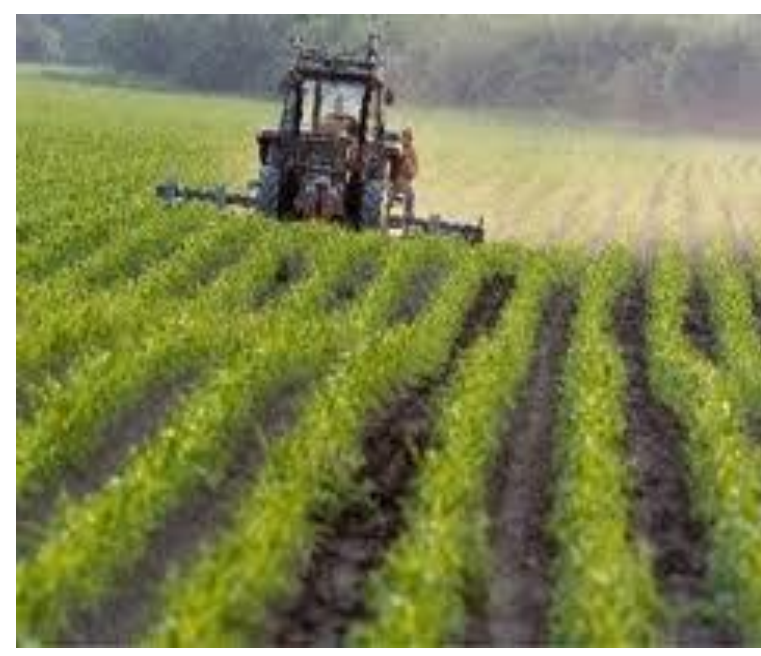
meghatározó volt a térség iparágai között. Jelenleg a térségben magas a munkanélküliség, valamint a mezőgazdaságban és a mezőgazdasági termékeket feldolgozó iparban tevékenykedők száma alacsony. Az Ötödik Kohéziós Jelentés említést tesz az intézményi kapacitásról is. A Jelentés szerint a megfelelő intézményi keretek (fóként a hatékony közigazgatásra és közszolgáltatásokra utal a Jelentés) megteremtik a versenyképességhez és növekedéshez szükséges feltételeket.

A Jelentés egyik része kitér az agrárpolitikára is. A dokumentum szerint az Európai Uniós területi támogatásoknak biztosítaniuk kell a mezőgazdaságban a stabil agrártermelést. Az Európa-kapu EGTC térségében a mezőgazdaság mindig is fontos szerepet töltött be és számos termelő és feldolgozó van a térségben.

Az érmelléki és a nyírségi gyümölcs (főként a szőlö) és a zöldségtermelés mindig is húzóágazata volt a térségnek. Az utóbbi két évtizedben azonban a kis 
területeken történő mezőgazdasági tevékenység vált jellemzővé a térségben,és egyre jobban a mezőgazdaság csak mint kiegészítő foglalkozás és jövedelemforrás jelenik meg a vidéki emberek életében. Egy másik fontos tényező, hogy a megtermelt termékek tárolása, értékesítése és feldolgozása nincs térségi szinten megszervezve.

Nem léteznek egységes elvárások a felvásárlók felé a termelőkkel szemben és nem létezne egységes, minőségileg megegyező termékek sem. Elmondható tehát, hogy a térségben számos lehetőség rejlik a mezőgazdaságban, viszont fontos volna a mezőgazdaságban dolgozókat összefogni és a közös fejlődést segíteni.

\section{A projekt célja:}

Az integrált mezőgazdasági projekt célja elsődlegesen az ETT területén lévő agrárkultúra és az agrártermékeket feldolgozó iparág fennmaradásának biztosítása. Ezzel párhuzamosan véleményünk szerint fontos az agrárium versenyképességének megerősítése.

\section{Célcsoport:}

Közvetlen célcsoport

- Az ETT településéiről összesen: kb. 80 gazdálkodó, feldolgozó és értékesítő stb.

Közvetett célcsoport

- Az érintett települések lakossága 


\section{Projektek leírása}

\subsection{Térségi időjárás előrejelzési rendszer}

A projekt keretében több tevékenység kerül megvalósításra. Először is szeretnénk a termelők figyelmét felhívni a várható klímaváltozásra.

Egy olyan integrált területi rendszert szeretnénk létrehozni, amely hosszabb időszakokra képes előre jelezni a várható időjárási változásokat, melyek akár az

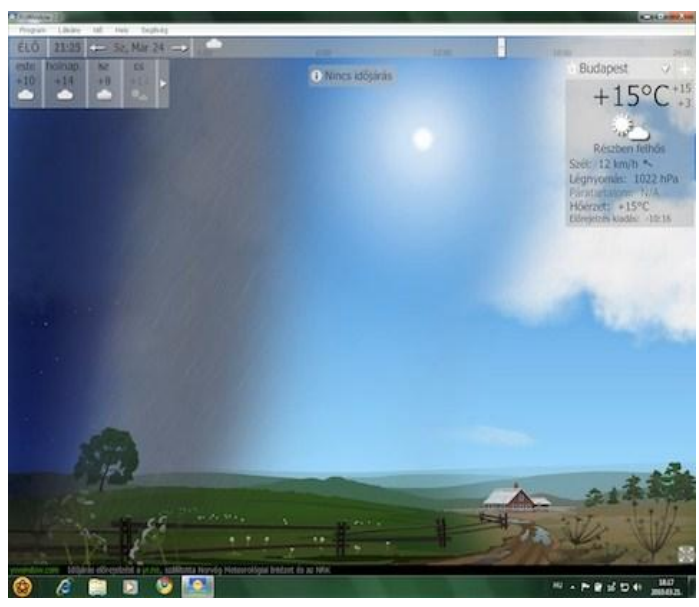
egész évi termést is veszélyeztethetik. A rendszer beüzemelését követően a térségben élő gazdák, termelők értesítést kapnának a várható időjárási változásokról.

A rendszer kialakítását alátámasztja az utóbbi években érzékelhető éghajlat- és klímaváltozás is. Az utóbbi pár évben a tavasz és az ősz sokkal rövidebb volt, míg a nyári heves viharok, a zivatarok vagy éppen a nem várt nagy aszály, szárazság és esőmentes időszak olyan károkat okoztak, amelyek visszafordíthatatlan hatással voltak a gazdálkodók éves termésére. A rendszer kialakítási költségeinek nagy része lehívható az Európai Területi Együttmüködési Program magyar-román együttmüködést támogató keretéböl. 
A rendszer egyszerü logikája a következő ábrán látható:

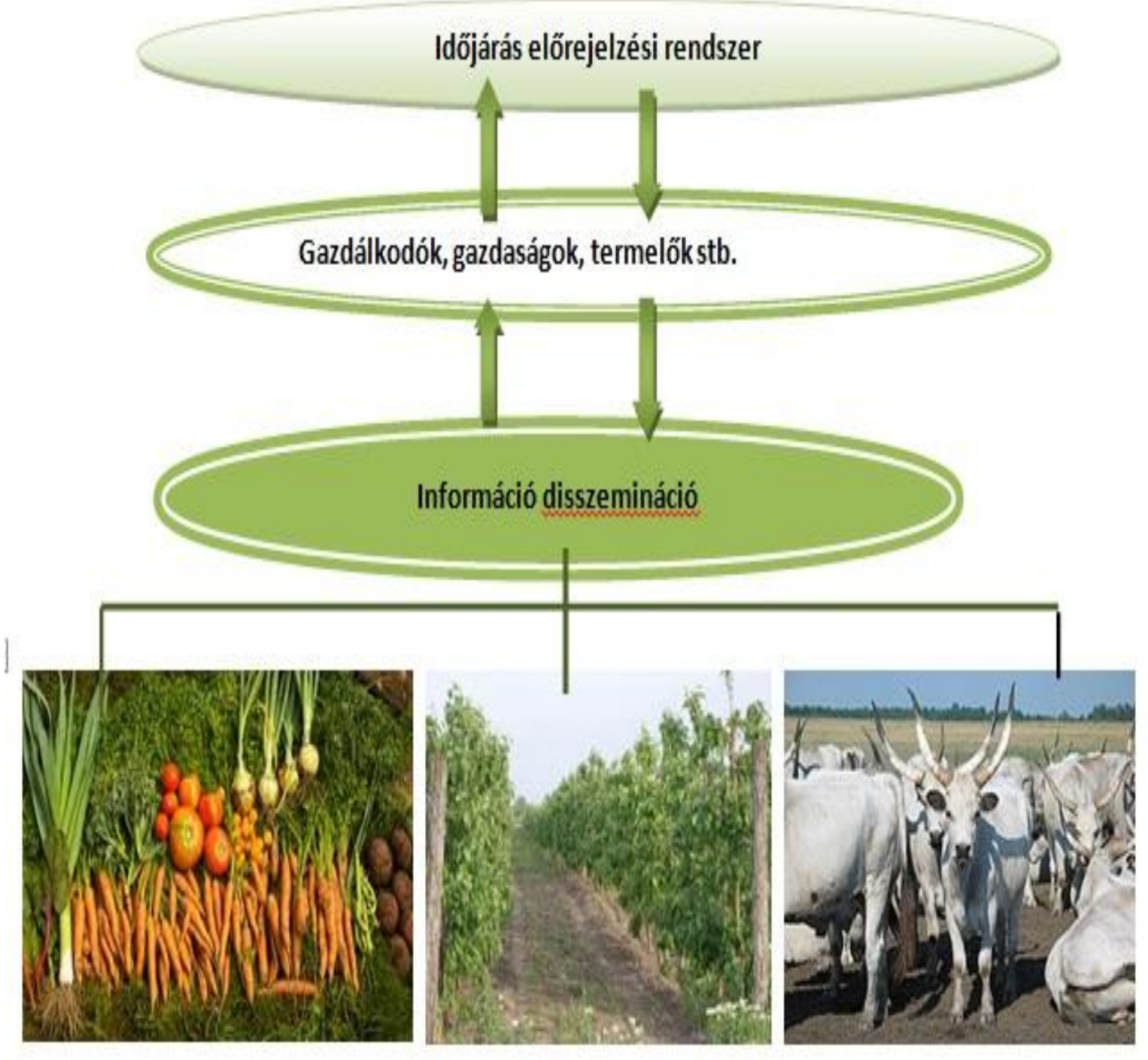

14.ábra: Az információ áramlása az időjárás elörejelzési rendszerben (saját szerkesztés) 


\subsection{Kontroll labor (termék- és talajvizsgálat)}

A térségre jellemző probléma, hogy csak a nagyvárosokban (Debrecen, Nyíregyháza, Szatmárnémeti és Nagykároly) lehetséges a megtermelt és elóállított termékek, valamint a talaj vizsgálatának elvégzése. Ez több problémát is okozhat, hiszen a termelőnek utaznia kell azért, hogy a vizsgálatokat elvégeztesse, ezáltal az eredmény később születik meg. Ezen tényezők pedig befolyásolják a gazda/termelö/feldolgozó napi szintü munkáját.

A létrehozandó rendszer - egy mobil kontroll labor - egyszerúen és gyorsan tudja segíteni a gazdák/termelők munkáját. A mobil laborban egyes vizsgálatok akár helyben is elkészülhetnek, míg bizonyos vizsgálatok mintáit a mobil labor be tudná gyüjteni, majd az eredményről értesítené a gazdát/termelőt.
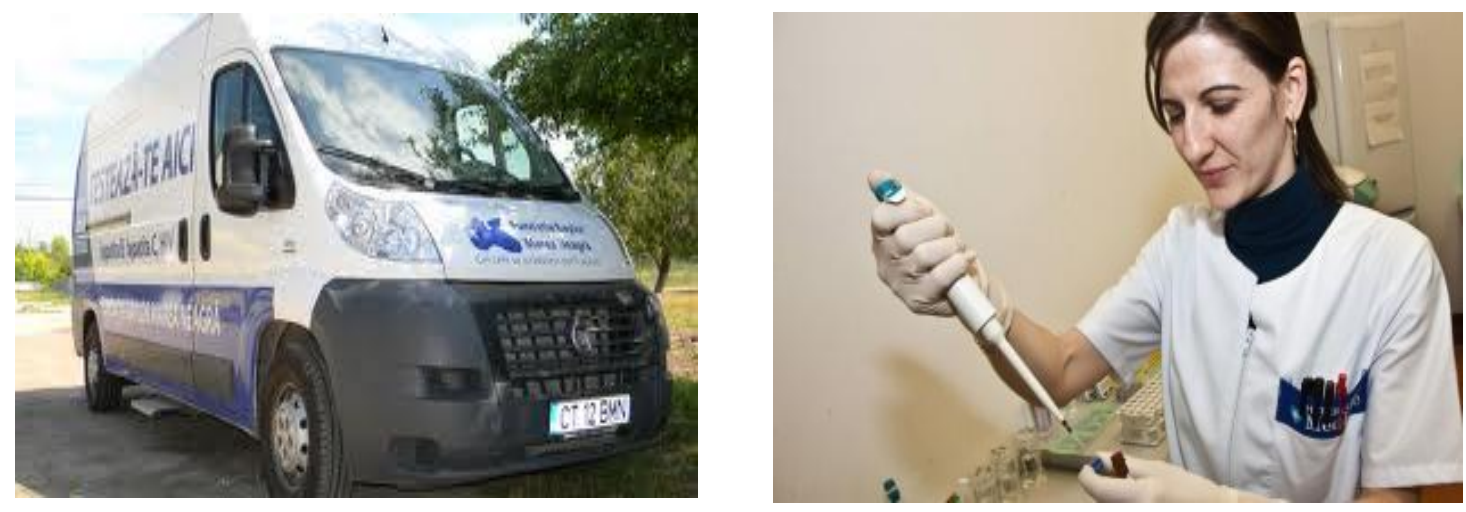

A mobil labor előnyei:

helyben gyüjtené össze a mintákat és egyes vizsgálatok eredményeit akár helyben is megadná

alacsony költségü vizsgálatokat/szolgáltatást tudna nyújtani helyben 
egy jól kialakított és megszervezett program keretében meghatározott időközönként lenne elérhető a szolgáltatás minden településen (a mobil kontroll labor minden nap járná a térséget, ezáltal elérhető lenne minden érdekelt részére)

\subsection{Inkubátorház létrehozása}

Mivel fontosnak tartjuk, hogy a térségben mezőgazdasággal, feldolgozással, állatneveléssel foglalkozók megfelelő szakmai tanácsadásban és oktatásban részesüljenek, ezért szeretnénk létrehozni egy olyan központot - inkubátorházat , ahol a mezőgazdaságban dolgozók több területen is szolgáltatásokat vehetnek igénybe.

Az inkubátorház az alábbi szolgáltatásokat fogja nyújtani:

marketing tanácsadás

jogi tanácsadás

fordítás, tolmácsolás

konferenciaterem és tárgyalóterem használata

rendezvényszervezési szolgáltatások biztosítása

pénzügyi tanácsadás

Az inkubátorház egyik fő tevékenysége, hogy a mezőgazdaságban, feldolgozásban, valamint az értékesítésben érdekelt magyar és román partnereinek a tevékenységeit összehangolja, ugyanis fontos elősegíteni a közös együttmüködést. 
A térségben dolgozóknak arra kell törekedniük, hogy a térségben az általuk megtermelt termékeket fogyasszák a helyi boltokban, vendéglőkben, szállodákban, panziókban, iskolákban és óvodákban. Ennek érdekében az inkubátorház egyik fő tevékenysége az, hogy a térségben élőket arra ösztönözze, hogy a helyi és térségi termékeket fogyasszák.

A térségben tehát egyensúlyt kell találni a kereslet és a termelés között, és meg kell teremteni a kapcsolatot a termelök és a vásárlók között annak érdekében, hogy a térségben fogyasztásra kerülő minden élelmiszer és termék a térségben legyen megtermelve.

Az inkubátorház szerepe a következő ábrán összegezhető:

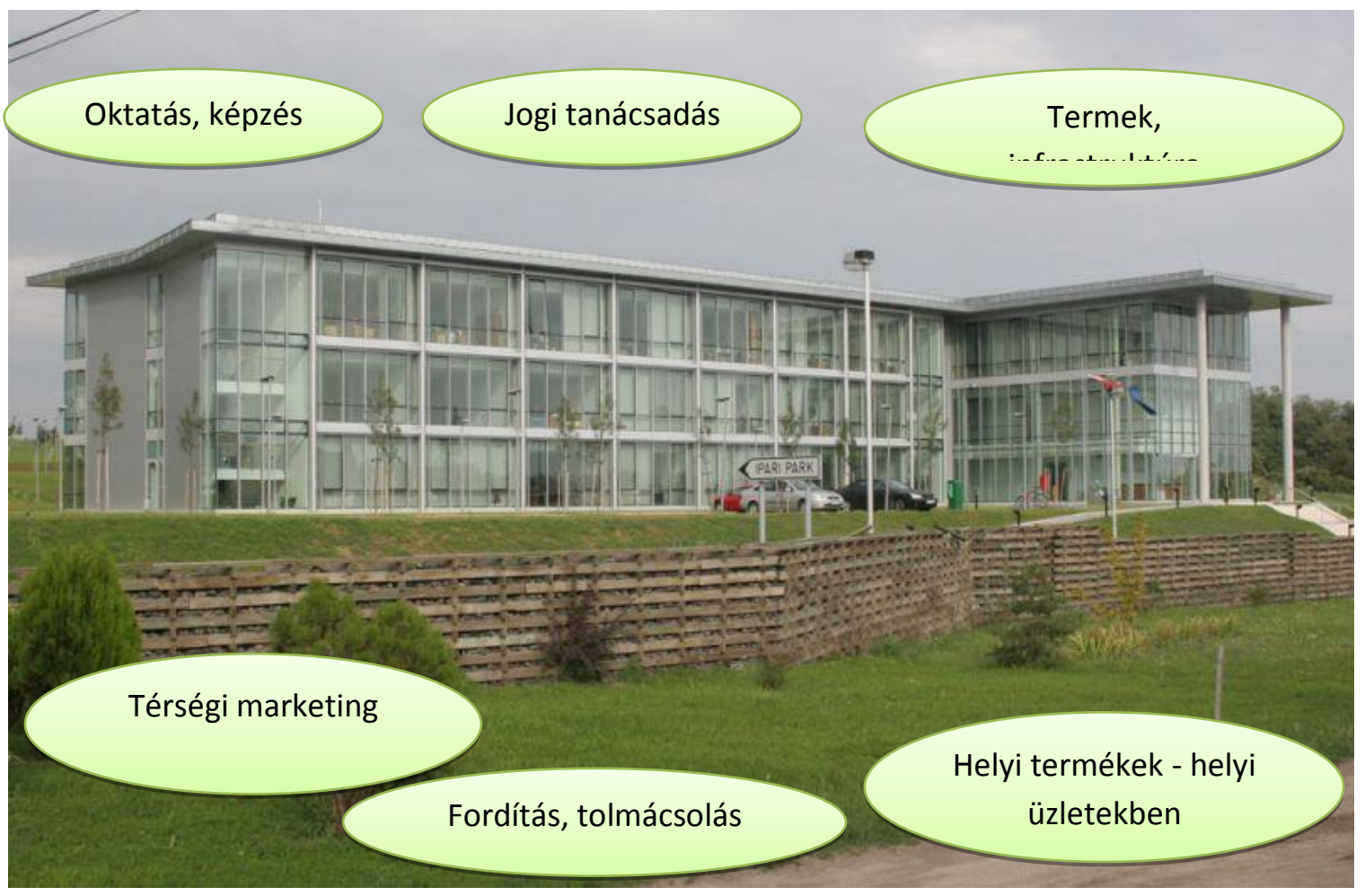

15.ábra: A javasolt létrehozandó inkubátorház szerepe (saját szerkesztés) 
Az inkubátorház tehát a mezőgazdaságban dolgozóknak nyújt megfelelő szolgáltatásokat és új lehetőségeket. Emellett adminisztratív segítséget is nyújt számukra, ugyanis a központban elérhetőek lesznek olyan egyszerü szolgáltatások, mint például a fénymásolás, nyomtatás, dokumentumok és stratégiák készítése, szakmai és marketing anyagok elkészítése. 